University of Windsor

Scholarship at UWindsor

\title{
Effect of hydraulic retention time and attachment media on sulfide production by sulfate-reducing bacteria.
}

\author{
Beatriz Carolina. Polo-Christy \\ University of Windsor
}

Follow this and additional works at: https://scholar.uwindsor.ca/etd

\section{Recommended Citation \\ Polo-Christy, Beatriz Carolina., "Effect of hydraulic retention time and attachment media on sulfide production by sulfate-reducing bacteria." (2001). Electronic Theses and Dissertations. 1820. \\ https://scholar.uwindsor.ca/etd/1820}

This online database contains the full-text of PhD dissertations and Masters' theses of University of Windsor students from 1954 forward. These documents are made available for personal study and research purposes only, in accordance with the Canadian Copyright Act and the Creative Commons license-CC BY-NC-ND (Attribution, Non-Commercial, No Derivative Works). Under this license, works must always be attributed to the copyright holder (original author), cannot be used for any commercial purposes, and may not be altered. Any other use would require the permission of the copyright holder. Students may inquire about withdrawing their dissertation and/or thesis from this database. For additional inquiries, please contact the repository administrator via email (scholarship@uwindsor.ca) or by telephone at 519-253-3000ext. 3208. 


\section{INFORMATION TO USERS}

This manuscript has been reproduced from the microfilm master. UMI films the text directly from the original or copy submitted. Thus, some thesis and dissertation copies are in typewriter face, while others may be from any type of computer printer.

The quality of this reproduction is dependent upon the quality of the copy submitted. Broken or indistinct print, colored or poor quality illustrations and photographs, print bleedthrough, substandard margins, and improper alignment can adversely affect reproduction.

In the unlikely event that the author did not send UMI a complete manuscript and there are missing pages, these will be noted. Also, if unauthorized copyright material had to be removed, a note will indicate the deletion.

Oversize materials (e.g., maps, drawings, charts) are reproduced by sectioning the original, beginning at the upper left-hand comer and continuing from left to right in equal sections with small overlaps.

Photographs included in the original manuscript have been reproduced xerographically in this copy. Higher quality $6^{n} \times 9^{n}$ black and white photographic prints are available for any photographs or illustrations appearing in this copy for an additional charge. Contact UMI directly to order.

ProQuest Information and Leaming 300 North Zeeb Road, Ann Arbor, MI 48106-1346 USA B00-521-0600

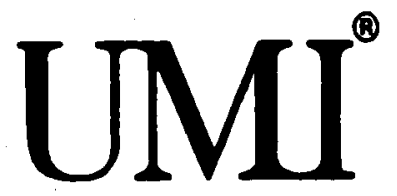


NOTE TO USERS

This reproduction is the best copy available.

UMI 


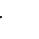




\title{
EFFECT OF HYDRAULIC RETENTION TIME AND ATTACHMENT MEDLA ON SULFWE PRODUCTION BY SULFATE REDUCING BACTERIA
}

\author{
by \\ Beatriz Carolina Polo Christy \\ B.A.Sc.
}

A Thesis Submitted to the

Faculty of Graduate Studies and Research through Civil \& Environmental Engineering in Partial Fulfillment of the Requirements for the Degree of Master of Applied Science at the University of Windsor

Windsor, Ontario, Canada 2001 (C) 2001 Beatriz Carolina Polo Christy 
National Library of Canada

Acquisitions and Bibliographic Services

395 Wellington Street OHawa ON K1A ONA Canada
Bibliotheque nationale du Canada

Acquisitions et senvices bibliographiques

395, rue Wellington Ottawa ON K1A ONA Canada
The author has granted a nonexclusive licence allowing the National Library of Canada to reproduce, loan, distribute or sell copies of this thesis in microform, paper or electronic formats.

The author retains ownership of the copyright in this thesis. Neither the thesis nor substantial extracts from it may be printed or otherwise reproduced without the author's permission.
L'auteur a accordé une licence non exclusive permettant à la Bibliothèque nationale du Canada de reproduire, prêter, distribuer ou vendre des copies de cette thèse sous la forme de microfiche/film, de reproduction sur papier ou sur format électronique.

L'auteur conserve la propriété du droit d'auteur qui protège cette thèse. Ni la thèse ni des extraits substantiels de celle-ci ne doivent être imprimés ou autrement reproduits sans son autorisation.

\section{Canadä}




\begin{abstract}
The effects of hydraulic retention time and attachment media on the rate of microbial sulfate reduction with lactate as carbon and energy source were investigated for sulfate reducing bacteria, SRB. The lactate to sulfate ratio was maintained below 2 for proper SRB activity. The Th.O.D.:N:P was kept at 100:5:1. The presence of cations, such as $\mathrm{Na}^{-}$ and $\mathrm{Mg}^{2+}$, below non-toxic concentrations was important to avoid any growth inhibition of SRB.
\end{abstract}

Batch anaerobic reactors were used in order to determine the stoichiometry of the biochemical reactions. Results indicated that $70 \%$ of the lactate fed was bio-oxidized and $30 \%$ was bio-synthesized, which showed that the energy production reaction predominated over the synthesis reaction in non-packed reactors.

Continuous mode operation of three upflow anaerobic suspended growth reactors yielded effluent sulfide concentrations as high as $190 \mathrm{mg} \mathrm{S} / \mathrm{L}$ at the optimum conditions of $20 \mathrm{~h}$ of HRT, $1.5 \mathrm{~m} / \mathrm{d}$ of upflow velocity and $6 \mathrm{~kg} / \mathrm{d} / \mathrm{m}^{3}$ of OLR, regardless of the presence of attachment media in the reactor. The critical HRT was $10 \mathrm{~h}$, which provided an upward velocity of $3 \mathrm{~m} / \mathrm{d}$. Lower retention times showed a significant decrease in the effluent sulfide concentration and washout of biomass. Doubling the OLR increased proportionally the rate of sulfide production. The effluent $\mathrm{pH}$ ranged between 6.5 and 7.0. The ORP values were below $-150 \mathrm{mV}$ which indicated sulfide production and activity of SRB. 
The substrate utilization rate constant, $k$, equal to $\mu / Y$, was $2.53 h^{-1}$ on an average at $20 \mathrm{~h}$ of HRT and was obtained through the kinetic model developed for the continuous mode operation of upflow anaerobic reactors as a plug flow type.

Visual observation revealed the presence of settled biomass at the bottom. Therefore, major sulfide production occurred within the first $300 \mathrm{~mm}$ of the reactors' height. Using the equations developed in previous studies for metal applications, this active height of $300 \mathrm{~mm}$ would allow $100 \%$ removal of the heavy metal applied at influent concentrations of $48 \mathrm{mg} \mathrm{Cr} / \mathrm{L}, 95 \mathrm{mg} \mathrm{Cu} / \mathrm{L}, 90 \mathrm{mg} \mathrm{Ni} / \mathrm{L}, 88 \mathrm{mg} \mathrm{Zn} / \mathrm{L}, 44 \mathrm{mg} \mathrm{Cd} / \mathrm{L}$ and $29 \mathrm{mg} \mathrm{Pb} / \mathrm{L}$. 


\section{ACKNOWLEDGEMENTS}

I am thankful to God, my guide and comfort, for the gifts he has given me: strength and health to live this dream.

I would like to offer this achievement to my parents, who along my life have supported me with love, eternal patience and invaluable advice.

I wish to thank Professors J.K. Bewtra and Nihar Biswas for their continual advice, reflection of their knowledge, experience and thoughtfulness.

My gratitude is to Jian Guo $\mathrm{Li}$ for his professional advice and for all the fruitful discussions

I wish to thanh $\mathrm{m}$ s Iumily and fiends for their encouragement and help in countless ways for the completion of this project.

Financial assistance " wa furnished to the author via National Council for Science and Technology (COSACIT), an organization funded by the Mexican Government. University of Windsor operating grants from the National Science and Engineering Research Council ( ISERC) provided for materials and equipment. 


\section{NOMENCLATURE}

A

ASRB

COD

C

$\mathrm{C}_{\text {。 }}$

$\mathrm{C}_{\mathrm{s}}$

$\mathrm{C}_{\mathrm{i}}$

$\mathrm{C}_{\mathrm{e}}$

CSTR

$\mathrm{H}$

HLR

HRT

K

$\mathrm{K}^{\prime}$

k

L

M

OLR

ORP

Q

$\mathrm{S}_{\max }$ cross sectional area $\left[\mathrm{L}^{2}\right]$

acetate consuming sulfate reducing bacteria

chemical oxygen demand

sulfide concentration $\left[\mathrm{M} / \mathrm{L}^{3}\right]$

initial sulfide concentration $\left[\mathrm{M} / \mathrm{L}^{3}\right]$

steady state sulfide concentration $\left[\mathrm{M} / \mathrm{L}^{3}\right]$

influent heavy metal concentration $\left[\mathrm{M} / \mathrm{L}^{3}\right]$

effluent heavy metal concentration $\left[\mathrm{M} / \mathrm{L}^{3}\right]$

continuous (flow) stirred-tank reactor

reactor's height [L]

hydraulic loading rate $\left.\left[\mathrm{L}^{3} / \mathrm{L}^{2} / \mathrm{T}\right)\right]$

hydraulic retention time also referred to as retention time [T]

rate constant $\left[\mathrm{T}^{-1}\right]$

rate constant $\left.\left[\mathrm{L}^{3} / \mathrm{M} / \mathrm{T}\right)\right]$

substrate utilization rate constant $=\mu / \mathrm{Y}\left[\mathrm{T}^{-1}\right]$

active volume depth [L]

heavy metal

organic loading rate $\left[\mathrm{M} / \mathrm{T} / \mathrm{L}^{3}\right]$

oxidation-reduction potential

volumetric flow rate $\left[\mathrm{L}^{3} / \mathrm{T}\right]$

maximum sulfide concentration $\left[\mathrm{L}^{3} / \mathrm{T}\right]$ 


$\begin{array}{ll}\text { SRB } & \text { sulfate reducing bacteria } \\ S & \text { sulfide } \\ \text { SS } & \text { suspended solids }\left[\mathrm{M} / \mathrm{L}^{3}\right] \\ t_{d} & \text { hydraulic retention time in active volume }[\mathrm{T}] \\ \mu & \text { specific growth rate }\left[\mathrm{T}^{-1}\right] \\ \text { UA } & \text { upflow anaerobic reactor } \\ \text { UASB } & \text { upflow anaerobic sludge blanket reactor } \\ \text { UAFF } & \text { upflow anaerobic fixed film reactor } \\ \text { V } & \text { reactor's volume }\left[\mathrm{L}^{3}\right] \\ V_{0} & \text { upflow velocity }[\mathrm{L} / \mathrm{T}] \\ \text { VSS } & \text { volatile suspended solids }\left[\mathrm{M} / \mathrm{L}^{3}\right] \\ \text { Ws } & \text { molecular mass of sulfide }[\mathrm{M} / \mathrm{Mmol}] \\ \text { Wm } & \text { molecular mass of heavy metal }[\mathrm{M} / \mathrm{Mmol}] \\ X & \text { biomass concentration }\left[\mathrm{M} / \mathrm{L}^{3}\right] \\ X_{0} & \text { initial biomass concentration }\left[\mathrm{M} / \mathrm{L}^{3}\right] \\ X_{s} & \text { steady state biomass concentration }\left[\mathrm{M} / \mathrm{L}^{3}\right] \\ Y & \text { yield coefficient }[\mathrm{M} / \mathrm{M}]\end{array}$




\section{LIST OF TABLES}

3.1 Batch Substrate Composition A for Phase I 30

3.2 Batch Substrate Composition B for Phase II 32

$\begin{array}{lll}3.3 & \text { Packing Material Characteristics } & 38\end{array}$

3.4 Substrate Composition for Continuous Flow Mode 39

$3.5 \quad$ UA Reactors Operating Conditions for Phase III 44

5.1 Sulfide and VSS Mass Production for 10 L Batch Reactors along Reactor Height (New Formulation)

5.2 Mass and Electron Balances under Batch Mode for Reactor I (packed) 84

5.3 Mass and Electron Balances under Batch Mode for Reactor II (non-packed) 85

5.4 Mass and Electron Balances under Batch Mode for Reactor III $\begin{array}{ll}\text { (non-packed) } & 86\end{array}$

5.5 Average and Steady State VSS Concentrations (Set 1) 89

5.6 Average and Steady State VSS Concentrations (Set 2) 92

5.7 Average and Steady State VSS Concentrations (Set 3) 95

5.8 Average and Steady State VSS Concentrations (Set 4) 98

5.9 Average and Steady State VSS Concentrations (Set 5) 100

5.10 Summary of Steady State Sulfide and VSS Concentrations During Continuous Operation (Phase III)

5.11 Summary of the Rate of Mass Production for Sulfide and VSS During $\begin{array}{ll}\text { Continuous Operation (Phase III) } & 103\end{array}$

5.12 Calculations Model I: Biomass Production Rate $\quad 110$

5.13 Calculations Model II: Sulfide Production Rate $\quad 116$

5.14 Calculations Model III: Sulfide and Biomass Concentrations 119

6.1 Sulfide Production Rate Calculated by Different Methods 142

B. 1 Sulfide Production During Phase I (2 L Batch Reactors) 162

B.2 ORP Progression During Phase I (2 L Batch Reactors) 163 
B.3 pH Progression During Phase I (2 L Batch Reactors) 163

B.4 Sulfide Production During Phase II ( $1^{\text {st }}$ and $2^{\text {nd }}$ Sequences) $\quad 164$

B.5 ORP Progression During Phase II ( $1^{\text {st }}$ and $2^{\text {nd }}$ Sequences) 165

B.6 pH Progression During Phase II ( $1^{\text {st }}$ and $2^{\text {nd }}$ Sequences $) \quad 165$

B.7 Sulfide Production During Phase II ( $3^{\text {rd }}$ and $4^{\text {th }}$ Sequences) 166

B. 8 VSS Production During Phase II ( $3^{\text {rd }}$ and $4^{\text {th }}$ Sequences) 167

B.9 pH Progression During Phase II ( $3^{\text {rd }}$ and $4^{\text {th }}$ Sequences) 168

$\begin{array}{lll}\text { B. } 10 & \text { Sulfide Production During Phase II (Consecutive) } & 168\end{array}$

B. I l VSS Production During Phase II (Consecutive) 169

B.12 ORP Progression During Phase II (Consecutive) 169

B.13 pH Progression During Phase II (Consecutive) 169

B. I4 VSS and Sulfide Relation for Reactor I (New Substrate Formulation) 170

B. 15 VSS and Sulfide Relation for Reactor II (New Substrate Formulation) 170

B. 16 VSS and Sulfide Relation for Reactor III (New Substrate Formulation) 170

B.17 Effluent and First Port Sulfide Concentrations. Set 1

B.18 Effluent and First Port VSS Concentrations. Set 1 171

B. 19 Effluent and First Port pH Values. Set l 172

B.20 Effluent ORP Values. Set 1

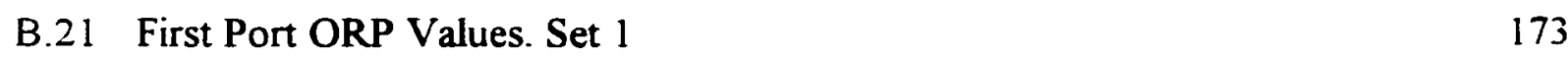

B.22 Analyses along Reactors' Height During Steady State. Set 1

B.23 Effluent and First Port Sulfide Concentrations. Set $2 \quad 175$

B.24 Effluent and First Port VSS Concentrations. Set $2 \quad 175$

B.25 Effluent and First Port pH Values. Set 2

$\begin{array}{lll}\text { B.26 Effluent ORP Values. Set } 2 & 177\end{array}$

$\begin{array}{lll}\text { B.27 First Port ORP Values. Set } 2 & 177\end{array}$

B.28 Analyses along Reactors' Height During Steady State. Set $2 \quad 178$

B.29 Effluent and First Port Sulfide Concentrations. Set $3 \quad 179$

$\begin{array}{lll}\text { B.30 Effluent and First Port VSS Concentrations. Set } 3 & 179\end{array}$

$\begin{array}{lll}\text { B.3 } 1 \text { Effluent and First Port pH Values. Set } 3 & 179\end{array}$ 
$\begin{array}{ll}\text { B.32 Effluent ORP Values. Set } 3 & 180\end{array}$

$\begin{array}{lll}\text { B.33 First Port ORP Values. Set } 3 & 180\end{array}$

B.34 Analyses along Reactors' Height During Steady State. Set $3 \quad 181$

B.35 Effluent and First Port Sulfide Concentrations. Set $4 \quad 182$

B.36 Effluent and First Port VSS Concentrations. Set $4 \quad 182$

B.37 Effluent and First Port pH Values. Set 4

B.38 Effluent ORP Values. Set 4

B.39 First Port ORP Values. Set 4

B.40 Analyses along Reactors' Height During Steady State. Set 4

B.4l Effluent and First Port Sulfide Concentrations. Set $5 \quad 185$

B.42 Effluent and First Port VSS Concentrations. Set $5 \quad 185$

$\begin{array}{lll}\text { B.43 Effluent and First Port pH Values. Set } 5 & 185\end{array}$

$\begin{array}{ll}\text { B.44 Effluent ORP Values. Set } 5 & 186\end{array}$

$\begin{array}{lll}\text { B.45 First Port ORP Values. Set } 5 & 186\end{array}$

$\begin{array}{lll}\text { B.46 Analyses along Reactors' Height During Steady State. Set } 5 & 187\end{array}$ 


\section{LIST OF FIGURES}

I. I Solubility of Metal Hydroxides and Sulfides as a function of $\mathrm{pH}$

$\begin{array}{lll}2.1 & \text { Sulfide Speciation as a function of } \mathrm{pH} & \mathbf{8}\end{array}$

$\begin{array}{lll}2.2 & \text { Schematic Diagram of Sulfur Cycle } & 10\end{array}$

3.1 Experimental Set-Up During Phase I $\quad 28$

3.2 Reactor Configuration. Phase III 35

3.3 Experimental Set-Up During Phase III. View l 36

3.4 Experimental Set-Up During Phase III. View 2

4.1 Mass Balance Lay-Out in a Differential Volume Element 54

$5.1 \quad$ Sulfide Concentration vs Time (2 L Batch Reactors) 62

5.2 ORP vs Time (2 L Batch Reactors) $\quad 62$

5.3 pH vs Time (2 L Batch Reactors) 63

5.4 Sulfide Concentration vs Time ( $10 \mathrm{~L}$ Batch Reactors During $1^{\text {st }}$ and $2^{\text {nd }}$ Sequences) 65

5.5 ORP vs Time ( 10 L Batch Reactors During $1^{\text {st }}$ and $2^{\text {nd }}$ Sequences) 66

$5.6 \mathrm{pH}$ vs Time (10 L Batch Reactors During $1^{\text {st }}$ and $2^{\text {nd }}$ Sequences) 66

5.7 Sulfide Concentration vs Time (10 L Batch Reactors During $3^{\text {rd }}$ and $4^{\text {th }}$ Sequences) 67

5.8 VSS Concentration vs Time ( 10 L Batch Reactors During $3^{\text {rd }}$ and $4^{\text {th }}$ Sequences)

$5.9 \mathrm{pH}$ vs Time (10L Batch Reactors During $3^{\text {rd }}$ and $4^{\text {th }}$ Sequences) 68

5.10 Sulfide Concentration vs Time (10 L Batch Reactors Consecutive) 69

5.11 VSS Concentration vs Time (10 L Batch Reactors Consecutive) 69

5.12 ORP vs Time (10 L Batch Reactors Consecutive) 70

$5.13 \mathrm{pH}$ vs Time (10 L Batch Reactors Consecutive) 70

5.14 Sulfide vs VSS Concentrations for Reactor I (packed).

$4^{\text {th }}$ Sequence 
5. 15 Sulfide vs VSS Concentrations for Reactor II (non-packed).

$4^{\text {th }}$ Sequence

5.16 Sulfide vs VSS Concentrations for Reactor III (non-packed).

$4^{\text {th }}$ Sequence

5. 17 Sulfide vs VSS Concentrations for Non-Packed Reactors II and III

5.18 Effluent Sulfide Concentration vs Time During Continuous Operation (Set 1)

5.19 First Port Sulfide Concentration vs Time During Continuous Operation (Set 1)

5.20 Effluent Sulfide Concentration vs Time During Continuous Operation (Set 2)

5.21 First Pon Sulfide Concentration vs Time During Continuous Operation (Set :)

5.22 Effluent Sultide Concentration vs Time During Continuous Operation (Set 3)

5.23 First Pon Sulfide Concentration vs Time During Continuous Operation (Set 3)

5.24 Effluent Sulfide Concentration vs Time During Continuous Operation (Set 4)

5.25 First Port Sulfide Concentration vs Time During Continuous Operation (Set 4)

5.26 Effluent Sulfide Concentration vs Time During Continuous Operation (Set 5)

5.27 First Port Sulfide Concentration vs Time During Continuous Operation (Set 5)

5.28 Steady State Sulfide and VSS Concentrations vs HRT. Reactor I (packed) 104

5.29 Steady State Sulfide and VSS Concentrations vs HRT.

Reactor II (non-packed)

5.30 Steady State Sulfide and VSS Concentrations vs HRT. 
Reactor III (non-packed) 105

5.31 Reactors II and III (non-packed) Average Curves 105

5.32 Rate of Sulfide and VSS Production vs HRT. Reactor I (packed) 106

5.33 Rate of Sulfide and VSS Production vs HRT. Reactor II (non-packed) 106

5.34 Rate of Sulfide and VSS Production vs HRT. Reactor III (non-packed) 107

5.35 Rate of Sulfide and VSS Production vs HRT. Reactors II and III $\begin{array}{ll}\text { (non-packed) Average Curves } & 107\end{array}$

5.36 Model I: Biomass Production Rate. Reactor I (packed) 113

5.37 Model I: Biomass Production Rate. Reactor II (non-packed) 113

5.38 Model I: Biomass Production Rate. Reactor III (non-packed) 114

5.39 Model II: Sulfide Production Rate. Reactor I (packed) 115

5.40 Model II: Sulfide Production Rate. Reactor II (non-packed) 117

5.41 Model II: Sulfide Production Rate. Reactor III (non-packed) 117

5.42 Model III: Sulfide and Biomass Concentrations Reactor I (packed) 120

5.43 Model III: Sulfide and Biomass Concentrations Reactor II (non-packed) $\quad 120$

5.44 Model III: Sulfide and Biomass Concentrations Reactor III (non-packed) $\quad$ I21

$\begin{array}{lll}\text { A. } 1 & \text { Pump Calibration Curve. Pump } 1 & 160\end{array}$

$\begin{array}{lll}\text { A.2 } 2 \text { Pump Calibration Curve. Pump } 2 & 160\end{array}$

$\begin{array}{lll}\text { A.3 Sulfate Calibration Curve } & 161\end{array}$ 
ABSTRACT

ACKNOWLEDGEMENTS

NOMENCLATURE

LIST OF TABLES

viii

LIST OF FIGURES

CHAPTER 1. INTRODUCTION

1.1 Objectives 4

1.2 Scope 5

1.2.1 Batch Culture in $2 \mathrm{~L}$ Reactors. Phase I 5

1.2.2 Batch System in 10 L Reactors. Phase II 5

1.2.3 Continuous System in 10 L Reactors. Phase III 6

CHAPTER 2. LITERATURE REVIEW

2.1 Sulfate Reducing Bacteria 7

2.2 Competition for Organic Substrate between SRB and MPB 10

2.3 Effect of Temperature 14

2.4 Attached Growth vs Suspended Growth 15

2.5 Effect of Liquid Upflow Velocity 16

2.6 Effect of Hydrogen Sulfide 19

2.7 Heavy Metal Removal 23

2.8 Operational Conditions 25

CHAPTER 3. EXPERIMENTAL PROCEDURE 27

3.1 Experimental Set-Up 27

3.1.1 Experimental Set-Up During Phase I 27

3.1.2 Experimental Set-Up During Phase II 29

3.1.2.1 Reactors 29

3.1.2.2 Seed Material 31

3.1.2.3 Media 31

3.1.3 Experimental Set-Up During Phase III 33 
3.1.3.1 Reactors 33

$\begin{array}{lll}3.1 .3 .2 & \text { Seed Material } & 38\end{array}$

$\begin{array}{lll}3.1 .3 .3 \text { Media } & 38\end{array}$

3.2 Experimental Procedure 40

3.2.1 Experimental Procedure. Phase I 40

3.2.2 Experimental Procedure. Phase II 41

3.2.3 Experimental Procedure. Phase III 43

3.3 Analyses 45

3.3.1 Sulfide 46

$\begin{array}{lll}3.3 .2 & \text { Volatile Suspended Solids } & 47\end{array}$

$\begin{array}{lll}3.3 .3 & \text { Sulfate } & 47\end{array}$

$3.34 \mathrm{pH}$ and ORP $\quad 48$

3.35 Soluble COD 48

336 Bacterial Count 49

CHAPTER \& DEIELOPMENT OF STOICHIOMETRIC AND KINETIC EQLATIONS 50

+1 Stouchiometric Equations 50

42 Kinetc Mlodel Equations 51

421 Kinetic Model I: Biomass Production Rate 52

$f \geq 2$ Kinetic Model II: Sulfide Production Rate 55

$4:$ i Kinetic Model Ill: Sulfide and Biomass Concentrations 57

43 Biomass Characterization 59

+31 Volatile Suspended Solids $\quad 59$

432 Washout Velocity $\quad 59$

CHAPTER 5. RESULTS $\quad 61$

5.1 Phase I 61

$\begin{array}{lll}5.2 & \text { Phase Il } & 63\end{array}$

$\begin{array}{lll}5.3 & \text { Phase III } & 87\end{array}$

$\begin{array}{lll}5.3 .1 & \text { Set } 1 & 87\end{array}$

$\begin{array}{lll}5.3 .2 & \text { Set } 2 & 90\end{array}$

$\begin{array}{lll}5.3 .3 & \text { Set } 3 & 93\end{array}$

$\begin{array}{lll}5.3 .4 & \text { Set } 4 & 95\end{array}$

$\begin{array}{llr}5.3 .5 & \text { Set } 5 & 98\end{array}$

$\begin{array}{ll}\text { 5.3.6 Kinetic Modeling } & 108\end{array}$

5.3.6.1 Kinetic Model I: Biomass Production Rate 108

5.3.6.2 Kinetic Model II: Sulfide Production Rate 114 
CHAPTER 6. DISCUSSION

122

6.1 Analytical Techniques 122

6.2 Phase I 123

$\begin{array}{lll}6.3 & \text { Phase II } & 124\end{array}$

$\begin{array}{ll}\text { 6.3.1 Substrate Composition } & 124\end{array}$

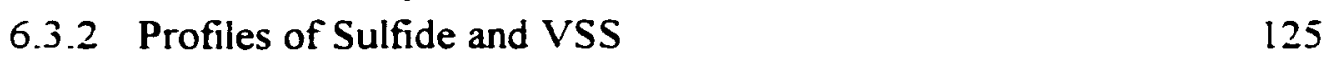

$\begin{array}{lll}6.3 .3 & \text { Stoichiometry } & 126\end{array}$

$\begin{array}{lll}6.4 & \text { Phase III } & 130\end{array}$

6.4.1 General 130

$\begin{array}{lll}\text { 6.4.2 Support Media } & 131\end{array}$

6.4.3 Hydraulic Retention Time 132

6.4.4 Effect of Organic Loading Rate 136

$\begin{array}{ll}6.4 .5 \mathrm{pH} \text { and ORP } & 138\end{array}$

646 Kinetics 139

64.6.1 Biomass Production 140

64.6.2 Sulfide Production 140

$0+7$ Comparison between Batch and Continuous 143

$6+8$ Active Height 144

$(0+1)$ Heary Metals Removal 145

CHAPTER 7 CONCIISSIONS AND RECOMMENDATIONS 147

$\begin{array}{ll}7.1 \text { Conslusons } & 147\end{array}$

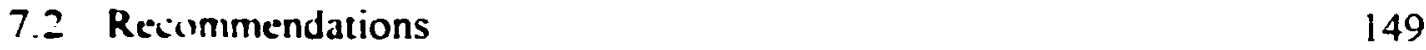

$\begin{array}{ll}\text { REFERENCES } & 150\end{array}$

APPENDIX A C $\cdot$ M IIBR.ATION CURVES

$\begin{array}{ll}\text { A I Pump Calibration } & 159\end{array}$

A.2 Sulfatc Calibration Curve 161

$\begin{array}{ll}\text { APPENDIX B D.AT } & 162\end{array}$

$\begin{array}{ll}\text { B I Phase I } & 162\end{array}$

$\begin{array}{ll}\text { B.2 Phax II } & 164\end{array}$

$\begin{array}{ll}\text { B.3 Phax III } & 171\end{array}$ 
APPENDIX C. STATISTICS

C.I Sulfide Determination

C.2 VSS Determination 


\section{CHAPTER 1. INTRODUCTION}

Anaerobic wastewater treatment constitutes an important biological treatment process in the management of large wastewater streams, and several systems have been developed to solve specific needs. The Fluidized Bed Reactor (FB), Anaerobic Filter (AF), Upflow Anaerobic Sludge Blanket Reactor (UASB) and Upflow Anaerobic Fixed Film Reactor (UAFFR) are the most common anaerobic treatment methods. In these systems, the anaerobic bacteria are immobilized on inert solid particles, e.g. plastic, or are held by an aggregation of the bacteria in a floc with certain settling properties.

The biochemical reaction of interest in the present study is the anaerobic conversion of organic matter and sulfates by means of the dissimilatory sulfate reduction associated with the growth of sulfate reducing bacteria, SRB. These obligate anaerobes use simple organic compounds. such as lactic acid, as electron donors and sulfate as the external electron acceptor. which is reduced to sulfide:

$$
\begin{gathered}
=\mathrm{C}_{1} \mathrm{H}_{1} \mathrm{O}_{3}+3 \mathrm{SO}_{4}^{2-} \rightarrow 3 \mathrm{H}_{2} \mathrm{~S}+6 \mathrm{HCO}_{3}^{-} \\
\mathrm{HCO}_{3}^{-}+\mathrm{H} \rightarrow \mathrm{CO}_{2(\mathrm{~g})}+\mathrm{H}_{2} \mathrm{O}
\end{gathered}
$$

This bacterial production of sulfide has been recognized as an important reaction for removing heary metals as insoluble metal sulfides from contaminated wastewaters:

$$
\mathrm{H}_{2} \mathrm{~S}+\mathrm{M}^{2-} \rightarrow \mathrm{MS}_{(\mathrm{s})}+2 \mathrm{H}
$$

where, M=heai? metal 
Many industrial wastewaters, e.g. the ones generated in tanneries, electroplating processes, edible oil industries, mining and processing of metals, paper mills, potato starch factories and petroleum refining, contain considerable amounts of sulfate and/or heavy metals (McCartney et al., 1990; Genschow et al., 1996; Dries et al., 1998; De Vegt et al., 1999). The biological removal of sulfate and heavy metals as metal sulfides represents a very important treatment process and has remarkable advantages over other physicochemical methods (El Bayoumy et al., 1999b):

- High removal efficiencies are possible with sulfide precipitation due to the low solubility of metal sulfides, lower than metal hydroxides.

- The applicability of some other physicochemical methods depends on the incorporation of pretreatment schemes or post-treatment processes in order to improve the overall treatment system performance.

- Smaller volumes of sludge are produced with sulfide precipitation.

- Metal sulfides do not redissolve within a wider $\mathrm{pH}$ range than metal hydroxides as shown in Figure 1.1.

- The cost of metal precipitants is no longer an issue, since sulfide precipitant is produced by means of SRB metabolism under certain environmental conditions in a reactor.

The biological oxidation of organic matter combined with the sulfate reduction to produce sulfide, requires the optimum conditions in a biological reactor. Therefore, it is important to provide the suitable environmental conditions for the SRB optimum 


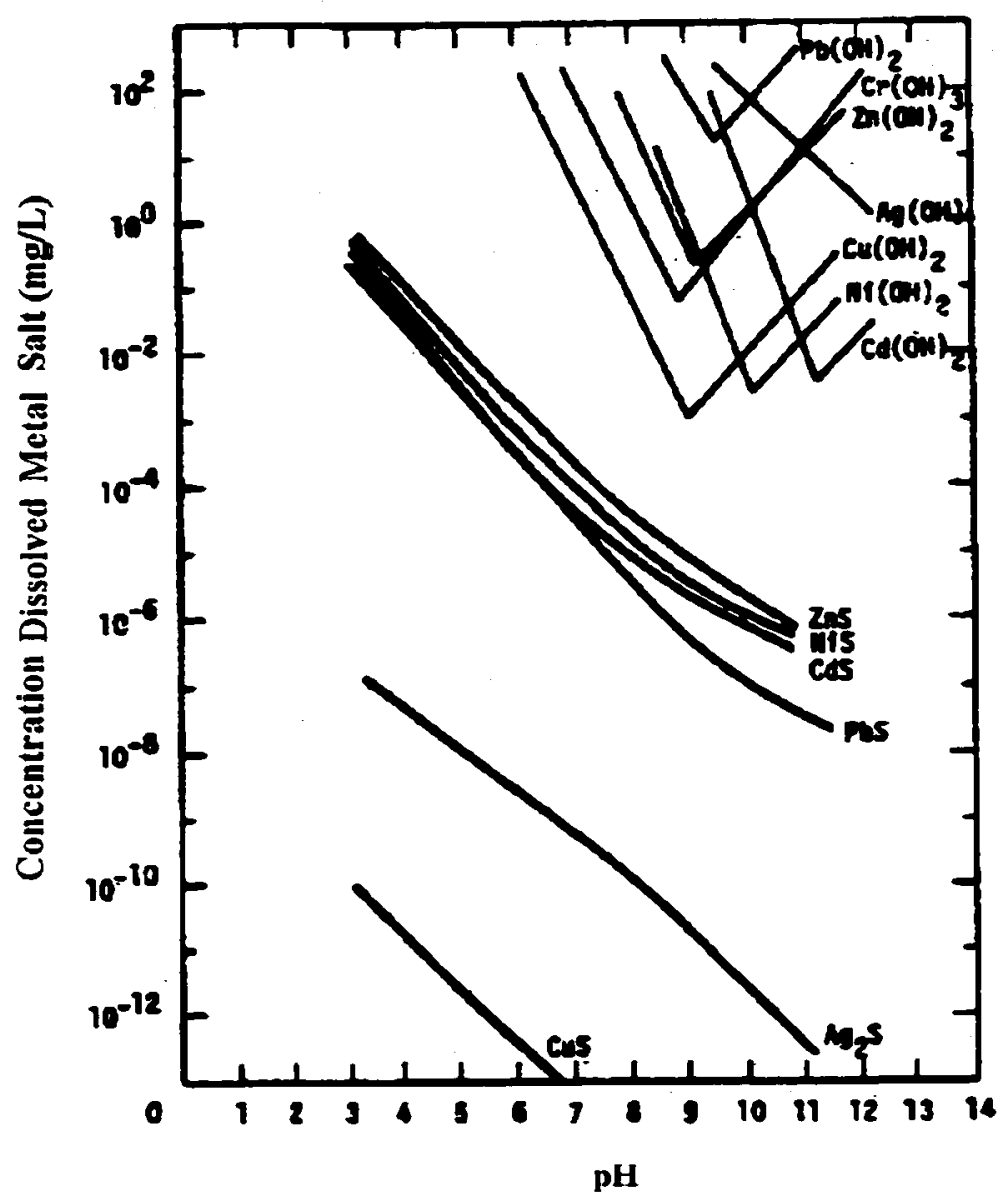

Figure 1.1 Solubility of Metal Hydroxides and Sulfides as a function of $\mathrm{pH}$ (U.S. EPA, 1985 as found in McArdle et al., 1988)

growth. The $\mathrm{pH}$ of the system, number of viable and active cells, temperature, upflow velocity that translates to effective biomass retention, substrate composition and the organic loading rate, are important parameters to optimize in order to maximize sulfide production (Speece, 1996). Low $\mathrm{pH}(<5-6)$ inhibits sulfate reduction activity and increases the solubility of metal sulfides. The upflow velocity, which is related to the 
hydraulic retention time in a given cross sectional area, plays an important role in retaining a high concentration of the biomass in the reactor so that higher organic loading rates can be applied in these anaerobic treatment systems and specific reactions can be controlled and/or maximized.

With this background, the aim of the present study was to compare the process behavior of three UA reactors, one packed with polypropylene pall rings and the other two nonpacked, to establish the ability of SRB to attach to an inert surface and form a biofilm that can improve the process of sulfate reduction. At the same time, a comparison between the three UA reactors was carried out varying the hydraulic retention time, $H R T$, in order to establish the optimum conditions for maximum sulfide production by SRB and to determine the critical upflow velocity at which the biomass is washed out from the bioreactors.

\subsection{Objectives}

- Compare the effect of packing material for attached growth with suspended growth on the performance of SRB in an upflow anaerobic reactor.

- Establish the effect of the hydraulic retention time on the sulfide production rate in an upflow anaerobic reactor.

- Determine the critical upflow velocity at which the biomass is washed out from the reactor.

- Determine the rate kinetics of sulfide production by SRB. 


\subsection{Scope}

The scope of the present study was as follows:

\subsubsection{Batch Culture in 2 L Reactors. Phase I}

1.2.1. 1 Obtain a healthy culture of SRB to be used as seed for subsequent experiments.

1.2.1.2 Establish the substrate composition and frequency of feeding to a batch culture of SRB.

\subsubsection{Batch System in 10 L Reactors. Phase $\mathrm{I}$}

1.2.2.1 Establish the effect of packing material on the performance of SRB in $10 \mathrm{~L}$ batch anaerobic reactors.

1.2.2.2 Study the sulfide production in $10 \mathrm{~L}$ reactors under batch operation.

1 2.2.3 Establish the optimum substrate composition for the SRB growth.

1 2.2.4 Determine the SRB behavior at different depths in $10 \mathrm{~L}$ reactors under batch conditions.

1.2.2.5 Determine the stoichiometry for lactate oxidation, sulfate reduction, cell synthesis and overall system reactions. 


\subsubsection{Continuous System in 10 L Reactors. Phase III}

1.2.3.1 Determine the effect of packing material on the performance of SRB in an upflow anaerobic reactor.

1.2.3.2 Establish the concentration gradients of sulfide and volatile suspended solids, VSS, along the height of the reactors under continuous flow conditions.

1.2.3.3 Establish the critical hydraulic retention time for maximum sulfide production and suspended growth of SRB.

1.2.3.4 Establish the critical upflow velocity for complete biomass washout from an upflow anaerobic reactor.

1.2.3.5 Determine the kinetic parameters for the sulfide production process in an upflow anaerobic reactor. 


\section{CHAPTER 2. LITERATURE REVIEW}

\subsection{Sulfate Reducing Bacteria}

A specific group of anaerobes, collectively called sulfate reducing bacteria, SRB, carries out, under certain environmental conditions, the oxidation of organic substrates and the reduction of the sulfate ions, $\mathrm{SO}_{4}{ }^{2-}$. Sulfate ions act as electron acceptors during an energy-generating process and are reduced to sulfide. The simplified reaction is shown below (Hao et al., 1996):

$$
\text { Organic Matter }+\mathrm{SO}_{4}^{2-} \leftrightarrow \mathrm{HS}^{-}+\mathrm{H}_{2} \mathrm{O}+\mathrm{HCO}_{3}^{-}
$$

The distribution of different sulfide species, $\mathrm{H}_{2} \mathrm{~S}, \mathrm{HS}^{-}$and $\mathrm{S}^{2-}$, is a function of $\mathrm{pH}$. Therefore, it is extremely important to control the system's $\mathrm{pH}$ to drive the equilibrium to the specie of interest. The distribution of sulfide species as a function of $\mathrm{pH}$ is shown in Figure 2.1.

Three oxidation states of sulfur are found in significant amounts in nature (Hao et al., 1996):

(i) Oxidation state -2: R-SH sulfhydryl and sulfide HS $^{-}$.

(ii) Oxidation state 0: elemental sulfur $\mathrm{S}$.

(iii) Oxidation state 6+: sulfate $\mathrm{SO}_{4}{ }^{2-}$, a very important ion, which is often found in different types of wastewater. 


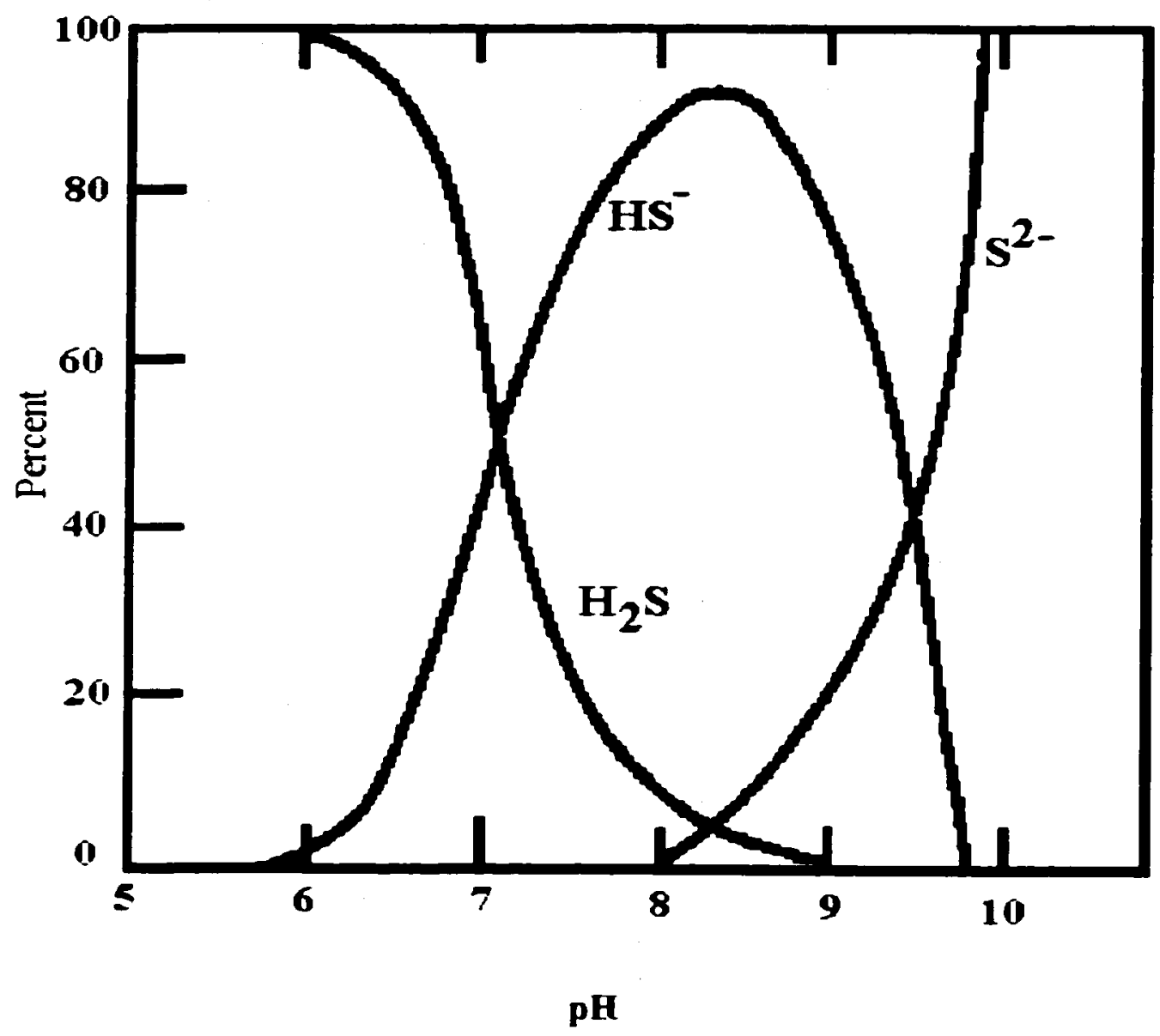

Figure 2.1 Sulfide Speciation as a function of pH (Hao et al., 1996)

Analytically, three categories of sulfide in water and wastewater are distinguished (APHA, 1995; Mizuno et al.. 1998b):

(i) Total sulfide: includes dissolved $\mathrm{HS}^{-}, \mathrm{S}^{2-}, \mathrm{H}_{2} \mathrm{~S}$, and insoluble sulfide-S such as ferrous sulfide, FeS.

(ii) Dissolved sulfide consists of ionized sulfide, $\mathrm{HS}^{-}$and $\mathrm{S}^{2-}$, and free $\mathrm{H}_{2} \mathrm{~S}$.

(iii) Un-ionized hydrogen sulfide gas, can be calculated from the concentration of dissolved sulfide, $\mathrm{pH}$ of the sample and ionization constant, $\mathrm{K}_{\mathrm{s}}$, of $\mathrm{H}_{2} \mathrm{~S}$. 
The un-ionized $\mathrm{H}_{2} \mathrm{~S}$ in the liquid phase is in equilibrium with the $\mathrm{H}_{2} \mathrm{~S}$ in the gas phase, approximately $26 \mathrm{mg} / \mathrm{L} \mathrm{H}_{2} \mathrm{~S}$ are in the liquid phase for each $1 \% \mathrm{H}_{2} \mathrm{~S}$ in the gas phase at $35{ }^{\circ} \mathrm{C}$, while the $\mathrm{pH}$ determines the sulfide equilibrium in the liquid phase by the following reaction (Speece, 1996):

$$
\mathrm{H}_{2} \mathrm{~S} \leftrightarrow \mathrm{HS}^{-}+\mathrm{H}^{-} \quad \mathrm{pK}=7
$$

Microbial activities determine what is called the biological sulfur cycle, shown in Figure 2.2 (Brock and Madigan, 1991 as found in Hao et al., 1996). One important characteristic of SRB in this cycle is that they can only degrade low-molecular-mass compounds like volatile acids, e.g. acetate, organic acids, e.g. lactate or pyruvate, and alcohols, e.g. ethanol. But the end products of the reactions depend on the SRB genera involved. Desulfovibrio genus, commonly named incomplete SRB, does not completely utilize lactate, but just degrades it to acetate. On the other hand, Desulfotomaculum genus can utilize acetate or in some cases glucose (Reis et al., 1992; Hao et al., 1996).

SRB are obligate anaerobes and are not inhibited by temporary exposures to oxygen. This is related as well with the redox potential of the system in which SRB are grown. Postgate (1984) refers a redox potential of $-100 \mathrm{mV}$ as necessary for the growth of SRB. SRB are adaptable to almost any environment, they tolerate temperatures from below -5 to $75^{\circ} \mathrm{C}$ and $\mathrm{pH}$ values ranging from 5.0 to 9.5 (Postgate, 1984; Perry, 1985). 


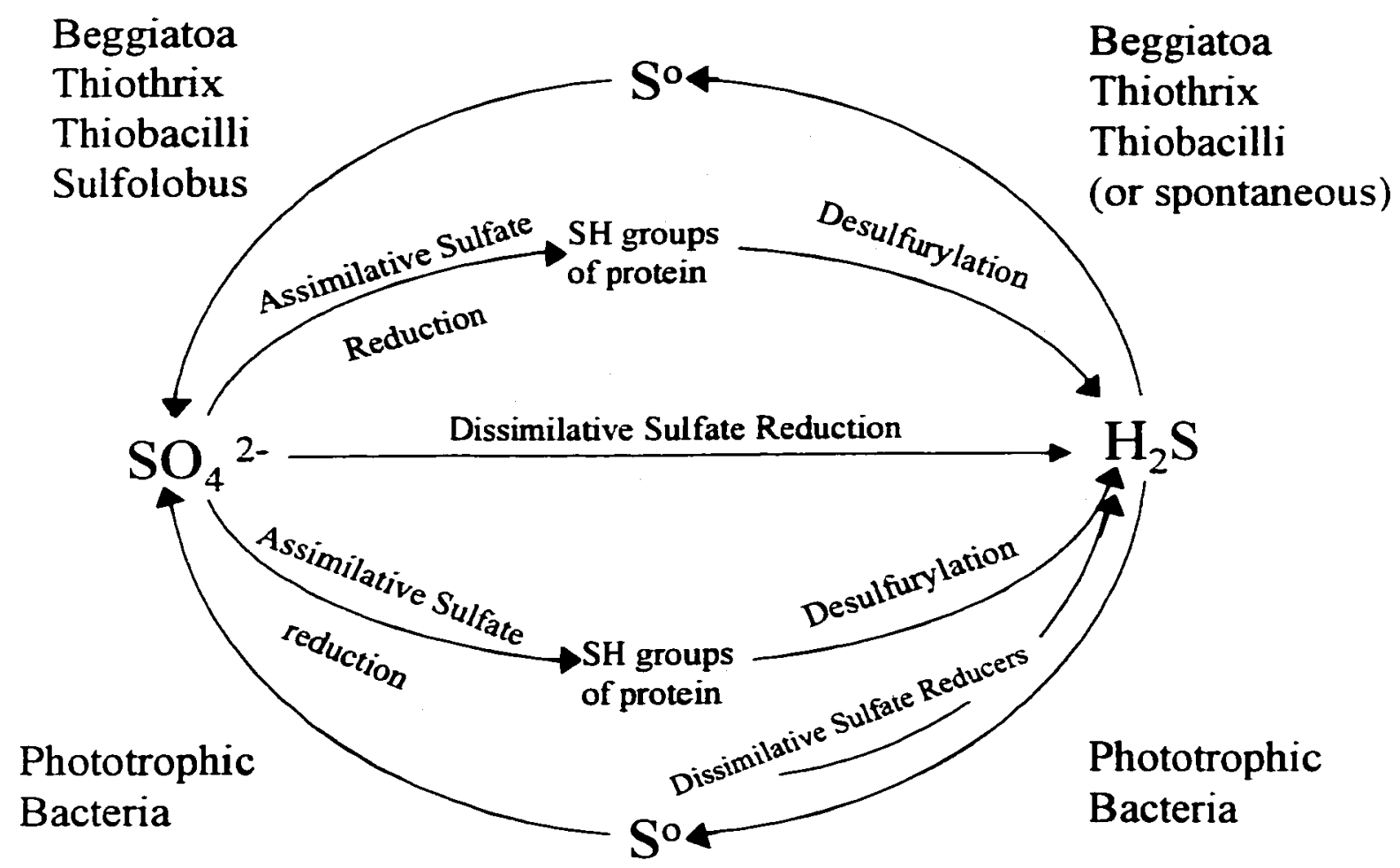

Figure 2.2 Schematic Diagram of Sulfur Cycle (Brock and Madigan, 1991 as found in Hao et al., 1996)

\subsection{Competition for Organic Substrate between SRB and MPB}

In the anaerobic treatment of wastewater, both sulfate reduction and methanogenesis can take place. Therefore, a competition between sulfate-reducing bacteria (SRB) and methane-producing bacteria (MPB) may occur because both are capable of using hydrogen and acetate or the organic substrate present. The importance of the competition between SRB and MPB relies on the type of wastewater that can be treated based on the 
metabolism followed by a certain culture at certain environmental conditions. This competition is strongly dependant on the $\mathrm{COD}$ to sulfur ratio as well as the $\mathrm{pH}$ of the system (McCartney and Oleszkiewicz, 1993).

During normal anaerobic wastewater treatment, hydrogen and acetate are intermediate products and precursors to methane formation. The formers can function as electron donors for sulfate reduction, therefore, MPB and SRB may be considered competitors for these substrates M1cCartney and Oleszkiewicz (1993) discussed the competition in terms of thermodynamic and kinetic factors. In terms of free energy changes for acetate and hydrogen. at standard conditions, SRB would out-compete MPB.

Nevertheless. the portential for MPB to out-compete SRB is present, when the electron donor (acetate. hudrugen or an organic) to sulfate ratio becomes high or, when a buildup of sulfide occurs In the case of SRB, these bacteria out-compete MPB when the electron donor to sulfate ratıo is low and if sulfide concentrations and $\mathrm{pH}$ are not high.

Choi and $\operatorname{Rim}(1991)$ have pointed out that SRB and MPB are in competitive relation for substrate utilization. They found that, with enough carbon source, as $\mathrm{COD}: \mathrm{SO}_{4}{ }^{2-}$ decreased to 1.7 , the sulfate reduction efficiencies increased, and below 1.7 , the efficiencies decreased, independent of the hydraulic retention time. When the ratio exceeded 2.7 , methane producers began to predominate. These findings are very similar to those of Bhattacharya et al. (1996), who concluded that with high sulfate and low acetate concentrations $(<10 \mathrm{mg} / \mathrm{L})$, SRB were predominant. Dries et al. (1998) reported a 
complete sulfidogenesis, in which SRB accounted for $70-85 \%$ of the total COD uptake throughout their experiment, based on the $\mathrm{COD}$ to $\mathrm{SO}_{4}{ }^{2-}$ as $\mathrm{S}$ ratio, $\mathrm{COD}: \mathrm{S}$, of 2.0-2.2, slightly alkaline conditions $(\mathrm{pH}=7.9)$ and high sulfate loading rate of $10.4 \mathrm{~g} \mathrm{SO}_{4}{ }^{2-}$ as S/L/d.

McCartney and Oleszkiewicz (1993) cited the work of Isa et al. (1986a), which supported the theory that the $\mathrm{COD}$ to $\mathrm{SO}_{4}{ }^{2-}$ ratio determined whether or not $\mathrm{SRB}$ would outcompete MPB. It is important to note that this ratio can be interpreted as a factor in the stoichiometric sulfate requirements for SRB metabolism and in the kinetics of substrate utilization. McCartney and Oleszkiewicz (1993) pointed out in their study that a lower $\mathrm{COD}: \mathrm{SO}_{4}{ }^{2-}$ drives the metabolic pathway to a complete oxidation of lactate via sulfate reduction, without intermediate products as propionate, coinciding with the findings of Harada el al $(1(m)+$. All related studies support the fact that a pathway taken is highly dependent on the ens ironmental conditions provided, and if those change, the pathway involved can chanter as " ell

Harada et al (lwas) fiund that the methane production was influenced by the sulfate levels in the feed solutions, having lower methane production at higher levels of sulfate $\left(\mathrm{g} \mathrm{SO}_{4}{ }^{2-}\right.$ as $\mathrm{S} \& \mathrm{COD}$ imposed=0.4) due to the increment in sulfate reduction rate with time and was independent of the loading rate. This coincides with the work of Mizuno et al. (1994) who consluded that at the $\mathrm{COD}$ to $\mathrm{SO}_{4}{ }^{2-}$ as $\mathrm{S}$ ratio of 6 or more, methane production was the predominant reaction, while at the $\mathrm{COD}$ to $\mathrm{SO}_{4}{ }^{2-}$ as $\mathrm{S}$ ratio of 1.5 , SRB utilized more than $50^{\circ} \%$ of the total electron flow. Omil et al. (1997) found that a 
decrease from 2.0 to 1.0 of the COD to sulfate ratio in the influent resulted in an increase of the fraction of acetate utilized by SRB to $40-50 \%$, while in the long-term operation and at COD:sulfate of 0.5 , a complete acetate removal by ASRB was accomplished.

Mizuno et al. (1994) used concentrations of organic and sulfate sources, $2500 \mathrm{mg}$ COD/L as butyric acid and $1667 \mathrm{mg} / \mathrm{L}$ of sulfate with $\mathrm{COD}: \mathrm{SO}_{4}{ }^{2-}$ as $\mathrm{S}$ of 1.5 . The researchers concluded that SRB did not out-compete MPB for acetate at a $\mathrm{COD}: \mathrm{SO}_{4}{ }^{2-}$ as $\mathrm{S}$ ratio greater than 3 . In the present study, one of the conditions tested used $2500 \mathrm{mg}$ Th.O.D.R as lactic acid and $1250 \mathrm{mg} / \mathrm{L}$ of sulfate with Th.O.D.:SO ${ }^{2-}$ of 2 .

Harada et al. (1994) related some of their observations on the competition of SRB and MPB for acetate and hydrogen to $V_{M} / K_{M}$ found in the literature, where $V_{M}$ is the maximum specific acetate or hydrogen consumption rate and $K_{M}$ is the half velocity constant for the specific substrate consumption. The higher the value of the ratio, the more favorable is the competition for a certain group of bacteria. SRB tend to outcompete MPB for both acetate and hydrogen, having a higher $\mathrm{V}_{\mathrm{M}} / \mathrm{K}_{\mathrm{M}}$. This contrasted with their own findings, in which just a small fraction of the COD eliminated was utilized for sulfate reduction from acetate. This is in agreement with Polprasert and Hass (1995) who concluded that acetic acid was not a major substrate for sulfate reduction in an anaerobic mixed culture.

Similarly, Isa et al. (1986a) found that acetate conversion by SRB were not competitive in a high-rate anaerobic reactor, arguing that SRB were not able to colonize and adhere as well as MPB to the carrier matrix and therefore were easily washed out. However, during 
long-term operation, SRB became more competitive in comparison with MPB due to their higher affinity for substrate and higher substrate removal rate. El Bayoumy et al. (1999a) confirmed that in sulfate-poor environment, Th.O.D.:SO ${ }_{4}^{2-}$ higher than 2.25, MPB started to out-compete SRB. Therefore, in general, a sulfate-rich environment is preferred over a sulfate-poor environment.

\subsection{Effect of Temperature}

Visser et al. (1993) studied the effect of temperature shocks on the performance of a mesophilic $\left(30^{\circ} \mathrm{C}\right)$ UASB reactor fed with synthetic medium of acetate, propionate, butyrate and sulfate, in which competition between sulfate-reducing and methanogenic bacteria could take place. The effect of temperature was observed to be a function of the type of sludge involved, the exposure time to a certain temperature shock and the change in temperature applied. The authors observed that at 55 and $65^{\circ} \mathrm{C}$ there was an important decrease of the mesophilic sludge activity, while the acetate oxidation was more sensitive than the propionate and butyrate ones. In the same way, sulfate reduction was less sensitive to temperature shocks than methanogenesis and, therefore, the sulfate reduction process could recover fairly quickly after a temperature shock.

Hao et al. (1996) reported an optimum temperature for SRB pure culture growth and consequently for high sulfate reduction rates, in the range of $28-32{ }^{\circ} \mathrm{C}$, although for certain genera it was as high as $70^{\circ} \mathrm{C}$. 


\subsection{Attached Growth vs Suspended Growth}

Reis et al. (1992) reported that inhibition of sulfide concentration for SRB was a function of the type of reactor involved. There was a slight inhibition in immobilized cell reactors because cells were better protected from the adverse environmental factors than in suspended growth reactors. McCartney and Oleszkiewicz (1993) referred to the work of Isa et al. (1986a) and Yoda et al. (1987) with the purpose of analyzing the competition of SRB and MPB in terms of differential bacterial attachment. The former had used a batch attached growth reactor while the latter had used a continuous-feed attached growth system. They found that the bacterial attachment determined the increase in MPB population as compared to the SRB population. Isa et al. (1986a) reported that the MPB population was $200(1)$ times larger in the biofilm as compared to the effluent. In contrast, the SRB populatıon was just 30 times larger in the biofilm as compared to the effluent. They concluded that SRB did not attach as readily to the support media and the washout was more evident

El Bayoumy al al $(10(0)$ b) concluded that the type and/or characteristics of the packing material did not affese the growth and production of the SRB in an Upflow Anaerobic Fixed-Film (L AFF I reditur The authors also observed visually that the SRB biomass did not attach to the pashins material and preferably settled down on the packing material. Higher bacterial concentration was observed near the bottom of the reactor. 


\subsection{Effect of Liquid Uphow Velocity}

Although most researchers have reported results in terms of total COD and soluble COD removal efficiencies in an UASB reactor, the maximum sulfide production or maximum organic-COD removal by SRB, as a function of the hydraulic retention time has been established by just a few (Alphenaar et al., 1993; Singh et al., 1996). Alphenaar et al. (1993) studied the effect of hydraulic retention time and liquid upflow velocity on the granulation process in an UASB reactor, with no support media, and the competition for acetate between sulfate-reducing and methane-producing bacteria. They found that the fraction of organic material used by sulfate-reducers increased with time and at a hydraulic retention time of $40 \mathrm{~h}$. The authors pointed out that, based on thermodynamic data with Gibbs free energies values, the oxidation of hydrogen and acetate with sulfate reduction, SRB driven, is more favorable than the oxidation of hydrogen and acetate with methane formation, MPB driven. Therefore, SRB may out-compete MPB as shown in reactions 2.3 through 2.6 .

\section{Biochemical Reaction}

$$
\begin{aligned}
& 4 \mathrm{H}_{2}+\mathrm{SO}_{4}{ }^{2-}+\mathrm{H}^{+} \rightarrow \mathrm{HS}^{-}+4 \mathrm{H}_{2} \mathrm{O} \\
& 4 \mathrm{H}_{2}+\mathrm{HCO}_{3}{ }^{-}+\mathrm{H}^{+} \rightarrow \mathrm{CH}_{4}+3 \mathrm{H}_{2} \mathrm{O} \\
& \mathrm{CH}_{3} \mathrm{COO}^{-}+\mathrm{H}_{2} \mathrm{O} \rightarrow \mathrm{CH}_{4}+\mathrm{HCO}_{3}{ }^{-} \\
& \mathrm{CH}_{3} \mathrm{COO}^{-}+\mathrm{SO}_{4}{ }^{2-} \rightarrow \mathrm{HS}^{-}+2 \mathrm{HCO}_{3}^{-}
\end{aligned}
$$

$\Delta \mathbf{G}^{\circ}$

(kcal/reaction)

$-39.5$ 
But beside thermodynamic and kinetic factors, the competition between SRB and MPB depends on several parameters, such as the organic loading rate, theoretical oxygen demand:sulfate, $\mathrm{pH}$ and the retention of biomass in the reactor.

Alphenaar, et al. (1993) used three PVC UASB reactors with a liquid volume of I.I L. The height of the reactors was $400 \mathrm{~mm}$ and the diameter was $6 \mathrm{~mm}$. The third UASB was followed by a continuously stirred, $5 \mathrm{~L}$, PVC tank reactor in order to increase the retention time. In the second and third UASB reactors, effluent recycling was used to increase the upflow velocity. The recycling factor was 10. The organic substrate consisted of $50 \%$ acetic acid, $40 \%$ propionic acid and $10 \%$ sucrose, having an influent $\mathrm{pH}$ of 6.8 and COD to sulfate ratio of 0.5 . The hydraulic retention times were $7.5,6.9$ and $40.2 \mathrm{~h}$, while the upflow velocities were $0.05,0.65$ and $0.65 \mathrm{~m} / \mathrm{h}$, for UASB I, UASB II and UASB+CSTR, respectively. The start up period for this study was 50 days. The results showed that the amount of total-organic COD oxidized by SRB increased with time for the reactor sludge. The authors pointed out that a combination of an $\mathrm{UASB} / \mathrm{CSTR}$ and a relatively longer HRT were more favorable for SRB with respect to acetate competition between SRB and MPB. The washout of both suspended-growing SRB and MPB occurred in UASB reactors operated at a HRT of 7-7.5 h, suggesting that the operation of anaerobic reactors at a longer HRT is favorable for SRB, growing either in dispersed or immobilized form. They also found that the hydraulic regime in the reactor played an important role in the concentrations of SRB, and a completely mixed system with recirculation enhanced the development of SRB in comparison with a plugflow system. 
Choi and Rim (1991) worked with laboratory anaerobic contact units and a municipal digester, which were operated at $35^{\circ} \mathrm{C}$ with hydraulic retention times from $0.5-6$ days and fed with synthetic substrate made of acetic acid supplemented with nutrients. The authors found that with longer hydraulic retention times, greater sulfate and COD reductions were obtained while the inhibitory concentrations of sulfide were higher.

Yoda et al. (1987) found that the percent of electron flow to SRB increased by increasing the hydraulic retention time, HRT, of the reactor. This contrasts with the findings of Mizuno et al. (1994), who reported that at the same $\mathrm{COD}: \mathrm{SO}_{4}{ }^{2-}$ as $\mathrm{S}$, the electron flow used for SRB increased during steady-state conditions, from $51 \%$ to $67 \%$, when the hydraulic retention time was changed from 20 to 5 days.

Singh et al. (1996) used $3 \mathrm{~h}$ of HRT, with an up-flow velocity of $1.3 \mathrm{~m} / \mathrm{h}$, in an UASB at an organic loading rate of $4 \mathrm{~kg} \mathrm{COD} / \mathrm{m}^{3} \mathrm{~d}$, and obtained an effluent suspended solids, $\mathrm{SS}$, concentration of $50 \mathrm{mg} / \mathrm{L}$. The authors reported that a severe granule washout was noticeable at $3 \mathrm{~h}$ of HRT, but was lower than $30 \mathrm{mg} / \mathrm{L}$ for other retention times of 4 and 6 $\mathrm{h}$ with upflow velocities of 1 and $0.67 \mathrm{~m} / \mathrm{h}$, respectively. They also found that the soluble COD removal of $88 \%$ as well as the effluent sulfide concentration of $75 \mathrm{mg} / \mathrm{L}$ were fairly constant irrespective of the organic loading rate. In this study, more than $75 \%$ of the influent COD was reduced in the granular sludge bed zone of the reactor and the MLSS, $\mathrm{COD}$ and $\mathrm{SO}_{4}{ }^{2-}$ concentrations tended to decrease along the reactor height. The highest activity of SRB was found in the first $100-300 \mathrm{~mm}$ of the reactor's height. 
Agrawal et al. (1997b), found that the COD removal efficiency in an UASB reactor increased as the HRT was reduced from 28 to $9 \mathrm{~h}$. The authors observed that a further decrease in HRT caused a complete failure of the process, due to the flotation of a considerable amount of sludge to the top of the reactor. Dries et al. (1998) reported that, at an upflow velocity of $20 \mathrm{~m} / \mathrm{h}$ and $1.9 \mathrm{~h}$ of $\mathrm{HRT}$, there was a significant loss of biomass into the effluent, causing a drop in the sulfate reduction rate and in the COD removal. This high value of liquid upflow velocity is contrasted with the one at which the study of De Smul and Verstraete (1999) was operated. The authors varied the liquid upflow velocity between 3 and $12 \mathrm{~m} / \mathrm{h}$, finding $3 \mathrm{~m} / \mathrm{h}$ better for the retention of the biomass in the reactor and maintaining the SS concentration in the effluent below $20 \mathrm{mg} / \mathrm{L}$.

Mizuno et al. (1998b) studied the effect of sulfate removal in anaerobic chemostat systems under steady-state condition. They observed that the sulfate removal efficiency increased with an increase in HRT that was varied between 2 and $12 \mathrm{~h}$, with $2 \mathrm{~h}$ as the critical hydraulic retention time. The authors recommended a hydraulic retention time longer than $8 \mathrm{~h}$. They also reported that the concentration of total sulfide, dissolved sulfide ( $\left.\mathrm{HS}^{-}, \mathrm{S}^{2-}, \mathrm{H}_{2} \mathrm{~S}\right)$ and free-hydrogen sulfide $\left(\mathrm{H}_{2} \mathrm{~S}\right)$ increased with an increase in HRT, reaching 170,136 and $99 \mathrm{mg} \mathrm{S} / \mathrm{L}$, respectively.

\subsection{Effect of Hydrogen Sulinde}

One important factor that affects the growth and activity of SRB is sulfide, a metabolic product from sulfate reduction. The effect of the imposed environmental conditions, as 
$\mathrm{pH}$ or the sulfide concentration, on the kinetic growth properties of SRB and MPB is very important; the former is a key factor in a sulfide inhibition mechanism resulting in the oscillating coexistence between SRB and MPB. Okabe et al. (1995) pointed out that pH, sulfide concentration, trace nutrients and substrate could not be maintained at the same levels over many generations because of the batch nature of the systems studied.

Choi and Rim (1991) reported the inhibitory concentrations of sulfide to be 120-140 $\mathrm{mg} / \mathrm{L}$ for methane producers, and $160-200 \mathrm{mg} / \mathrm{L}$ for sulfate reducers in anaerobic contact units. They showed that COD was continuously removed at different organic loading rates, thereby producing different sulfide concentrations. This would suggest that the inhibitory effect of sulfide varied with the substrate. These researchers did not distinguish between ionized and un-ionized sulfide in their work.

Reis et al. (1992) studied the effect of $\mathrm{pH}$ and hydrogen sulfide on growth of SRB in batch reactors. Values of the specific growth rate, $\mu_{\max }$, and growth yield coefficients, $\mathrm{Y}$, were calculated in the absence of hydrogen sulfide by continuous stripping of the system. The maximum values for both parameters were found at $\mathrm{pH}$ of 6.6 . They also found that the hydrogen ion, $\mathrm{H}^{+}$, was the growth inhibitor for the SRB culture used in their study, since hydrogen sulfide, a potential inhibitor, was eliminated from the system. Reis et al. (1992) performed further experiments at constant $\mathrm{pH}$ values of 6.2 and 6.6 , to verify if the inhibition on SRB was due to the direct toxicity of the sulfide produced or due to iron precipitation and consequently lack of iron for the microorganisms growth. They observed that the sulfide was the inhibitor of SRB and that it was a reversible process. 
The sulfate uptake rate was increased during the lag and early logarithmic phases, after which a progressive decrease was observed due to the higher sulfide concentration. The authors reported the toxic concentration of hydrogen sulfide to be $547 \mathrm{mg} / \mathrm{L}$. As the $\mathrm{pH}$ increased, hydrogen sulfide was the inhibitor of concern, so that at near neutral $\mathrm{pH}, \mathrm{SRB}$ was affected by the hydrogen sulfide and not by the acetic acid produced in the incomplete oxidation of lactate. This agreed with the findings of McCarney et al. (1990), which supported that as $\mathrm{pH}$ increased, hydrogen sulfide became the inhibitor of concern because the acetate uptake rate for the reactors remained the same.

McCartney et al. (1990) have referred to the work of Rinzema and Lettinga (1988) who observed a significant decrease in propionate removal efficiency with hydrogen sulfide concentrations above $100 \mathrm{mg} / \mathrm{L}$. Hilton and Oleszkiewicz (1988) pointed out that SRB, under batch conditions, were inhibited in proportion to the total sulfide concentration and not the hydrogen sulfide concentration. Nevertheless, McCartney et al. (1990) concluded that MPB were more sensitive to sulfide than the SRB, regardless of total sulfide concentration or $\mathrm{pH}$.

McCartney and Oleszkiewicz (1993) reported un-ionized sulfide concentrations of 185 $\mathrm{mg} / \mathrm{L}$ for $50 \%$ inhibition of SRB activity at $\mathrm{pH} 8$ in serum bottles using a mixed culture in a lactate-sulfate medium, while at pH 7 concentrations below $300 \mathrm{mg} / \mathrm{L}$ did not inhibit SRB activity. Omil el al. (1997) found that an acclimated acetate-consuming SRB could operate under 100 and $800 \mathrm{mg} / \mathrm{L}$ free and total sulfide concentrations, respectively. Yamaguchi et al. (1999) reported $100 \mathrm{mg} / \mathrm{L}$ of un-dissociated sulfide as the limit for a 
satisfactory COD removal performance. McCartney and Oleszkiewicz (1993) further concluded that a prolonged exposure to high sulfate, high lactate and elevated sulficie concentrations would affect the selection of a specific type of SRB species or the stimulation of a different metabolic pathway for SRB. The authors also concluded that SRB growing on a more complex substrate, like lactate, may be less sulfide sensitive than SRB grown on propionate, which agrees with the observation of Choi and Rim (1991).

Okabe et al. (1992) reported that sulfide inhibition of SRB was present when sulfide species, $\mathrm{H}_{2} \mathrm{~S} . \mathrm{HS}^{-}$and $\mathrm{S}^{2-}$, combined with the iron in the cell, caused electron transport systems to stop activity. Therefore the $\mathrm{pH}$ of the system was very important because it determined the distribution of sulfide species. At $\mathrm{pH} 7$, the $\mathrm{H}_{2} \mathrm{~S}$ to $\mathrm{HS}^{-}$ratio was about $1: 1$ ( $\mathrm{pKa}$ of $\mathrm{H}_{2} \mathrm{~S}$ is 7 at $25^{\circ} \mathrm{C}$ ). The percentage of un-ionized $\mathrm{H}_{2} \mathrm{~S}$ drops from $90 \%$ at $\mathrm{pH} 6$ to $50 \%$ at $\mathrm{pH} 7$ (Figure $=1$ ). The authors reported a noticeable inhibition by un-ionized $\mathrm{H}_{2} \mathrm{~S}$, more than total sultide Okabe et al. (1995) separated the effect of sulfide inhibition into an effect on cell yield (growth) and on lactate utilization rate (activity) in a chemostat. They found that the growth had decreased at concentrations of $437 \mathrm{mg} \mathrm{S} / \mathrm{L}$, while the activity was not affected in the range of $332-437 \mathrm{mg} \mathrm{S} / \mathrm{L}$. The cell yield was found to be maximum at $108 \mathrm{mg} \mathrm{S} / \mathrm{L}$. In an earlier study by Okabe et al. (1992), it was reported that a total sulfide concentration of $280 \mathrm{mg} / \mathrm{L}$ dramatically decreased cellular production, and that lactate utilization and cellular production in a chemostat were strongly inhibited at total sulfide concentration of $600 \mathrm{mg} / \mathrm{L}$. 
Maillacheruvu and Parkin (1996) found that the acetate-utilizing SRB were more sensitive to sulfide toxicity and they concluded that the sulfide toxicity was a function of $\mathrm{pH}$ and the specific group of SRB involved. One important conclusion made by Hao et al. (1996) was that the different sensitivities to $\mathrm{H}_{2} \mathrm{~S}$ and dissolved sulfide were function of the organic substrate (electron donor) fed into the system and the type of anaerobic reactor used, an anaerobic filter or suspended growth reactors.

\subsection{Heavy Metals Removal}

Gundry et al. (1990) studied the removal of metals from electroplating wastewater based on an anaerobic degradation of organics by $\mathrm{SRB}$, which used sulfate, $\mathrm{SO}_{4}{ }^{2-}$, as an electron acceptor and reduced them to sulfide, $S^{2-}$. The sulfide was then available to precipitate metals as metal sulfides. These researchers operated the anaerobic filters at a retention time of $24 \mathrm{~h}$ and fed them with a mixture of domestic wastewater and electroplating wastewater. They obtained a COD removal of $79 \%$, while sulfate reduction showed the same behavior as COD. They also found 96-99\% removal of the applied nickel in these anaerobic filters. The critical ORL for the production of sulfide in amount higher than that required to precipitate the metal of interest as the metal sulfide, was 0.35 $\mathrm{kg} \mathrm{COD} / \mathrm{m}^{3} / \mathrm{d}$. However, the authors pointed out that above this OLR, the removal of the metal of interest, $\mathrm{Ni}$, was within an acceptable percentage, suggesting that some other removal processes may have taken place, such as bio-adsorption or precipitation by other ions in the system. It is important to note that the deficiency of sulfide in the effluent was 
overcome with an increase in the OLR, showing that the failure of the system was due to low organic content and not due to the toxicity of the metals in the plating waste.

El Bayoumy et al. (1999b) listed the advantages of metal sulfide precipitation over other methods as high efficiencies, production of lower sludge volume as compared with chemical precipitation, low solubility products and less tendency to resolubilize. The authors referred to the work of Dvorak et al. (1992) who used biological reactors in order to remove metals by means of sulfide precipitation with the sulfide produced by SRB, obtaining removals above $90 \%$. They observed that the height of the reactor in which complete removal occurred depended on the influent metal concentration and that the rate of metal removal with height was relatively constant, with the consequent conclusion that, at low metal concentrations, the rate of sulfide production with height remained constant as well (El Bayoumy et al., 1999b).

Hao et al. (1996) pointed out that the metal toxicity depended on experimental conditions like cell concentration, presence of complexing agents, metal mixtures, $\mathrm{pH}$ and type of the system, e.g. batch, sequencing batch reactor, pure culture, etc. It has been stated that some metals may also be precipitated and/or physically entrapped within the biomass (Hao et al., 1996; El Bayoumy et al., 1999b). 


\subsection{Operational Conditions}

Various researchers have identified the optimum operating conditions for sulfide production by SRB. Wijaya (1993) showed that the optimum organic loading rate, OLR, and optimum phosphorous concentration for the SRB growth were $6 \mathrm{~kg} / \mathrm{d} / \mathrm{m}^{3}$ and $65 \mathrm{mg} / \mathrm{L}$ of $\mathrm{P}$, respectively. El Bayoumy et al. (1999b) carried out a study to establish the optimum conditions for maximizing sulfide production by SRB to remove heavy metals. The following conditions were suggested:

- Th O D to sulfates ratio between 1.5 and 2.25 .

- OLR of o hy $C$ O D. $/ \mathrm{d} / \mathrm{m}^{3}$ or higher, assuming COD:Th.O.D. $=1$.

- Nitrogen loading of $0.3-0.7 \mathrm{~kg} \mathrm{NH} / \mathrm{N} / \mathrm{d} / \mathrm{m}^{3}$.

- Phosphorus loading of $0.06 \mathrm{~kg} \mathrm{P} / \mathrm{d} / \mathrm{m}^{3}$.

- Optimum Th O D.:N:P of 100:5:1.

- Hydraulic retention time, HRT, equal to or higher than $12 \mathrm{~h}$, with a corresponding upflow velocity of $2.4 \mathrm{~m} / \mathrm{h}$.

The authors reported an ultimate sulfide concentration of $140 \mathrm{mg} / \mathrm{L}$ under these conditions. They also observed a linear increase in TOC removal with HRT, and this removal was maintained at about $50-60 \%$ until complete failure of the reactor occurred at critical metal loadings (El Bayoumy et al., 1999b). It was pointed out that the sulfide production showed an increase with an increase in the total nitrogen concentration up to about $250 \mathrm{mg} \mathrm{NH}-\mathrm{N} / \mathrm{L}$ and it started to decrease at nitrogen concentrations between 250- 
$600 \mathrm{mg} \mathrm{NH} 4-\mathrm{N} / \mathrm{L}$. Higher nitrogen concentrations caused adverse effects. However, that was not the case for phosphorus when concentrations above $50 \mathrm{mg}$ of $\mathrm{P} / \mathrm{L}$ gave maximum sulfide production (El Bayoumy et al., 1999b).

Okabe and Characklis (1991) reported that the limiting $C$ to $P$ ratio (w/w) for growth of $D$. desulfuricans was in the range of $400: 1-800: 1$. They also reported a limiting $C$ to $N$ ratio $(w / w)$ for $D$. desulfuricans to be $45: 1-120: 1$, which was higher than that for an aerobic mixed population because $D$. desulfuricans partially oxidized lactate to acetate and $\mathrm{CO}_{2}$. Thus, cell production from substrate was approximately 10 times less than in aerobic systems and consequently nitrogen requirements were 10 times less. Hao et al. (1996) reported that sulfate and organic matter were used in a ratio of 2 to 1 , but it was a function of the organic matter to be degraded. 


\section{CHAPTER 3. EXPERIMENTAL PROCEDURE}

\subsection{Experimental Set-Up}

The following set-ups were used during this study:

Phase I. Growth of sulfate reducing bacteria in three $2 \mathrm{~L}$ parallel reactors.

Phase II. Batch studies in three $10 \mathrm{~L}$ parallel reactors.

Phase III. Continuous flow studies in three $10 \mathrm{~L}$ parallel reactors.

\subsubsection{Experimental Set-Up During Phase I}

The set-up for the first experimental phase consisted of three batch reactors, one of which was filled with $15.9 \mathrm{~mm}$ polypropylene pall rings with a porosity of $90 \%$ to provide a void volume of $1.7 \mathrm{~L}$. The other two reactors were used without any packing material and the void volume of these reactors was $1.9 \mathrm{~L}$. The batch reactors were constructed from 2 L Erlenmeyer flasks, capped and sealed with rubber stoppers, with one outlet for gas venting. The reactors were covered with aluminum foil to prevent any photosynthetic growth. Figure 3.1 shows the experimental set-up during Phase I.

All the three reactors were filled with feed solutions, with the composition established by El Bayoumy (1997) and shown in Table 3.1. The feed was based on $1 \mathrm{~d}$ and $4 \mathrm{~d}$ of retention time and the following optimum loading conditions based on stoichiometric equations: 


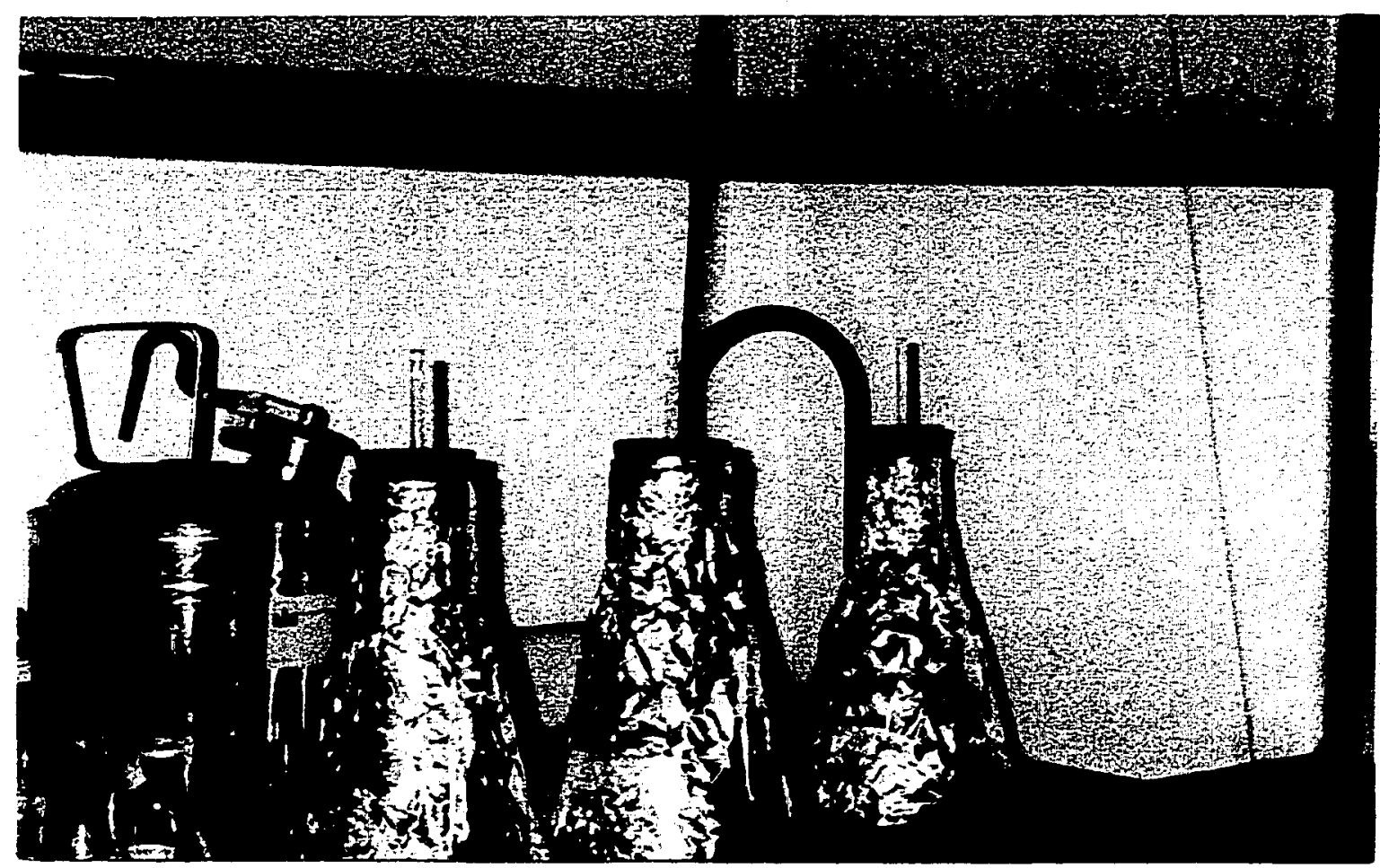

Figure 3.1 Experimental Set-Up During Phase I 
- $O L R=6 \mathrm{~kg} / \mathrm{d} / \mathrm{m}^{3}$.

- Th.O.D. $(g / L)=O L R^{*} H R T$

- $\quad$ Lactic Acid $(\mathrm{g} / \mathrm{L})=$ Th.O.D. $/ 1.07$

- $\mathrm{NaOH}(\mathrm{g} / \mathrm{L})=0.44 *$ Lactic Acid

- $\mathrm{SO}_{4}{ }^{2-}(\mathrm{g} / \mathrm{L})=$ Th.O.D. $/ 2$

- $\quad \mathrm{N}(\mathrm{g} / \mathrm{L})=$ Th.O.D. $/ 20$

- $P(g / L)=T h \cdot O \cdot D \cdot / 100$

The reactors were seeded with a sulfide-smelling wastewater sample collected from the West Windsor Wastewater Treatment Plant. The wastewater sample had a black color, rotten egg odor. $\mathrm{pH}$ of 70 and $100 \mathrm{~mL}$ were added to each reactor to provide the SRB strain, which was confirmed by the SRB counting test. The mixed bacterial culture in wastewater was preterred over the pure SRB culture, because in actual treatment process, the industrial wastewater will contain a mixed culture. Deionized water was used for the preparation of the wilutions. except for the third reactor in which tap water was used for comparison

\subsubsection{Experimental Set-l'p During Phase II}

\subsubsection{Reactors}

Three parallel transparent plexiglass $10 \mathrm{~L}$ reactors were used in batch mode. Each reactor had the following compunents 
1. Cylindrical reactors with an overall height of $1300 \mathrm{~mm}$ and an internal diameter of $102 \mathrm{~mm}$. These reactors were kept inside a closed light-tight chamber made of dark gray polyvinyl chloride (PVC) material.

2. Connecting plastic tubes

3. Three sampling ports equally spaced at $300 \mathrm{~mm}$ to collect samples for analysis at different heights.

Table 3.1 Batch Substrate Composition A for Phase I

\begin{tabular}{|c|c|c|}
\hline 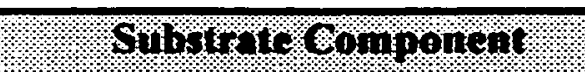 & IdPRT & 4dRI \\
\hline \multicolumn{3}{|l|}{ Reactor I, II and III } \\
\hline Lactic Acid $(\mathrm{g} / \mathrm{L})$ & 5.57 & 22.26 \\
\hline $\mathrm{NaOH}(\mathrm{g} / \mathrm{L})$ & 2.45 & 9.80 \\
\hline $\mathrm{MgSO}_{4}{ }^{*} 7 \mathrm{H}_{2} \mathrm{O}(\mathrm{g} / \mathrm{L})=2.56^{*} \mathrm{SO}_{4}$ & 7.68 & 30.72 \\
\hline $\mathrm{NH}_{4} \mathrm{Cl}(\mathrm{g} / \mathrm{L})=3.78 * \mathrm{~N}$ & 1.13 & 4.54 \\
\hline $\mathrm{KH}_{2} \mathrm{PO}_{4}(\mathrm{~g} / \mathrm{L})=(4.387 / 4)^{*} \mathrm{P}$ & 0.065 & 0.26 \\
\hline $\mathrm{K}_{2} \mathrm{HPO}_{4}(\mathrm{~g} / \mathrm{L})=4^{*} \mathrm{KH}_{2} \mathrm{PO}_{4}$ & 0.26 & 1.05 \\
\hline
\end{tabular}

Reactor I. Packed. Deionized water for dilution.

Reactor II. Non-packed. Deionized water for dilution.

Reactor III. Non-packed. Tap water for dilution.

The experiments were conducted at room temperature $19-25^{\circ} \mathrm{C}$. Initially, two of the reactors, Reactor I and III, were filled with $15.9 \mathrm{~mm}$ polypropylene pall rings with a porosity of $90 \%$ to provide a void volume of $9.09 \mathrm{~L}$, while the other reactor, non-packed, 
had a void volume of $10.1 \mathrm{~L}$. However, later on, it was decided to remove the packing material from Reactor III.

\subsubsection{Seed Material}

Once the average concentration of sulfide in Phase I had reached $100 \mathrm{mg} / \mathrm{L}$, the sediment from Reactor II was used as a seed during the set up for Phases II and Phase III. The $10 \mathrm{~L}$ reactors were inoculated with $200 \mathrm{~mL}$ of the seed culture with a VSS concentration of $4300 \mathrm{mg} / \mathrm{L}$ and a VSS to SS ratio of 0.76 . This culture showed the approximate concentration of SRB of $10^{6}$ cells $/ \mathrm{mL}$ when tested with an Immunoassay Test Kit for the detection of SRB.

\subsubsection{Media}

Two types of substrate composition were used during this stage:

1. Batch substrate composition $\mathbf{A}$ for Phase II as shown in Table 3.1 for 4 days of retention time. Final $\mathrm{pH}=7.0 \pm 0.1$

2. Batch substrate composition $B$ for Phase II as shown in Table 3.2. Final $\mathrm{pH}=$ $7.0 \pm 0.1$

The change in substrate composition and its sequence is described in the experimental procedure section. 
Table 3.2 Batch Substrate Composition B for Phase I

\begin{tabular}{|c|c|c|}
\hline 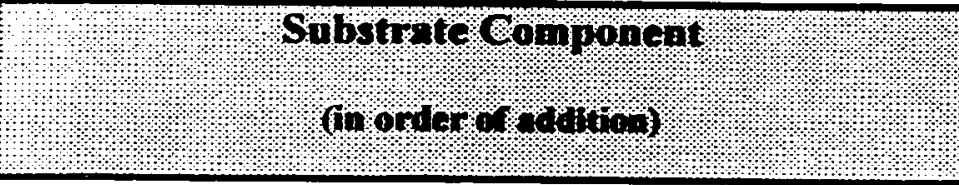 & 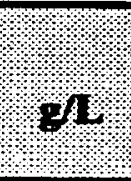 & (2. \\
\hline $\mathrm{NaOH}$ & 1.98 & \\
\hline Lactic Acid & 4.5 & 4.85 as Th.O.D. \\
\hline Sodium sulfate $\mathrm{Na}_{2} \mathrm{SO}_{4}$ & 2.36 & 1.6 as $\mathrm{SO}_{4}$ \\
\hline Ammonium Sulfate $\left(\mathrm{NH}_{4}\right)_{2} \mathrm{SO}_{4}$ & 1.14 & 0.2425 as $\mathrm{N}, 0.829$ as $\mathrm{SO}_{4}$ \\
\hline Potassium Di-hydrogen Phosphate $\left(\mathrm{KH}_{2} \mathrm{PO}_{4}\right)$ & 0.07 & 0.02 as $\mathbf{P}$ \\
\hline Potassium hydrogen Phosphate $\left(\mathrm{K}_{2} \mathrm{HPO}_{4}\right)$ & 0.18 & 0.0285 as $\mathrm{P}$ \\
\hline $\mathrm{MgSO}_{4} \cdot 7 \mathrm{H}_{2} \mathrm{O}$ & 0.03 & \\
\hline $\mathrm{CaCl}_{2} * 2 \mathrm{H}_{2} \mathrm{O}$ & 0.04 & \\
\hline SOLUTION OF LOW CONCENTRATION COMPOUNDS & & \\
\hline $\mathrm{FeSO}_{4} * 7 \mathrm{H}_{2} \mathrm{O}$ & 0.004 & \\
\hline $\mathrm{NiSO}_{4} * 6 \mathrm{H}_{2} \mathrm{O}$ & 0.009 & \\
\hline $\mathrm{CuSO}_{4} * 5 \mathrm{H}_{2} \mathrm{O}$ & 0.008 & \\
\hline $\mathrm{ZnSO}_{4} * 7 \mathrm{H}_{2} \mathrm{O}$ & 0.009 & \\
\hline $\mathrm{MnSO}_{4}{ }^{*} \mathrm{H}_{2} \mathrm{O}$ & 0.006 & \\
\hline $\mathrm{H}_{3} \mathrm{BO}_{3}$ & 0.01 & \\
\hline $\mathrm{CoCl}_{2} * 6 \mathrm{H}_{2} \mathrm{O}$ & 0.008 & \\
\hline Trace elements: $\mathrm{Fe}, \mathrm{Ni}, \mathrm{Cu}, \mathrm{Zn}, \mathrm{Mn}, \mathrm{B}, \mathrm{Co}$ & 0.002 & \\
\hline
\end{tabular}




\subsubsection{Experimental Set-Up During Phase III}

\subsubsection{Reactors}

Three parallel plexiglass UA reactors were used in continuous flow mode. Each reactor had the following components:

1. Feed container. The substrate was pumped from a glass or plastic container, stirred by a magnetic or suitable device, to the bottom inlet of the reactor by means of a variable speed peristaltic pump. These pumps were calibrated at the beginning of the experiment and checked every 5 days by measuring the time required to collect a known volume of effluent from the reactor.

2. UA reactors. The transparent plexiglass reactors were kept inside a closed lighttight chamber made of dark gray polyvinyl chloride (PVC) material to avoid any photosynthetic sulfur bacteria growth that could disturb the desired environment in the reactors. All reactors used had the following dimensions:

Overall Height: $1300 \mathrm{~mm}$

Distance between inlet and outlet: $1235 \mathrm{~mm}$

Internal diameter: $102 \mathrm{~mm}$

3. Effluent Glass Sampler Unit. The effluent sampler units were made of glass and had the following dimensions:

Height: $250 \mathrm{~mm}$

Internal Diameter: $50 \mathrm{~mm}$ 
These sampler containers had two controlled openings: one in the upper side of the unit for continuous withdrawal of reactor's effluent to the drain system and another one for collecting sample at the bottom of the unit.

4. Connecting Plastic Tubes.

5. Three sampling ports. Each reactor had three outlet ports, equally spaced at 300 $\mathrm{mm}$, to collect samples for analysis at different heights.

Figure 3.2 shows the configuration of the reactors while Figures 3.3 and 3.4 show the actual experimental set up for Phase III.

The experiments were conducted at room temperature $19-25^{\circ} \mathrm{C}$, and the feed solutions were prepared daily to prevent any degradation, or in some cases, they were stored at $4^{\circ} \mathrm{C}$ and then warmed up before use. An anaerobic environment was always maintained. The dissolved oxygen concentration in the effluent was always less than $0.5 \mathrm{mg} / \mathrm{L}$, which is below the critical dissolved oxygen concentration of $1 \mathrm{mg} / \mathrm{L}$ for sulfate reduction (Hao et al., 1996).

One of the reactors was filled with $15.9 \mathrm{~mm}$ polypropylene pall rings with a porosity of $90 \%$ to provide a void volume of $9.09 \mathrm{~L}$. The characteristics of the packing material are presented in Table 3.3. The reactors were kept air-tight by using rubber stoppers and screws to control and close all the openings, and also were kept inside a closed light-tight dark gray PVC chamber during operation, except during sampling, to prevent the photosynthetic sulfur bacteria growth and consequently to prevent any changes in the desired environment inside the reactors. 


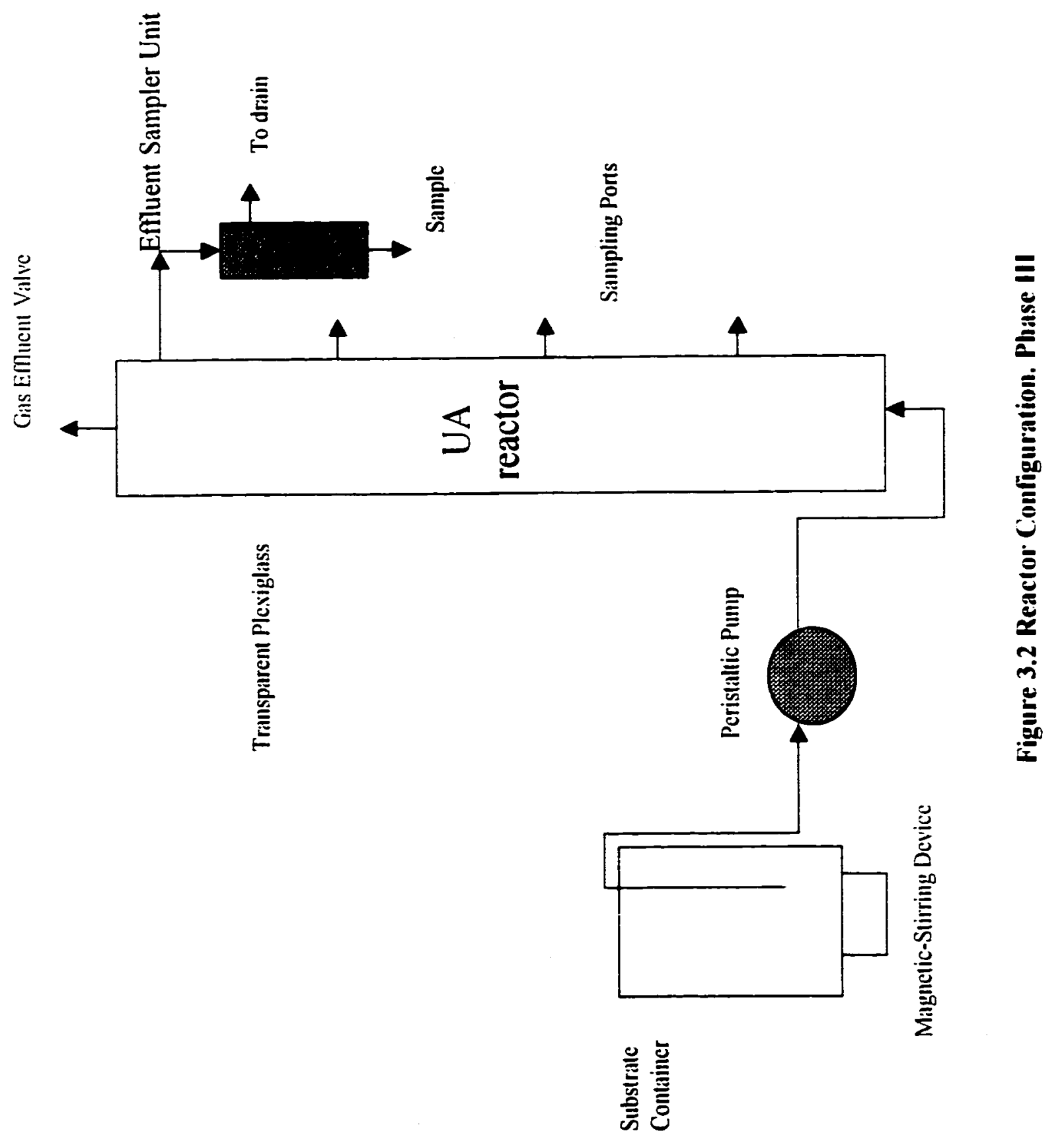




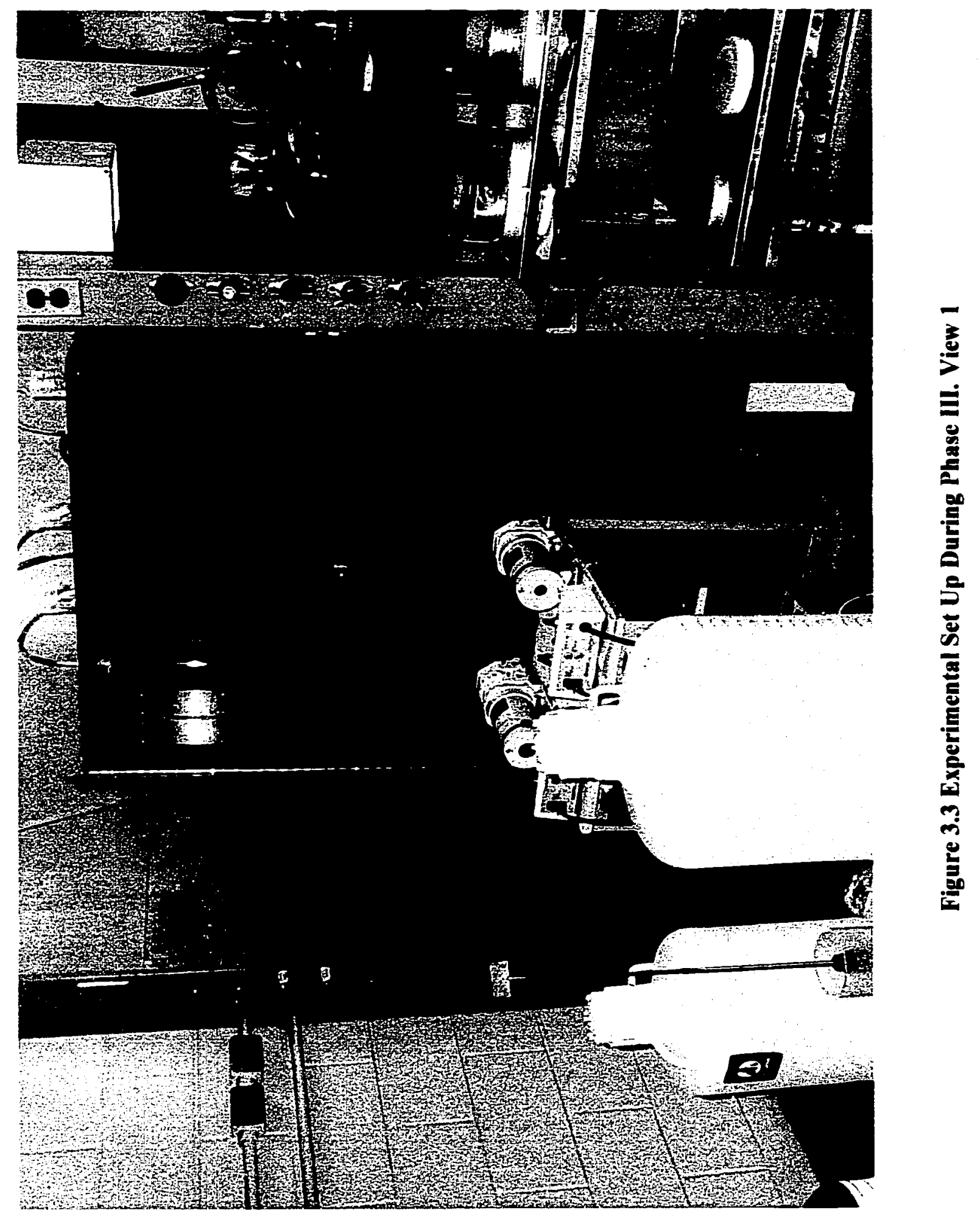




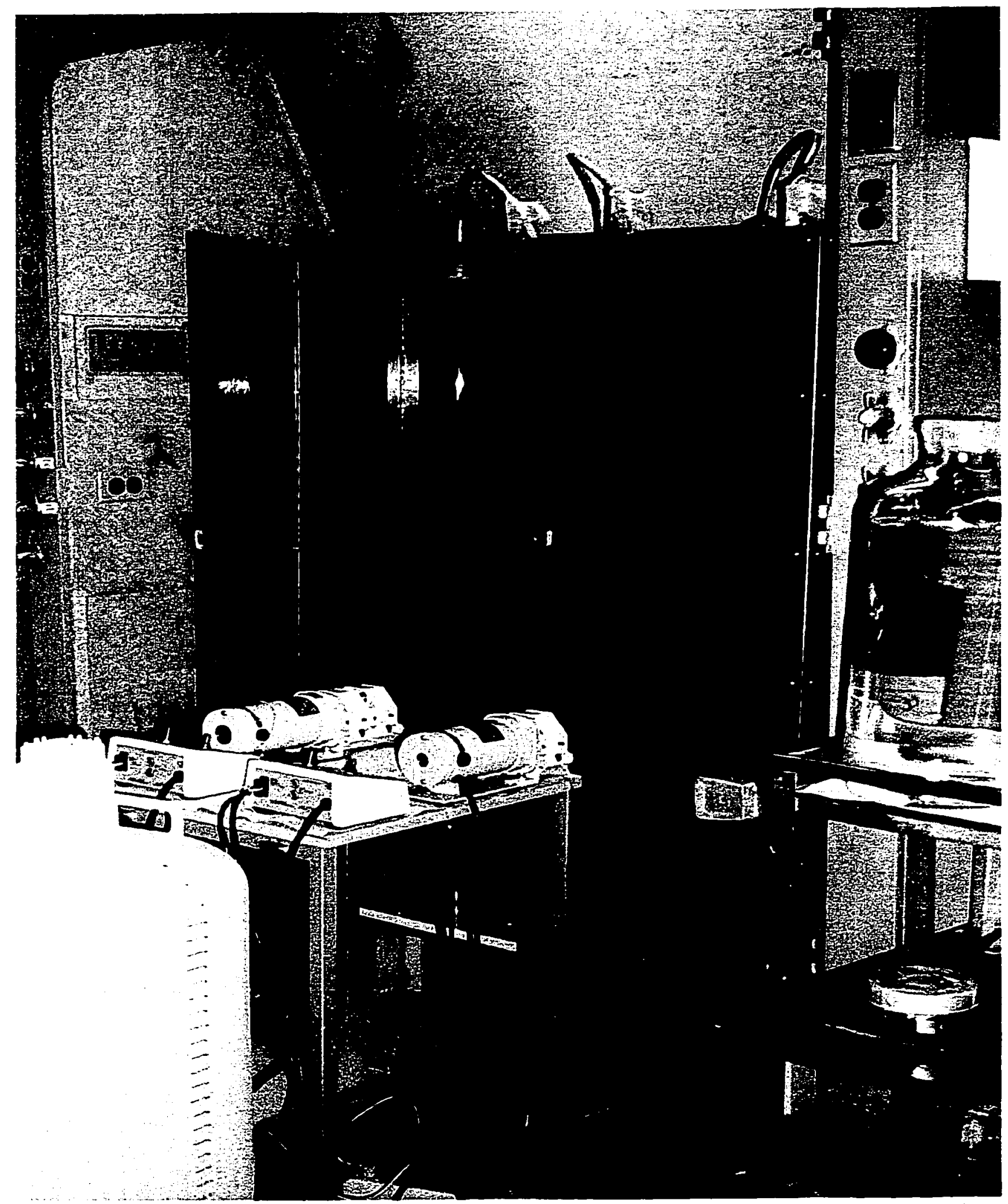

Figure 3.4 Experimental Set Uf During Phase III. View 2 
Table 3.3 Packing Material Characteristics

\begin{tabular}{|l|c|}
\hline \multicolumn{1}{|c|}{ Type } & Polypropylene Fall Rings \\
\hline Size (mm) & 15.9 \\
\hline Surface Area $\left(\mathrm{mm}^{2} / \mathrm{mm}^{3}\right)$ & 10.8 \\
\hline Free Space $(\%)$ & 90 \\
\hline
\end{tabular}

\subsubsection{Seed Material}

Since the same reactors operated during Phase II were used for Phase III, no seeding procedure was followed. From the sulfide concentration obtained in Phase II it could be seen that an acclimatized SRB culture was present in the reactors to start the continuous mode.

\subsubsection{Media}

Initially, the $10 \mathrm{~L}$ reactors were fed under batch conditions with the medium described in Table 3.2. Once the sulfide concentration had reached $100 \mathrm{mg} / \mathrm{L}$, the continuous flow mode was resumed and the substrate composition, shown in Table 3.4, was defined depending on the organic loading rate, OLR, and hydraulic retention time, HRT. 
Table 3.4 Substrate Composition for Continuous Flow Mode

\begin{tabular}{|c|c|c|c|c|c|c|c|c|}
\hline FRT (h) & 5. & 65 & $10 \%$ & $\overline{10}$ & $\overline{19}$ & 20 & 30. & 50 \\
\hline \multicolumn{9}{|l|}{$\begin{array}{c}\text { Substrate } \\
\text { Component } \\
(\mathrm{g} / \mathrm{L})\end{array}$} \\
\hline Lactic Acid & 1.16 & 1.74 & 4.64 & 2.32 & 5.57 & 4.64 & 6.96 & 11.60 \\
\hline $\mathrm{NaOH}$ & 0.51 & 0.77 & 2.04 & 1.02 & 2.45 & 2.04 & 3.06 & 5.1 \\
\hline $\mathrm{SO}_{4}$ & 0.63 & 0.94 & 2.50 & 1.25 & 3.00 & 2.50 & 3.75 & 6.25 \\
\hline $\mathrm{Na}_{2} \mathrm{SO}_{4}$ & 0.58 & 0.87 & 2.33 & 1.17 & 2.80 & 2.33 & 2.41 & 5.83 \\
\hline $\mathrm{MgSO}_{4} * 7 \mathrm{H}_{2} \mathrm{O}$ & 0.04 & 0.06 & 0.17 & 0.08 & 0.20 & 0.17 & 0.25 & 0.42 \\
\hline $\mathrm{CaCl}_{2}=2 \mathrm{H}_{2} \mathrm{O}$ & 003 & 0.03 & 0.03 & 0.03 & 0.03 & 0.03 & 0.03 & 0.03 \\
\hline$x$ & 006 & 0.09 & 0.25 & 0.13 & 0.30 & 0.25 & 0.38 & 0.63 \\
\hline$\left(\mathrm{NH}_{4}\right): \mathrm{SO}_{4}$ & 0.29 & 0.44 & 1.18 & 0.59 & 1.41 & 1.18 & 1.77 & 2.95 \\
\hline $\mathbf{P}$ & 0.01 & $\overline{0.02}$ & 0.05 & 0.03 & 0.06 & 0.05 & 0.08 & 0.13 \\
\hline $\mathrm{KH}_{2} \mathrm{PO}_{4}$ & 0018 & 0.027 & 0.073 & 0.037 & 0.088 & 0.073 & 0.110 & 0.183 \\
\hline $\mathrm{K}_{2} \mathrm{HPO}_{4}$ & 0047 & 0.07 & 0.187 & 0.094 & 0.225 & 0.187 & 0.281 & 0.469 \\
\hline $\begin{array}{c}\text { Trace elements } \\
\mathrm{Fe}, \mathrm{Ni}, \mathrm{Cu}, \mathrm{Zn} . \mathrm{M} \text { n. } \\
\mathrm{B}, \mathrm{Co} \\
\end{array}$ & 0.002 & 0.002 & 0.002 & 0.002 & 0.002 & 0.002 & 0.002 & 0.002 \\
\hline Parameter & 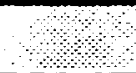 & & 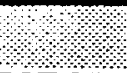 & & (:- & & & 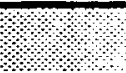 \\
\hline Flow L/d & 48.5 & 32.3 & 24.2 & 24.2 & 20.2 & 12.1 & 8.1 & 4.9 \\
\hline OLR $\left(\mathrm{kg} / \mathrm{d} / \mathrm{m}^{3}\right)$ & 6 & 6 & 12 & 6 & 12 & 6 & 6 & 6 \\
\hline Th.O.D. (g/L) & 1.25 & 1.88 & 5 & 2.50 & 6 & 5.00 & 7.50 & 12.50 \\
\hline Th.O.D.: $\mathrm{SO}_{4}$ & 2 & 2 & 2 & 2 & 2 & 2 & 2 & 2 \\
\hline Th.O.D.: N: P & $100: 5: 1$ & $100: 5: 1$ & 100:5:1 & 100:5:1 & $100: 5: 1$ & $100: 5: 1$ & $100: 5: 1$ & $100: 5: 1$ \\
\hline $\mathrm{KH}_{2} \mathrm{PO}_{4}: \mathrm{K}_{2} \mathrm{HPO}_{4}$ & $1: 2$ & $1: 2$ & $1: 2$ & $1: 2$ & $1: 2$ & $1: 2$ & $1: 2$ & $1: 2$ \\
\hline
\end{tabular}


Lactic acid was used as the carbon source, and sodium sulfate and ammonium sulfate were used as the sulfate sources. The influent $\mathrm{pH}$ was $7.0 \pm 0.1$. The Th.O.D.:sulfate and Th.O.D.:N:P were always kept at $2: 1$ and 100:5:1, respectively. The synthetic substrates were prepared daily and each feed tank was mixed continuously with a magnetic stirrer or any other suitable device.

\subsection{Experimental Procedure}

\subsubsection{Experimental Procedure. Phase I}

The main objective of this phase was to grow the sulfate reducing bacteria under batch conditions in order to use the strain to seed the $10 \mathrm{~L}$ reactors for Phases II and III. A healthy culture of the bacteria was indicated by the sulfide concentrations of $120-140$ mg/L obsered in prewıus studies (Wijaya, 1993; El Bayoumy, 1997).

In order to grow the SRB bacteria, each third day $15 \%$ of the volume of the $2 \mathrm{~L}$ reactors was replaced with iresh substrate solution and each week an analysis of sulfate, sulfide, pH and ORP "ss performed. The liquid content was completely mixed each time after refilling. The dilution water used in feeds for Reactors I and II was deionized water, while for Reactor III it was tap water.

This procedure was followed for 38 days. For the next 18 days the frequency of feeding was each third and fourth day with a weekly analysis. Then, for a week, the reactors were fed every second das After these 63 days. the feeding was done each 8 days but the 
substrate was concentrated, corresponding to

4 days of retention time. Also, deionized water was used for all substrate solutions. The reactors were covered with aluminum foil in order to eliminate light coming through. This was continued for additional 45 days but no analyses were done during this time.

This sequence permitted to achieve an average concentration of $100 \mathrm{mg} / \mathrm{L}$ for the Reactor II, which was conserved as the seed reactor for the subsequent studies. This concentration was checked every week and the $\mathrm{pH}$ was always kept at about 7.0 . The feedings were done every 8 days, with a substrate solution based on 4 day of retention time. This substrate composition remained the same, until a change in substrate composition was made during the second phase of experiments. The new substrate composition is shown in Table 3.2.

\subsubsection{Experimental Procedure. Phase II}

A set of three $10 \mathrm{~L}$ parallel reactors was filled with the substrate with composition shown in Table 3.1 for a retention time of 4 days and was operated under batch conditions for 2 weeks. This was done in an attempt to grow the old strain of bacteria remaining from the previous experiments (El Bayoumy, 1997). A stable sulfide concentration in the three 10 $\mathrm{L}$ reactors was reached through different sequences of withdrawal-analysis-recharge.

$1^{\text {st }}$ sequence. Each reactor was inoculated with $200 \mathrm{~mL}$ of the sludge from Reactor II Phase I, which was equivalent to a VSS mass of $860 \mathrm{mg}$. These $200 \mathrm{~mL}$ of inoculum 
were mixed with $1.3 \mathrm{~L}$ of feed solution, described in Table 3.1 , for a retention time of 4 days. Each eight days, $1.5 \mathrm{~L}$ of reactor's contents was withdrawn from the $3^{\text {rd }}$ port of the reactor for analysis of sulfide and recharged with an equivalent volume of fresh substrate solution. This was continued for 32 consecutive days.

$2^{\text {nd }}$ sequence. Each four days, $1.5 \mathrm{~L}$ of reactor's contents was withdrawn from the $3^{\text {rd }}$ port of the reactor for analysis of sulfide and then recharged with an equivalent volume of fresh substrate solution. This continued for another 24 days. The packing material was removed from Reactor III on Day 44.

$3^{\text {rd }}$ sequence. In order to keep the bacteria active, a weekly withdrawal/recharge was done during 35 days and the sulfide concentration was monitored as well. At the end of this period and during four consecutive days with no recharges, analyses of sulfide, sulfate, VSS and ORP/pH were performed.

$4^{\text {th }}$ sequence. After the above sequence, it was decided to leave the reactors without any withdrawal or recharge for 12 days, and start the fourth sequence with a new formulation of substrate as presented in Table 3.2 .

The sequence started with the withdrawal of $1.5 \mathrm{~L}$ of reactor's contents for analyses of sulfide, sulfate, VSS and pH/ORP, and recharge with the same volume with new substrate formulation. After 6 days of adaptation to the new formulation, the procedure of withdrawal-analysis-recharge was performed again for each column every third or fifth day. This was continued until 5 analyses for sulfide and VSS per reactor were done. 
Analyses for ammonia-nitrogen and soluble chemical oxygen demand were also performed in between to have a perspective of the conditions of the reactors with respect to nitrogen content and consumption of organic matter.

Once the sulfide concentration reached $100 \mathrm{mg} / \mathrm{L}$ in all reactors, the continuous flow mode was started with the medium, shown in Table 3.4, for the desired organic loading rate, OLR, and hydraulic retention time, HRT.

\subsubsection{Experimental Procedure. Phase III}

The objectives of this phase were:

1. Determine the effect of packing material in comparison with suspended growth of SRB in an I pllow Anaerobic Reactor.

2. Establish the effect of the hydraulic retention time on the maximum sulfide concentratuin in the reactor.

In order to es aluate these parameters, two $10 \mathrm{~L}$ parallel reactors, one packed and the other non-pached. were nun under identical conditions, while a third reactor non-packed was operated at a lower hydraulic retention time. The reactors were operated for a period of 120 days

In all the three reactors. a substrate with lactate as the sole carbon source was fed. Table 3.4 shows the compovioun of this substrate in which the concentration of lactic acid was based on its theoretsical oỵgen demand, Th.O.D., and the hydraulic retention time tested. 
The Th.O.D.:sulfate and Th.O.D.:N:P were always kept as $2: 1$ and 100:5:1, respectively. The value of Th.O.D. was maintained at the stoichiometric value to allow complete organic removal through sulfate reduction. The organic loading rate was varied between 6 and $12 \mathrm{~kg} / \mathrm{d} / \mathrm{m}^{3}$ under different operating conditions as shown in Table 3.5 .

Sulfide production was used as indicator of the SRB activity, VSS as estimation of growth of biomass and $\mathrm{pH}$ and ORP were measured to control the reactors' performance. These analyses were performed both on the effluent and a sample from the first port, $300 \mathrm{~mm}$ above the bottom of the reactor, until a steady state condition had been reached in each reactor, which generally occurred within 8 to 10 times the HRT. When the system had become stable, similar analyses were carried out on samples from the second and third ports. For each new set of conditions, it was necessary to change tubing in the system. Pump calibration was checked (Appendix A) and fresh feed solutions were used.

Table 3.5 UA Reactors Operating Conditions for Phase III

\begin{tabular}{|c|c|c|c|c|c|c|c|c|}
\hline $\begin{array}{c}\text { Reactor } \\
\text { Void volume } \\
\text { (L) }\end{array}$ & $\begin{array}{l}\text { Packing } \\
\text { Material }\end{array}$ & $\begin{array}{r}\text { Set } 1 \\
\text { HRT } \\
\text { (h) }\end{array}$ & $\begin{array}{l}\text { Set } 2 \\
\text { HRT } \\
\text { (h) }\end{array}$ & $\begin{array}{r}\text { Set } 3 \\
\text { HRT } \\
\text { (h) }\end{array}$ & \multicolumn{2}{|c|}{$\begin{array}{c}\text { Set } 4 \\
\text { HRT } \\
\text { (h) }\end{array}$} & \multicolumn{2}{|c|}{$\begin{array}{c}\text { Set } 5 \\
\text { HRT } \\
\text { (b) }\end{array}$} \\
\hline $\begin{array}{c}\mathrm{I} \\
9.09 \mathrm{~L}\end{array}$ & $\begin{array}{c}\text { Poly-propylene } \\
\text { Pall Rings }\end{array}$ & 50 & 30 & 20 & NA & NA & NA & NA \\
\hline $\begin{array}{c}\text { II } \\
10.1 \mathrm{~L}\end{array}$ & None & 50 & 30 & 20 & $\overline{\mathbf{N A}}$ & 10 & 12 & 7.5 \\
\hline $\begin{array}{c}\text { III } \\
10.1 \mathrm{~L}\end{array}$ & None & 30 & 20 & 10 & 5 & $\overline{\mathrm{NA}}$ & $\mathbf{N A}$ & $\mathbf{N A}$ \\
\hline OLR & $/ \mathrm{d} / \mathrm{m}^{3}$ & 6 & 6 & 6 & 6 & 12 & 12 & 12 \\
\hline
\end{tabular}




\subsection{Analyses}

The analyses performed were:

a) Sulfide. Sulfide production was investigated for suitable representation of SRB activity. This parameter was measured over the entire length of the study. The concentration of $\mathrm{H}_{2} \mathrm{~S}$ in the biogas was not determined.

b) Volatile Suspended Solids, VSS. It was assumed that the VSS represented the biomass present in the reactor.

c) Sulfate. Sulfate was measured as an indicator of the total sulfate consumed in the sulfide production process.

d) $\mathrm{pH}$ and ORP. These tests were used as an indicator of the reactor's environmental conditions and as a controller of the reactor performance.

e) Dissolved COD. These tests were performed when the level of organic substrate had to be estimated. However, sulfate concentrations were used as an indicator of the dissolved COD used in the sulfide production process.

f) SRB count. SRB count was performed to detect the presence of SRB and the relative growth in the reactor.

All analytical procedures were performed according to the Standard Methods for the Examination of Water and Wastewater (APHA, 1995). 


\subsubsection{Sulfide}

In order to determine the total sulfide concentration in the liquid samples, the Iodometric Method (4500-S $\left.\mathrm{S}^{2-} \mathrm{F}\right)$ was used. This method is based on the titration of sulfide, which is oxidized by iodine in acid solution (APHA, 1995). The basic reactions are as follows (Jeffery et al., 1989):

Pretreatment step:

$$
\begin{gathered}
\mathrm{H}_{2} \mathrm{~S}+2 \mathrm{NaOH} \rightarrow \mathrm{S}^{2-}+2 \mathrm{H}_{2} \mathrm{O}+2 \mathrm{Na}^{-} \\
2 \mathrm{HS}^{-}+2 \mathrm{NaOH} \rightarrow \mathrm{S}^{2-}+2 \mathrm{H}_{2} \mathrm{O}+\mathrm{Na}^{-}
\end{gathered}
$$

$$
\mathrm{S}^{2-}+\mathrm{Zn}\left(\mathrm{C}_{2} \mathrm{H}_{3} \mathrm{O}_{2}\right)_{2}{ }^{*} 2 \mathrm{H}_{2} \mathrm{O} \rightarrow \mathrm{ZnS} \downarrow+2\left(\mathrm{C}_{2} \mathrm{H}_{3} \mathrm{O}_{2}\right)^{-}+2 \mathrm{H}_{2} \mathrm{O}
$$

Sulfide Oxidation: $\quad \mathrm{ZnS}+\mathrm{I}_{2}$ (dark brown) $\leftrightarrow \mathrm{Zn}^{2-}+\mathrm{S}^{2-}+2 \mathrm{I}^{-}$(colorless) $\ldots .3 .4$

Titration of excess of iodine: $\quad 2 \mathrm{~S}_{2} \mathrm{O}_{3}{ }^{2-}+\mathrm{I}_{3}{ }^{-} \leftrightarrow \mathrm{S}_{4} \mathrm{O}_{6}{ }^{2-}+3 \mathrm{I}^{-}$

This method suffers interference from reducing substances that react with iodine, including thiosulfate, sulfite and various organic compounds. In order to suppress these interferences and to concentrate sulfide, a sample pretreatment was done by the precipitation of sulfide as $\mathrm{ZnS}$ with zinc acetate solution in alkaline medium $(\mathrm{pH}$ above 9.0) according to the standard procedure $4500-\mathrm{S}^{2-} \mathrm{C}$. The pretreated sample was filtrated and this precipitate was collected and dissolved in water, excess of iodine solution was added in acidic conditions and titrated with a standardized thiosulfate $\left(\mathrm{Na}_{2} \mathrm{~S}_{2} \mathrm{O}_{3}\right)$ solution. 
During this procedure, it is important to take samples with minimum aeration and analyze immediately. The use of fresh standardized solutions of iodine and thiosulfate is extremely important for the precision of the results. The $95 \%$ confidence level of this analysis was found to be $\pm 5 \%$ of the mean value as shown in Appendix C.

\subsubsection{Volatile Suspended Solids}

VSS were analyzed according to the Standard Method 2540 D (APHA, 1995). A liquid sample was filtered through a glass fiber filter of $1.5 \mu \mathrm{m}$ pore size, and the residue was dried to a constant mass at $103-105^{\circ} \mathrm{C}$. The retained mass on the filter paper showed the suspended solids. This dried residue was then ignited at $550^{\circ} \mathrm{C}$. The mass lost on ignition showed the volatile suspended solids. VSS were assumed to represent the biomass present in the reactor. The ratio of VSS to SS, on an average, was between 0.7 and 0.8 . The $95 \%$ confidence level of this analysis was found to be $\pm 8 \%$ of the mean value as shown in Appendix C.

\subsubsection{Sulfate}

Sulfate was analyzed according to the Standard Turbidimetric Method 4500- $\mathrm{SO}_{4}{ }^{2-} \mathrm{E}$ (APHA, 1995). The basic principle of the method was the precipitation of sulfate ion, $\mathrm{SO}_{4}{ }^{2-}$, in an acetic acid medium with barium chloride, $\mathrm{BaCl}_{2}$, forming barium sulfate crystals. The light absorbance of the resulting solution was measured by a Ratio/XR turbidimeter Hach Model 43900. In order to determine the $\mathrm{SO}_{4}{ }^{2-}$ concentration, iiie iNTU 
turbidity reading was compared with a standard curve prepared previously for different concentrations of standard sulfate solutions. The standard curve (see Appendix A) was prepared within a 0 to $40 \mathrm{mg} \mathrm{SO}_{4}{ }^{2-} / \mathrm{L}$ in order to keep method's accuracy and the stability of $\mathrm{BaSO}_{4}$ suspensions (APHA, 1995). Whenever the sulfate concentration in the liquid samples exceeded the range of the calibration curve, an appropriate dilution of samples was made.

\subsection{4 pH and ORP}

The oxidation-reduction potential was measured with an ORP meter, Orion Model 290A, with a combined electrode and a temperature probe. The reading was taken after $10 \mathrm{~min}$ or until the instrument had reached equilibrium. The ORP meter was calibrated using a solution of a known ORP value. The standard ORP solution consisted of $39.21 \mathrm{~g}$ $\mathrm{Fe}\left(\mathrm{NH}_{4}\right)_{2}\left(\mathrm{SO}_{4}\right)_{2} .6 \mathrm{H}_{2} \mathrm{O}, 48.22 \mathrm{~g} \mathrm{Fe}\left(\mathrm{NH}_{4}\right)\left(\mathrm{SO}_{4}\right)_{2} .12 \mathrm{H}_{2} \mathrm{O}, 56.2 \mathrm{~mL}$ of $\mathrm{H}_{2} \mathrm{SO}_{4}$, dissolved in IL of distilled water. The standard ORP of this solution is $467 \mathrm{mV}$ (APHA, 1995) and the actual ORP value obtained was $466 \mathrm{mV}$.

The $\mathrm{pH}$ was measured with a VWR Scientific Products $\mathrm{pH}$ meter Model 8100, which was calibrated each week with buffer solutions of $\mathrm{pH} 7.0$ and $\mathrm{pH} 10.0$.

\subsubsection{Soluble COD}

In order to determine the soluble Chemical Oxygen Demand in the liquid samples, the Closed Reflux Colorimetric Method (5220 D) was used. 
The soluble portion was obtained after filtering the liquid sample through a glass fiber filter. The chemical oxygen demand is considered to be a measure of the oxygen required for the chemical oxidation of organic matter. This is done by means of a strong chemical oxidant, in this case a mixture of chromic and sulfuric acid was used.

The oxygen consumed after digestion in reaction culture tubes, was measured at $600 \mathrm{~nm}$ with a spectrophotometer, Model Spectronic 20D+, from Spectronic Instruments. The absorbance reading was then compared with a standard curve. This standard curve was prepared from five potassium hydrogen phthalate standards with COD equivalents from 100 to $500 \mathrm{mg} \mathrm{O}_{2} / \mathrm{L}$.

As the liquid samples also contained sulfide, a correction was made to the observed COD value by using the stoichiometry of the sulfide oxidation and the sulfide concentration measured in the sample.

\subsubsection{Bacterial Count}

An Immunoassay Test Kit Rapid Check II supplied by Strategic Diagnostics Inc. Newark, Delaware USA was used for the SRB count. It used purified antibodies attached to small particles that captured the enzyme adenosine-5'-phosphosulfate (APS) reductase which is characteristic of all SRB strains. The resuits of the test are expressed as cells $/ \mathrm{mL}$. The analysis shows total cell count and does not differentiate between live and dead cells. Also, it does not account for cells that have ruptured.

The test results are ambient temperature dependent so that the proper procedure was followed depending on the ambient temperature during the analysis. 


\section{CHAPTER 4. DEVELOPMENT OF STOICHIOMETRIC AND KINETIC EQUATIONS}

In order to analyze and interpret the data, the following stoichiometric and kinetic equations were developed for this study.

\subsection{Stoichiometric Equations}

McCarty et al . (1969) had derived the following equations for organic compounds oxidation. sulfate reduction and bacterial cells synthesis considering, $\mathrm{C}_{5} \mathrm{H}_{7} \mathrm{O}_{2} \mathrm{~N}$ as its chemical formula

Oxidation Equation for Lactate (Electron Donor)

$$
\frac{1}{12} \mathrm{C}_{:} \mathrm{H}_{5} \mathrm{O}_{3}+\frac{1}{3} \mathrm{H}_{2} \mathrm{O} \rightarrow \frac{1}{6} \mathrm{CO}_{2}+\frac{1}{12} \mathrm{HCO}_{3}^{-}+\mathrm{H}^{-}+\overline{\mathrm{e}}
$$

assuming that all alkalinity is expressed as $\mathrm{HCO}_{3}{ }^{-}$, since the $\mathrm{pH}$ was kept at or below 7.0 (Peavy et al., 1985).

Reduction Equation for Sulfate (Electron Acceptor)

$$
\frac{1}{8} \mathrm{SO}_{4}{ }^{2-}+\mathrm{H}^{-}+\overline{\mathrm{e}} \rightarrow \frac{1}{2} \mathrm{H}_{2} \mathrm{O}+\frac{1}{8} \mathrm{~S}^{2-}
$$


Equation for Cell Synthesis

$$
\frac{1}{5} \mathrm{CO}_{2}+\frac{1}{20} \mathrm{HCO}_{3}^{-}+\frac{1}{20} \mathrm{NH}_{4}^{-}+\mathrm{H}^{+}+\overline{\mathrm{e}} \rightarrow \frac{1}{20} \mathrm{C}_{5} \mathrm{H}_{7} \mathrm{O}_{2} \mathrm{~N}+\frac{9}{20} \mathrm{H}_{2} \mathrm{O}
$$

For respiration, addition of Equations 4.1 and 4.2 gives:

$$
\frac{1}{12} \mathrm{C}_{3} \mathrm{H}_{5} \mathrm{O}_{3}{ }^{-}+\frac{1}{8} \mathrm{SO}_{4}{ }^{2-} \rightarrow \frac{1}{6} \mathrm{H}_{2} \mathrm{O}+\frac{1}{8} \mathrm{~S}^{2-}+\frac{1}{6} \mathrm{CO}_{2}+\frac{1}{12} \mathrm{HCO}_{3}^{-}
$$

For synthesis, addition of Equations 4.1 and 4.3 gives:

$$
\frac{1}{12} \mathrm{C}_{3} \mathrm{H}_{5} \mathrm{O}_{3}^{-}+\frac{1}{30} \mathrm{CO}_{2}+\frac{1}{20} \mathrm{NH}_{4}^{-} \rightarrow \frac{1}{20} \mathrm{C}_{5} \mathrm{H}_{7} \mathrm{O}_{2} \mathrm{~N}+\frac{7}{60} \mathrm{H}_{2} \mathrm{O}+\frac{1}{30} \mathrm{HCO}_{3}^{-}
$$

\subsection{Kinetic Model Equations}

For the continuous mode operation of three upflow anaerobic reactors, kinetic models were developed to obtain the rate of sulfide production under the operational conditions established in this study. Two types of reactors were considered: continuous (flow) stirred-tank, CSTR, and plug flow. Due to limited mixing observed in the experiments, only plug flow reactor models were developed as shown below. The calculations and assumptions for each model are explained in the following sections. 


\subsubsection{Kinetic Model I: Biomass Production Rate}

The following equation was used for biomass production rate:

$$
\frac{\mathrm{dX}}{\mathrm{dt}}=\mu \mathrm{X}
$$

Where,

$\mathrm{dX} / \mathrm{dt}=$ biomass production rate $[\mathrm{mg} / \mathrm{h} / \mathrm{L}]$

$\mu=$ specific growth rate $\left[h^{-1}\right]$

$\mathrm{X}=$ biomass concentration $[\mathrm{mg} / \mathrm{L}]$

As shown in Figure 4.1, a mass balance for biomass in a differential volume, $\Delta \mathrm{V}$, in the active reactor element was carried out as follows:

$\begin{aligned} & \text { Rate of } \\ & \text { Accumulation }\end{aligned}=\begin{gathered}\text { Rate of } \\ \text { Biomass Inflow }\end{gathered}-\begin{gathered}\text { Rate of } \\ \text { Biomass Outflow }\end{gathered}+\begin{gathered}\text { Rate of } \\ \text { Biomass Production }\end{gathered}$
or Rate of Accumulation $=\mathbf{Q X} \quad-\quad \mathrm{Q}\left(\mathrm{X}+\frac{\Delta \mathrm{X}}{\Delta \mathrm{h}} \Delta \mathrm{h}\right)+\mu \mathrm{X}$

Under steady state conditions, Rate of Accumulation $=0$ and $X=X_{s}$

After dividing by $\Delta \mathrm{V}=\mathbf{A} \Delta \mathrm{h}$,

$0=-\frac{Q}{A} \frac{\Delta X_{s}}{\Delta h}+\mu X_{s}$ 
when $\Delta \mathrm{h} \rightarrow 0$

$\frac{\mathrm{Q}}{\mathrm{A}} \frac{\mathrm{dX}}{\mathrm{dh}}=\mu \mathrm{X}_{\mathrm{s}}$

Integrating between active volume with depth $\mathrm{L}$ in which biomass concentration increased from $X_{\circ}$ to $X_{s}$,

$\int_{X_{0}}^{X_{0}} \frac{d X}{X_{V}}=\frac{A}{Q} \mu \int_{11}^{1} d h$

$\ln X_{s}-\ln X_{1}=\mu \frac{\mathcal{A} \cdot L}{Q}=\mu \frac{V_{\text {active }}}{Q}=\mu t_{d}$

or

$\ln X_{s}=\mu\left(\frac{V_{\text {acive }}}{Q}\right)+\ln X_{0}$

Where,

$\mathrm{X}_{\mathrm{o}}=$ inlet biomass concentration $[\mathrm{mg} / \mathrm{L}]$

$\mathrm{X}_{\mathrm{s}}=$ steady state biomass concentration $[\mathrm{mg} / \mathrm{L}]$

$V_{\text {active }}=$ active reactor's volume $\left[\mathrm{m}^{3}\right]$

$\mathrm{Q}=$ volumetric flow rate $\left[\mathrm{m}^{3} / \mathrm{h}\right]$

$t_{d}=$ hydraulic retention time in active volume $[h]=\frac{V_{\text {actuve }}}{Q}$

For collection and interpretation of results, VSS values were assumed to represent biomass concentration in the reactors. 


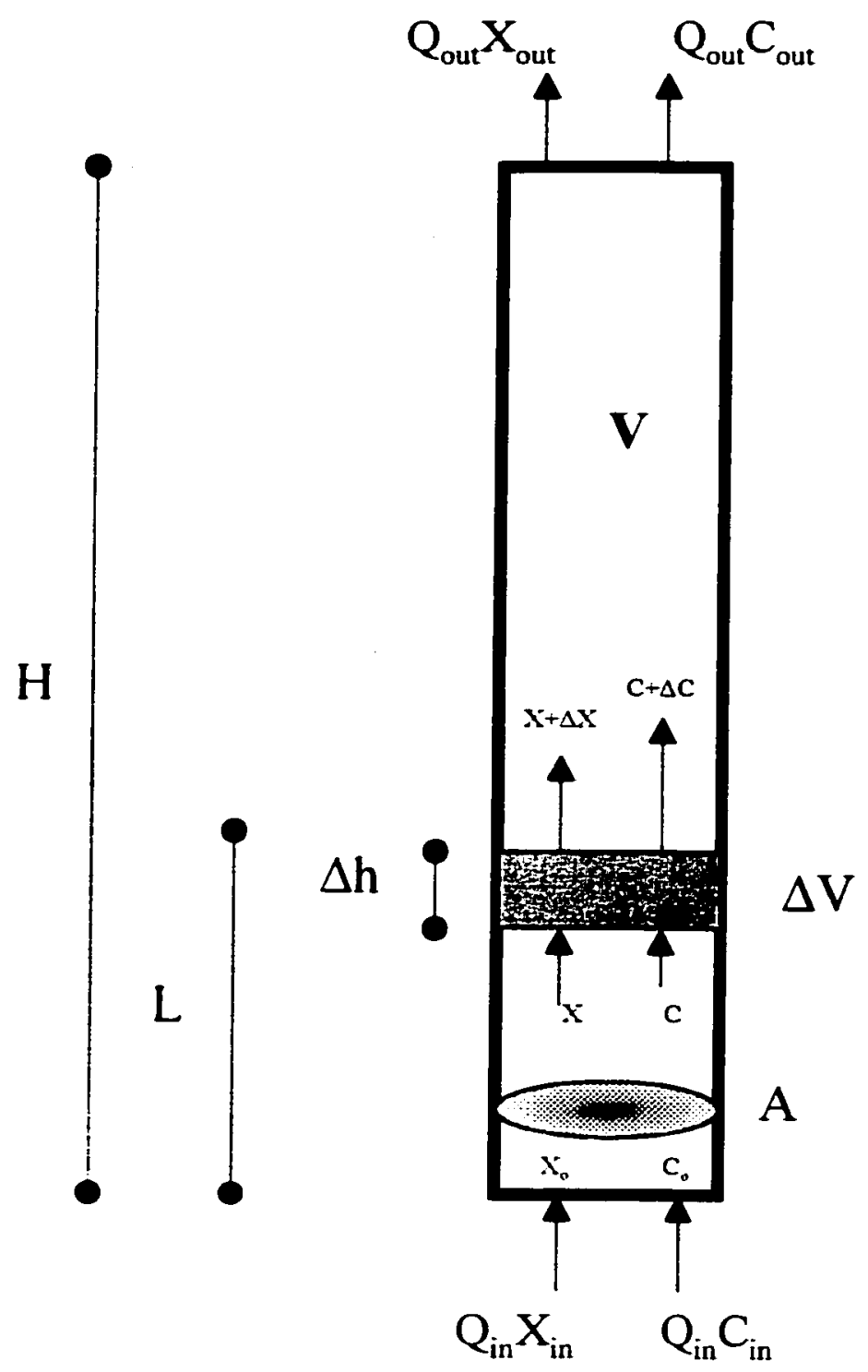

Figure 4.I MIass Balance Lay-Out in a Differential Volume Element 


\subsubsection{Kinetic Model I: Sulfide Production Rate}

The following equation was used for sulfide production rate:

$$
\frac{\mathrm{dC}}{\mathrm{dt}}=\mathrm{KC}
$$

Where,

$\mathrm{dC} / \mathrm{dt}=$ sulfide production rate $[\mathrm{mg} / \mathrm{h} / \mathrm{L}]$

$\mathrm{K}=$ rate constant $\left[\mathrm{h}^{-1}\right]$

$\mathrm{C}=$ sulfide concentration $[\mathrm{mg} / \mathrm{L}]$

A mass balance for sulfide in a differential volume, $\Delta \mathrm{V}$, in the active reactor element was carried out as follows:

$\begin{aligned} & \text { Rate of } \\ & \text { Accumulation }\end{aligned}=\begin{gathered}\text { Rate of } \\ \text { Sulfide Inflow }\end{gathered}-\begin{gathered}\text { Rate of } \\ \text { Sulfide Outflow }\end{gathered}+\quad \begin{gathered}\text { Rate of } \\ \text { Sulfide Production }\end{gathered}$
or Rate of Accumulation $=Q C-Q(C+\Delta C)+K C \Delta V$

Under steady state conditions, Rate of Accumulation $=0$ and $C=C_{s}$

After dividing by $\Delta \mathrm{V}=\mathrm{A} \Delta \mathrm{h}$,

$0=-\frac{Q}{A} \frac{\Delta C_{s}}{\Delta h}+K C_{s}$ 
When $\Delta h \rightarrow 0$

$$
0=-\frac{Q}{A} \frac{d C_{s}}{d h}+K C_{s}
$$

$\frac{\mathrm{Q}}{\mathrm{A}} \frac{\mathrm{dC}_{\mathrm{s}}}{\mathrm{dh}}=\mathrm{KC}_{\mathrm{s}}$

Integrating between active volume with depth $\mathrm{L}$ in which sulfide concentration increased from $C_{o}$ to $C_{s}$,

$$
\begin{aligned}
& \int_{c}^{C_{s}} \frac{d C_{s}}{C_{s}}=K \frac{A}{Q} \int_{1,}^{L} d h \\
& \ln \left[C_{s}\right]-\ln \left[C_{s}\right]=K \frac{A^{*} L}{Q}=K t_{d}
\end{aligned}
$$

or

$$
\ln C_{s}=K\left(\frac{V_{\text {active }}}{Q}\right)+\ln C_{n}
$$

Where,

$C_{0}=$ inlet sulfide concentration $[\mathrm{mg} / \mathrm{L}]$

$\mathrm{C}_{\mathrm{s}}=$ steady state sulfide concentration $[\mathrm{mg} / \mathrm{L}]$ 


\subsubsection{Kinetic Model III: Sulfide and Biomass Concentrations}

The following equation was used for sulfide production based on sulfide and biomass concentrations:

$$
\frac{d C}{d t}=K^{\prime} C X
$$

Where,

$\mathrm{dC} / \mathrm{dt}=$ sulfide production rate $[\mathrm{mg} / \mathrm{h} / \mathrm{L}]$

$\mathrm{K}^{\prime}=$ rate constant $\left[\mathrm{L} /\left(\mathrm{mg}^{*} \mathrm{~h}\right)\right]$

$\mathrm{C}=$ sulfide concentration $[\mathrm{mg} / \mathrm{L}]$

$\mathrm{X}=$ biomass concentration $[\mathrm{mg} / \mathrm{L}]$

A mass balance for sultide in a differential volume, $\Delta \mathrm{V}$, in the active reactor element was carried out as follows

$\begin{gathered}\text { Rate of } \\ \text { Accumulation }\end{gathered}$
$\begin{gathered}\text { Rate of } \\ \text { Sultide Inflow }\end{gathered}$ $\begin{gathered}\begin{array}{c}\text { Rate of } \\ \text { Sulfide Outflow }\end{array} \\ \text { Rate of Accumulation }\end{gathered}$

Under steady statc conditıons Rate of Accumulation $=0, X=X_{s}$ and $C=C_{s}$

After dividing by $\mathbf{s}= \pm \mathbf{S}$. 


$$
0=-\frac{Q}{A} \frac{\Delta C_{s}}{\Delta h}+K^{\prime} C_{s} X_{s}
$$

When $\Delta h \rightarrow 0$

$\frac{Q}{A} \frac{d C_{s}}{d h}=K^{\prime} C_{s} X_{s}$

Integrating between active volume with depth $\mathrm{L}$ in which sulfide concentration increased from $C_{o}$ to $C_{s}$,

$\int_{C_{0}}^{C_{s}} \frac{d C_{s}}{C_{s}}=K^{\prime} \overline{X_{s}} \frac{A}{Q} \int_{0}^{L} d h$

$\ln \left[C_{s}\right]-\ln \left[C_{o}\right]=K^{\prime} \overline{X_{s}} \frac{A^{*} L}{Q}=K^{\prime} \overline{X_{s}} t_{d}$

or

$$
\ln \mathrm{C}_{\mathrm{s}}=\mathrm{K}^{\prime} \overline{\mathrm{X}}_{\mathrm{s}}\left(\frac{\mathrm{V}_{\text {active }}}{\mathrm{Q}}\right)+\ln \mathrm{C}_{0}
$$

Where,

$\mathrm{C}_{\mathrm{o}}=$ initial sulfide concentration $[\mathrm{mg} / \mathrm{L}]$

$\overline{X_{s}}=$ average biomass concentration [mg/L] 


\subsection{Biomass Characterization}

The SRB biomass produced in the reactor has been characterized in terms of its concentration and washout-out velocity.

\subsubsection{Volatile Suspended Solids}

It is assumed that the volatile suspended solids, VSS, indicated the biomass concentration present at a specific point in the reactor.

\subsubsection{Washout Velocity}

The upflow velocity in the reactor is given by:

$$
V_{\mathrm{o}}=\frac{\mathrm{Q}}{\mathrm{A}}
$$

Where,

$V_{o}=$ upflow velocity $[\mathrm{m} / \mathrm{h}]$

$\mathrm{Q}=$ volumetric flow rate $\left[\mathrm{m}^{3} / \mathrm{h}\right]$

$A=$ cross sectional area $\left[\mathrm{m}^{2}\right]$

It is assumed that whenever the upflow velocity, $V_{0}$, exceeded the settling velocity of the biomass, it was washed out of the reactor. On the other hand, whenever $V_{\circ}$ was less than 
the settling velocity of the biomass, it had gradually settled down. In case of the nonpacked bed, the biomass had settled near the bottom of the reactor, whereas, in case of the packed bed, the settling occurred on the media surface and near the bottom of the reactor. 


\section{CHAPTER 5. RESULTS}

\subsection{Phase I}

$2 \mathrm{~L}$ reactors were operated in batch mode for SRB growth. After the first 48 days of cultivating bacteria and controlling their growth, a sulfide concentration of $120-130 \mathrm{mg} / \mathrm{L}$ was reached. Although there were fluctuations in this concentration in the next 20 days, in general the steady state was observed.

The sulfide concentration was considered to be the main indicator of SRB activity in the three batch reactors. After obtaining the optimum sulfide concentration, a set of other three parallel reactors was inoculated with this culture. The dilution water used for substrate preparation was deionized water for Reactors I and II and tap water for Reactor III. Tap water is known to contain residual chlorine, and if it is not removed by means of boiling or overnight evaporation, it can affect the bacterial growth. This was observed during the first 10 days of Phase I, when the concentration of sulfide in Reactor III was lower than in the other two reactors. Consequently, the tap water was boiled for $10 \mathrm{~min}$, cooled overnight and then used for the preparation of new substrate. Each time a sample was withdrawn, it was replaced with a new substrate solution of equal volume.

Figure 5.1 shows the changes in sulfide concentration with time for the three $2 \mathrm{~L}$ reactors. The ORP and $\mathrm{pH}$ values over the same time are shown in Figures 5.2 and 5.3. 

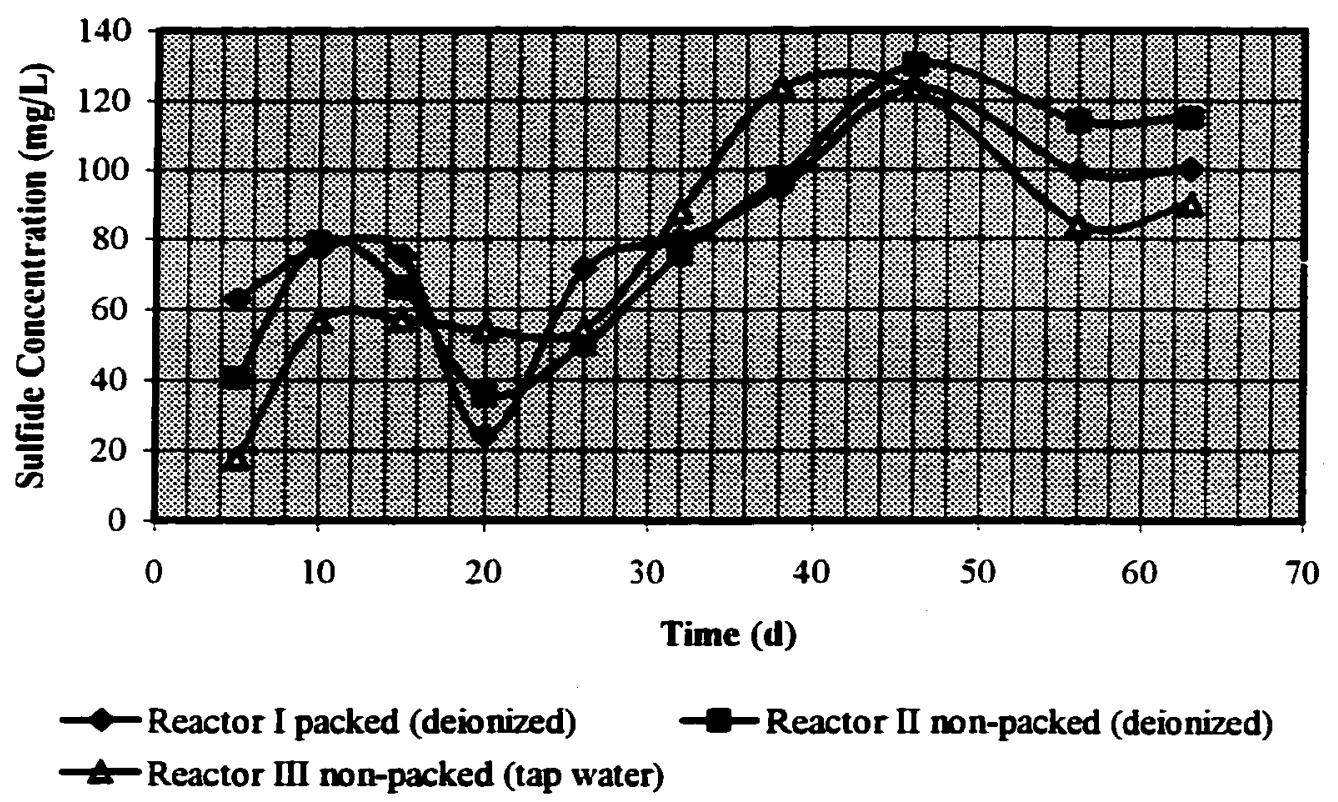

Figure 5.1 Sulfide Concentration vs Time (2 L Batch Reactors)

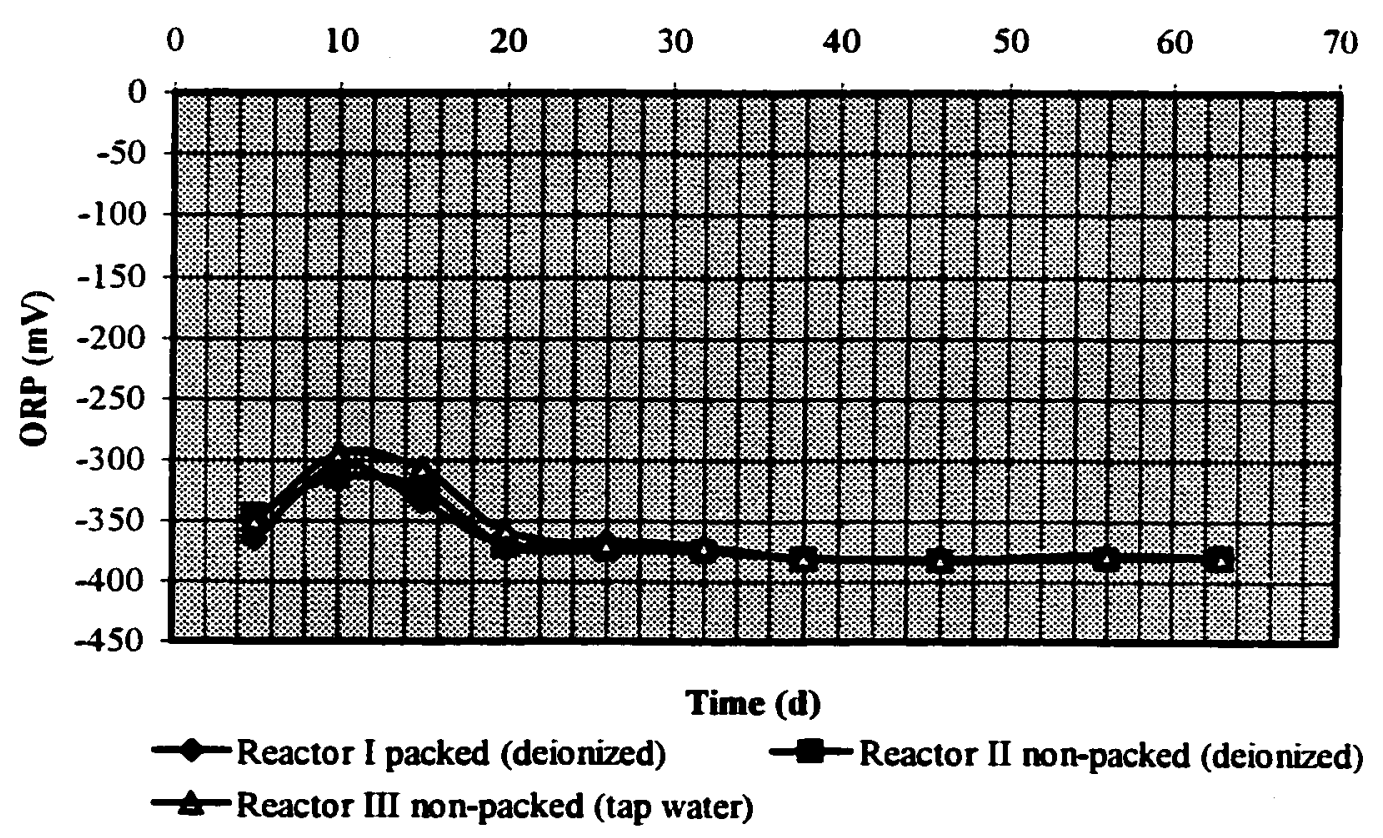

Figure 5.2 ORP vs Time (2 L Batch Reactors) 


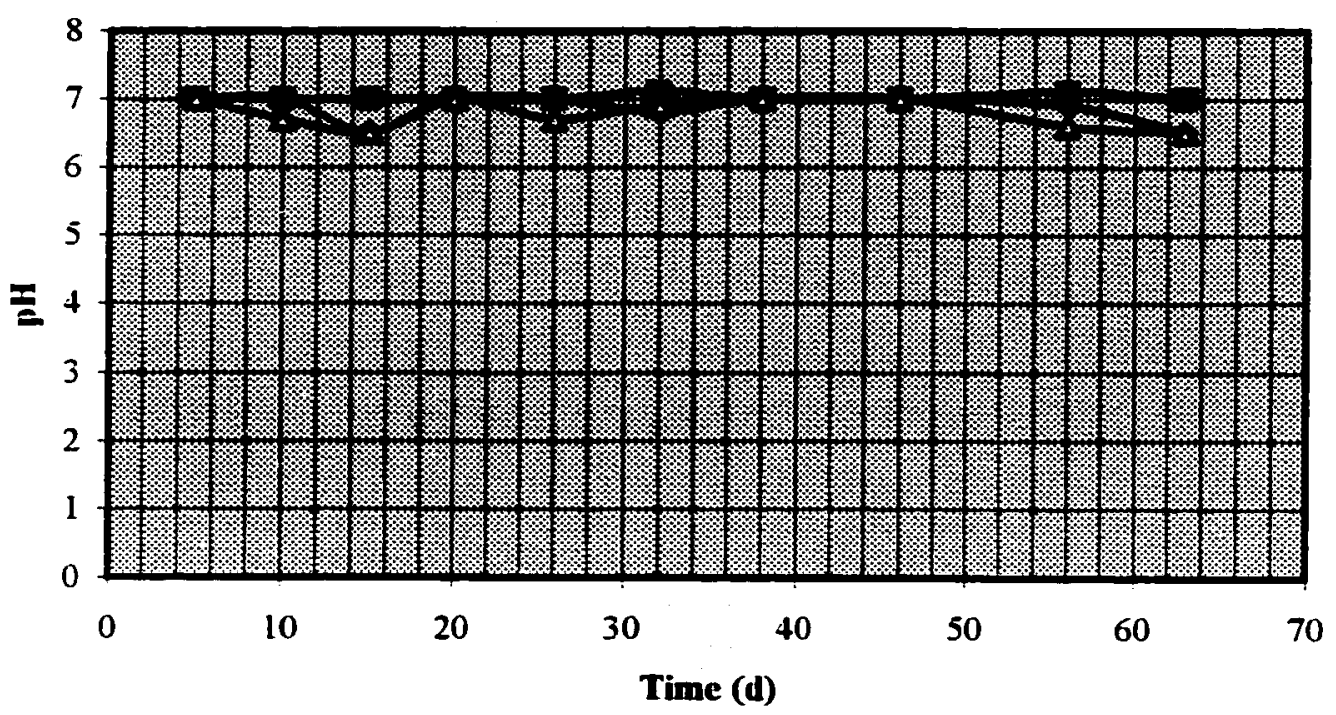

\footnotetext{
- Reactor I packed (deionized) $\quad-$ Reactor II non-packed (deionized)

$\rightarrow$ Reactor III non-packed (tap water)
}

Figure 5.3 pH vs Time (2 L Batch Reactors)

The sulfide concentrations are the average values between two measurements. No VSS analyses were done during Phase I. However, as reported in Section 3.1.2.2, the settled biomass from Reactor II, which was used as the seed for Phase II, had a VSS concentration of $4300 \mathrm{mg} / \mathrm{L}$ and SS concentration of $5700 \mathrm{mg} / \mathrm{L}$.

\subsection{Phase II}

The $10 \mathrm{~L}$ reactors in this phase were operated in a semi-continuous, draw-and-fill, manner and were fed with lactic acid as the sole carbon source. The main objective of this phase was to study the SRB growth under batch conditions and to determine the stoichiometry for the overall sulfates reduction. It was necessary to build up a healthy 
culture and high concentration of SRB in the reactors before starting the next phase of the study. The Phase II study was performed in the following sequences:

\section{$1^{\text {st }}$ Sequence and $2^{\text {nd }}$ Sequence}

As indicated in Chapter 3 , in the first sequence the reactors were inoculated with a healthy SRB culture, and fed with new substrate solution once every eight days, while in the second sequence the same procedure was followed once every four days. The change in sulfide concentration is shown in Figure 5.4.

During batch operation. the packed reactor presented an overall better performance. In case of the third reactor, its performance was fairly similar to the other non-packed reactor once the packing material was removed. Although the progressions of sulfide concentration for the packed and the non-packed reactors were slightly different, it can be observed that the final concentration reached was roughly the same. Therefore, no significant difference in the behavior of the three reactors was considered.

The ORP and $\mathrm{pH}$ values, Figures 5.5 and 5.6, remained within the optimum ranges of -300 and $-350 \mathrm{mV}$, and $6.5-7.0$, respectively.

$3^{\text {rd }}$ Sequence

In order to keep the bacteria active in the reactors, a weekly withdrawal-fill operation was done during the next 35 days and the sulfide concentration was monitored during that 
period. After that, analyses for sulfide, sulfate, VSS, ORP and pH were carried out for four consecutive days without refilling in between.

The sulfide progression for the $3^{\text {rd }}$ and $4^{\text {th }}$ sequences is presented in Figure 5.7. Similarly, VSS and pH results are plotted in Figures 5.8 and 5.9, respectively. It is evident that the sulfide concentration throughout that period remained fairly constant in each reactor. The highest sulfide concentration was found in Reactor I (packed bed), although its volatile suspended solids concentration was the lowest. This reflects that, in the packed reactor, the VSS remained low in the samples withdrawn because of the settling of solids on the packing material.

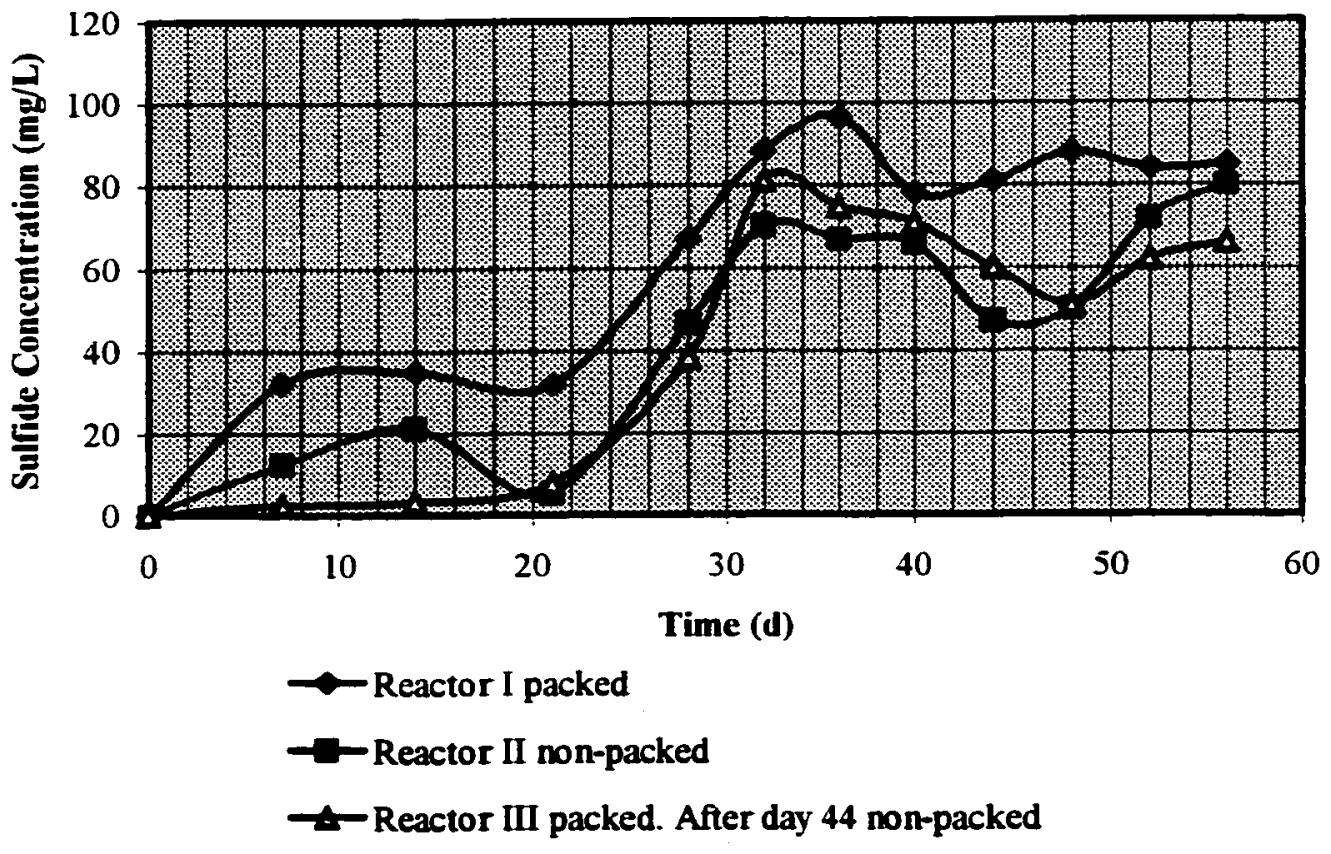

Figure 5.4 Sulfide Concentration vs Time $\left(10 \mathrm{~L}\right.$ Batch Reactors During $1^{\text {st }}$ and $2^{\text {nd }}$ Sequences) 


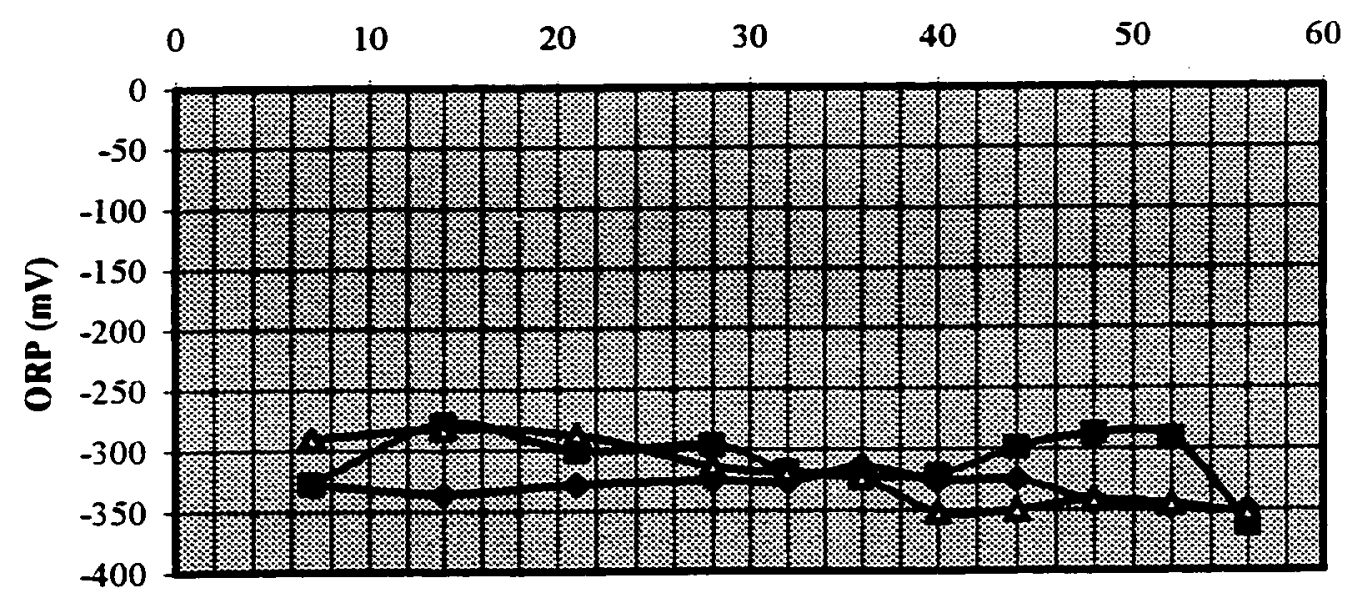

Time (d)

- Reactor I packed

- Reactor II non-packed

- Reactor III packed. After day 44 non-packed.

Figure 5.5 ORP vs Time (10 L Batch Reactors During $1^{\text {st }}$ and $2^{\text {nd }}$ Sequences)

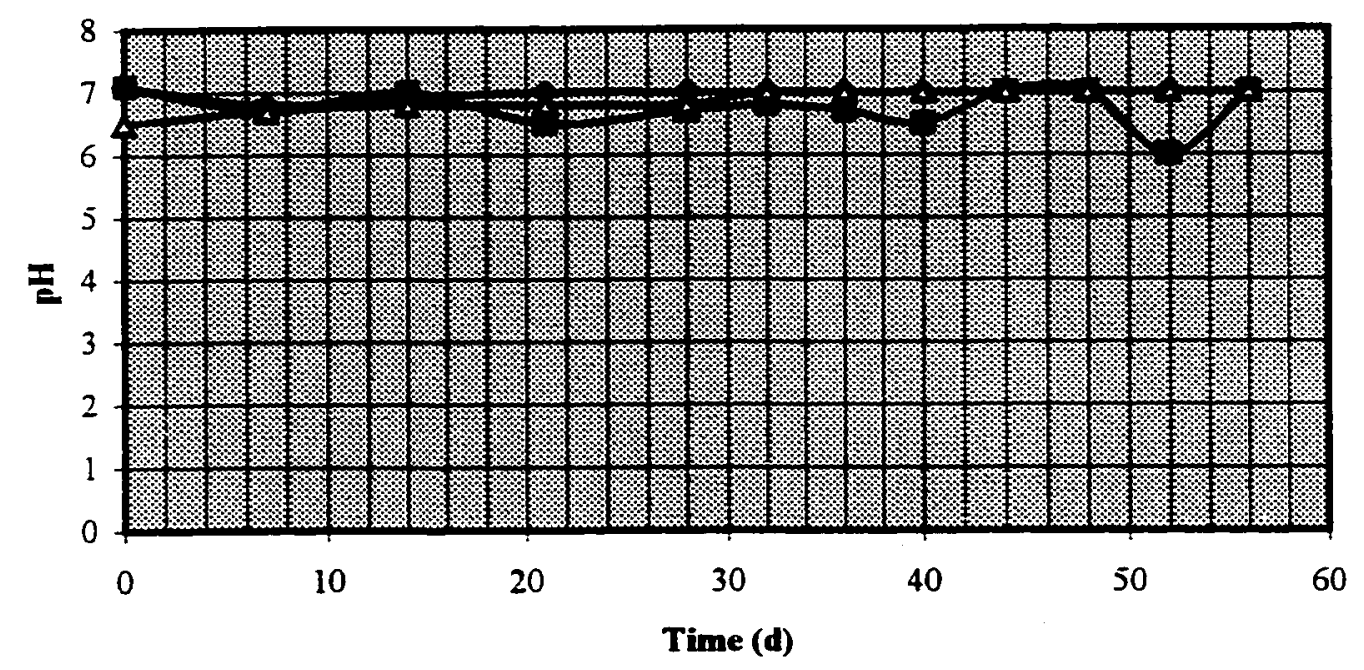

\footnotetext{
$\rightarrow$ Reactor I packed

-Reactor II non-packed

- Reactor III packed. After day 44 non-packed.
}

Figure 5.6 pH vs Time (10 L Batch Reactors During $1^{\text {st }}$ and $2^{\text {nd }}$ Sequences) 


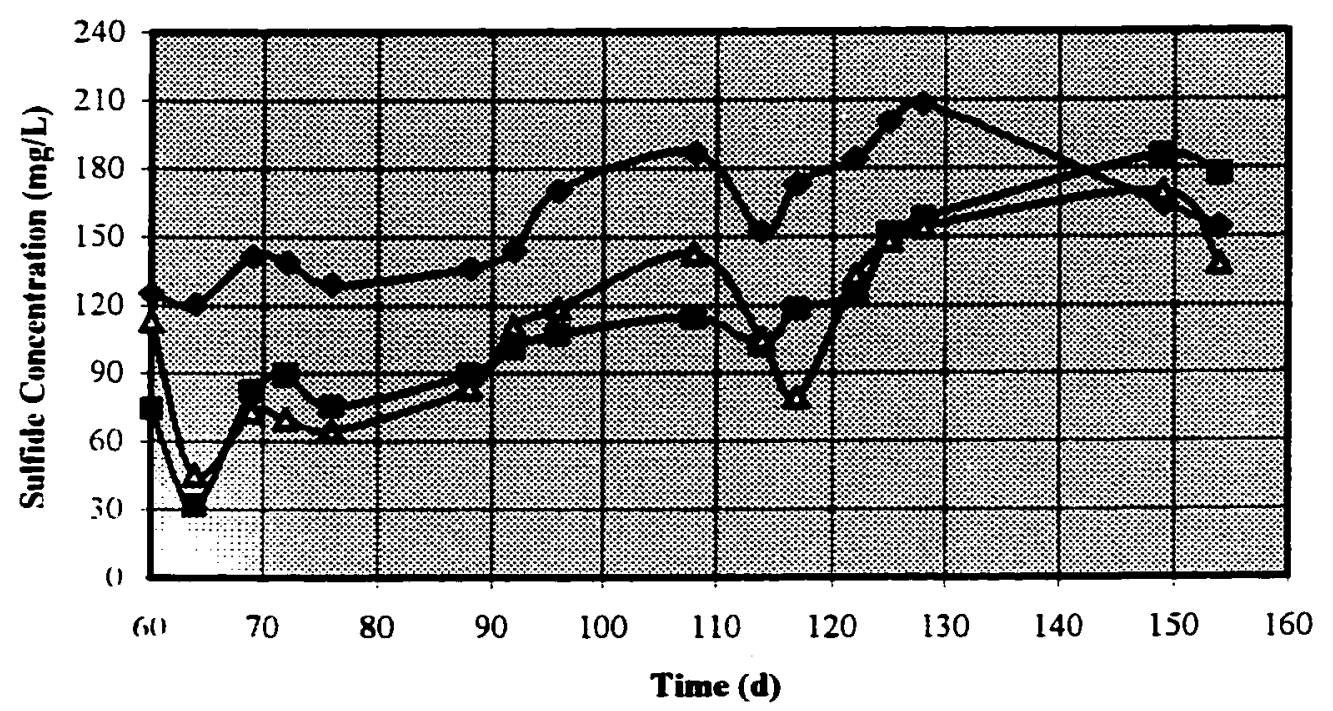

$\neg$ Kc:actor I packed $\rightarrow$ Reactor II non-packed $\rightarrow$ Reactor III non-packed

Figure 5.7 Sulfide Concentration vs Time $\left(10 \mathrm{~L}\right.$ Batch Reactors During $3^{\text {rd }}$ and $4^{\text {th }}$

\section{Sequences)}

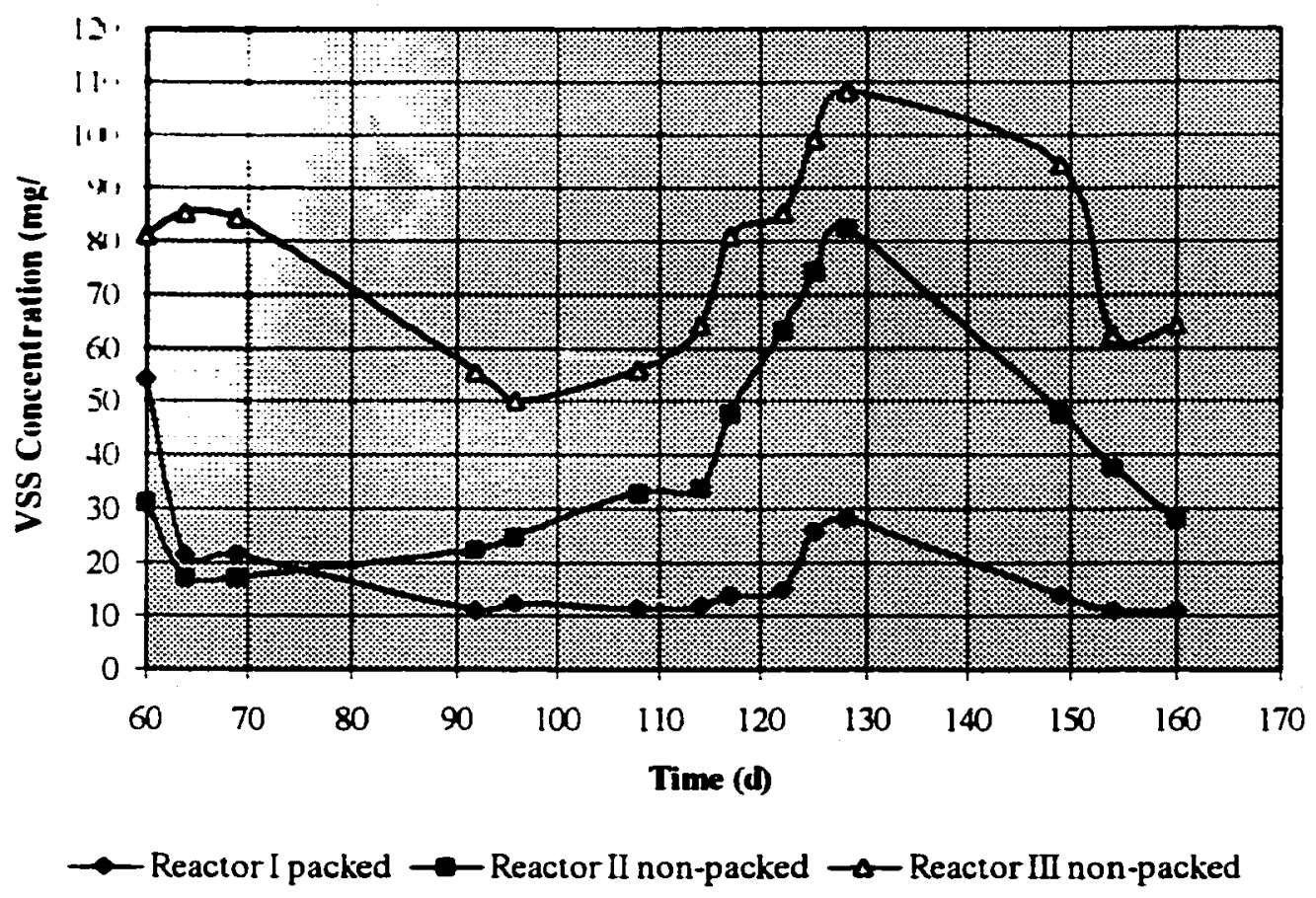

Figure 5.8 VSS Concentration vs Time (10 L Batch Reactors During $3^{\text {rd }}$ and $4^{\text {th }}$ Sequences) 


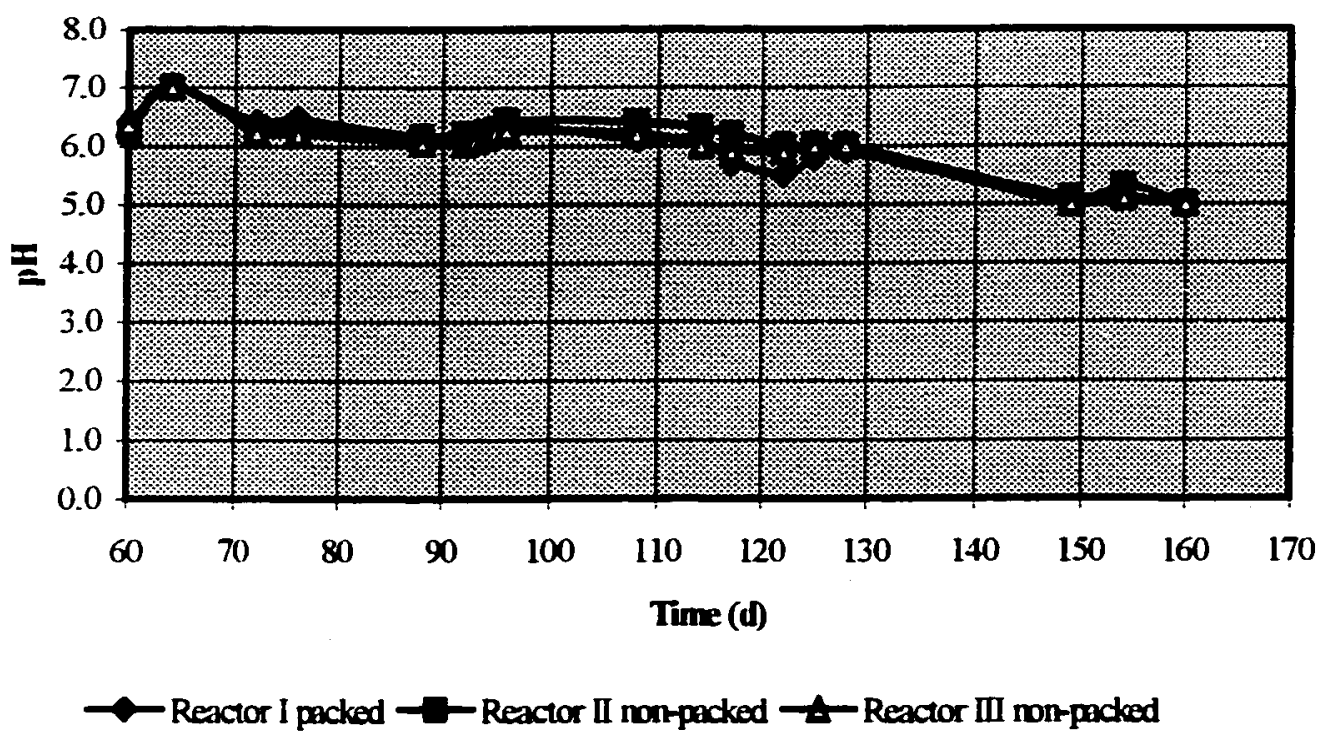

Figure 5.9 $\mathrm{pH}$ vs Time (10 L Batch Reactors During $3^{\text {rd }}$ and $4^{\text {th }}$ Sequences)

The sulfide, VSS. ORP and $\mathrm{pH}$ progressions over four consecutive days are presented in Figures 5.10. $511 . \leq 12$ and 5.13, respectively. No significant changes were observed. These observatıons on each reactor, without filling in between, gave a perspective of the fluctuations in sulfide and I'SS concentrations and the confidence in reproducing data.

\section{$4^{\text {th }}$ Sequence}

The fourth and last sequence of batch operation was carried out with a new substrate formulation to establish the relationship between sulfide production and VSS concentration The three reactors were used and the consecutive analyses were done at 3 to 5 days interial in order to define the sulfide and VSS relationship and the trends along the reactors' height Each reactor was provided with sampling ports equally spaced at 


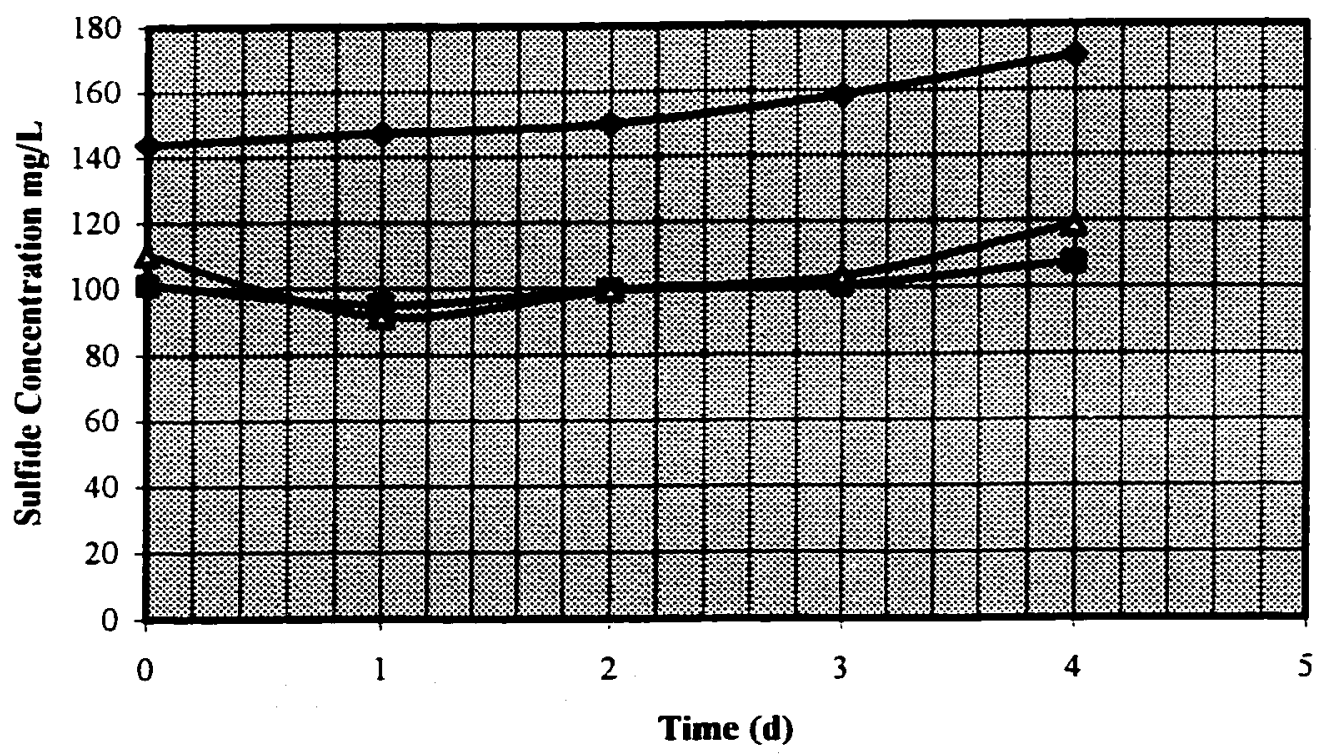

$\multimap$ Reactor I packed $\rightarrow-$ Reactor II non-packed $\rightarrow$ Reactor III non-packed

Figure 5.10 Sulfide Concentration vs Time (10 L Batch Reactors Consecutive)

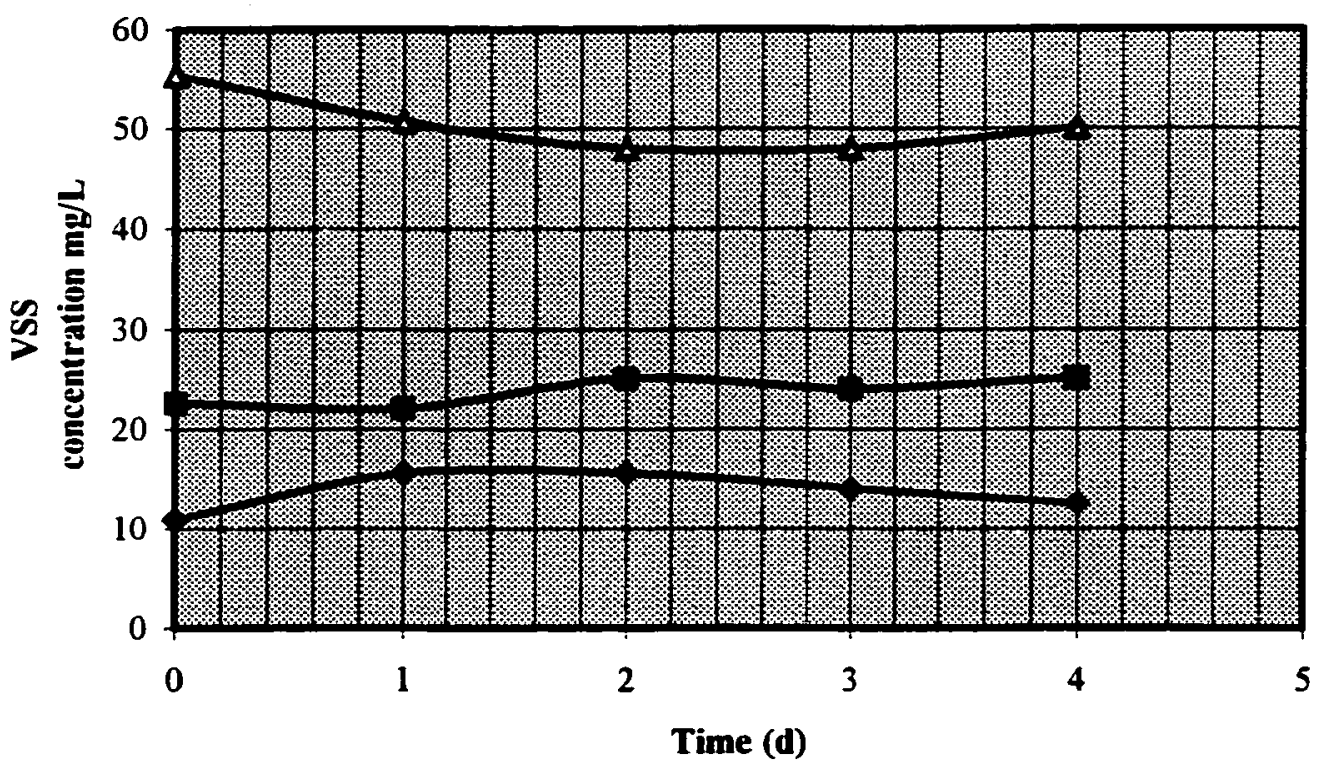

$\longrightarrow$ Reactor I packed $\rightarrow$ Reactor II non-packed $\rightarrow$ Reactor III non-packed

Figure 5.11 VSS Concentration vs Time (10 L Batch Reactors Consecutive) 


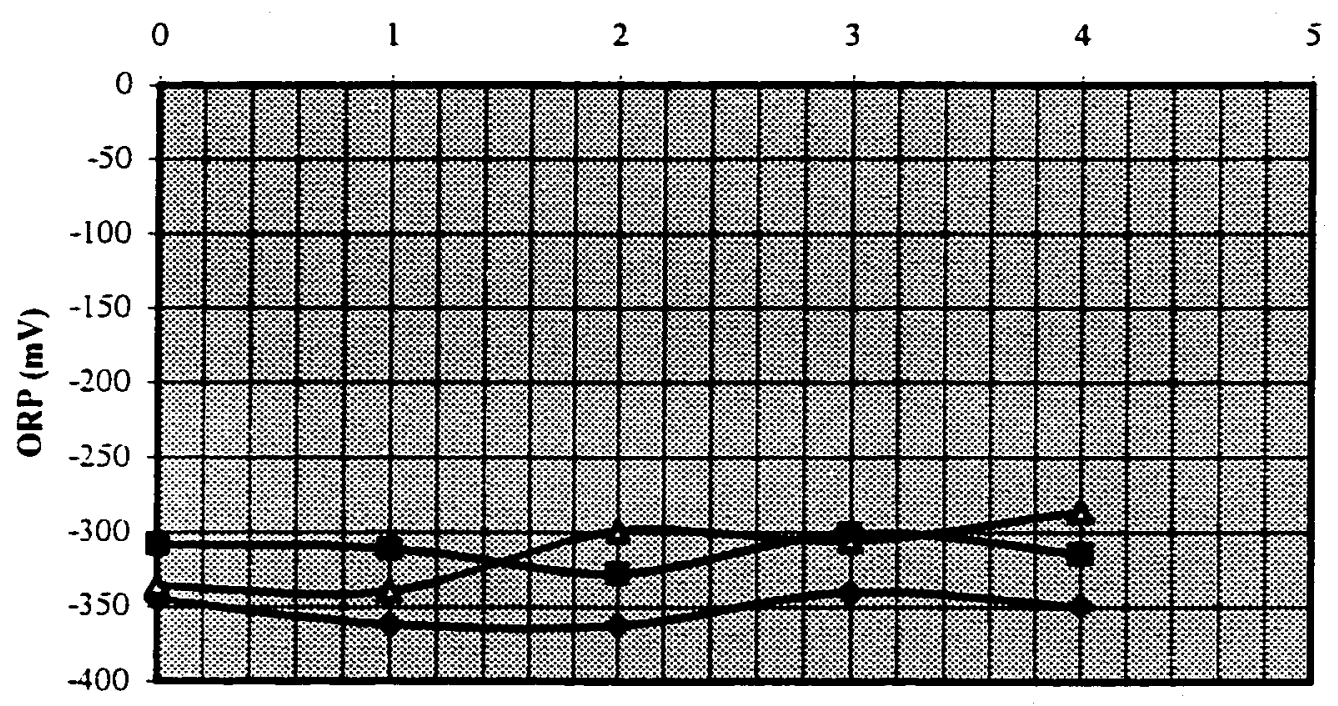

Time (d)

$\rightarrow$ Reactor I packed $\rightarrow-$ Reactor II non-packed $\rightarrow$ Reactor III non-packed

Figure 5.12 ORP vs Time (10 L Batch Reactors Consecutive)

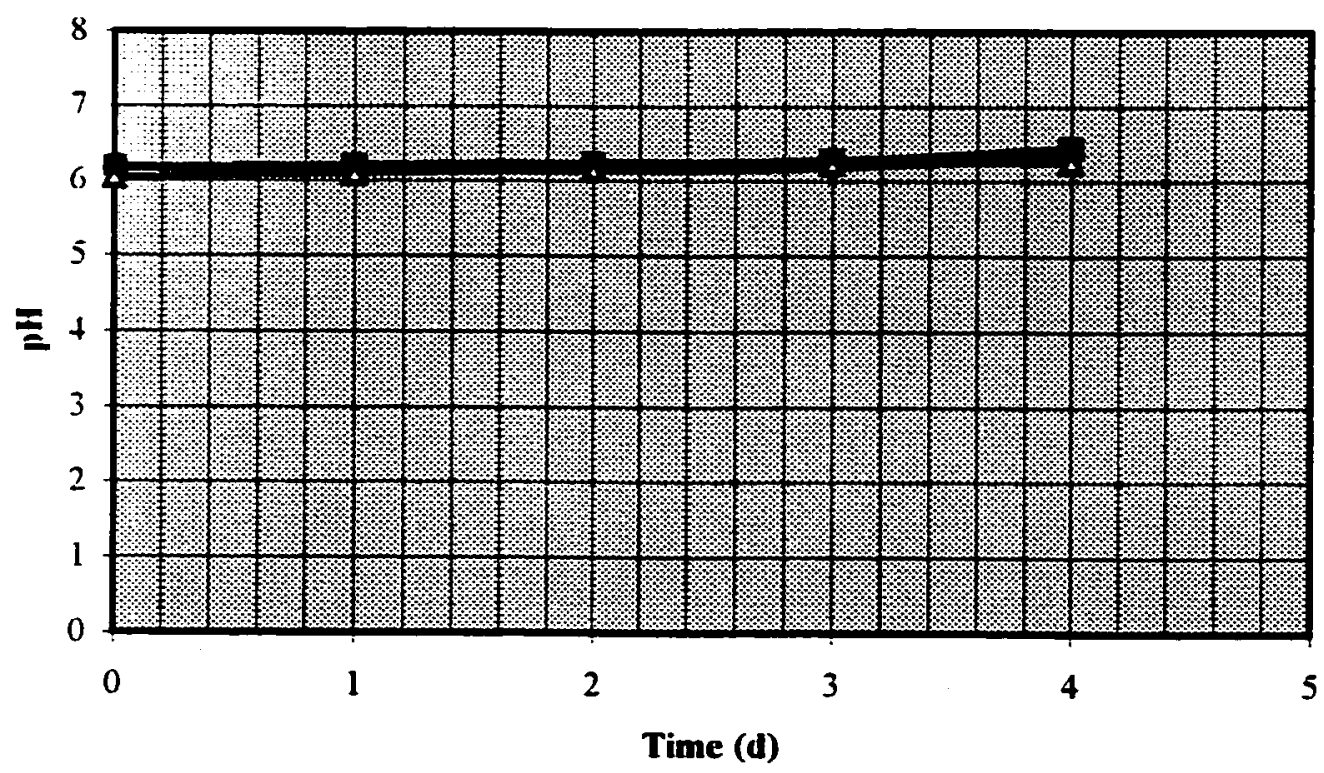

$\sim$ Reactor I packed $\rightarrow$ Reactor II non-packed $\rightarrow$ Reactor III non-packed

Figure 5.13 pH vs Time (10 L Batch Reactors Consecutive) 
$300,600,900$ and $1200 \mathrm{~mm}$ from the bottom of the reactor. The samples for these consecutive analyses were collected from the first $(300 \mathrm{~mm})$, second $(600 \mathrm{~mm})$ and third $(900 \mathrm{~mm})$ ports. The results and mass balance calculations are shown in Table 5.1.

In the mass balance calculations, the influence of the activity of the biomass settled at the bottom of the reactors was neglected since both sulfide and VSS concentrations in suspension at different ports were considered. This assumption was justified based on a separate study in which it was observed that the settling velocity of biomass in a batch SRB culture was very low and, therefore, most of the biomass produced in suspension remained in suspension during 3-5 day period used in the mass balance calculations.

The VSS and sulfide concentrations are the average values between two measurements. The sulfide concentrations were determined after the pretreatment of samples with zinc acetate solution in order to concentrate the sulfide and remove organic substances that could cause interterences It was found that these sulfide concentration values were 85$90 \%$ of the values ohtaned without pretreatment. Since for each analysis, $0.5 \mathrm{~L}$ of sample was withdrawn per pon ( $5 \mathrm{~L}$ total) and this resulted in wasting a certain amount of sulfide, the sulfide mass halance was based in the following equation:

$$
\text { Mass of Sultide Produced }=\sum V_{1} S_{\text {linal }}-\left[\left(\sum_{n=1}^{3}\left(V_{i}-0.5\right)^{*} S_{\text {initial }}\right)+1.5 S_{\text {teed }}\right]
$$

Where,

$V_{i}=$ initial reactor volume [L] 
$S_{\text {initial }}=$ initial sulfide concentration $[\mathrm{mg} / \mathrm{L}]$

$S_{\text {tinal }}=$ final sulfide concentration $[\mathrm{mg} / \mathrm{L}]$

$S_{\text {feed }}=$ feed sulfide concentration $=0$ (assumed).$[\mathrm{mg} / \mathrm{L}]$

The same approach was taken for the VSS mass balance and the following equation was used:

$$
\text { Mass of Sulfide Produced }=\sum V_{i} V_{S S} \text { final }-\left[\left(\sum_{n=l}^{3}\left(V_{i}-0.5\right)^{*} V_{S S_{\text {initial }}}\right)+1.5 \text { VSS }_{\text {feed }}\right]
$$

Where,

$\mathrm{VSS}_{\text {initial }}=$ initial VSS concentration $[\mathrm{mg} / \mathrm{L}]$

$\mathrm{VSS}_{\text {final }}=$ final VSS concentration $\{\mathrm{mg} / \mathrm{L}]$

$\mathrm{VSS}_{\mathrm{feed}}=$ feed VSS concentration $=0$ (assumed). $[\mathrm{mg} / \mathrm{L}]$

The mass balance analysis and the average corresponding values for VSS and sulfide concentrations are shown in Table 5.1 and Figures 5.14, 5.15 and 5.16 for the three reactors. These average values and stoichiometric Equations 4.1 to 4.5 were then used for mass and electron balance calculations in order to determine the proportion in which the sulfate reduction and biosynthesis were taking place. Tables 5.2, 5.3 and 5.4 show mass and electron balances for VSS growth and sulfide production. From these calculations, it is found that about $70 \%$ of the organic matter (lactate) was bio-oxidized and $30 \%$ was bio-synthesized for Reactors II and III, both non-packed. Since samples collected from Reactor I (packed) for VSS did not include settled solids, these calculations were not considered to be representative. 


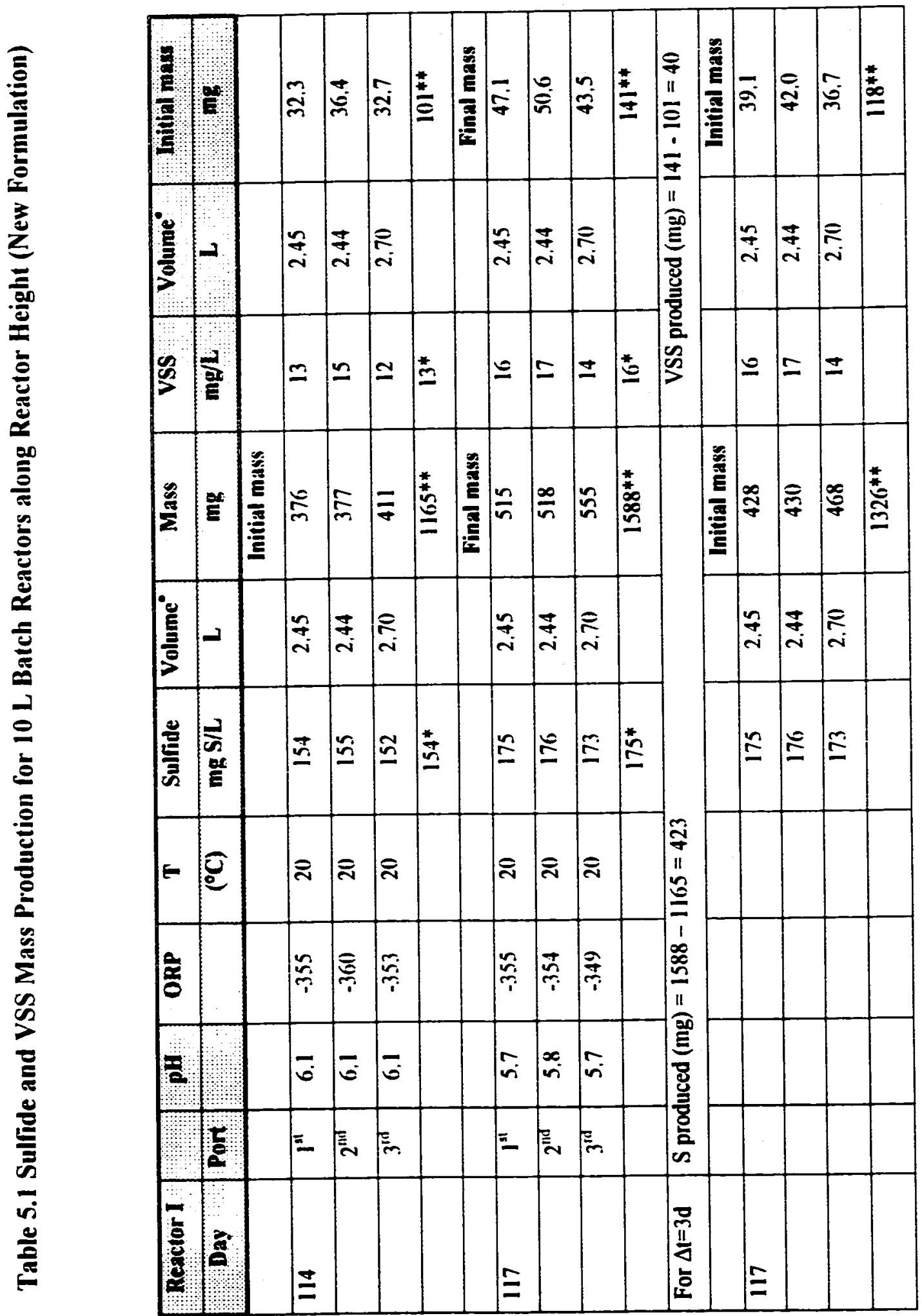




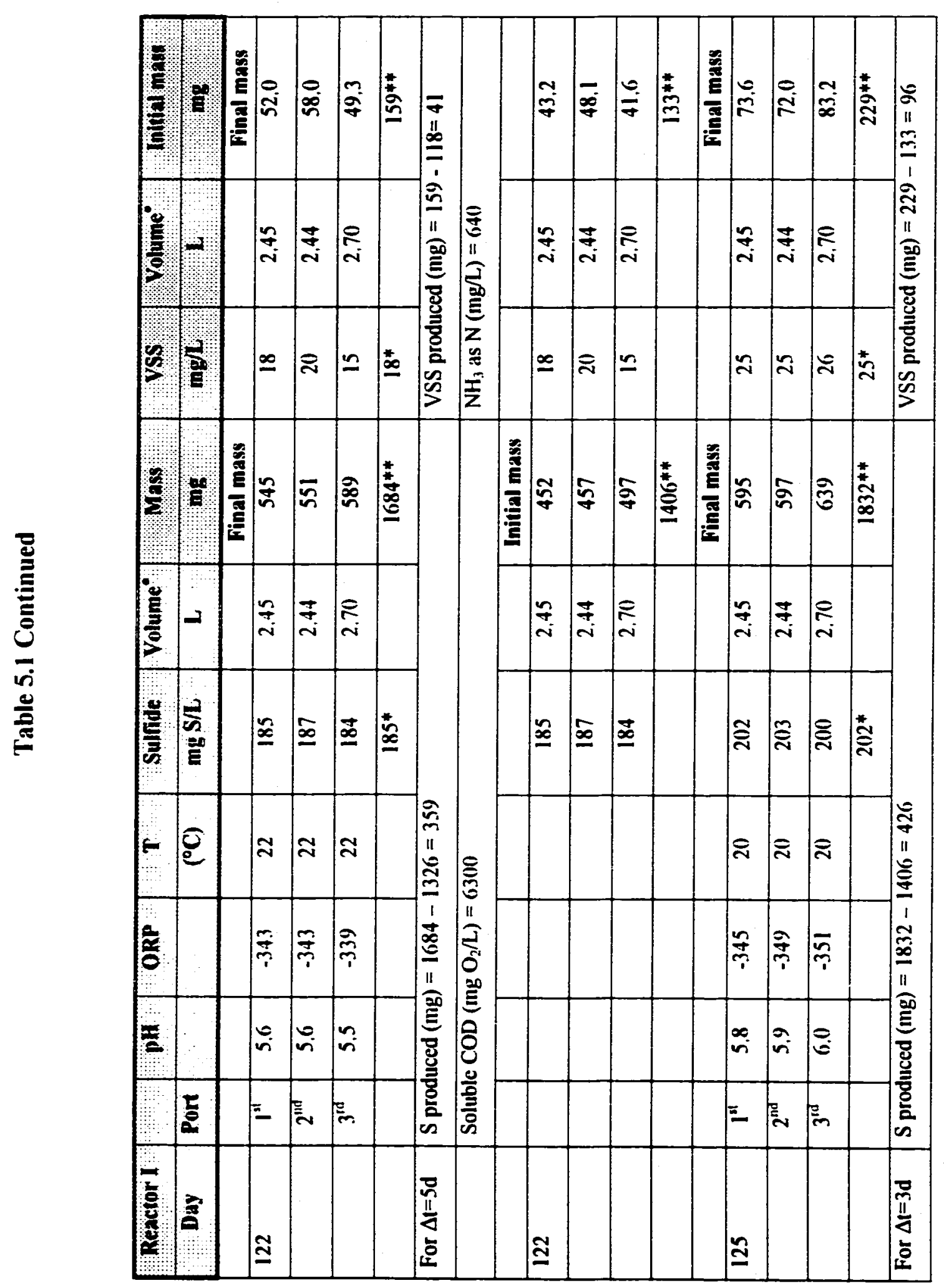




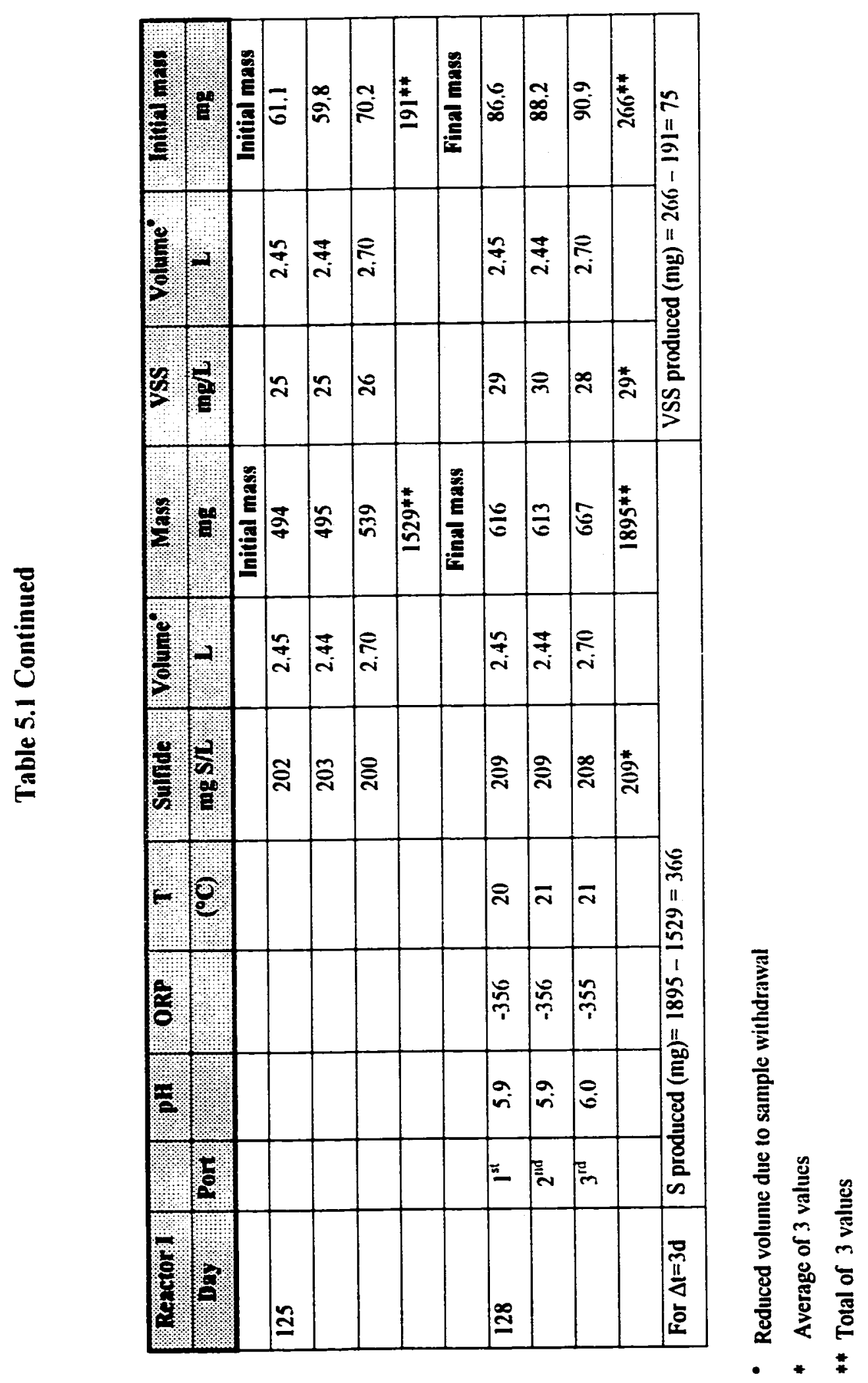




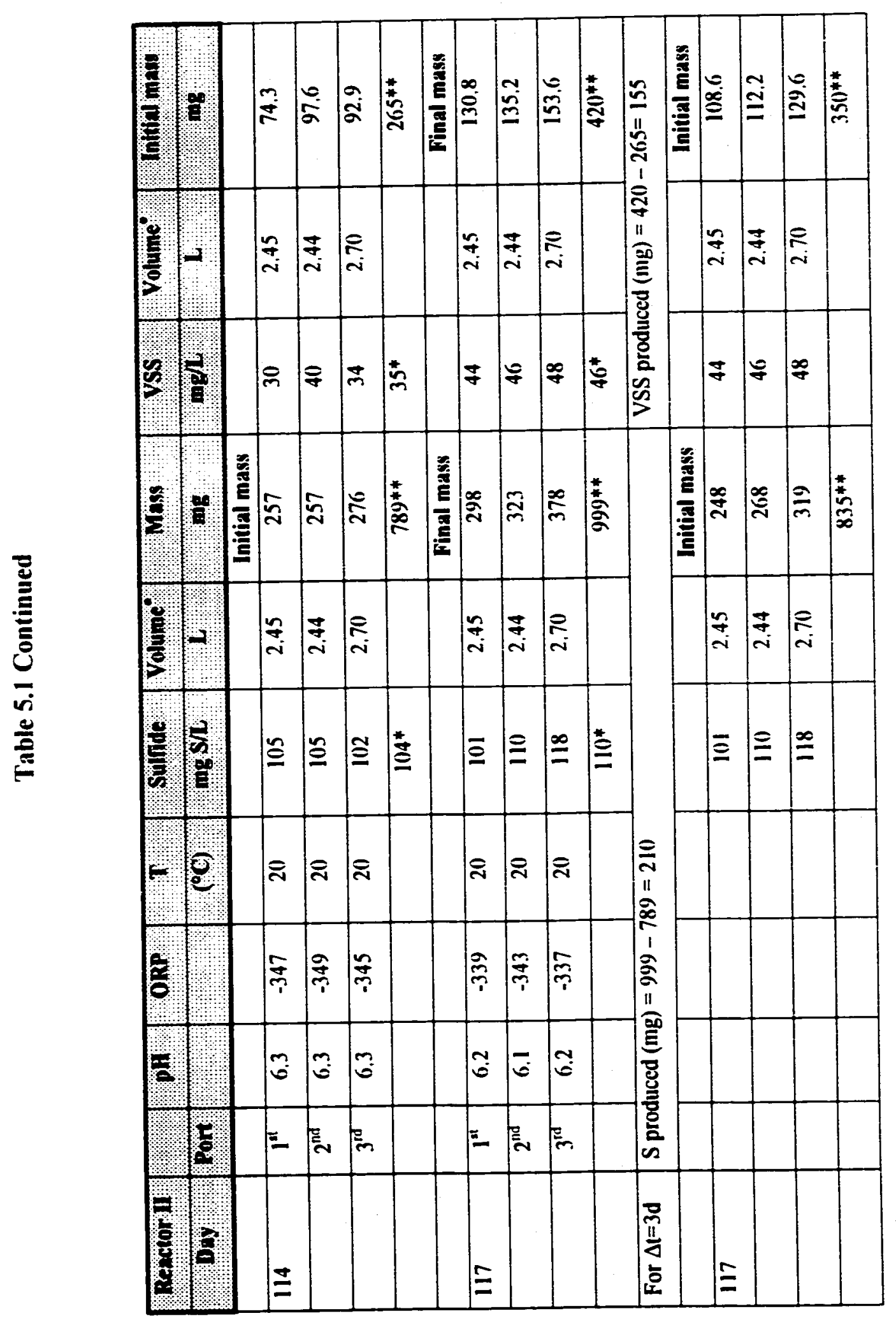




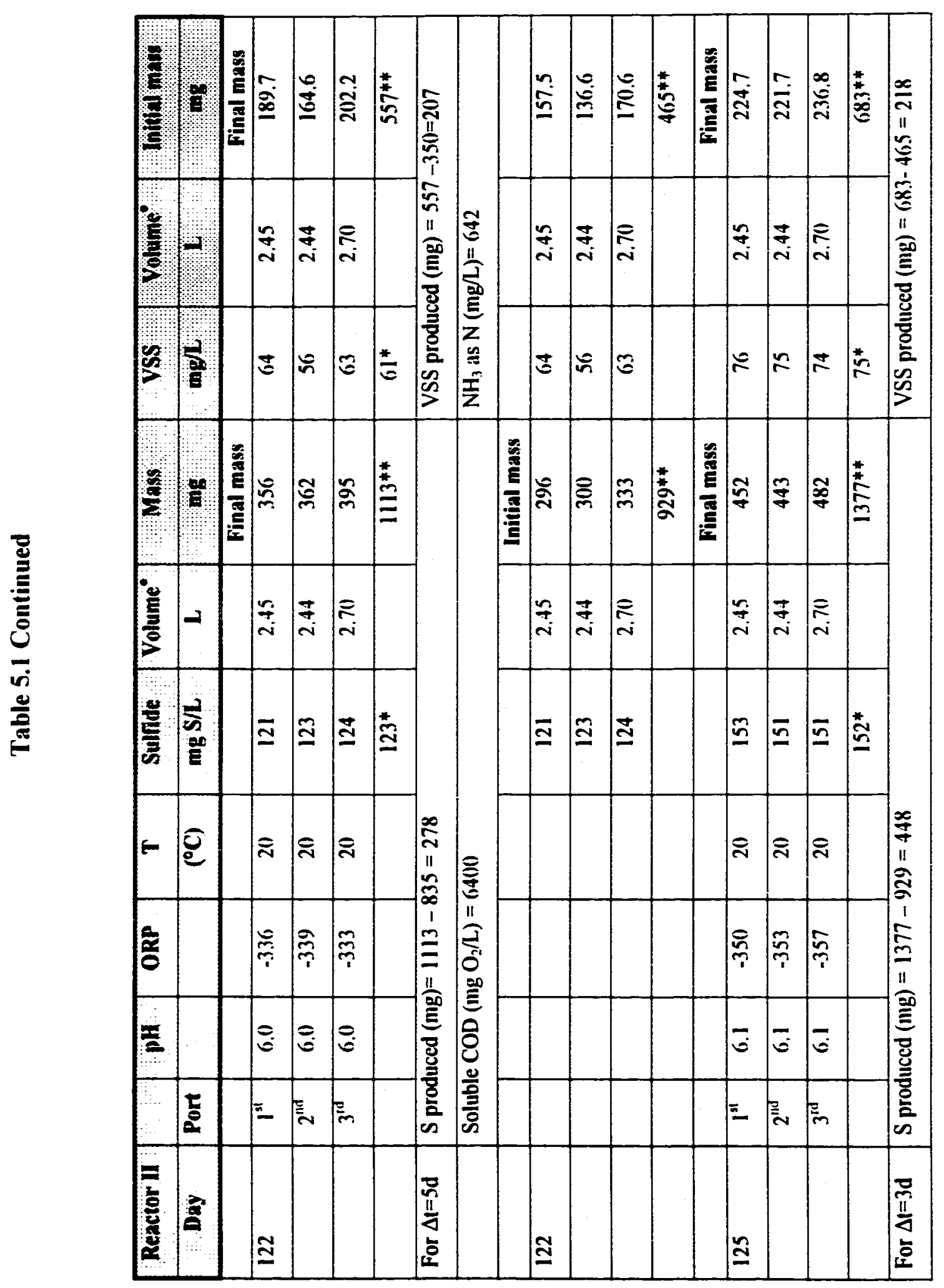




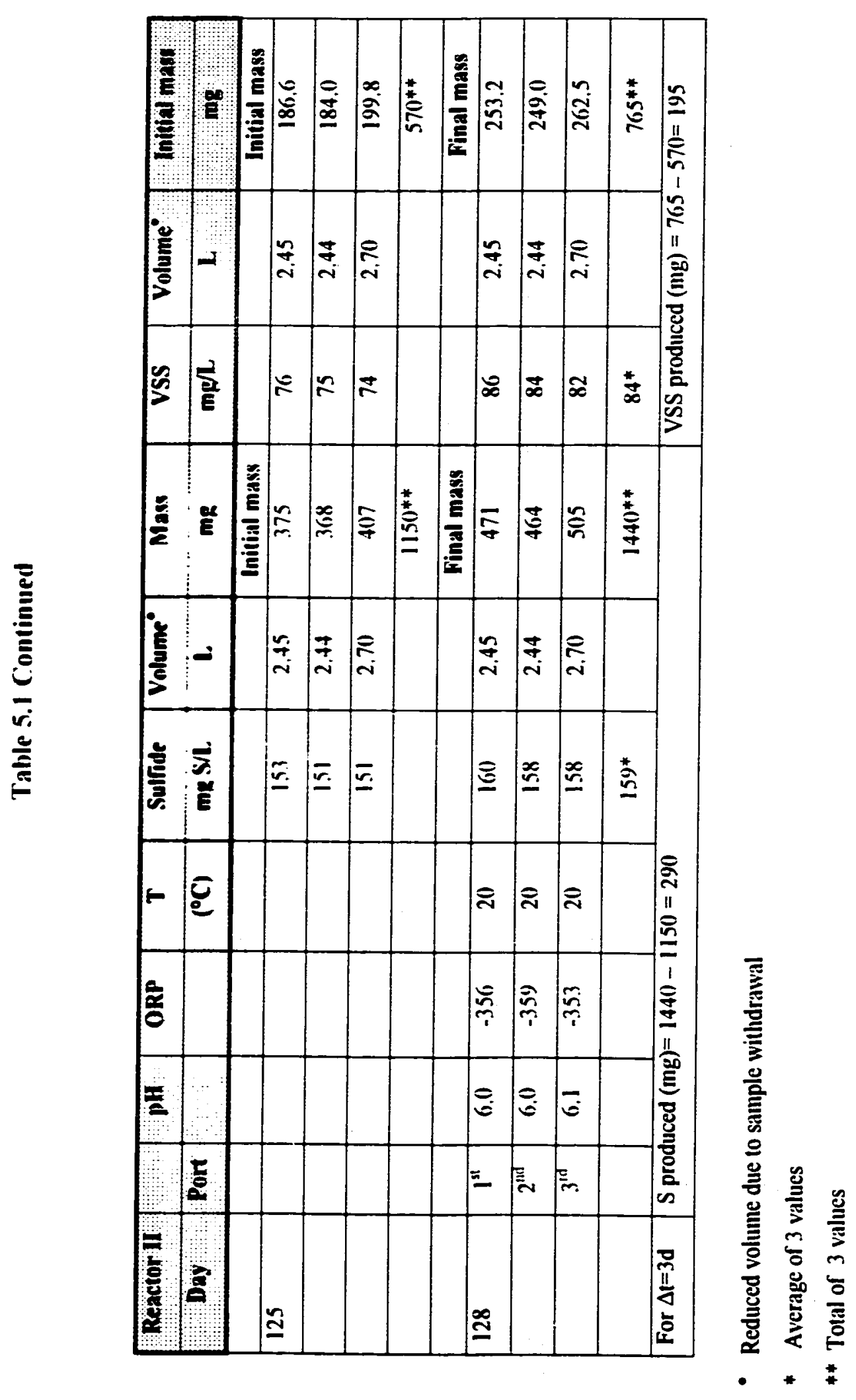




\begin{tabular}{|c|c|c|c|c|c|c|c|c|c|c|c|c|c|c|c|c|c|}
\hline 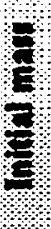 & Ee & & $\bar{\theta}$ & તิ & $\underline{n}$ & 意 & 爰 & 赵 & $\underset{\sim}{\sim}$ & 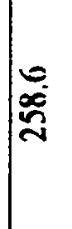 & 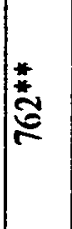 & \multirow{3}{*}{ 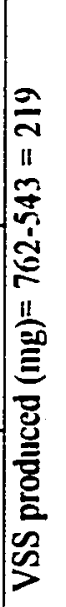 } & 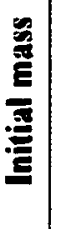 & $\tilde{\tilde{a}}$ & $\cong$ & $\frac{\tilde{x}}{\tilde{x}}$ & 荧 \\
\hline$\frac{8}{8}$ & 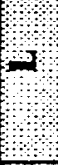 & & $\stackrel{\sim}{a}$ & $\underset{\Delta}{\pi}$ & $\underset{\sim}{i}$ & & & $\stackrel{\sim}{i}$ & $\underset{\sim}{\pi}$ & $\underset{\sim}{\stackrel{a}{N}}$ & & & & $\stackrel{\sim}{\vec{i}}$ & $\underset{\sim}{ \pm}$ & $\underset{\nabla i}{i}$ & \\
\hline 8 & 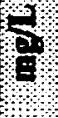 & & $E$ & $\bar{\sigma}$ & $\mathbb{E}$ & $\stackrel{*}{\star}$ & & $\bar{\sigma}$ & $\ddot{\infty}$ & $\bar{\infty}$ & $\frac{*}{\infty}$ & & & $\bar{a}$ & $\bar{\infty}$ & $\bar{x}$ & \\
\hline$\frac{2}{4}$ & 8 & 产 & $\overline{\tilde{E}}$ & $\bar{\approx}$ & $\tilde{\approx}$ & $\begin{array}{l}\text { 謈 } \\
⿱ 亠 乂\end{array}$ & 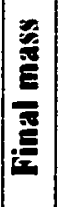 & $\approx$ & 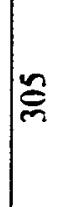 & $\tilde{\sim}$ & $\frac{*}{a}$ & & 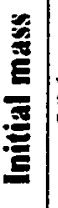 & సે & $\tilde{\approx}$ & $\frac{ \pm}{\sim}$ & 莣 \\
\hline$\frac{3}{3}$ & 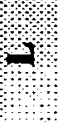 & & $\stackrel{\sim}{i}$ & $\underset{Z}{*}$ & $\stackrel{F}{\stackrel{r}{*}}$ & & & $\stackrel{n}{i}$ & $\underset{\sim}{\vec{i}}$ & $\stackrel{R}{i}$ & & & & $\stackrel{\sim}{i}$ & $\underset{\sim}{\vec{j}}$ & $\underset{\sim}{\stackrel{F}{i}}$ & \\
\hline 8 & $\frac{7}{8}$ & & 气 & $\cong$ & $\stackrel{\varrho}{\varrho}$ & $\stackrel{\text { }}{\varrho}$ & & $\bar{\Xi}$ & $\vec{\Xi}$ & $\approx$ & 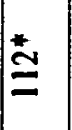 & & & $\bar{\beth}$ & I્ & $\approx$ & \\
\hline$\theta$ & 8 & & $\bar{\sim}$ & $\bar{\sim}$ & $\bar{\sim}$ & & & $\bar{\approx}$ & $\equiv$ & $\equiv$ & & $\cong$ & & & & & \\
\hline$\frac{8}{8}$ & 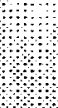 & & $\stackrel{\infty}{\grave{r}}$ & $\bar{n}$ & $\stackrel{2}{7}$ & & & $\frac{\pi}{7}$ & $\underset{7}{\tilde{7}}$ & సิ & & $\frac{1}{2}$ & & & & & \\
\hline 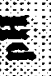 & 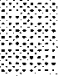 & & $\hat{\sigma}$ & 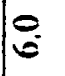 & $\stackrel{8}{0}$ & & & a & $\hat{\sim}$ & in & & 灵 & & & & & \\
\hline 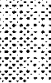 & 5 & & $\Xi$ & E & $E_{m}$ & & & $\equiv$ & స & $e_{m}$ & & 亮 & & & & & \\
\hline$\frac{3}{8} \frac{3}{8}$ & 8 & & $\Xi$ & & & & & $\Xi$ & & & & 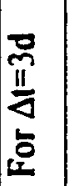 & & $\leqq$ & & & \\
\hline
\end{tabular}




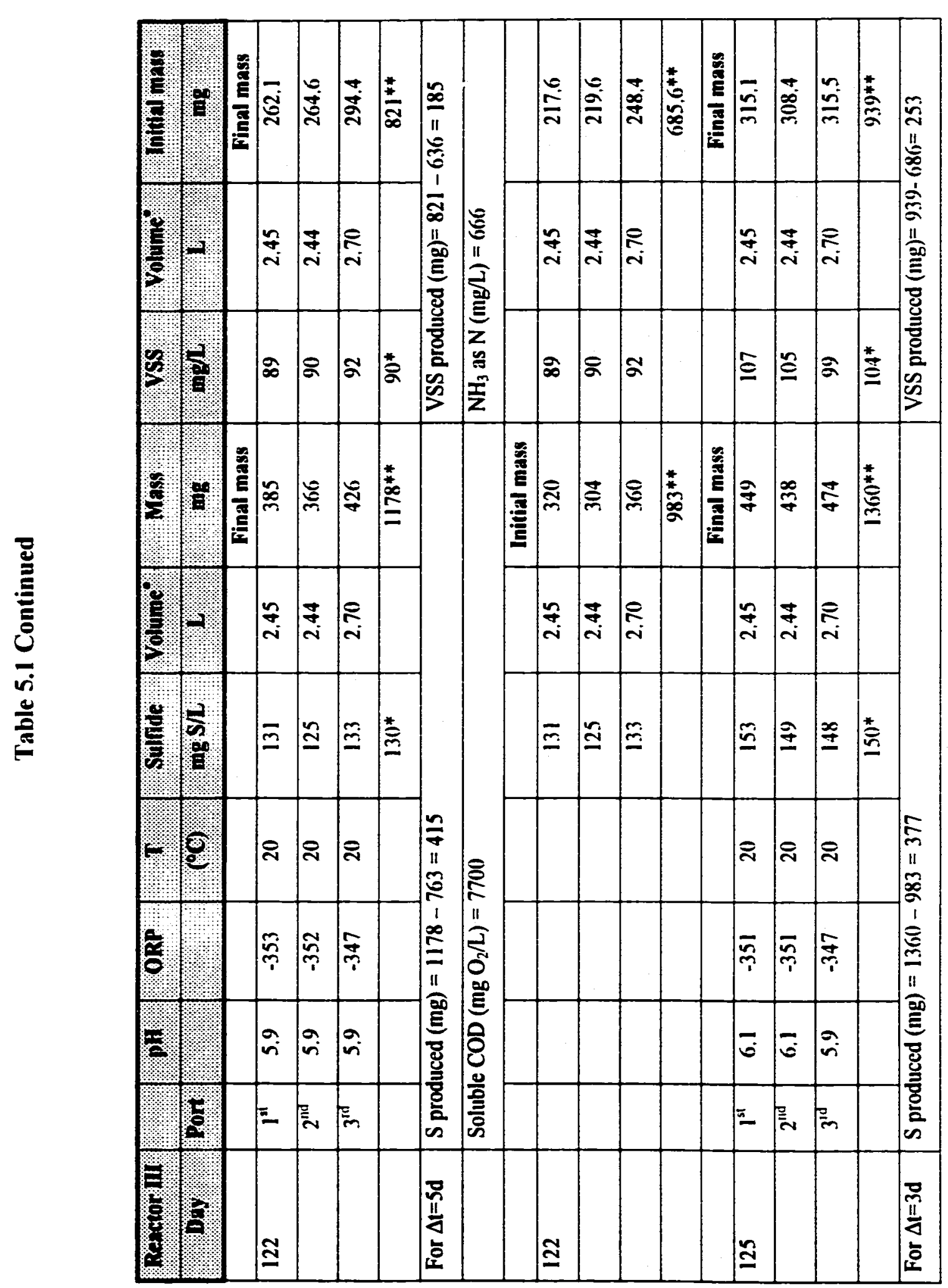




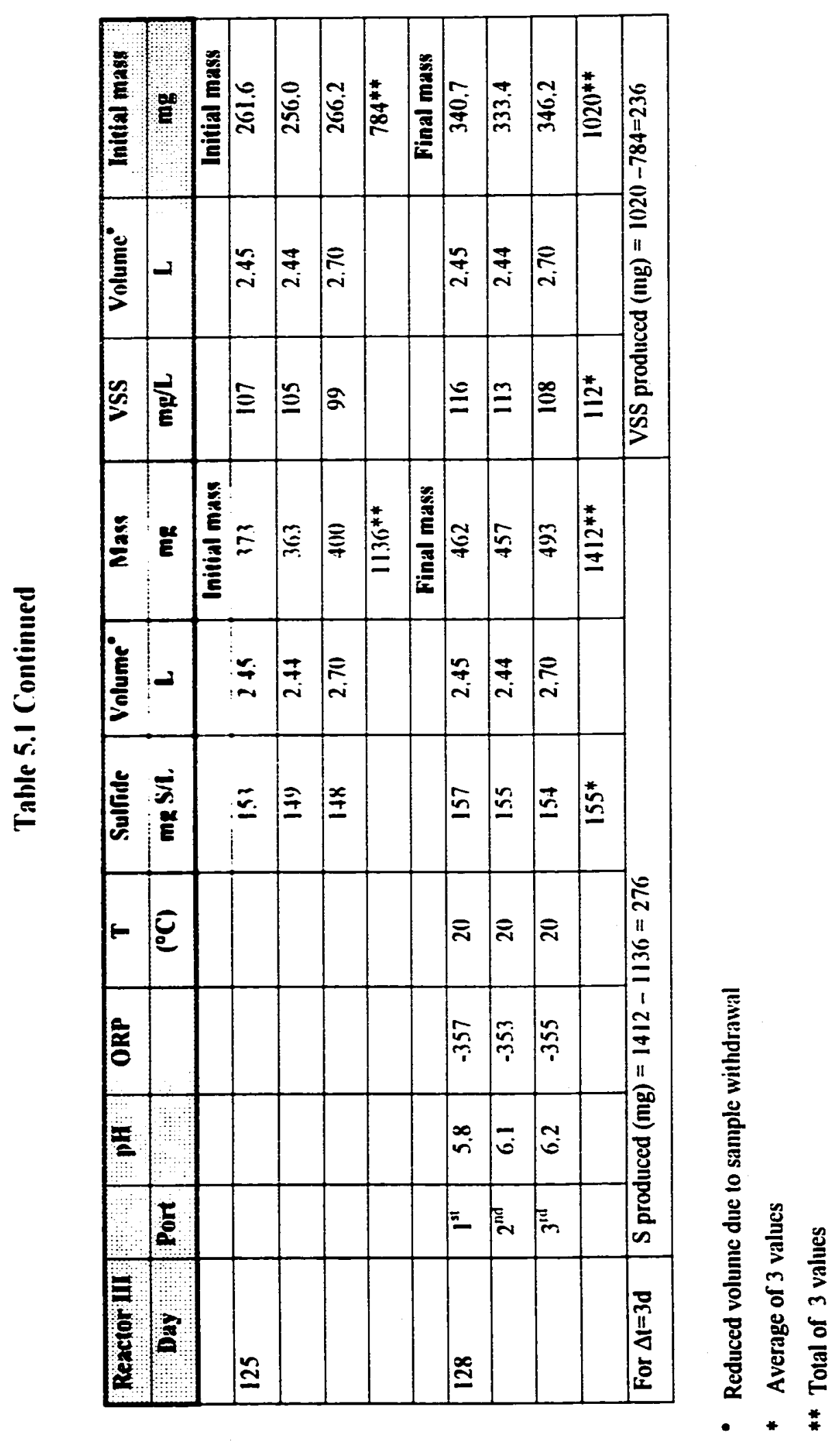




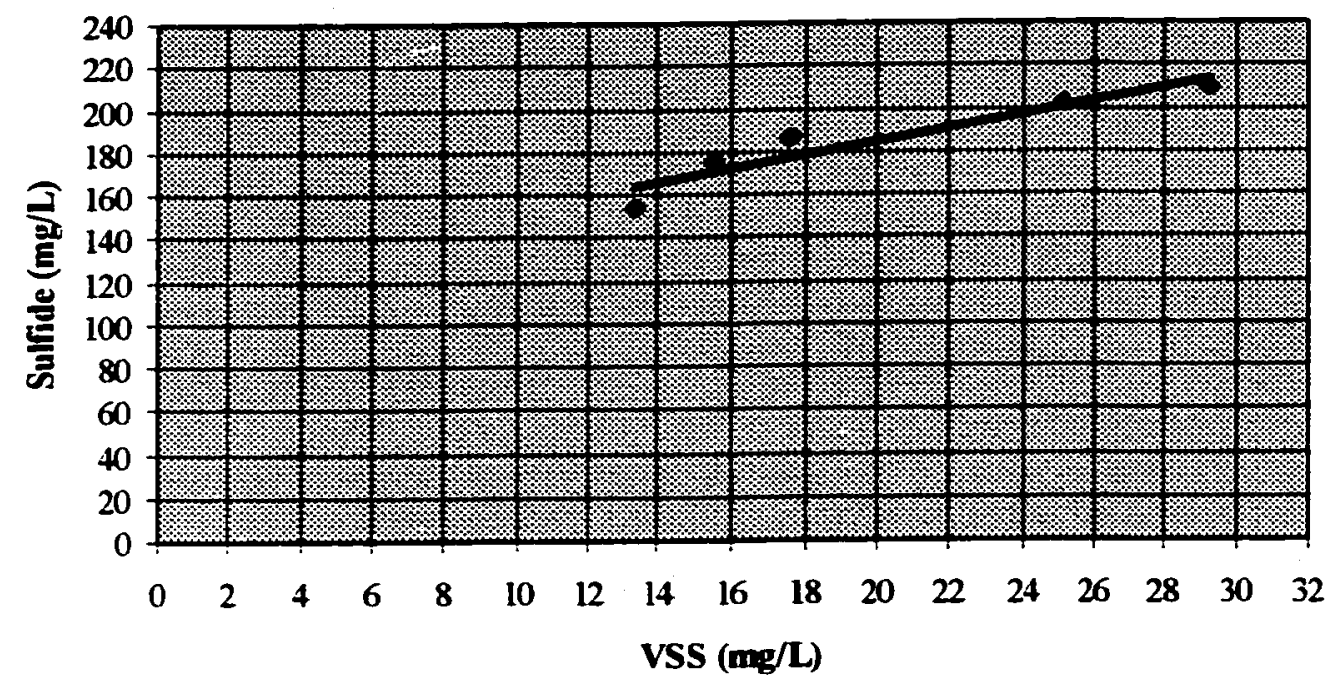

Figure 5.14 Sulfide vs VSS Concentrations for Reactor I (packed). $4^{\text {th }}$ Sequence

Sulfide $=3.07$ VSS $+123 \quad R^{2}=\mathbf{0 . 8 8 8}$

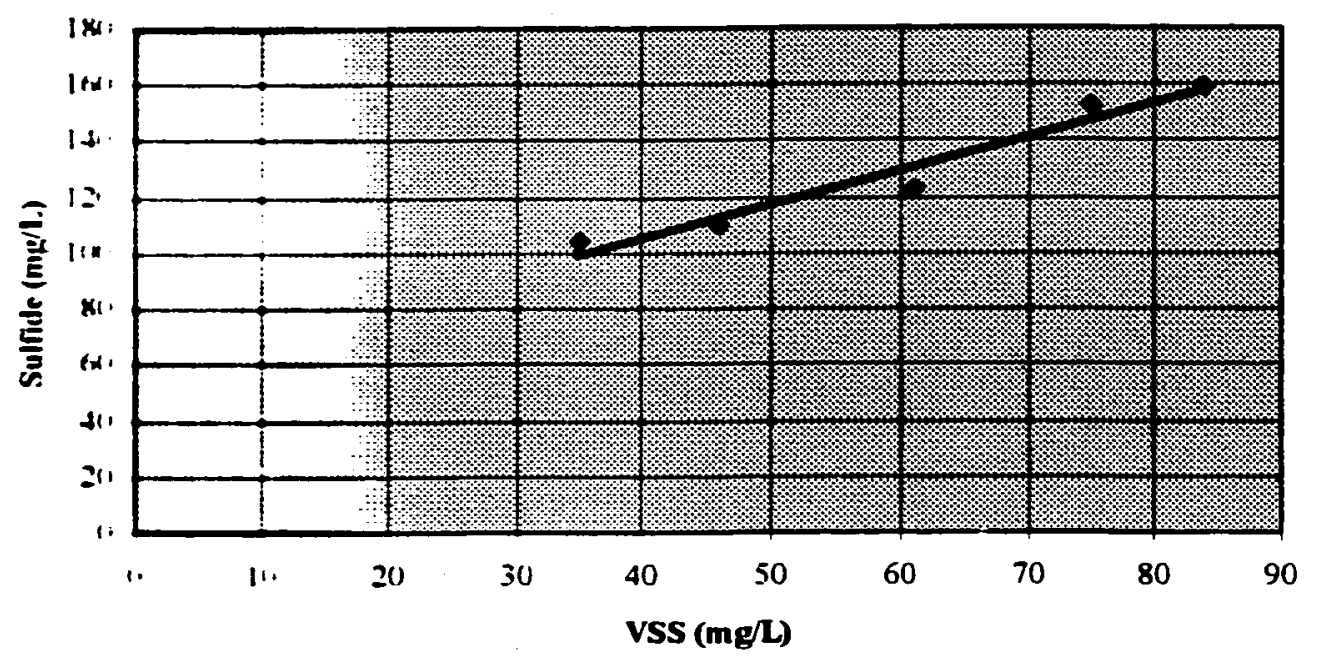

Figure 5.15 Sulfide is ISS Concentrations for Reactor II (non-packed). $4^{\text {th }}$ Sequence Sulfide $=1.20$ VSS $+57.3 \quad R^{2}=0.956$ 


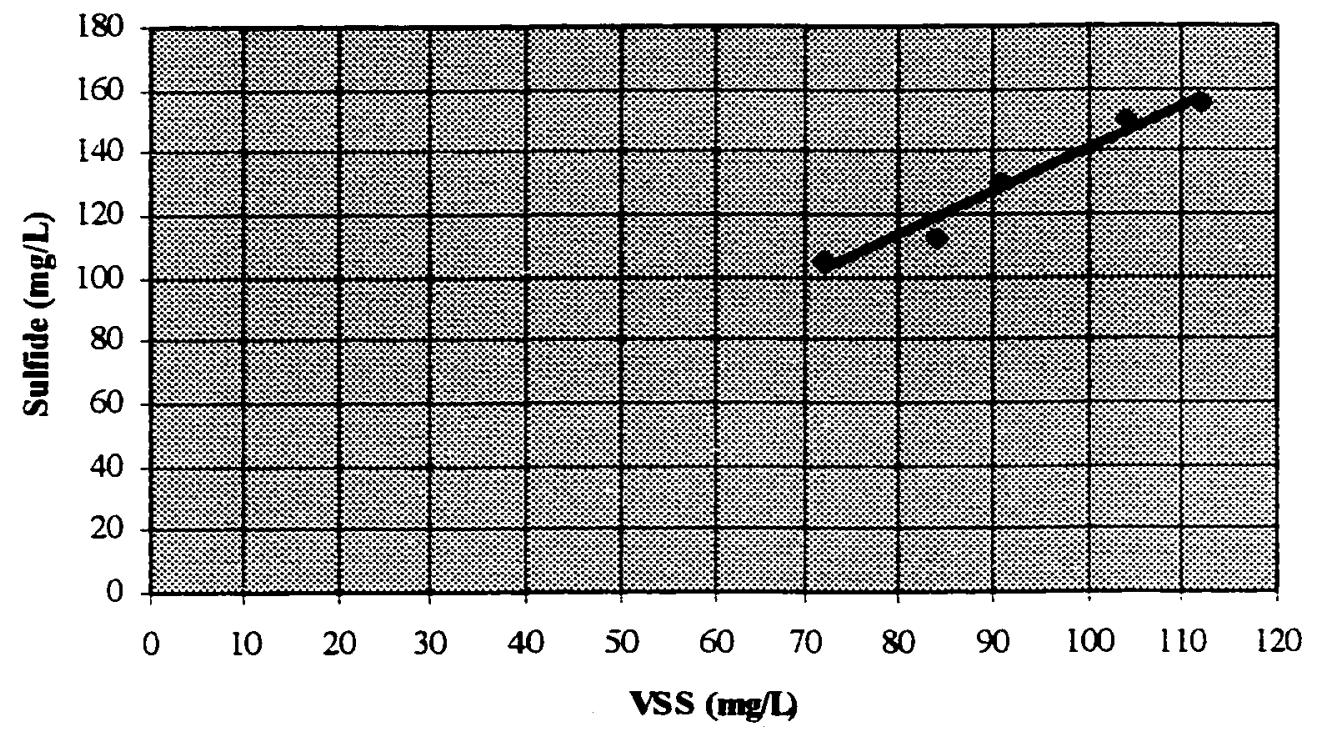

Figure 5.16 Sulfide vs VSS Concentrations for Reactor III (non-packed). $4^{\text {th }}$ sequence Sulfide $=1.37$ VSS $+3.27 \quad R^{2}=0.962$

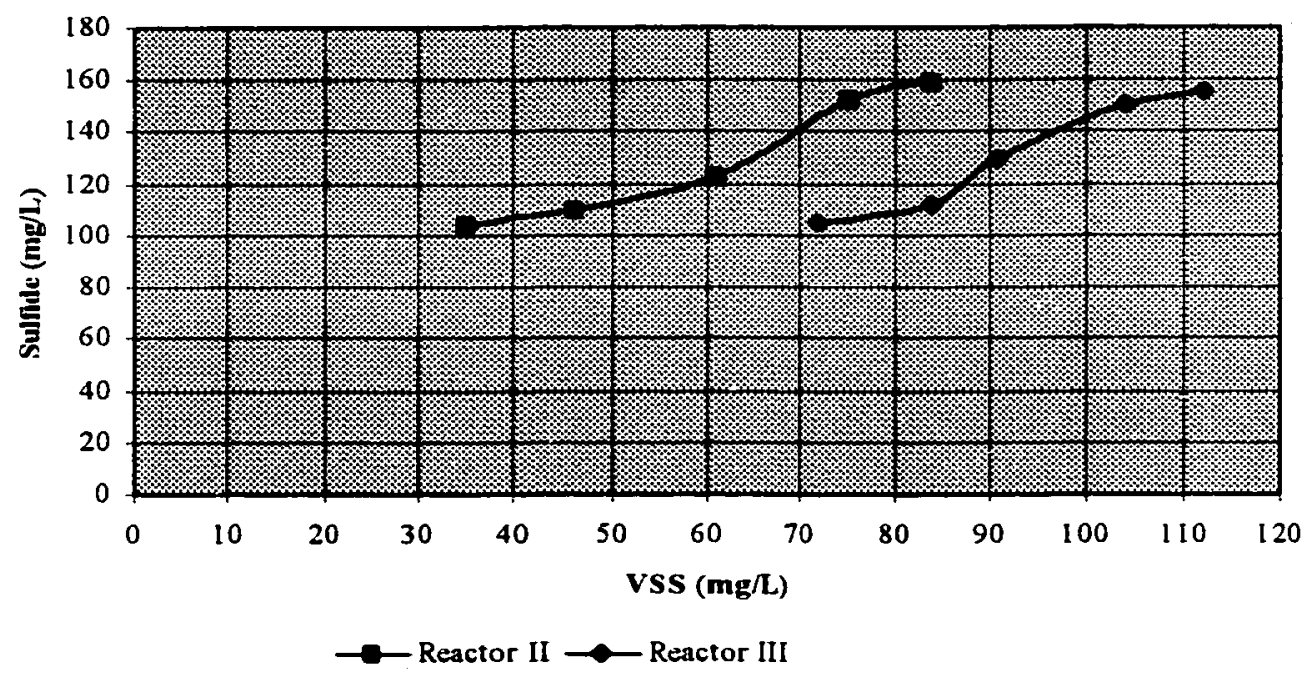

Figure 5.17 Sulfide vs VSS Concentrations for Non-Packed Reactors II and III 


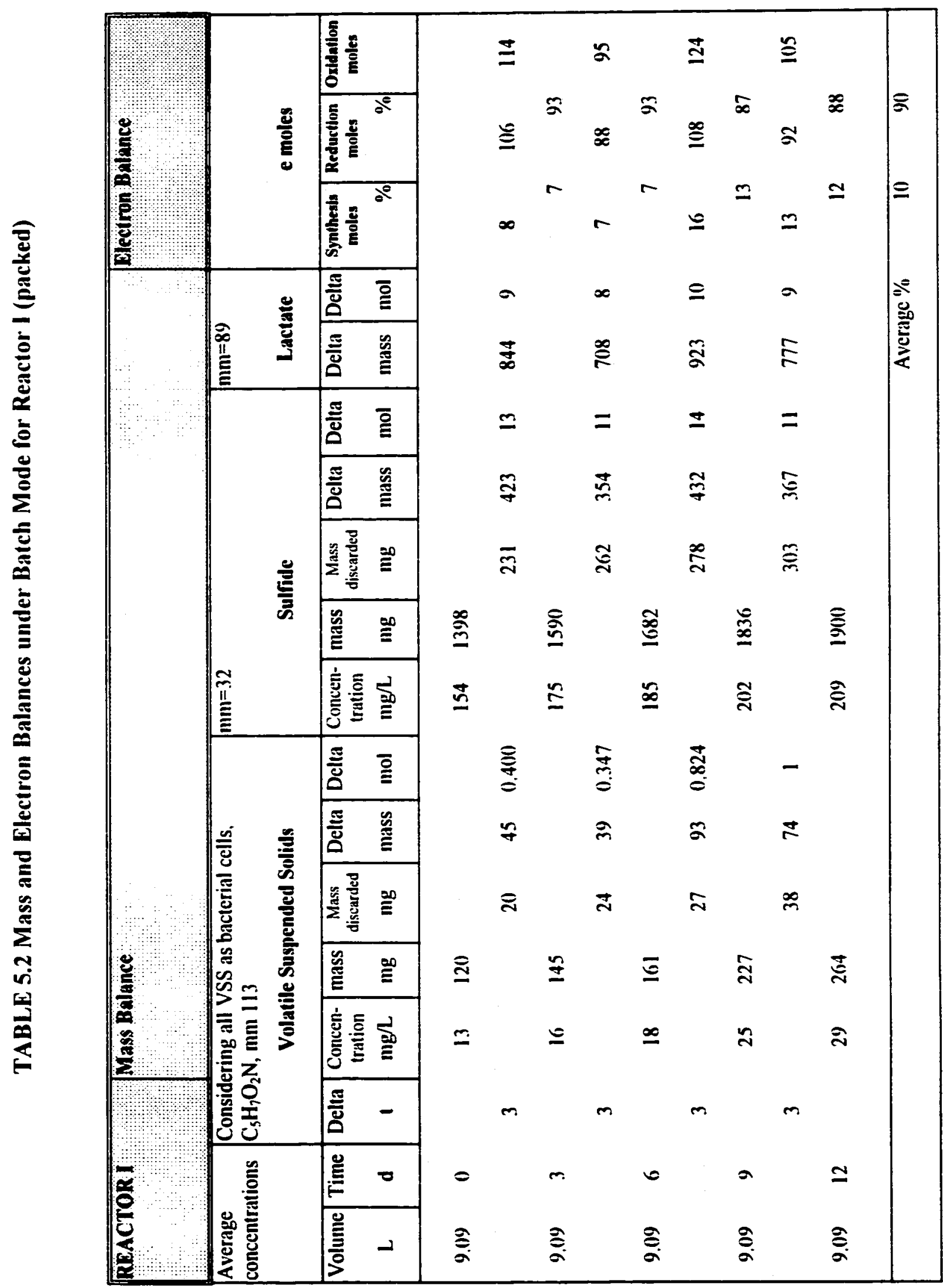




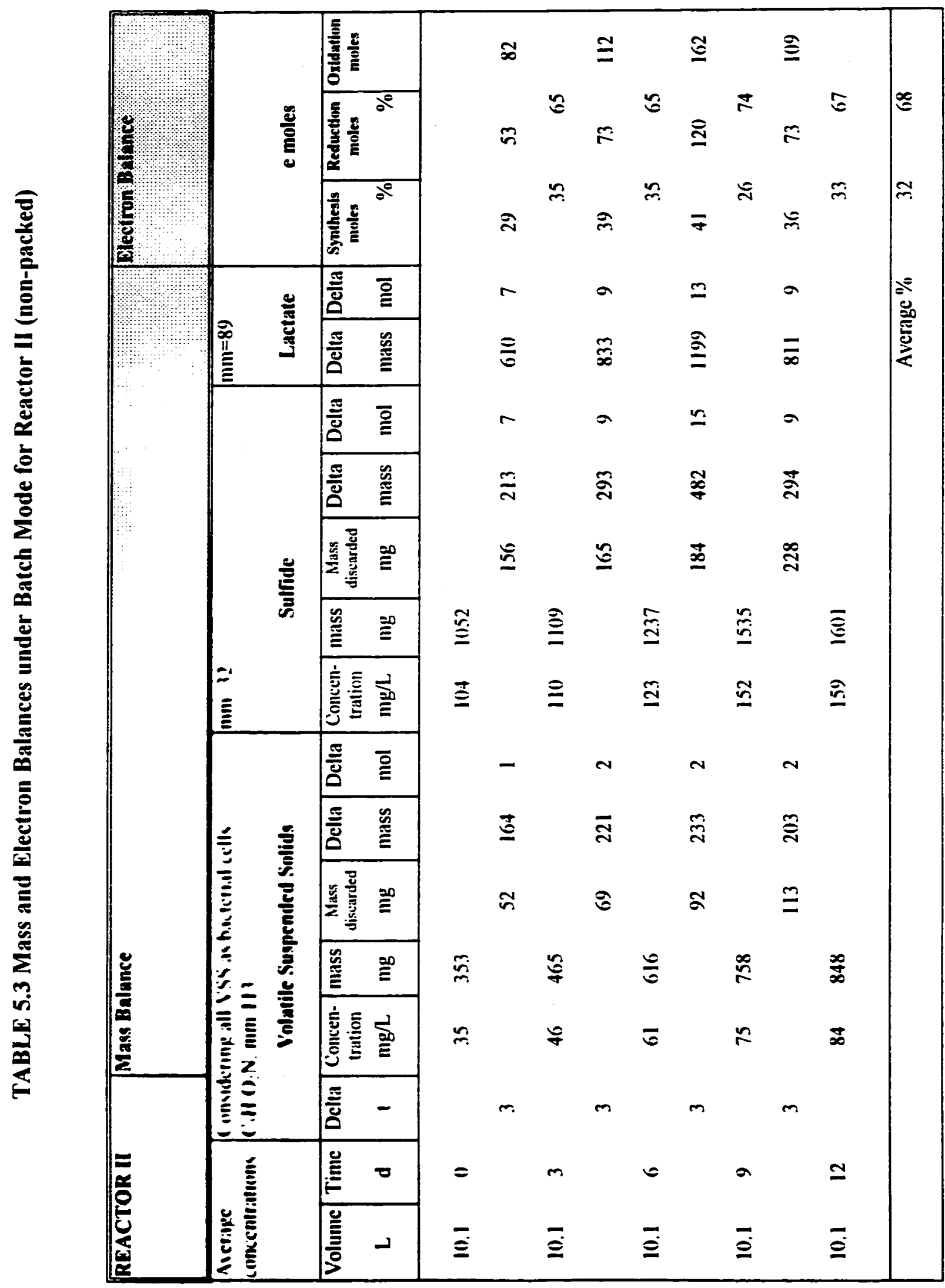




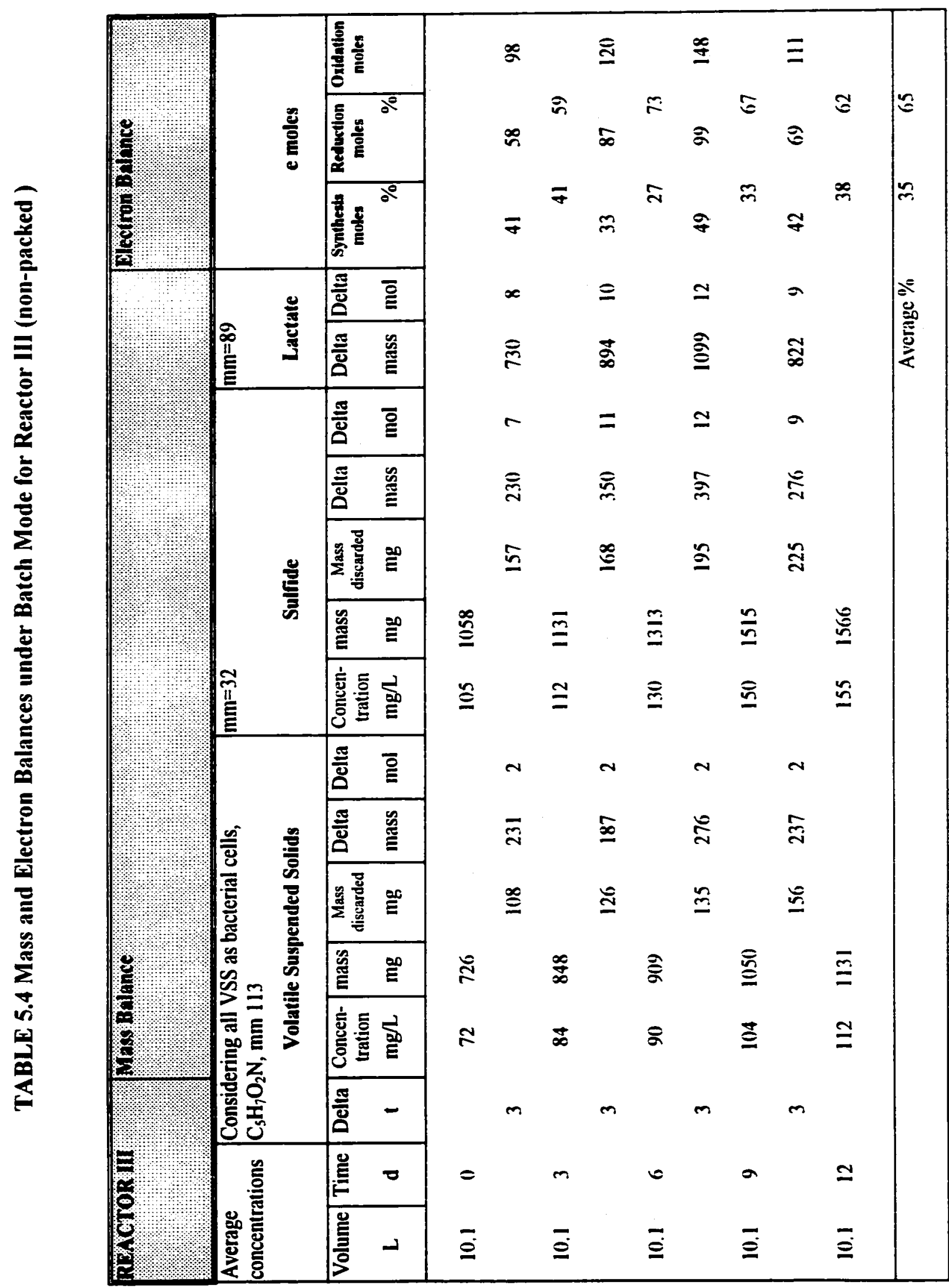




\subsection{Phase III}

The effect of packing material on the maximum sulfide production, used as an indicator of bacterial growth and performance of the reactor, was studied. Simultaneously, the effect of hydraulic retention time on the overall performance of the reactor was evaluated.

The first reactor contained packing material while the second and third had none. Seven different hydraulic retention times were tested: $50,30,20,12,10,7.5$ and $5 \mathrm{~h}$. Two organic loading rates, $6 \mathrm{~kg} / \mathrm{d} / \mathrm{m}^{3}$ and $12 \mathrm{~kg} / \mathrm{d} / \mathrm{m}^{3}$, were also tested.

\subsubsection{Set 1}

Reactor I (packed). HRT $=50 \mathrm{~h}$.

Reactor II (non-packed). HRT=50 h.

Reactor IIl (non-packed). HRT $=30 \mathrm{~h}$.

The reactors were operated for 28 days under these conditions and the organic loading rate was kept at $6 \mathrm{~kg} / \mathrm{d} / \mathrm{m}^{3}$ for the three reactors. Figures 5.18 and 5.19 show the data collected for sulfide concentrations in the effluent and first port, respectively. The steady state was reached at about 8 times the hydraulic retention time tested. Simultaneous data for the range and average of steady state VSS concentrations in effluent and first port are shown in Table 5.5. The average was calculated from the last three steady state values. 


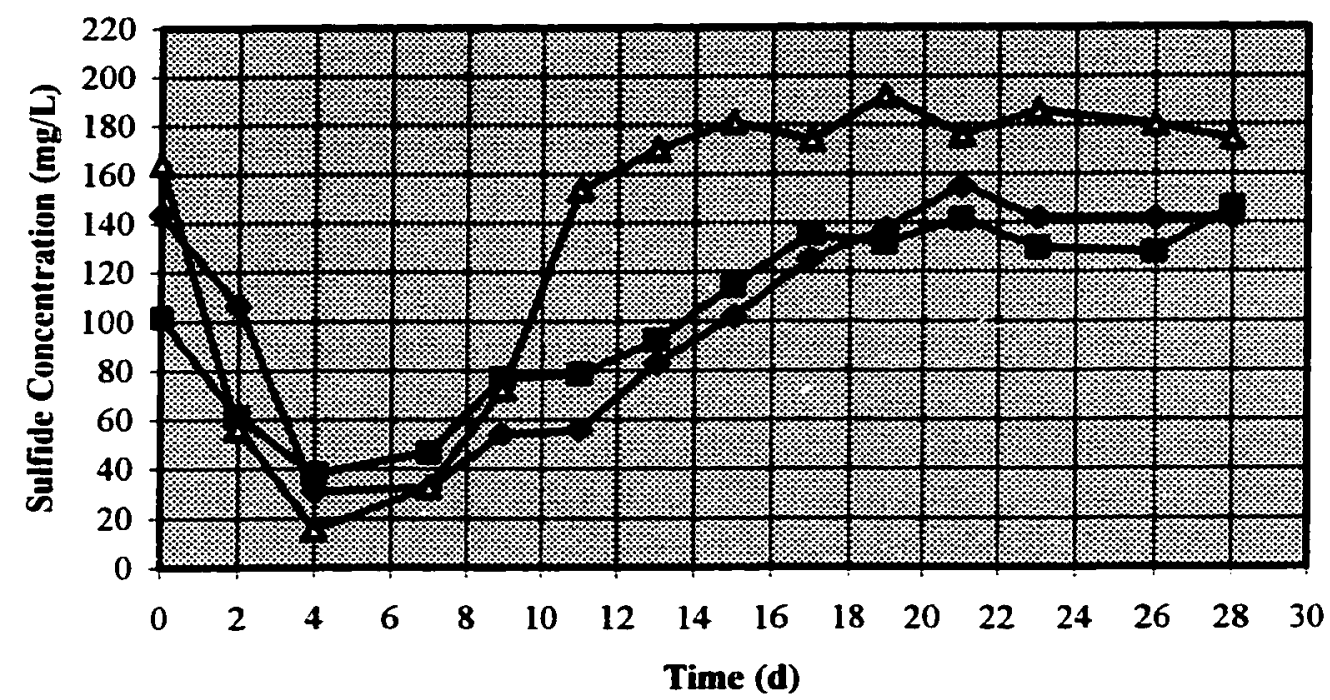

$\neg$ Reactor I (packed). HRT=50 h $\rightarrow$ Reactor II (non-packed). HRT=50 h. $\rightarrow$ Reactor III (non-packed). HRT=30 h

Figure 5.18 Effluent Sulfide Concentration vs Time During Continuous Operation (Set 1)

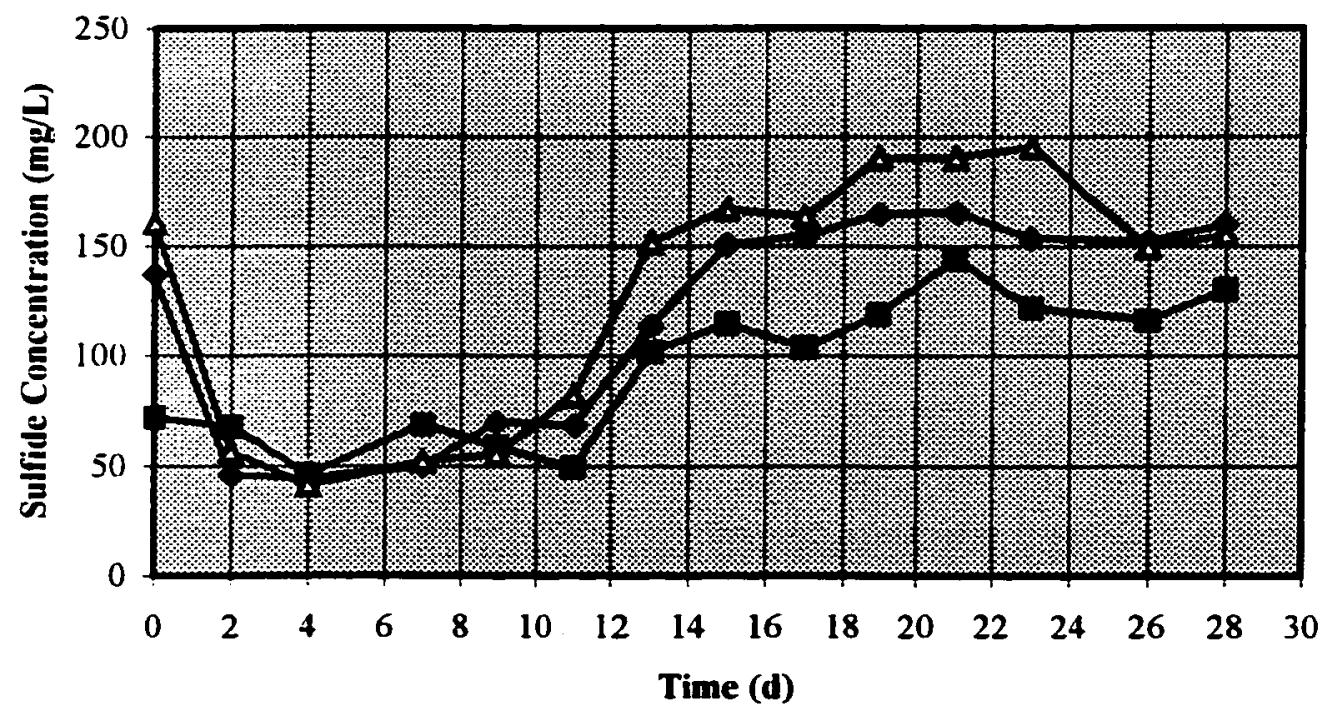

- Reactor I (packed). HRT $=50 \mathrm{~h}$.
$\rightarrow$ Reactor III (non-packed). HRT=30 h.

Figure 5.19 First Port Sulfide Concentration vs Time During Continuous Operation (Set 1) 
Table 5.5 Range and Average of Steady State VSS Concentrations (Set 1)

\begin{tabular}{|c|c|c|c|c|c|}
\hline \multirow[t]{2}{*}{ Reactor } & \multirow{2}{*}{$\frac{6}{(\mathrm{a})}$} & \multicolumn{2}{|c|}{ Worsteris sine } & \multicolumn{2}{|c|}{$\begin{array}{l}\text { Wveroseof Stendy State } \\
\text { Concentrations }\end{array}$} \\
\hline & & $\begin{array}{l}\text { Effuent VSS } \\
(m, 1)\end{array}$ & $\begin{array}{l}\text { Fint Pont } \\
\text { vss (Got) }\end{array}$ & 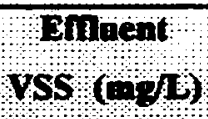 & $\begin{array}{l}\text { First Port } \\
\text { Vss (mgli) }\end{array}$ \\
\hline Reactor I (packed) & 50 & $49-80$ & $58-90$ & 63 & 81 \\
\hline Reactor II (non-packed) & 50 & $41-91$ & $50-89$ & 62 & 65 \\
\hline Reactor III (non-packed) & 30 & $15-41$ & $18-58$ & 25 & $\overline{42}$ \\
\hline
\end{tabular}

The steady state effluent sulfide concentration with $50 \mathrm{~h}$ of HRT fluctuated between 130 and $150 \mathrm{mg} / \mathrm{L}$. Similarly, the steady state sulfide concentrations near the bottom ranged between 120 and $150 \mathrm{mg} / \mathrm{L}$. Generally, the sulfide concentrations in the packed reactor were slightly higher than in the non-packed reactor when operated at the same HRT. Also, no significant difference in effluent and first port concentrations of sulfide or VSS was observed, so concentrations can be assumed to be uniform along the reactor's height. The $\mathrm{pH}$ average was around 6.0 and the ORP ranged between -310 and $-320 \mathrm{mV}$.

For the packed reactor, the steady state VSS concentration in the effluent with $50 \mathrm{~h}$ of hydraulic retention time was about $63 \mathrm{mg} / \mathrm{L}$. This was slightly lower than $81 \mathrm{mg} / \mathrm{L}$ observed at the first port, $300 \mathrm{~mm}$ above the bottom of the reactor. The concentrations of VSS both in the effluent and the first port of the three reactors are not as high as it would be expected for the concentration of sulfide present. Therefore, it is inferred that major bacterial activity was taking place at the bottom of the reactor, within the first $300 \mathrm{~mm}$, 
where the biomass had settled down. The washout of VSS was similar both for the packed reactor and for the non-packed reactor at $50 \mathrm{~h}$ of HRT.

The comparison of the results at two different HRTs, $50 \mathrm{~h}$ and $30 \mathrm{~h}$, while operating the reactors under the same organic loading rate and without packing material, shows that the effluent sulfide concentration with $30 \mathrm{~h}$ HRT had gone up to an average of $180 \mathrm{mg} / \mathrm{L}$ versus $135 \mathrm{mg} / \mathrm{L}$ with $50 \mathrm{~h} \mathrm{HRT}$, once the steady state had been reached. Also, with $30 \mathrm{~h}$ of HRT, the steady state VSS in the effluent was $25 \mathrm{mg} / \mathrm{L}$ versus $62 \mathrm{mg} / \mathrm{L}$ with $50 \mathrm{~h}$ of HRT. Again, this concentration was similar to the concentration at the first port of the reactor. It became evident that most of the biomass was active near the bottom, below $300 \mathrm{~mm}$, and there was little washout of solids at $30 \mathrm{~h}$ of HRT.

\subsubsection{Set 2}

Reactor I (packed). HRT $=30 \mathrm{~h}$.

Reactor II (non-packed). HRT=30 h.

Reactor III (non-packed). HRT=20 h.

The reactors were operated for 20 days under these conditions and the organic loading rate was kept at $6 \mathrm{~kg} / \mathrm{d} / \mathrm{m}^{3}$ for the three reactors. Figures 5.20 and 5.21 show the data collected for sulfide concentrations in the effluent and first port, respectively. The steady state was reached at about 8 times the hydraulic retention time tested. Simultaneous data for the range and average of steady state VSS concentrations in effluent and first port are shown in Table 5.6. The average was calculated from the last three steady state values. 


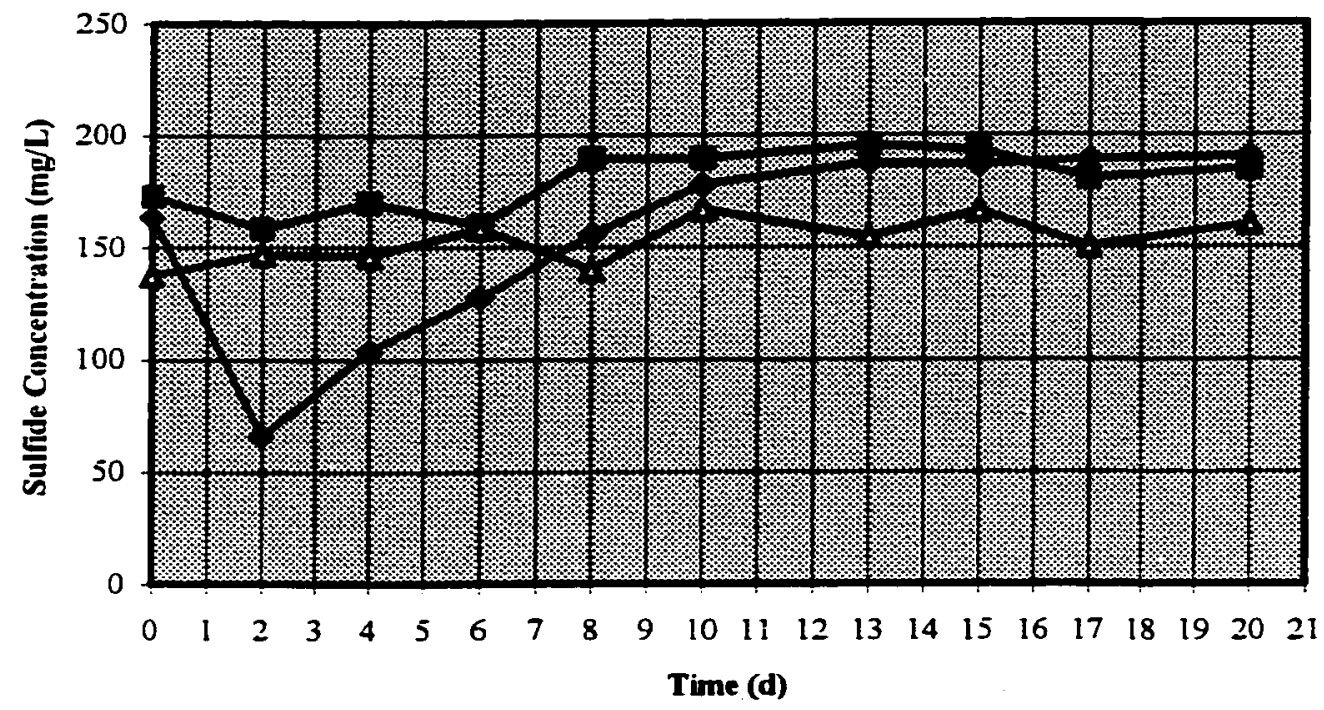

\footnotetext{
Reactor I (packed). HRT $=30 \mathrm{~h}$. $\quad-$ Reactor II (non-packed). HRT $=30 \mathrm{~h}$.

-Reactor III (non-packed). HRT $=20 \mathrm{~h}$.
}

Figure 5.20 Effluent Sulfide Concentration vs Time During Continuous Operation (Set 2)

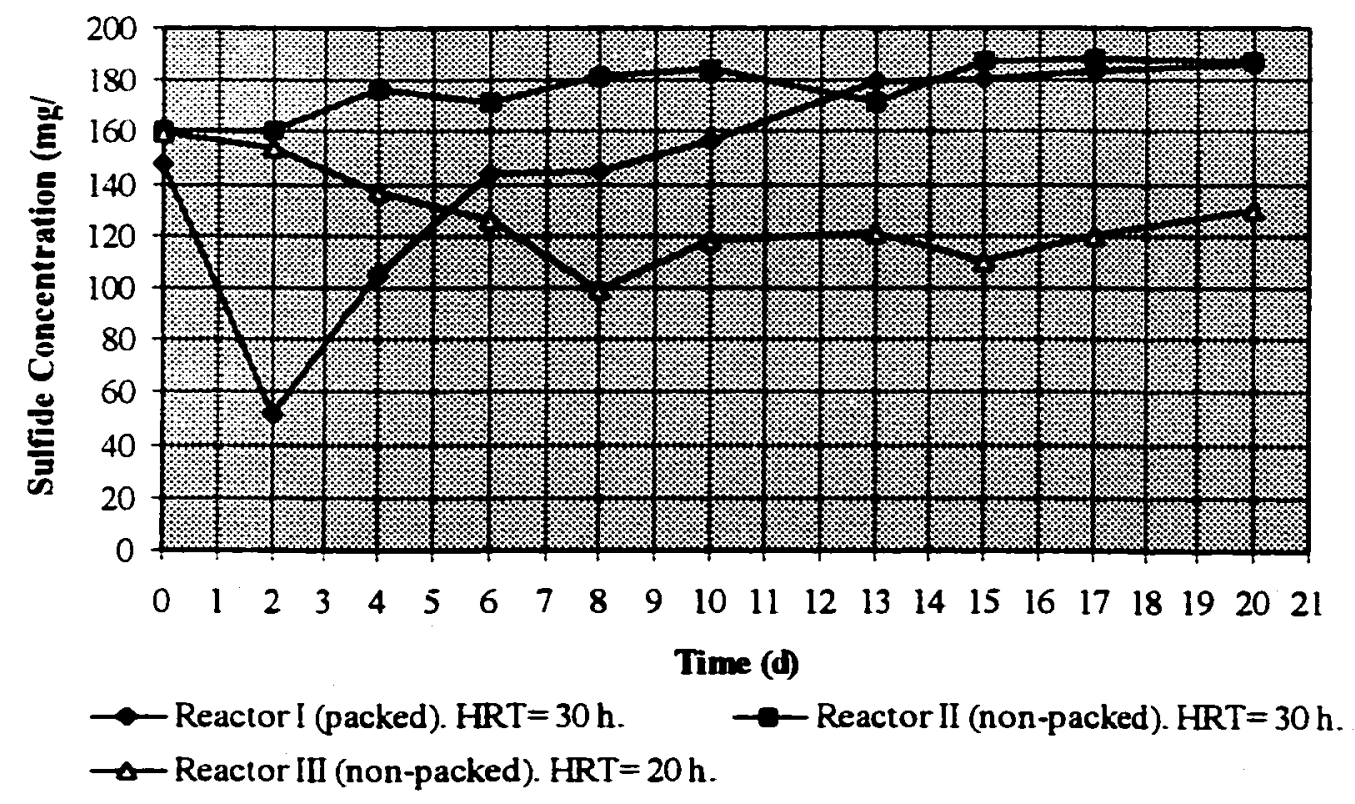

Figure 5.21 First Port Sulfide Concentration vs Time During Continuous Operation (Set 2) 
Table 5.6 Range and Average of Steady State VSS Concentrations (Set 2)

\begin{tabular}{|c|c|c|c|c|c|}
\hline Reactor & (1) & $\begin{array}{l}\text { Phige of } \\
\text { Conce }\end{array}$ & $\begin{array}{l}\text { Wrstrfe } \\
\text { hions }\end{array}$ & $\begin{array}{r}\text { Average of } \\
\text { Conce }\end{array}$ & $\begin{array}{l}\text { tendy State } \\
\text { rations }\end{array}$ \\
\hline & 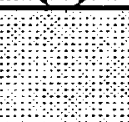 & $\begin{array}{l}\text { Finceit YSS } \\
(\text { my) })\end{array}$ & $\begin{array}{l}\text { Bintront } \\
\text { Wss }(\mathrm{med})\end{array}$ & $\begin{array}{l}\text { PMluent } \\
\text { YSS (no/4) }\end{array}$ & $\begin{array}{l}\text { First Port } \\
\text { yss (mg/L) }\end{array}$ \\
\hline Reactor I (packed) & 30 & 29.41 & $29-48$ & 34 & 38 \\
\hline Reactor II (non-packed) & 30 & $7-17$ & $15-42$ & 13 & 39 \\
\hline Reactor III (non-packed) & 20 & $13-22$ & $20-36$ & 18 & 30 \\
\hline
\end{tabular}

The steady state sulfide concentrations for the reactors, packed and non-packed, operated at $30 \mathrm{~h}$ of HRT ranged between $180-190 \mathrm{mg} / \mathrm{L}$ and the concentrations at the effluent and first port were fairly close. The steady state VSS concentration was $34 \mathrm{mg} / \mathrm{L}$ for the packed reactor at $30 \mathrm{~h} \mathrm{HRT}$ and $13 \mathrm{mg} / \mathrm{L}$ for the non-packed reactor at the same hydraulic retention tume of $30 \mathrm{~h}$. The $\mathrm{pH}$ varied between 6.0 and 7.0 and the ORP ranged between -340 and $-390 \mathrm{mV}$. Thus, the behavior of the two reactors is considered to be similar between them and also to Reactor III of Set 1 operated under the same conditions.

The non-packed reactor operating at $20 \mathrm{~h}$ of HRT showed a steady state sulfide concentration of $160 \mathrm{mg} / \mathrm{L}$ for the effluent sample while it was $120 \mathrm{mg} / \mathrm{L}$ for the first port. The corresponding steady state VSS concentrations for the effluent and first port were $18 \mathrm{mg} / \mathrm{L}$ and $30 \mathrm{mg} / \mathrm{L}$, respectively. Therefore, the differences between the effluent and first port, both for sulfide and VSS concentrations, had become more significant with an increase in the upflow velocity. Although the sulfide concentrations had decreased at this higher flow rate and lower hydraulic retention time, the performance of the reactor 
was acceptable and the washout of biomass was low. Further experiments were conducted at lower HRT in order to find out the critical flow rate at which the biomass would be washed out from the reactor.

\subsubsection{Set 3}

Reactor I (packed). HRT $=20 \mathrm{~h}$.

Reactor II (non-packed). HRT $=20 \mathrm{~h}$.

Reactor III (non-packed). HRT=10 h.

The reactors were operated for 13 days under these conditions and the organic loading rate was kept at $6 \mathrm{~kg} / \mathrm{d} / \mathrm{m}^{3}$ for the three reactors. Figures 5.22 and 5.23 show the data collected for sulfide concentrations in the effluent and first port, respectively. The steady state was reached at about 5 times the hydraulic retention time tested. Simultaneous data for the range and average of steady state VSS concentrations in effluent and first port are shown in Table 5.7. The average was calculated from the last three steady state values.

The non-packed reactor operating at $20 \mathrm{~h}$ of HRT showed a steady state sulfide concentration of $182 \mathrm{mg} / \mathrm{L}$ for the effluent sample while it was $160 \mathrm{mg} / \mathrm{L}$ for the first port. The $\mathrm{pH}$ and ORP were about 7.0 and $-380 \mathrm{mV}$, respectively. The washout of VSS remained fairly low, 10-20 $\mathrm{mg} / \mathrm{L}$, both for the packed reactor and the non-packed reactor. The results confirmed the similar behavior of the packed and the non-packed reactors. 


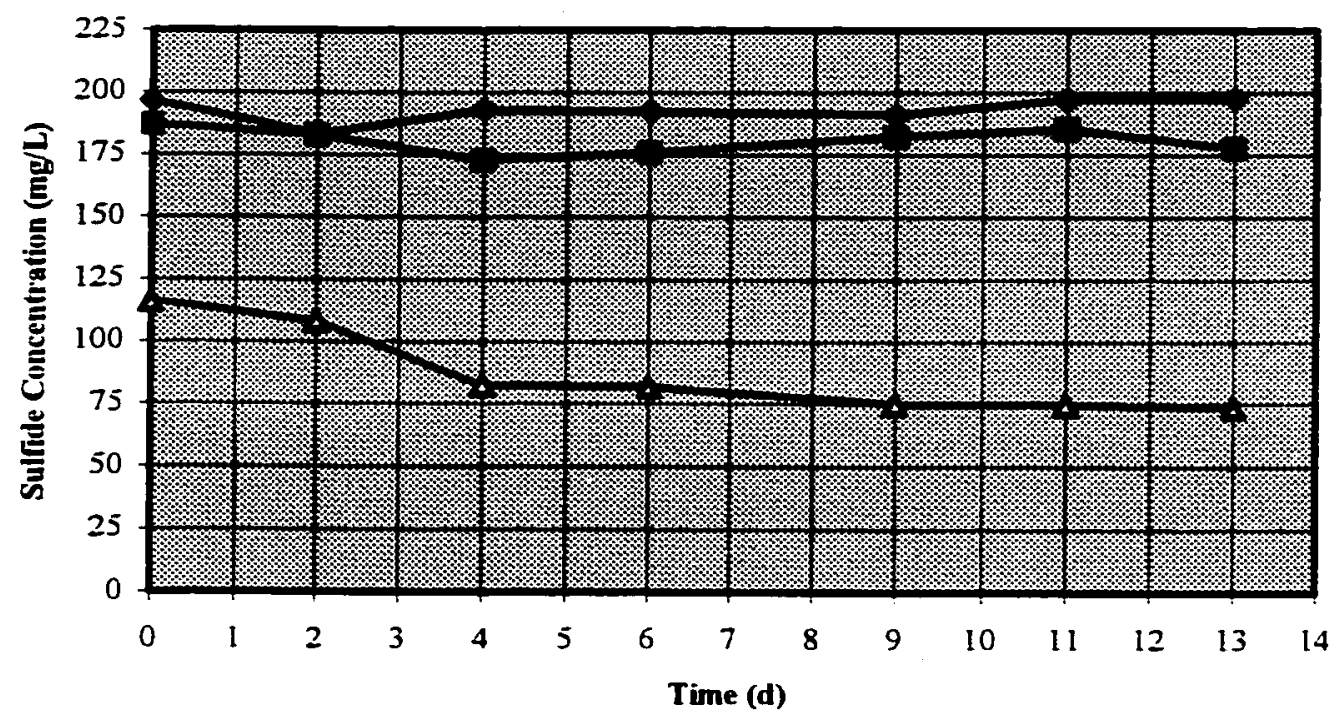

Reactor I (packed). HRT $=20 \mathrm{~h}$.
- Reactor III (non-packed). HRT $=10 \mathrm{~h}$.

Figure 5.22 Effluent Sulfide Concentration vs Time During Continuous Operation (Set 3)

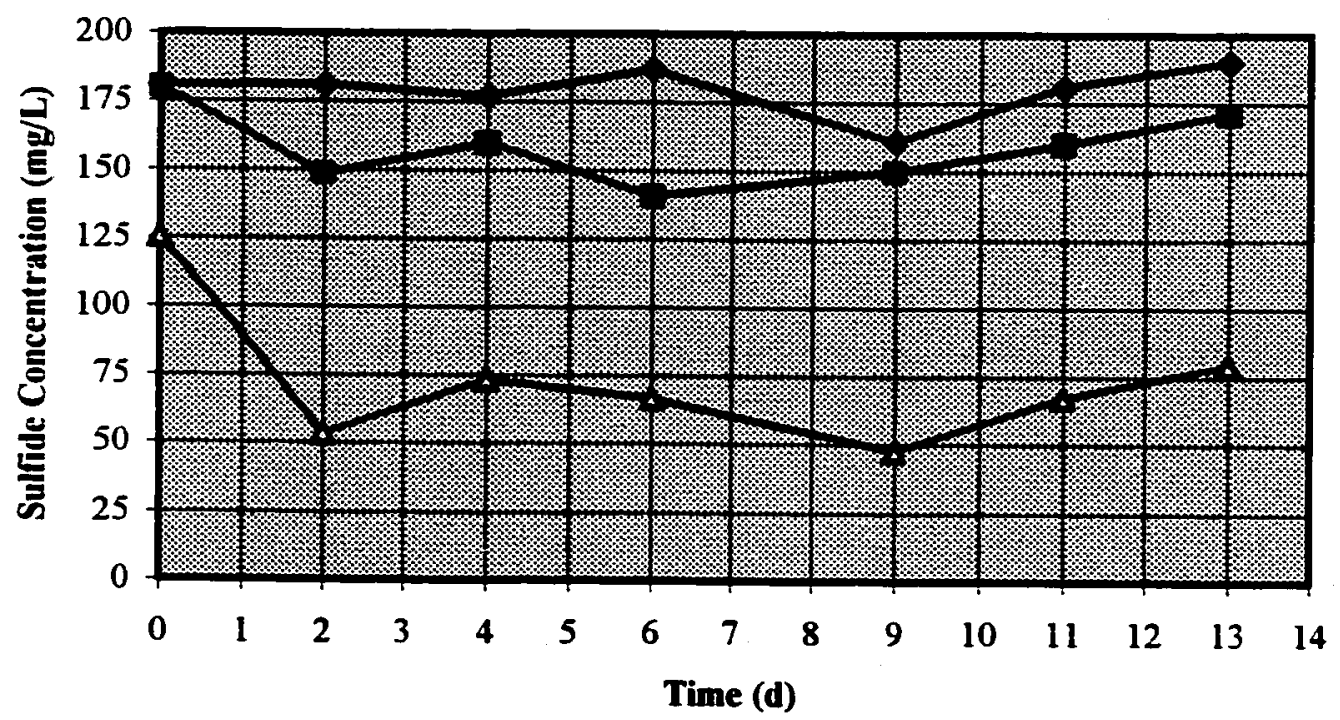

\footnotetext{
-Reactor I (packed). HRT $=20 \mathrm{~h} . \quad \rightarrow-$ Reactor II (non-packed). HRT $=20 \mathrm{~h}$.

$\longrightarrow$ Reactor III (non-packed). HRT= $10 \mathrm{~h}$.
}

Figure 5.23 First Port Sulfide Concentration vs Time During Continuous Operation (Set 3) 
Table 5.7 Range and Average of Steady State VSS Concentrations (Set 3)

\begin{tabular}{|c|c|c|c|c|c|}
\hline \multirow[t]{3}{*}{ Reactor } & \multirow{2}{*}{$\begin{array}{l}\text { FIRT } \\
\text { (h) }\end{array}$} & \multicolumn{2}{|c|}{ Papeorstedy State } & \multicolumn{2}{|c|}{ Ayerage of steady State } \\
\hline & & Cone: & ations & Conce & trations \\
\hline & & $\begin{array}{l}\text { Bnipentrss } \\
(\text { mef })\end{array}$ & 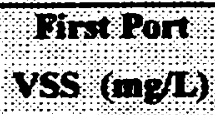 & $\begin{array}{l}\text { Emuent } \\
\text { VSS (ng/h) }\end{array}$ & $\begin{array}{l}\text { Firnt Port } \\
\text { uss (mg/L) }\end{array}$ \\
\hline Reactor I (packed) & 20 & $16-24$ & $15-26$ & 16 & 25 \\
\hline Reactor II (non-packed) & 20 & $10-16$ & $16-36$ & 11 & 30 \\
\hline Reactor III (non-packed) & 10 & $16-23$ & $11-41$ & 18 & 17 \\
\hline
\end{tabular}

The comparison of the results at two different HRTs, 20 and $10 \mathrm{~h}$, while operating the reactors under the same conditions, shows that the steady state effluent sulfide concentration with $10 \mathrm{~h}$ HRT had gone down to $74 \mathrm{mg} / \mathrm{L}$, which represents less than half of the stead! statc effluent sulfide concentration with $20 \mathrm{~h} \mathrm{HRT}, 182 \mathrm{mg} / \mathrm{L}$. However, the effluent ISS concentrations between these two hydraulic retention times were not significantly different

\subsubsection{Set 4}

Reactor II (non-packed). HRT $=10 \mathrm{~h}\left(\mathrm{OLR}=12 \mathrm{~kg} / \mathrm{d} / \mathrm{m}^{3}\right)$

Reactor III (non-packed). HRT $=5 \mathrm{~h}\left(\mathrm{OLR}=6 \mathrm{~kg} / \mathrm{d} / \mathrm{m}^{3}\right)$

In order to accomplish the objective of finding the critical flow rate at which the bacteria would be washed out from the anaerobic reactor, only two non-packed reactors were operated for 10 days under the above conditions, because the packing material did not represent a significant advantage in the performance of the reactors. Figures 5.24 and 
5.25 show the data collected for sulfide concentrations in the effluent and first port, respectively. Simultaneous data for the range and average of steady state VSS concentrations in effluent and first port are shown in Table 5.8. The average was calculated from the last three steady state values.

The steady state effluent sulfide concentration of $165 \mathrm{mg} / \mathrm{L}$ observed with $10 \mathrm{~h} \mathrm{HRT}$ and $12 \mathrm{~kg} / \mathrm{d} / \mathrm{m}^{3}$ OLR was nearly twice the steady state effluent sulfide concentration of 74 $\mathrm{mg} / \mathrm{L}$ observed with $10 \mathrm{~h} \mathrm{HRT}$ and $6 \mathrm{~kg} / \mathrm{d} / \mathrm{m}^{3}$ OLR.

The flow rate for $10 \mathrm{~h} \mathrm{HRT}$ was found to be critical for the sulfide production up to the first port, where the steady state sulfide concentrations remained between $50-60 \mathrm{mg} / \mathrm{L}$, for both organic loading rates. When the HRT was reduced to $5 \mathrm{~h}$, a complete washout of the bacteria took place in the Reactor III within 48 hours and therefore its operation was stopped.

The difference in sulfide or VSS concentrations at different reactor's height was more evident for the reditor with a HRT of $10 \mathrm{~h}$ and OLR of $12 \mathrm{~kg} / \mathrm{d} / \mathrm{m}^{3}$. The steady state sulfide concentration in the effluent was $165 \mathrm{mg} / \mathrm{L}$ versus $53 \mathrm{mg} / \mathrm{L}$ in the first port. Similarly, the steads state VSS concentrations were not uniform between the two sampling points 


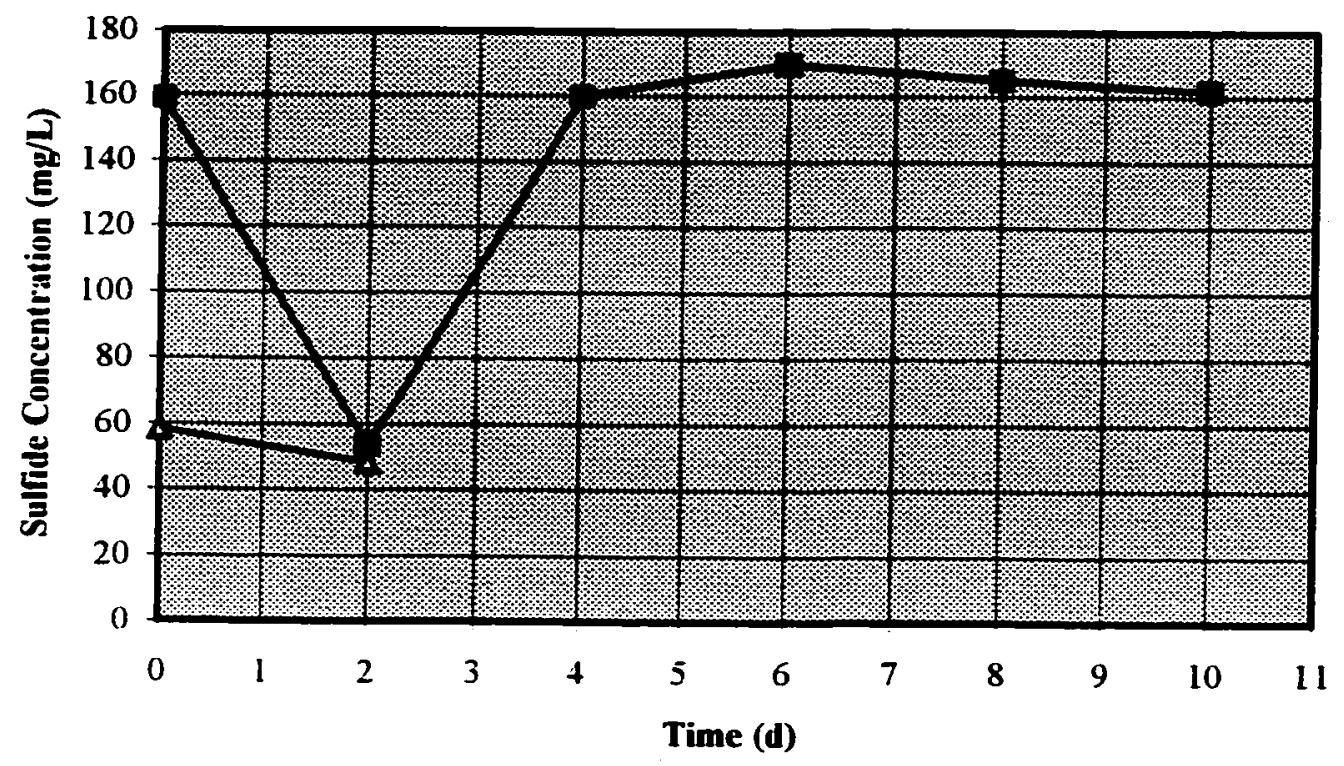

Reactor II (non-packed). HRT= $10 \mathrm{~h} \longrightarrow$ Reactor III (non-packed). HRT $=5 \mathrm{~h}$

Figure 5.24 Emuent Sulfide Concentration vs Time During Continuous Operation (Set 4)

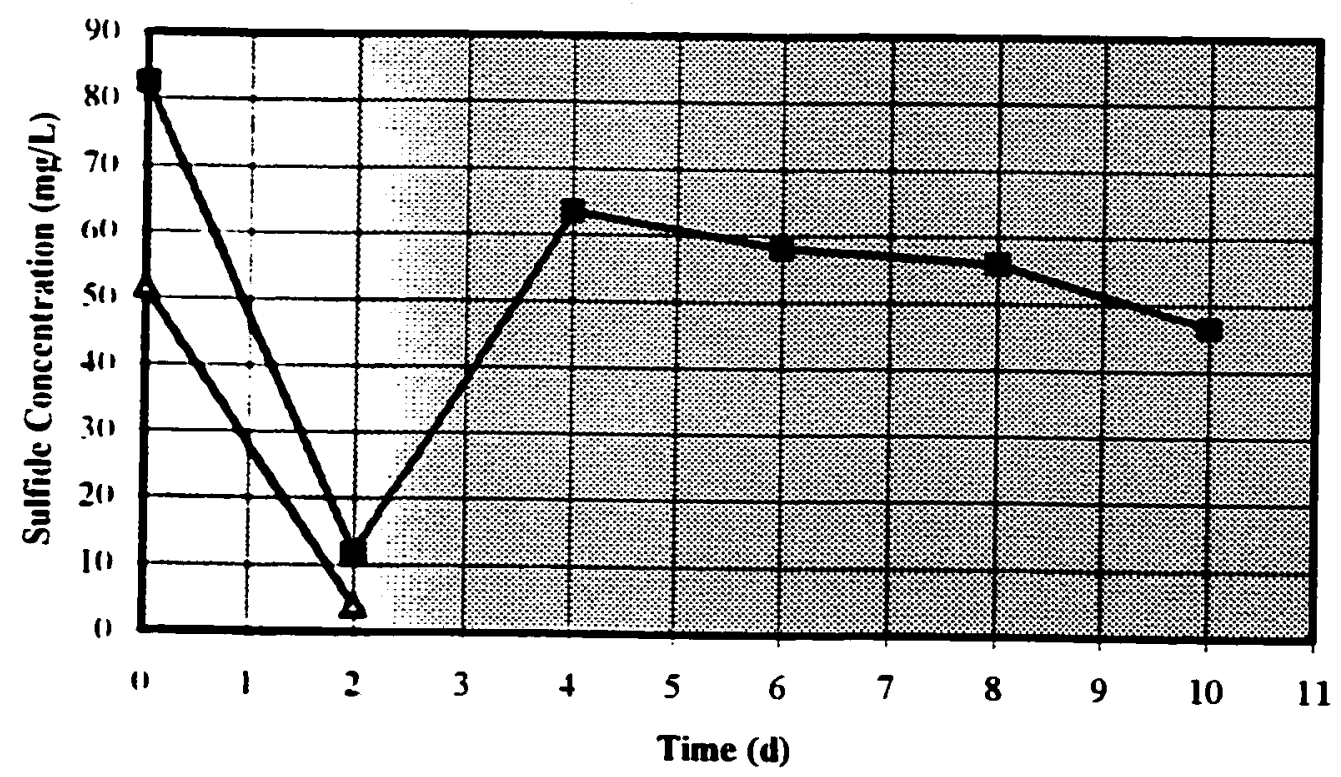

$\rightarrow$-Reactor II (non-packed). HRT=10 h. Reactor III (non-packed). HRT=5 h.

Figure 5.25 First Port Sulfide Concentration vs Time During Continuous Operation (Set 4) 
Table 5.8 Range and Average of Steady State VSS Concentrations (Set 4)

\begin{tabular}{|c|c|c|c|c|c|}
\hline \multirow[t]{2}{*}{ Reactor 140} & \multirow{2}{*}{ (b) } & \multicolumn{2}{|c|}{ 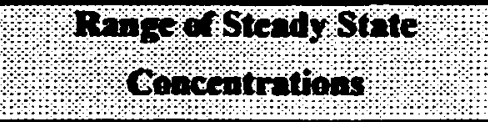 } & \multicolumn{2}{|c|}{$\begin{array}{l}\text { Averoge of Stesdy State } \\
\text { Concentrations }\end{array}$} \\
\hline & & 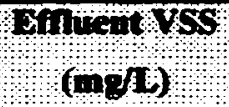 & $\begin{array}{l}\text { Grut Pot } \\
\text { ros (mgl) }\end{array}$ & $\begin{array}{l}\text { Shloent } \\
\text { VSS (mph) }\end{array}$ & $\begin{array}{l}\text { Tirst Port } \\
\text { USS (mg/L) }\end{array}$ \\
\hline Reactor II (non-packed) & 10 & $29-30$ & $30-65$ & 29 & 54 \\
\hline Reactor III (non-packed) & 5 & NA* $^{*}$ & $\mathbf{N A}^{*}$ & $\mathbf{N A}^{*}$ & $\mathbf{N A}^{*}$ \\
\hline
\end{tabular}

*Steady state condition was not reached due to continuous washout of biomass

\subsubsection{Set 5}

Reactor II (non-packed). HRT $=12 \mathrm{~h}$; OLR $12 \mathrm{~kg} / \mathrm{d} / \mathrm{m}^{3}$.

Reactor II (non-packed). HRT=7.5 h; OLR $12 \mathrm{~kg} / \mathrm{d} / \mathrm{m}^{3}$.

In order to confirm the previous findings, it was decided to test $12 \mathrm{~h}$ and $7.5 \mathrm{~h}$ of HRT at

$12 \mathrm{~kg} / \mathrm{d} / \mathrm{m}^{3}$. This set of conditions was carried out in Reactor II (non-packed) since Reactor III (non-packed) had low biomass concentration as a consequence of its washout at $5 \mathrm{~h}$ of HRT previously tested. Figures 5.26 and 5.27 show the data collected for sulfide concentrations in the effluent and first port, respectively. Simultaneous data for the average of steady state VSS concentrations in effluent and first port are shown in Table 5.9. The average was calculated from the last three steady state values.

The non-packed reactor with $12 \mathrm{~h}$ HRT showed a better performance because the sulfide concentrations both in the effluent and first port were higher than the sulfide 
concentrations reached at a higher flow rate and therefore a smaller HRT of $7.5 \mathrm{~h}$. Since Set 5 was carried out immediately after Set 4 and the difference between the flow rates was not considerable, the reactor had reached the steady state quite fast. However, there were significant fluctuations in the first port sulfide concentrations. Decreasing the flow rate and, therefore, increasing the HRT from 10 to $12 \mathrm{~h}$, while operating the reactors under the same organic loading rate of $12 \mathrm{~kg} / \mathrm{d} / \mathrm{m}^{3}$, increased the effluent sulfide concentration from 165 to $193 \mathrm{mg} / \mathrm{L}$ and the VSS washout was reduced from 30 to 26 $\mathrm{mg} / \mathrm{L}$. The difference in the effluent and first port sulfide concentrations for the reactor with $12 \mathrm{~h} \mathrm{HRT}$ and $12 \mathrm{~kg} / \mathrm{d} / \mathrm{m}^{3}$ ORL was significant, $193 \mathrm{mg} / \mathrm{L}$ for the effluent and 121 $\mathrm{mg} / \mathrm{L}$ for the first port. A similar difference was also observed in the VSS concentrations, $26 \mathrm{mg} / \mathrm{L}$ for the effluent and $45 \mathrm{mg} / \mathrm{L}$ for the first port.

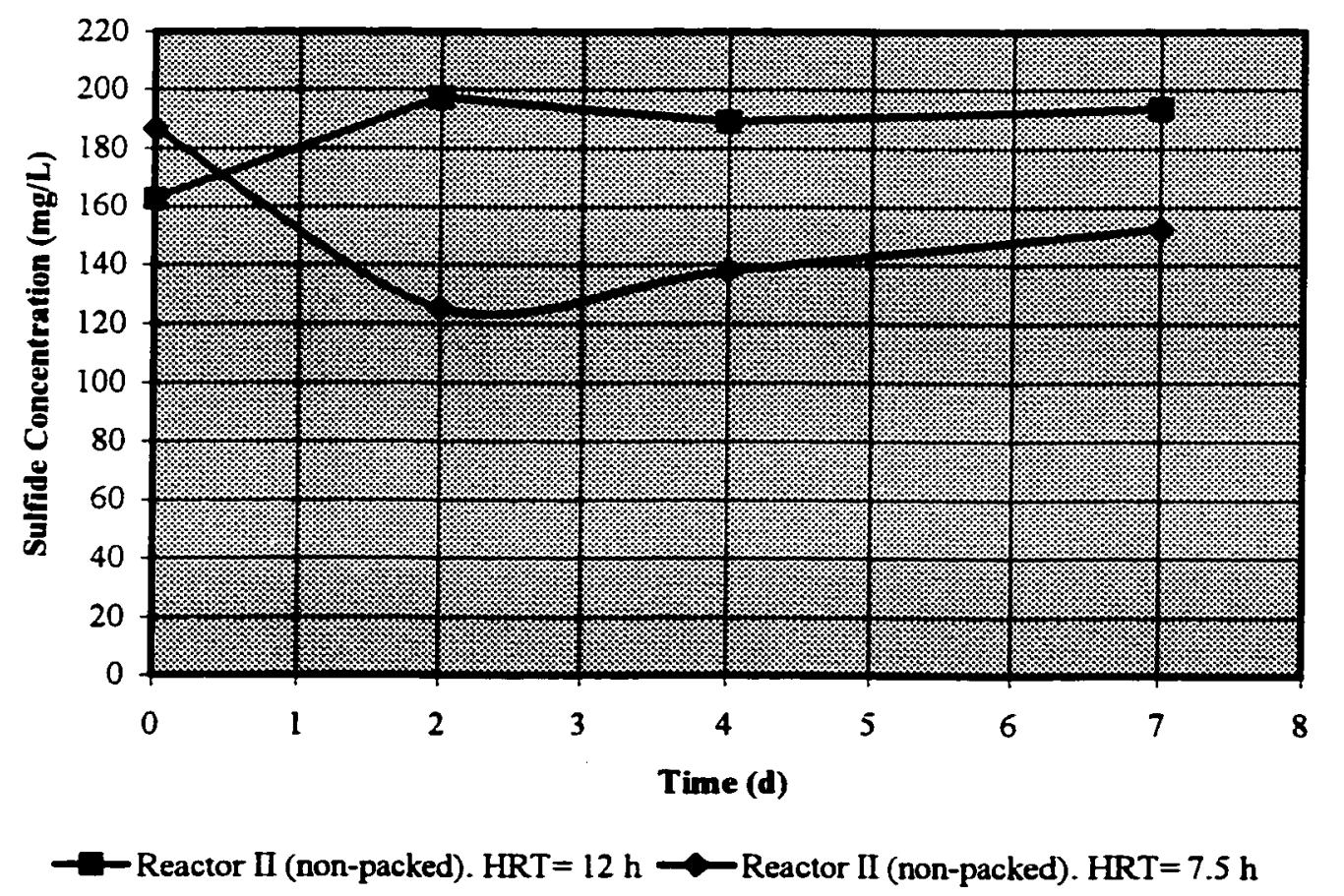

Figure 5.26 Efmuent Sulfide Concentration vs Time During Continuous Operation (Set 5) 


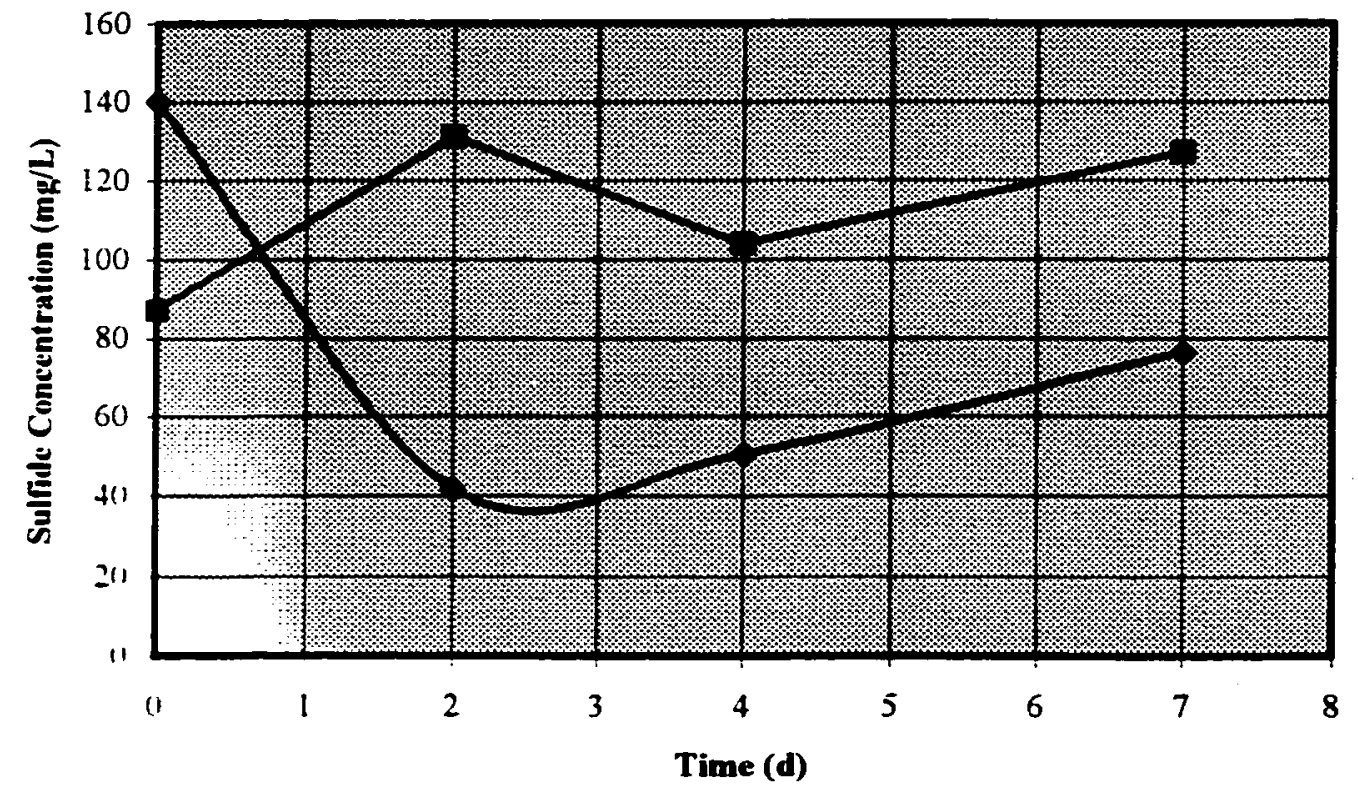

-Kcistur II Inon-packed). HRT $=12 \mathrm{~h} \rightleftharpoons$ Reactor II (non-packed). HRT $=7.5 \mathrm{~h}$

Figure 5.27 First Port Sulfide Concentration vs Time During Continuous Operation (Set 5)

Table 5.9 Average of Steady State VSS Concentrations (Set 5)

\begin{tabular}{|c|c|c|c|}
\hline \multirow{2}{*}{ Reactor } & \multirow{2}{*}{$\begin{array}{l}\text { BRT } \\
\text { (h) }\end{array}$} & \multicolumn{2}{|c|}{ Average of Stenty Stite cobcentrations } \\
\hline & & Sfruent YSS (urrs) & Mrotroxlyss (mg/L) \\
\hline Reactor II (non-packed) & 12 & 26 & 45 \\
\hline Reactor II (non-packed) & 7.5 & 19 & 17 \\
\hline
\end{tabular}


Increasing the flow and decreasing the HRT from 10 to $7.5 \mathrm{~h}$, while operating the reactors under the same organic loading rate of $12 \mathrm{~kg} / \mathrm{d} / \mathrm{m}^{3}$, showed a change in the effluent sulfide concentration from 165 to $138 \mathrm{mg} / \mathrm{L}$. One interesting observation was that the VSS concentration had become uniform along the reactor's height, 19 and 17 $\mathrm{mg} / \mathrm{L}$ for the effluent and first port, respectively. The low VSS concentrations indicated the washout of the bacteria within a short period of time and thus the lack of solids in the reactor.

The $\mathrm{pH}$ ranged between 6.0 and 7.0 and the ORP varied between -320 and $-370 \mathrm{mV}$. The SRB concentration was checked at the end of each run and it remained above $10^{6}$ cells $/ \mathrm{mL}$ in the three reactors. The VSS to SS ratio varied between 0.7 and 0.8 throughout the experiments in Phase 111 in the three reactors.

Table 5.10 summarizes the results obtained during all five sets under different operating conditions. Figures 528.529 and 5.30 show the results for steady state sulfide and VSS concentrations fir edich reactor at different hydraulic retention times and organic loading rates. The sulfide and ISS concentrations represent the average of the last three values obtained during the steady state operation of the reactors. Figure 5.31 shows the average curves for Reactor II and III, both non-packed, at different HRTs and OLRs.

Similar calculatıons of the rate of mass production for sulfide and VSS are summarized in Table 5.11 and plotted in Figures 5.32, 5.33 and 5.34. Figure 5.35 shows the average curves for Reactor II and III, both non-packed, at different HRTs and OLRs. 
Table 5.10 Summary of Steady State Sulfide and VSS Concentrations During Continuous Operation (Phase III)

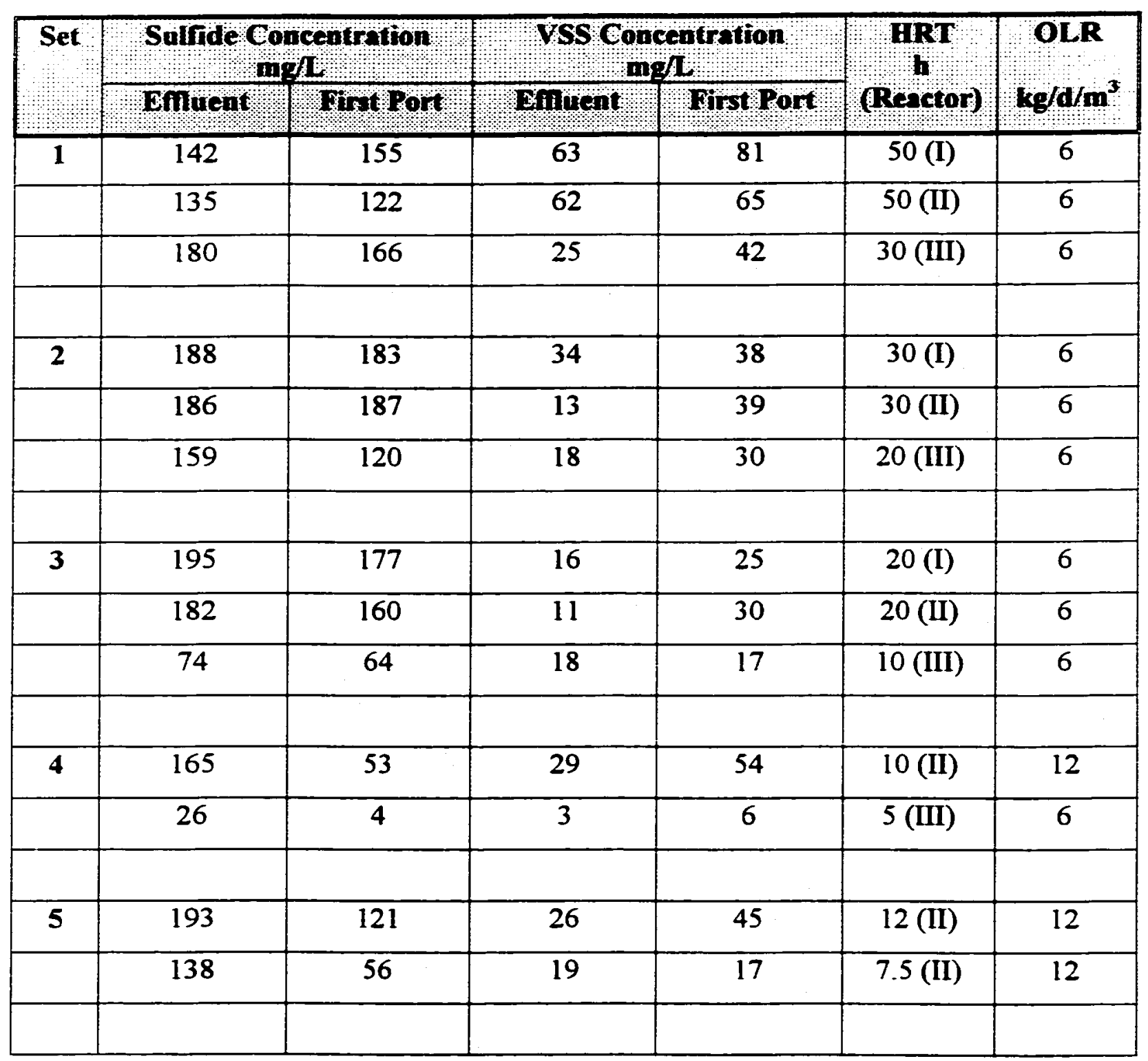


Table 5.11 Summary of the Rate of Mass Production for Sulfide and VSS During Continuous Operation (Phase III)

\begin{tabular}{|c|c|c|c|c|}
\hline$\overline{\text { Set }}$ & $\begin{array}{l}\text { Rate of Sulnde } \\
\text { Production } \\
\text { mg/d }\end{array}$ & $\begin{array}{l}\text { Rate of VSS } \\
\text { Production } \\
\text { mg/d }\end{array}$ & $\begin{array}{c}\text { HRT } \\
\text { (Reactor) }\end{array}$ & OLRR \\
\hline \multirow[t]{3}{*}{1} & 771 & 344 & 50 (I) & 6 \\
\hline & 731 & 335 & 50 (II) & 6 \\
\hline & 1485 & 208 & 30 (III) & 6 \\
\hline \multirow[t]{3}{*}{2} & 1613 & 289 & $30(\mathrm{I})$ & 6 \\
\hline & 1577 & 112 & 30 (II) & 6 \\
\hline & 1925 & 222 & 20 (III) & 6 \\
\hline \multirow[t]{3}{*}{3} & 2451 & 205 & 20 (I) & 6 \\
\hline & 2305 & 135 & 20 (II) & 6 \\
\hline & 1698 & 417 & 10 (III) & 6 \\
\hline \multirow[t]{2}{*}{4} & 3815 & 675 & 10 (II) & 12 \\
\hline & 1261 & 146 & 5 (III) & 6 \\
\hline \multirow[t]{2}{*}{5} & 3820 & 511 & 12 (II) & 12 \\
\hline & 4478 & 630 & 7.5 (II) & 12 \\
\hline & & & & \\
\hline
\end{tabular}




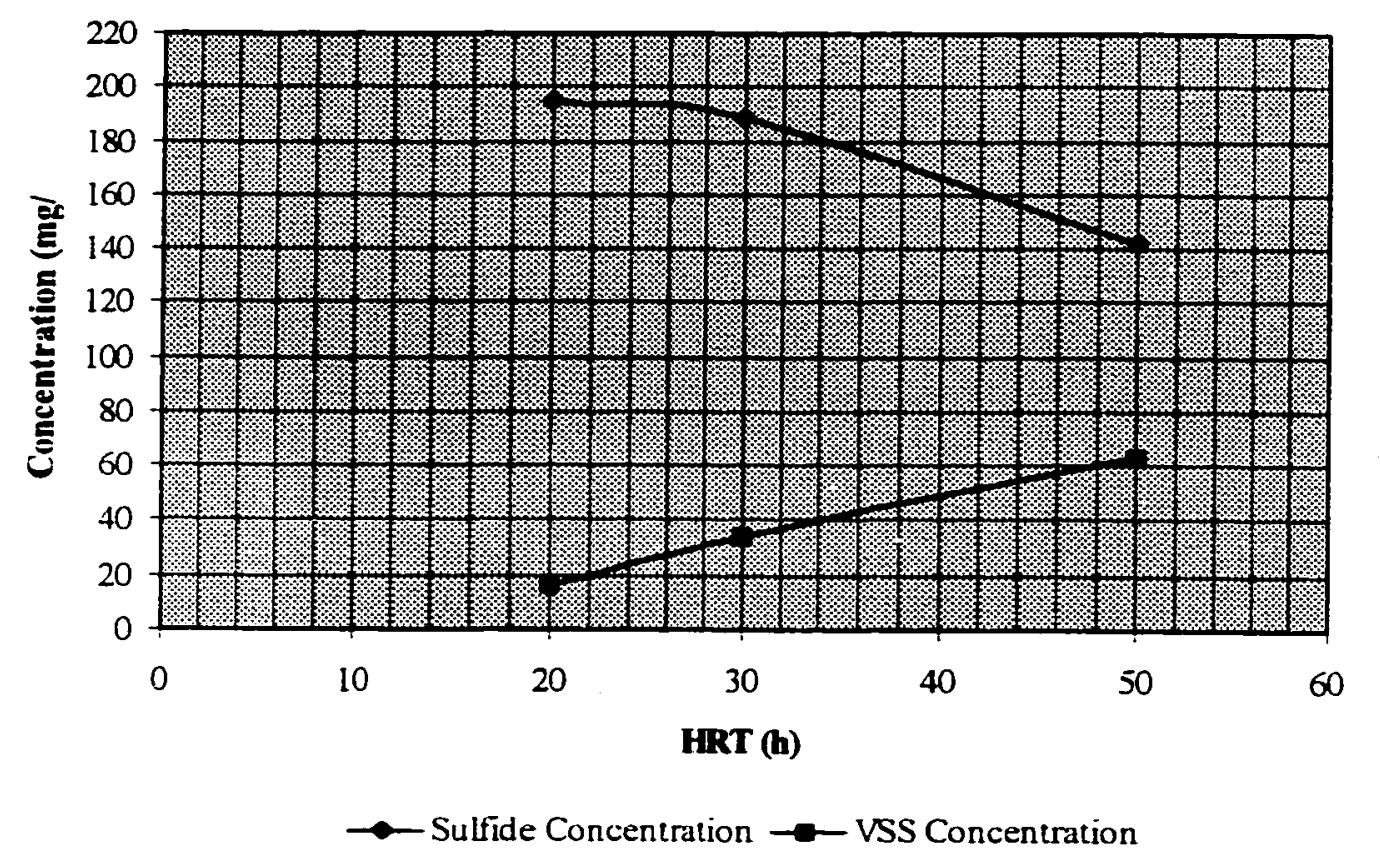

Figure 5.28 Steady State Sulfide and VSS Concentrations vs HRT. Reactor I (packed)

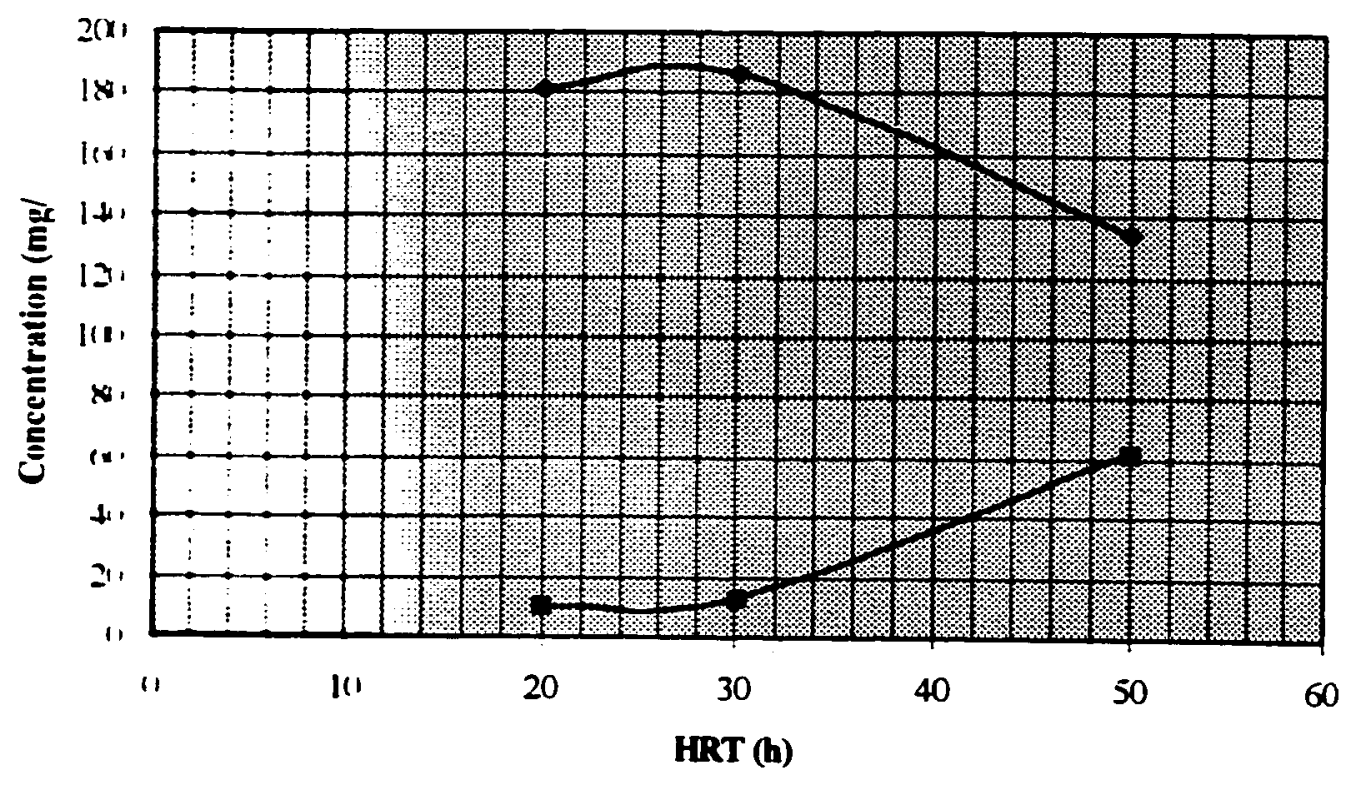

$\rightarrow$ Sulfide Concentration $\rightarrow$ VSS Concentration

Figure 5.29 Steady Siate Sulfide and VSS Concentrations vs HRT. Reactor II (non-packed) 


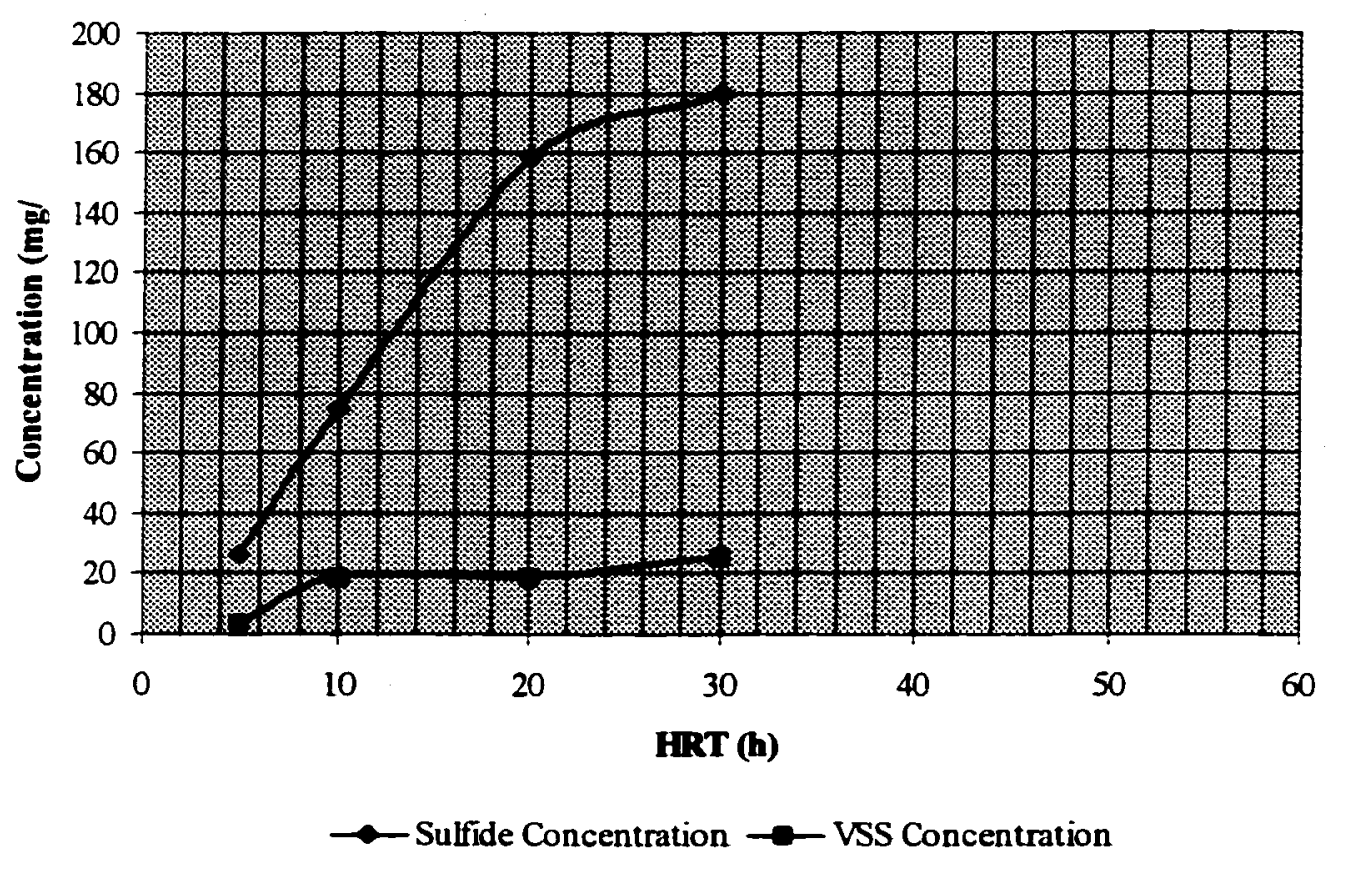

Figure 5.30 Steady State Sulfide and VSS Concentrations vs HRT.

\section{Reactor III (non-packed)}

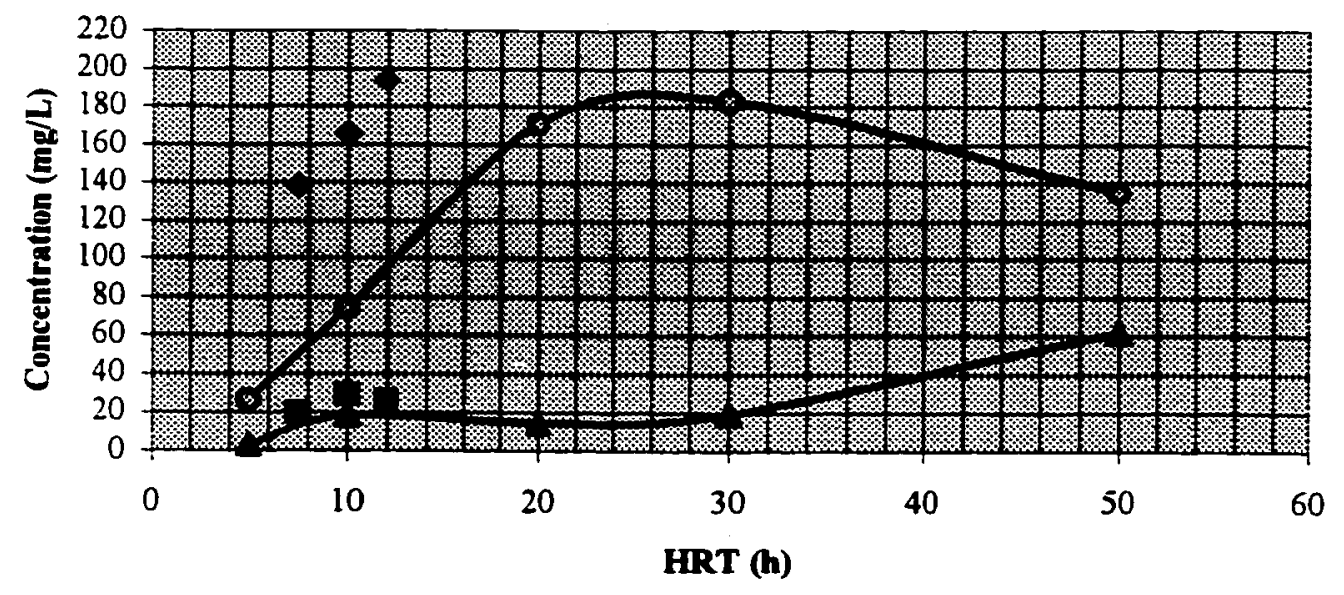

\footnotetext{
- Sulfide Concentrations Average Curve at $6 \mathrm{~kg} / \mathrm{d} / \mathrm{m} 3$

- VSS Concentrations Average Curve at $6 \mathrm{~kg} / \mathrm{d} / \mathrm{m} 3$

- Reactor II Sulfide Concentrations at $12 \mathrm{~kg} / \mathrm{d} / \mathrm{m} 3$

- Reactor II VSS Concentrations at $12 \mathrm{~kg} / \mathrm{d} / \mathrm{m} 3$
}

Figure 5.31 Reactors II and III (non-packed) Average Curves 


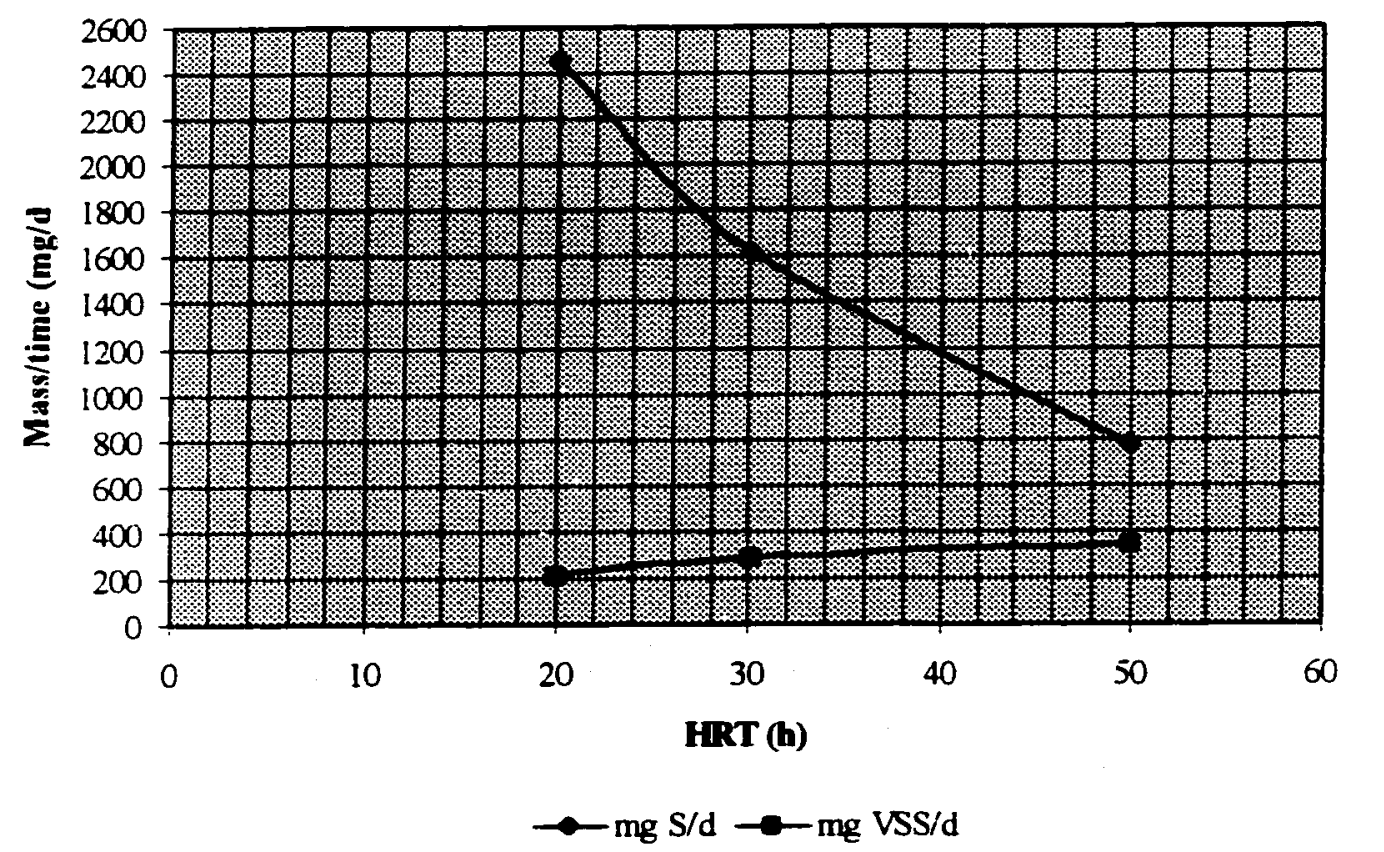

Figure 5.32 Rate of Sulfide and VSS Production vs HRT. Reactor I (packed)

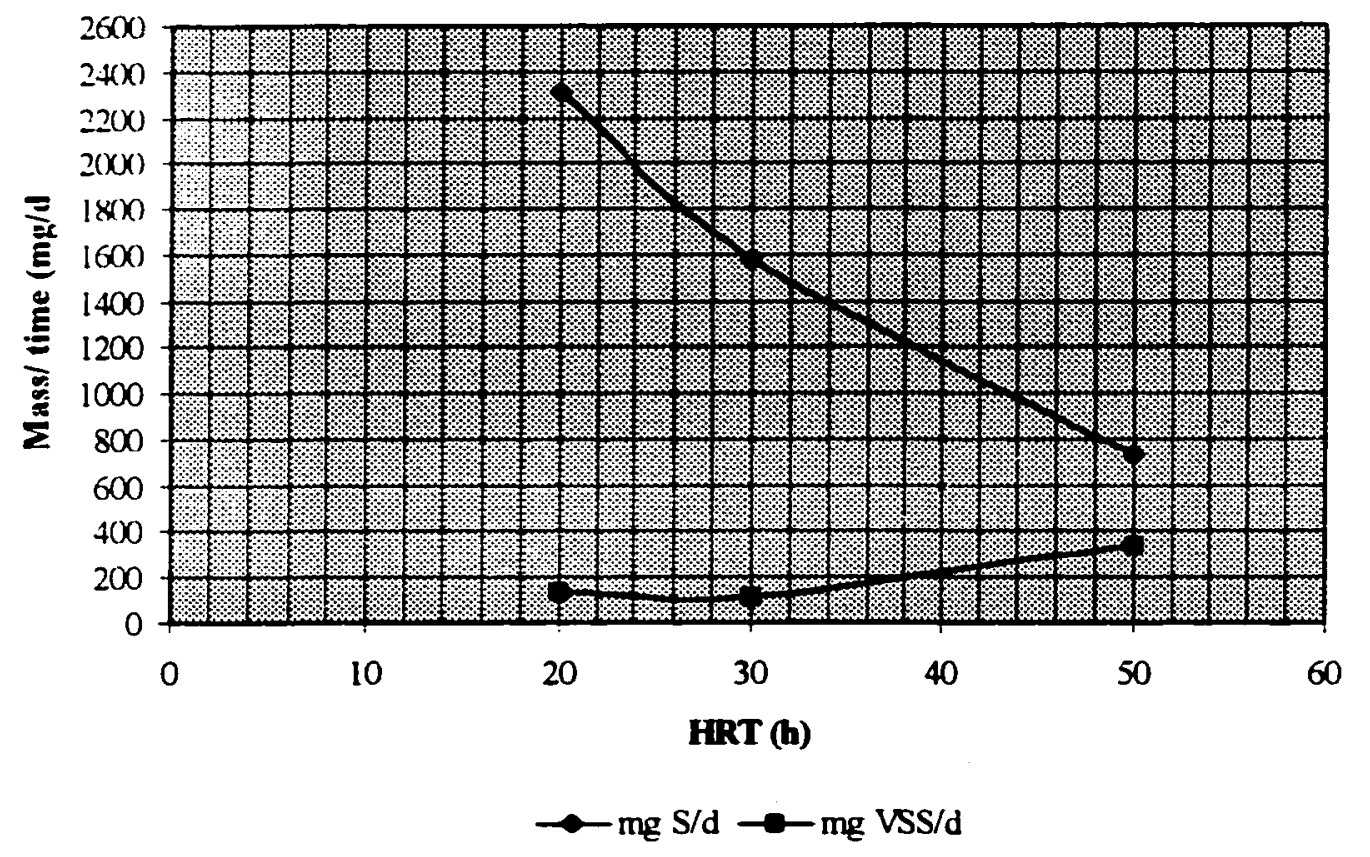

Figure 5.33 Rate of Sulfide and VSS Production vs HRT. Reactor II (non-packed) 


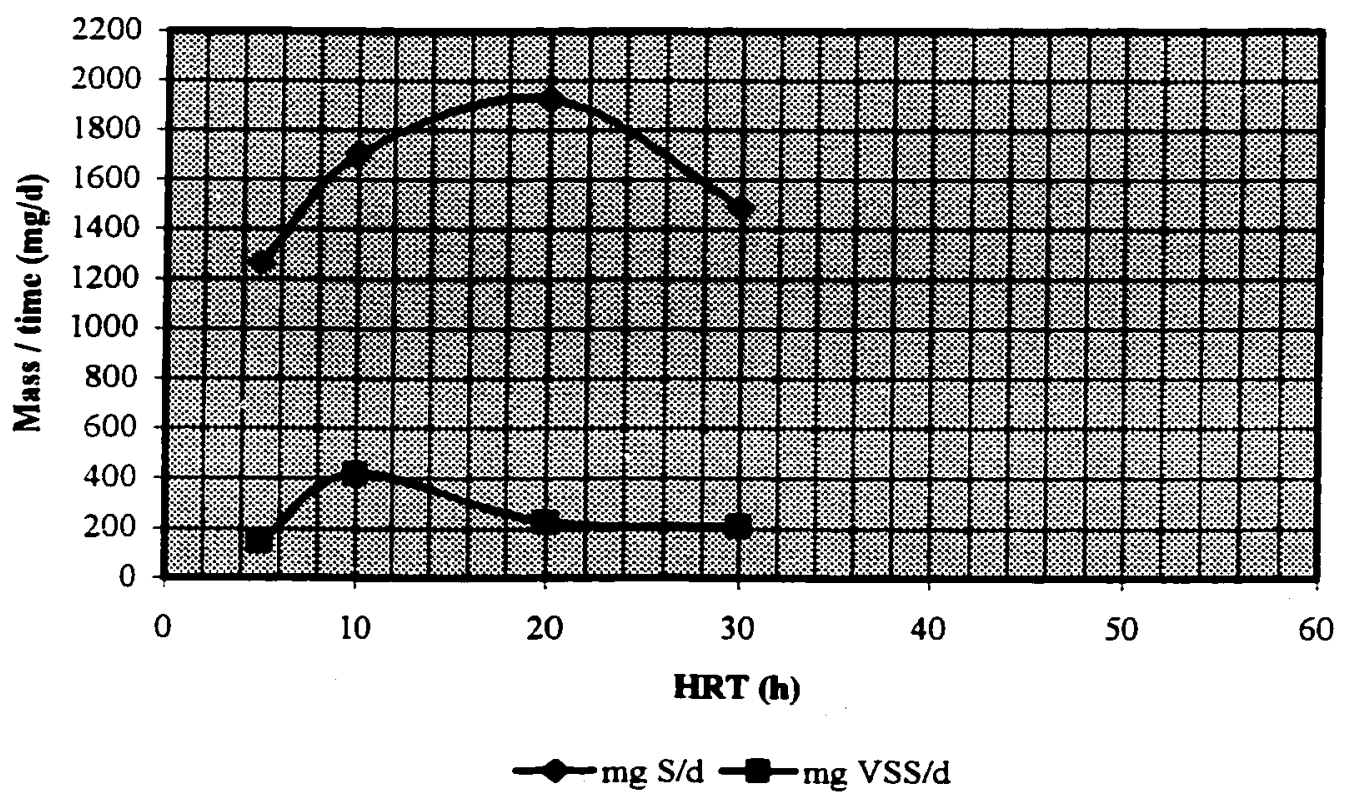

Figure 5.34 Rate of Sulfide and VSS Production vs HRT. Reactor III (non-packed)

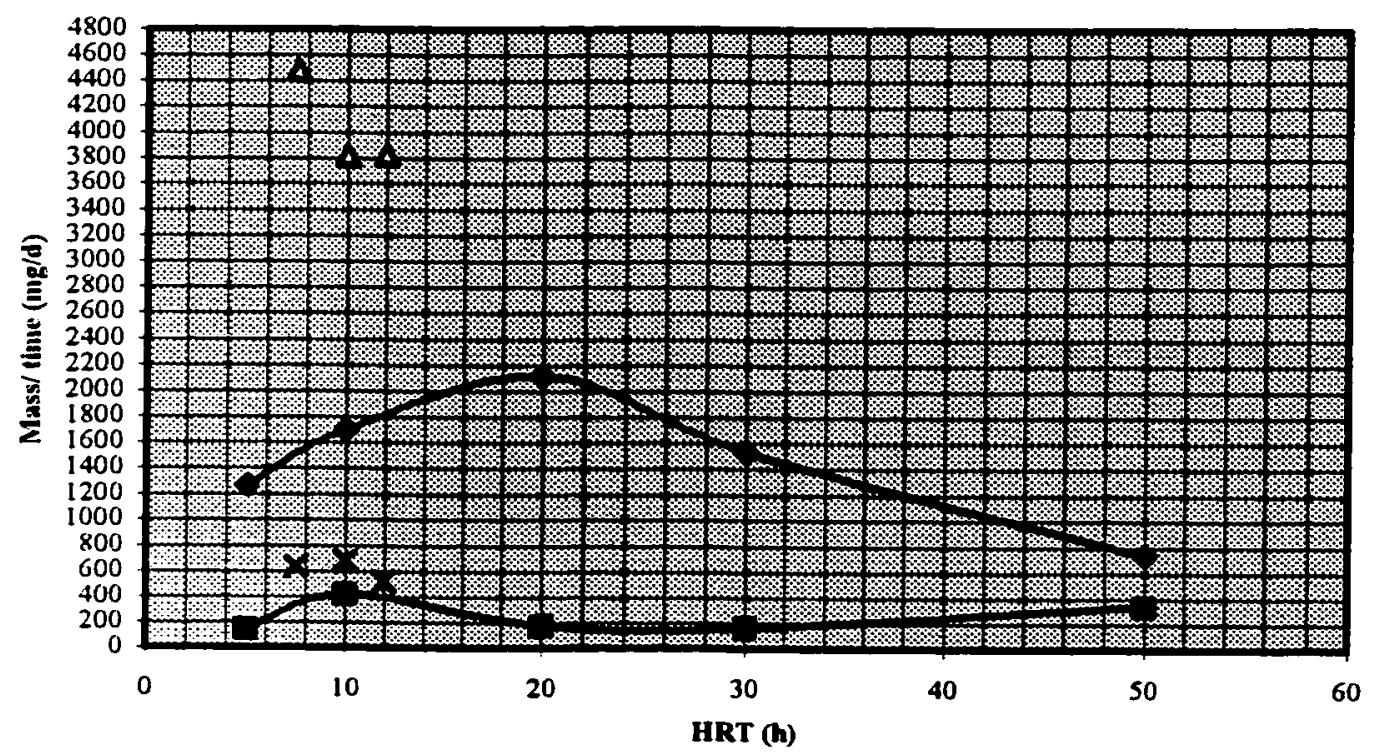

\footnotetext{
-Rate of Sulfide Production Average Curve at $6 \mathrm{~kg} / \mathrm{d} / \mathrm{m} 3$

-Rate of VSS Production Average Curve at $6 \mathrm{~kg} / \mathrm{d} / \mathrm{m}^{3}$

$\triangle$ Reactor II Rate of Sulfide Production at $12 \mathrm{~kg} / \mathrm{d} / \mathrm{m}^{3}$

$\times$ Reactor II Rate of VSS production at $12 \mathrm{~kg} / \mathrm{d} / \mathrm{m} 3$
}

Figure 5.35 Rate of Sulfide and VSS Production vs HRT. Reactors II and III (non-packed)

Average Curves 


\subsubsection{Kinetic Modeling}

\subsubsection{Kinetic Model I: Biomass Production Rate}

As indicated previously, VSS were assumed to represent the biomass in the reactor. According to Equation 4.7 developed in Chapter 4 for mass balance, the logarithm of the steady state VSS concentration for the first port, $X_{s}$, was plotted against the actual retention time, $\mathrm{V}_{\text {active }} / \mathrm{Q}$ in Figures 5.36, 5.37 and 5.38 for Reactor I (packed), Reactor II (non-packed) and Reactor III (non-packed), respectively. The specific growth rate for biomass, $\mu$, was obtained from the slope of each plot. The active volume was assumed to be up to the first port because above this port the VSS concentration was fairly uniform.

Calculations for the biomass production rate are shown in Table 5.12 and the resulting models are given below:

Reactor I: $\ln X_{s}=0.212 \frac{V}{Q}+2.32$ where, $R^{2}=1.000 \mu=0.212 h^{-1}$ and $X_{0}=10.2 \mathrm{mg} / \mathrm{L}$

Reactor II: $\ln X_{s}=0.125 \frac{V}{Q}+2.81$ where, $R^{2}=0.999 \mu=0.125 h^{-1}$ and $X_{0}=16.6 \mathrm{mg} / \mathrm{L}$. Reactor III: $\ln X_{s}=0.194 \frac{V}{Q}+2.39$ where, $R^{2}=0.988 \mu=0.194 h^{-1}$ and $X_{0}=10.9 \mathrm{mg} / \mathrm{L}$.

The following equation for rate of substrate utilization was used to obtain the sulfide production rate from the biomass concentrations obtained above: 


$$
\begin{aligned}
& \frac{\mathrm{dL}}{\mathrm{dt}}=\frac{1}{\mathrm{Y}} \frac{\mathrm{d} X_{s}}{\mathrm{dt}}=\frac{1}{\mathrm{Y}} \mu \mathrm{X}_{\mathrm{s}}=\frac{\mu}{\mathrm{Y}} \mathrm{X}_{\mathrm{s}}=\mathrm{k} \mathrm{X}_{\mathrm{s}} \\
& \frac{\mathrm{d} C_{\mathrm{s}}}{\mathrm{dt}}=\left(\frac{1}{2.6} \frac{\mathrm{mg} / \mathrm{L} \text { sulfide }}{\mathrm{mg} / \mathrm{L} \text { lactate }}\right) \frac{\mathrm{dL}}{\mathrm{dt}}=\frac{\mathrm{k}}{2.6} \mathrm{X}_{\mathrm{s}}
\end{aligned}
$$

Where,

$\mathrm{dL} / \mathrm{dt}=$ lactate consumption rate under steady state conditions $[\mathrm{mg} / \mathrm{h} / \mathrm{L}]$

$\mathrm{dX}_{\mathrm{S}} / \mathrm{dt}=$ biomass production rate under steady state conditions $[\mathrm{mg} / \mathrm{h} / \mathrm{L}]$

$\mathrm{Y}=$ yield coefficient $=\frac{\text { mass of VSS produced } / \mathrm{d}}{\text { mass of lactate consumed } / \mathrm{d}}=\frac{\text { mass of VSS produced } / \mathrm{d}}{2.6 \mathrm{mass} \text { of sulfide produced } / \mathrm{d}}$

$\mu=$ specific growth rate $\left[\mathrm{h}^{-1}\right]$

$\mathrm{k}=\mu / \mathrm{Y}=$ substrate utilization rate constant $\left[\mathrm{h}^{-1}\right]$

$\mathrm{X}_{\mathrm{s}}=$ steady state biomass concentration for the first port $[\mathrm{mg} / \mathrm{L}]$

$\mathrm{dC}_{\mathrm{S}} / \mathrm{dt}=$ sulfide production rate under steady state conditions $[\mathrm{mg} / \mathrm{h} / \mathrm{L}]$

Calculations for $\mathrm{k}$ and the sulfide production rate are also shown in Table 5.12. 


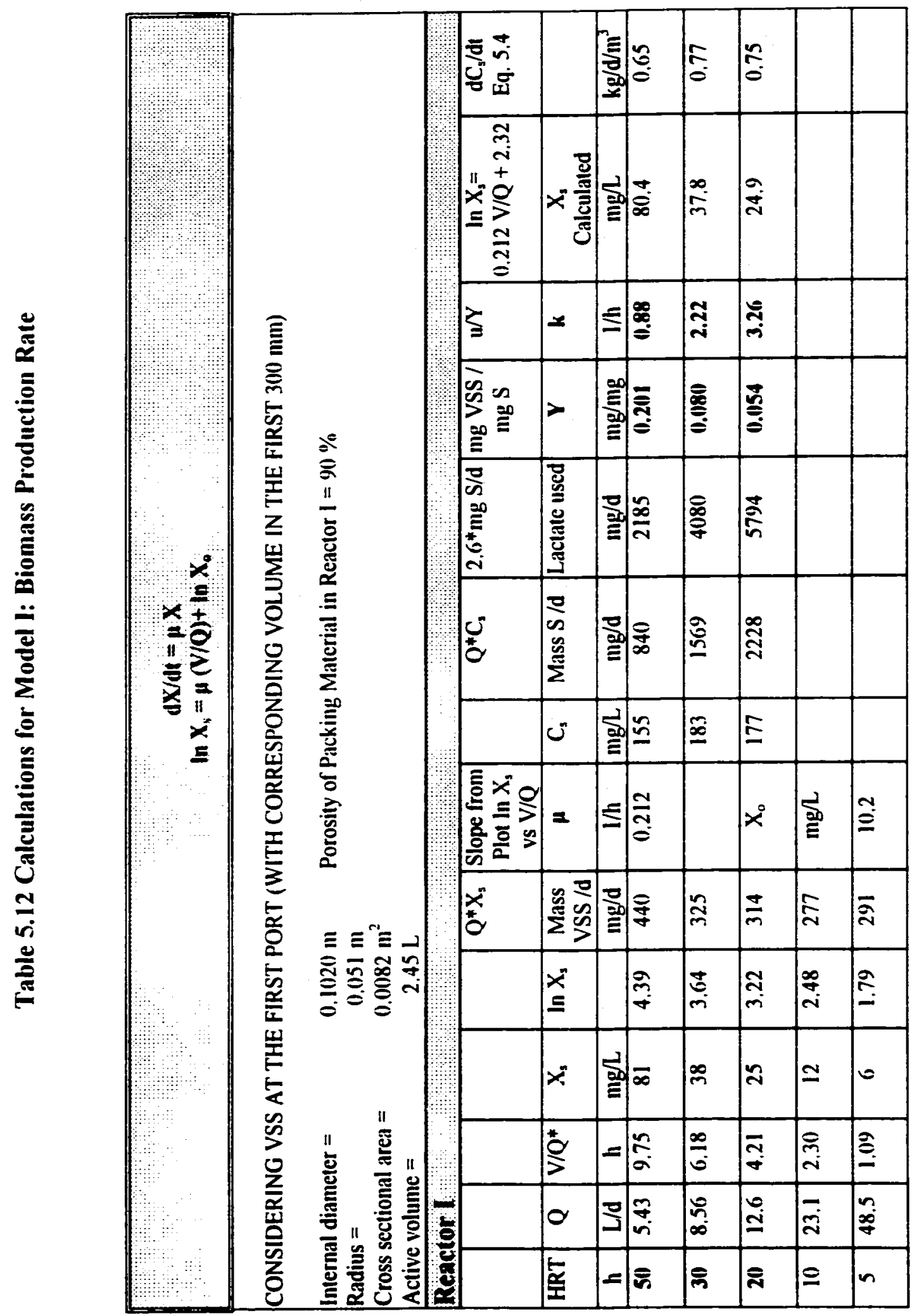

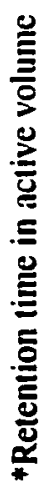




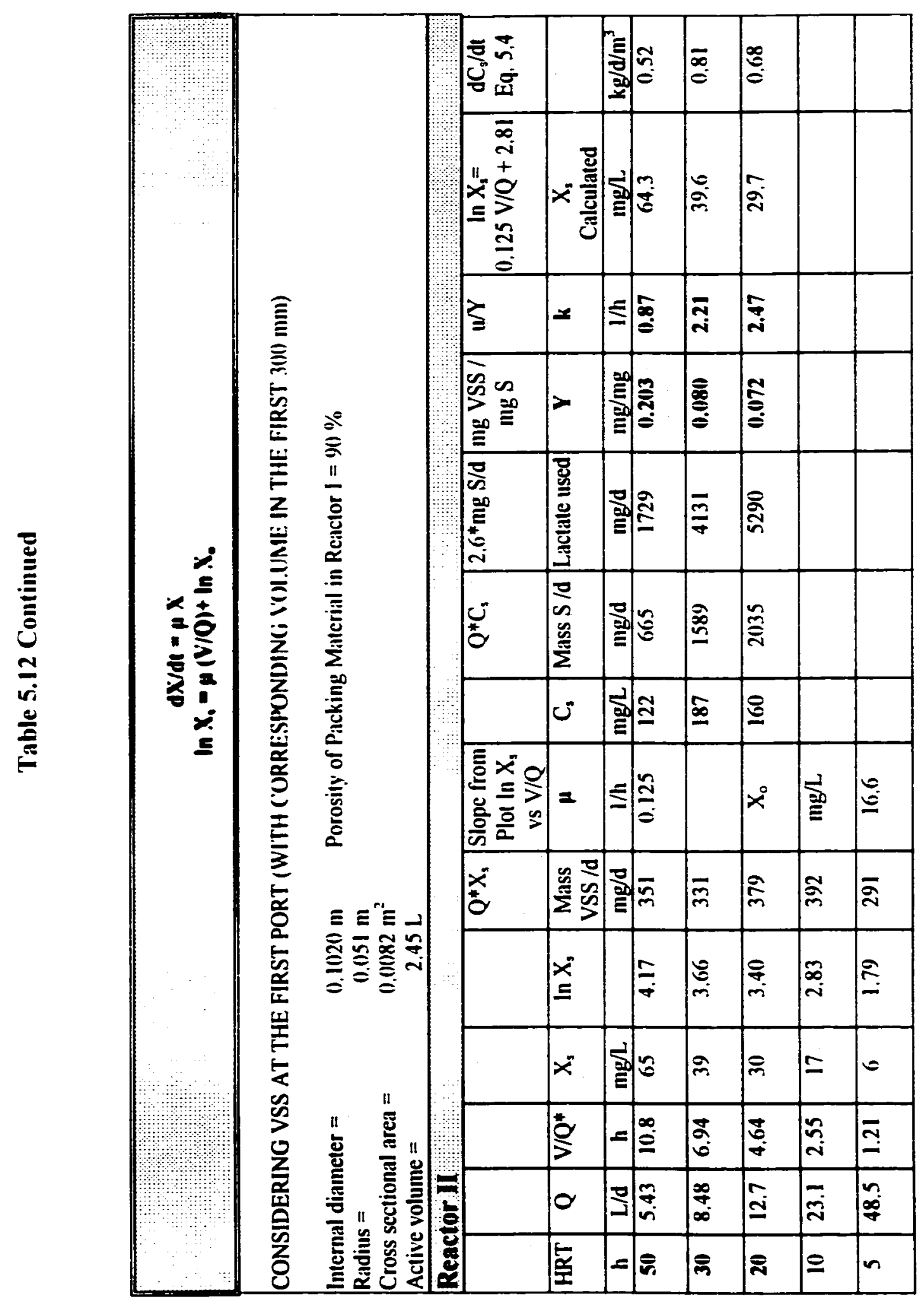

兰 


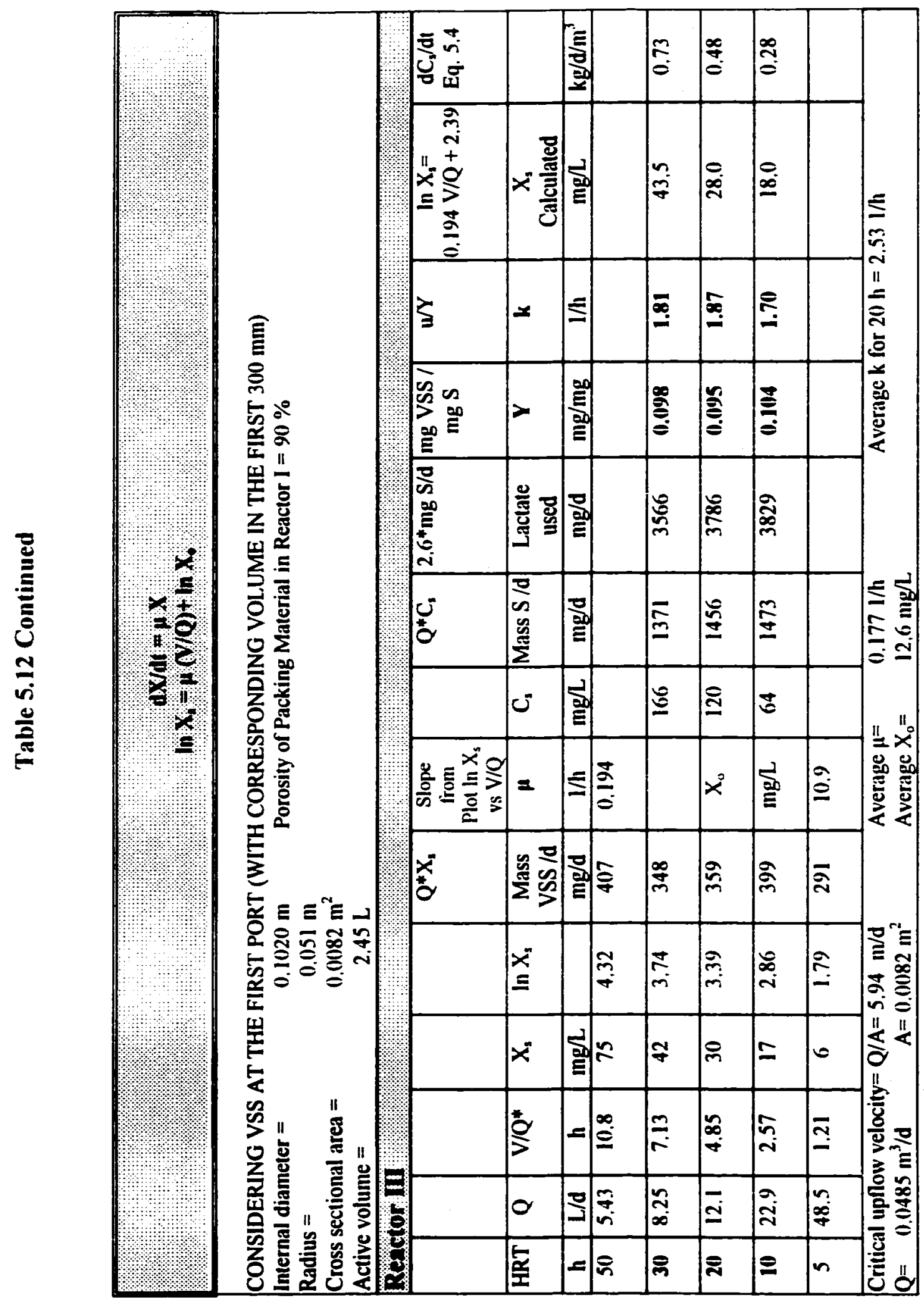

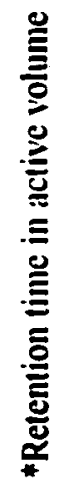




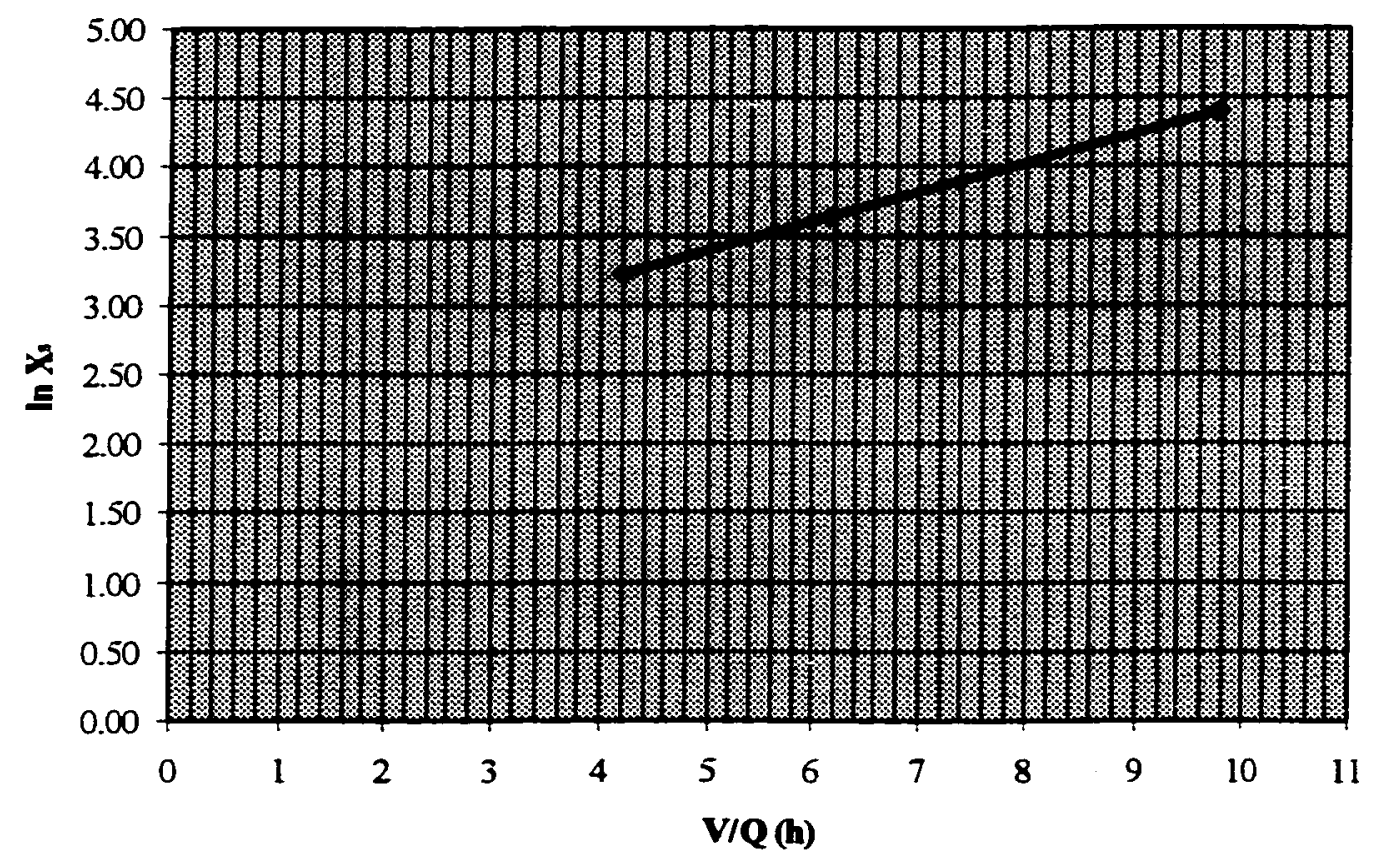

Figure 5.36 Model I: Biomass Production Rate. Reactor I (packed)

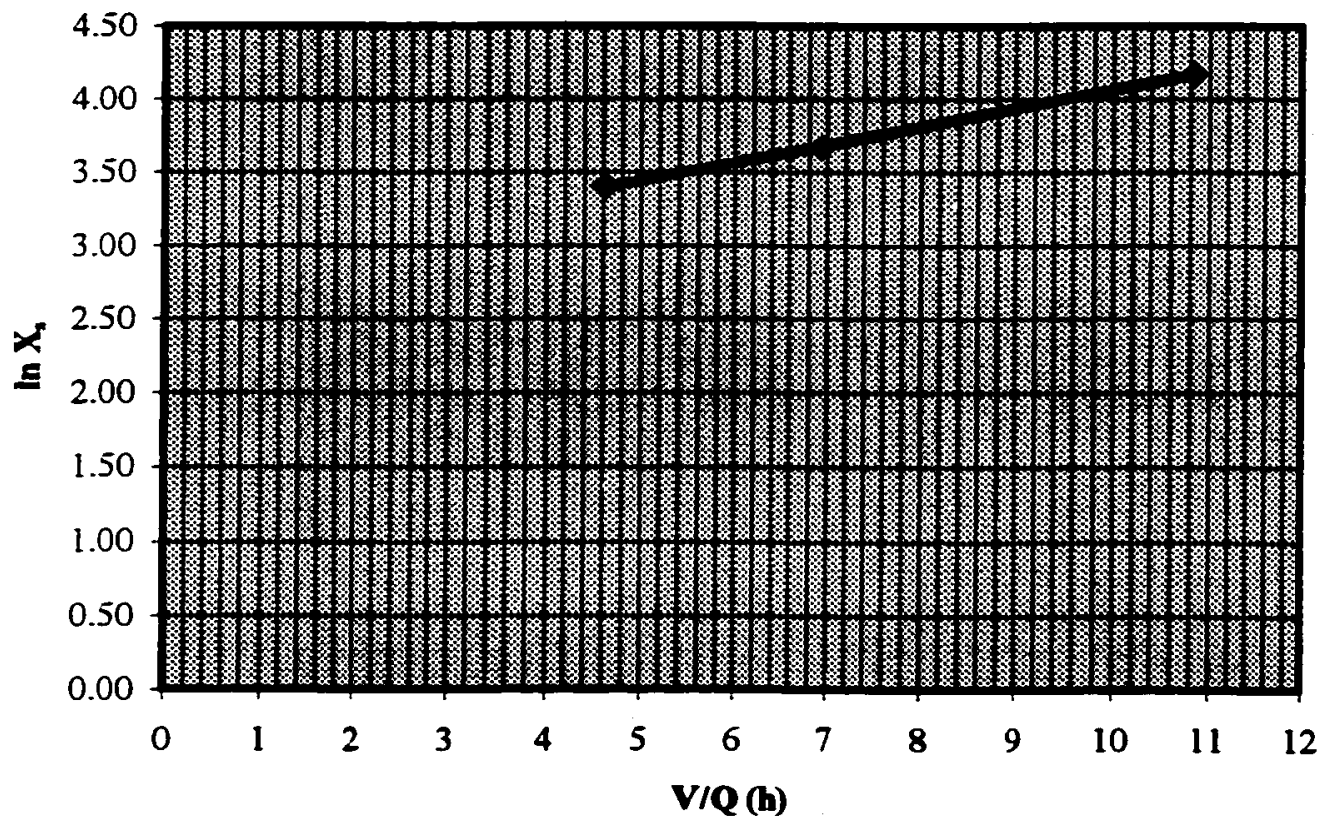

Figure 5.37 Model I: Biomass Production Rate. Reactor II (non-packed) 


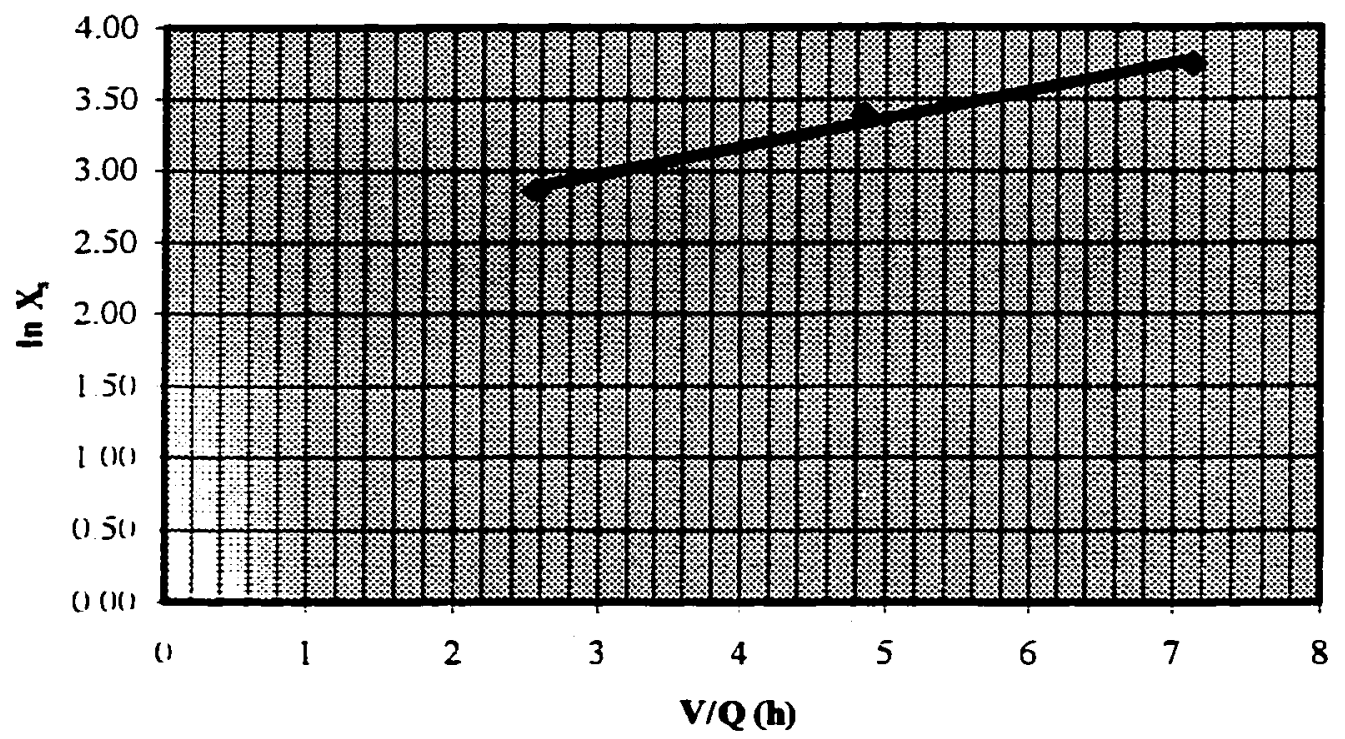

Figure 5.38 Model I: Biomass Production Rate. Reactor III (non-packed)

\subsubsection{Kinetic Mlodel II: Sulfide Production Rate}

According to Equation 4.9 developed in Chapter 4 for mass balance, the logarithm of the steady state sulfide concentration for the first port, $C_{s}$, was plotted against the actual retention time, $V_{\text {active }} / Q$ in Figures 5.39, 5.40 and 5.41 for Reactor I (packed), Reactor II (non-packed) and Reactor III (non-packed), respectively. The rate constant, K, was obtained from the slope of each plot. The active volume was assumed to be up to the first port because above this port the VSS concentration was fairly uniform.

The calculations for sulfide production rate are shown in Table 5.13 and the resulting models are given below: 
Reactor I: $\quad \ln C_{s}=-0.0274 \frac{V}{Q}+5.33$ where, $R^{2}=0.733 \quad K=-0.0274 h^{-1}$ and $\mathrm{C}_{0}=206 \mathrm{mg} / \mathrm{L}$.

Reactor II: $\quad$ In $C_{s}=-0.0504 \frac{V}{Q}+5.42$ where, $R^{2}=0.538 \quad K=-0.0504 h^{-1}$ and $\mathrm{C}_{\mathrm{o}}=226 \mathrm{mg} / \mathrm{L}$.

Reactor III: $\ln \mathrm{C}_{\mathrm{s}}=0.2080 \frac{\mathrm{V}}{\mathrm{Q}}+3.68$ where, $\mathrm{R}^{2}=0.968 \quad \mathrm{~K}=0.208 \mathrm{~h}^{-1}$ and $\mathrm{C}_{\mathrm{o}}=39.6 \mathrm{mg} / \mathrm{L}$.

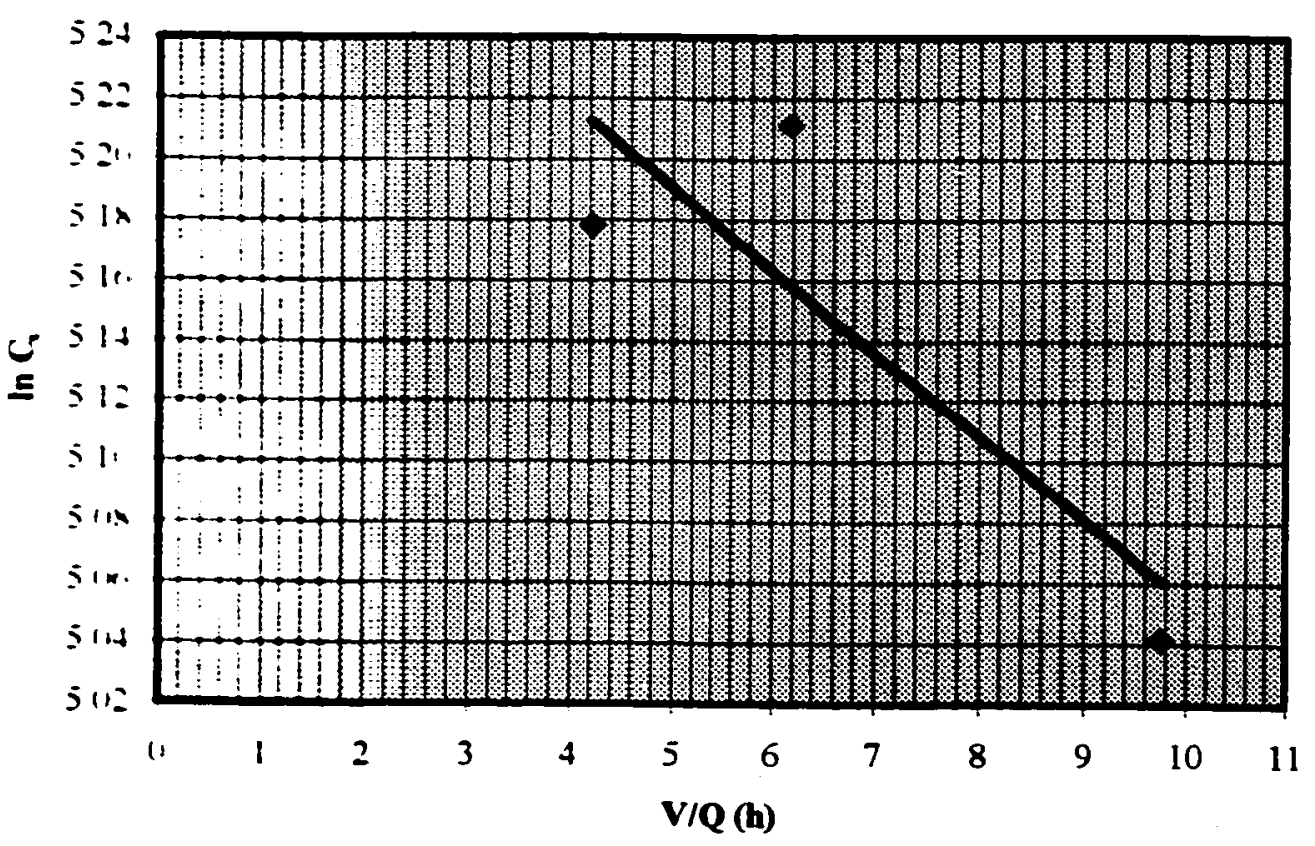

Figure 5.39 .Model II: Sulfide Production Rate. Reactor I (packed) 


\begin{tabular}{|c|c|c|c|c|c|c|c|}
\hline \multicolumn{3}{|c|}{$\begin{aligned} 4+4 \\
4\end{aligned}$} & \multicolumn{5}{|c|}{ 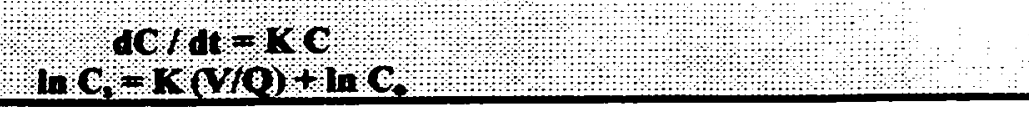 } \\
\hline \multicolumn{8}{|c|}{$\begin{array}{ll}\text { CONSIDERING VSS AT THE FIRST PORT (WITH CORRESPONDING VOLUME IN THE FIRST } \\
\text { 300 mm) } & 0.1020 \mathrm{~m} \quad \text { Porosity of Packing Material in Reactor I = 90\% } \\
\text { Internal diameter = } & 0.051 \mathrm{~m} \\
\text { Radius = } & 0.0082 \mathrm{~m}^{2} \\
\text { Cross sectional area }= & 2.45 \mathrm{~L} \\
\text { Active volume = }\end{array}$} \\
\hline \multicolumn{8}{|c|}{ Reactor I } \\
\hline & & $\begin{array}{c}\text { up to lst } \\
\text { port }\end{array}$ & \begin{tabular}{|c|} 
up to lst \\
port
\end{tabular} & & \begin{tabular}{|c|} 
Slope from \\
Plot $\ln C_{s}$ vs V/Q
\end{tabular} & $\begin{array}{c}\ln \mathrm{Cs}_{\mathrm{s}} \\
-0.0274 \mathrm{~V} / \mathrm{Q}+ \\
5.33 \\
\end{array}$ & $Q^{*} C_{s \text { calc. }}$ \\
\hline HRT & Q & $\mathrm{V} / \mathrm{Q}^{*}$ & $C_{s}$ & $\ln C_{3}$ & $\mathbf{K}$ & $\mathrm{C}_{\text {s }}$ calculated & Mass S'd \\
\hline $\mathrm{h}$ & $\mathrm{L} / \mathrm{d}$ & h & $\mathrm{mg} / \mathrm{L}$ & & $1 / \mathrm{h}$ & $\mathrm{mg} / \mathrm{L}$ & $\mathrm{mg} / \mathrm{d}$ \\
\hline 50 & 5.43 & 9.75 & 155 & 5.04 & -0.0274 & 158 & 858 \\
\hline 30 & 8.56 & 6.18 & 183 & 5.21 & & 174 & 1492 \\
\hline 20 & 12.6 & 4.21 & 177 & 5.18 & $\mathrm{C}_{0}$ & 184 & 2311 \\
\hline 10 & 23.1 & 2.30 & & & $\mathrm{mg} / \mathrm{L}$ & & \\
\hline 5 & 48.5 & 1.09 & & & 206 & & \\
\hline \multicolumn{8}{|c|}{ Reactor I } \\
\hline & & $\begin{array}{l}\text { up to Ist } \\
\text { port }\end{array}$ & $\begin{array}{c}\text { up to lst } \\
\text { port }\end{array}$ & & \begin{tabular}{|c|} 
Slope from \\
Plot $\ln C_{s}$ vs $V / Q$
\end{tabular} & $\begin{array}{c}\ln \mathrm{Cs}_{5}= \\
-0.0504 \mathrm{~V} / \mathrm{Q}+ \\
5.42 \\
\end{array}$ & $Q^{*} C_{\text {s calc. }}$ \\
\hline HRT & $\mathrm{Q}$ & $\mathrm{V} / \mathrm{Q}^{*}$ & $\mathrm{C}_{\mathrm{s}}$ & $\ln C_{3}$ & $\mathbf{K}$ & $\mathrm{C}_{5}$ calculated & Mass S/d \\
\hline $\mathrm{h}$ & L/d & $\mathrm{h}$ & $\mathrm{mg} / \mathrm{L}$ & & $1 / \mathrm{h}$ & $\mathrm{mg} / \mathrm{L}$ & $\mathrm{mg} / \mathrm{d}$ \\
\hline 50 & 5.43 & 10.8 & 122 & 4.81 & -0.0504 & 131 & 710 \\
\hline 30 & 8.48 & 6.94 & 187 & 5.23 & & 159 & 1349 \\
\hline 20 & 12.7 & 4.64 & 160 & 5.08 & $\mathrm{C}_{\mathrm{o}}$ & 179 & 2269 \\
\hline 10 & 23.1 & 2.55 & & & $\mathbf{m g} / \mathbf{L}$ & & \\
\hline 5 & 48.5 & 1.21 & & & 226 & & \\
\hline \multicolumn{8}{|c|}{ Reactor II } \\
\hline & & $\begin{array}{l}\text { up to lst } \\
\text { port }\end{array}$ & \begin{tabular}{|c|} 
up to lst \\
port
\end{tabular} & & $\begin{array}{c}\text { Slope from } \\
\text { Plot } \ln C_{s} \text { vs V/Q }\end{array}$ & $\begin{array}{c}\ln \mathrm{Cs}_{\mathrm{s}} \\
-0.0208 \mathrm{~V} / \mathrm{Q}+ \\
3.68 \\
\end{array}$ & $Q^{*} C_{\text {s calc }}$ \\
\hline HRT & $\mathbf{Q}$ & $\mathrm{V} / \mathrm{Q}^{*}$ & $\mathrm{C}_{\mathrm{s}}$ & $\ln C_{s}$ & $\mathbf{K}$ & $\mathrm{C}_{\mathrm{s}}$ calculated & Mass S/d \\
\hline $\mathrm{h}$ & $\mathrm{L} / \mathrm{d}$ & h & $\mathrm{mg} / \mathrm{L}$ & & $1 / \mathrm{h}$ & $\mathrm{mg} / \mathrm{L}$ & $\mathrm{mg} / \mathrm{d}$ \\
\hline 50 & 5.43 & 10.8 & & & 0.2080 & & \\
\hline 30 & 8.25 & 7.13 & 166 & 5.11 & & 175 & 1442 \\
\hline 20 & 12.1 & 4.85 & 120 & 4.79 & $\mathrm{C}_{0}$ & 109 & 1319 \\
\hline 10 & 22.9 & 2.57 & 64 & 4.17 & $\mathrm{mg} / \mathrm{L}$ & 68 & 1548 \\
\hline 5 & 48.5 & 1.21 & 4 & 1.39 & 39.6 & & \\
\hline \multicolumn{8}{|c|}{ average $K=$} \\
\hline \multicolumn{8}{|c|}{ average $\mathrm{Co}=$} \\
\hline
\end{tabular}

*Retention time in active volume 


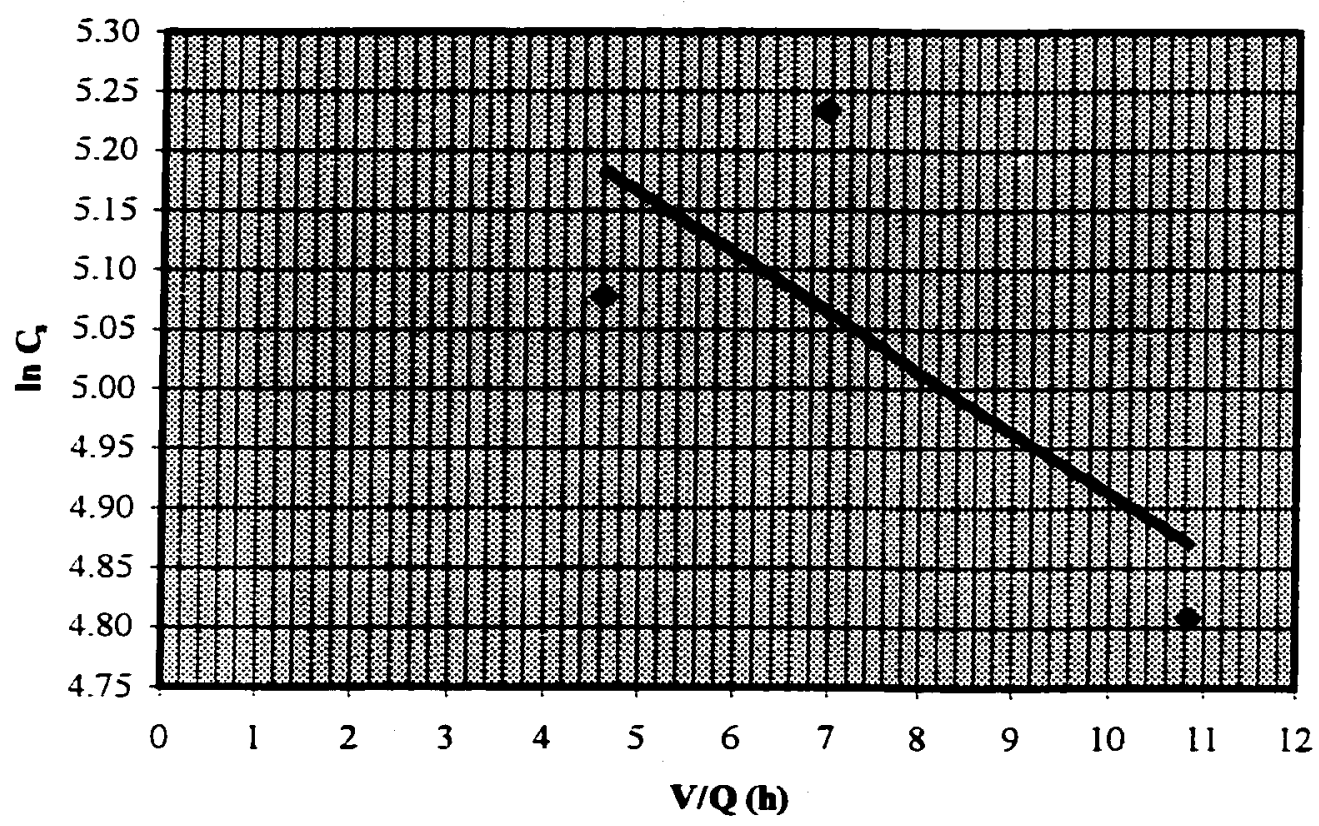

Figure 5.40 Model II: Sulfide Production Rate. Reactor II (non-packed)

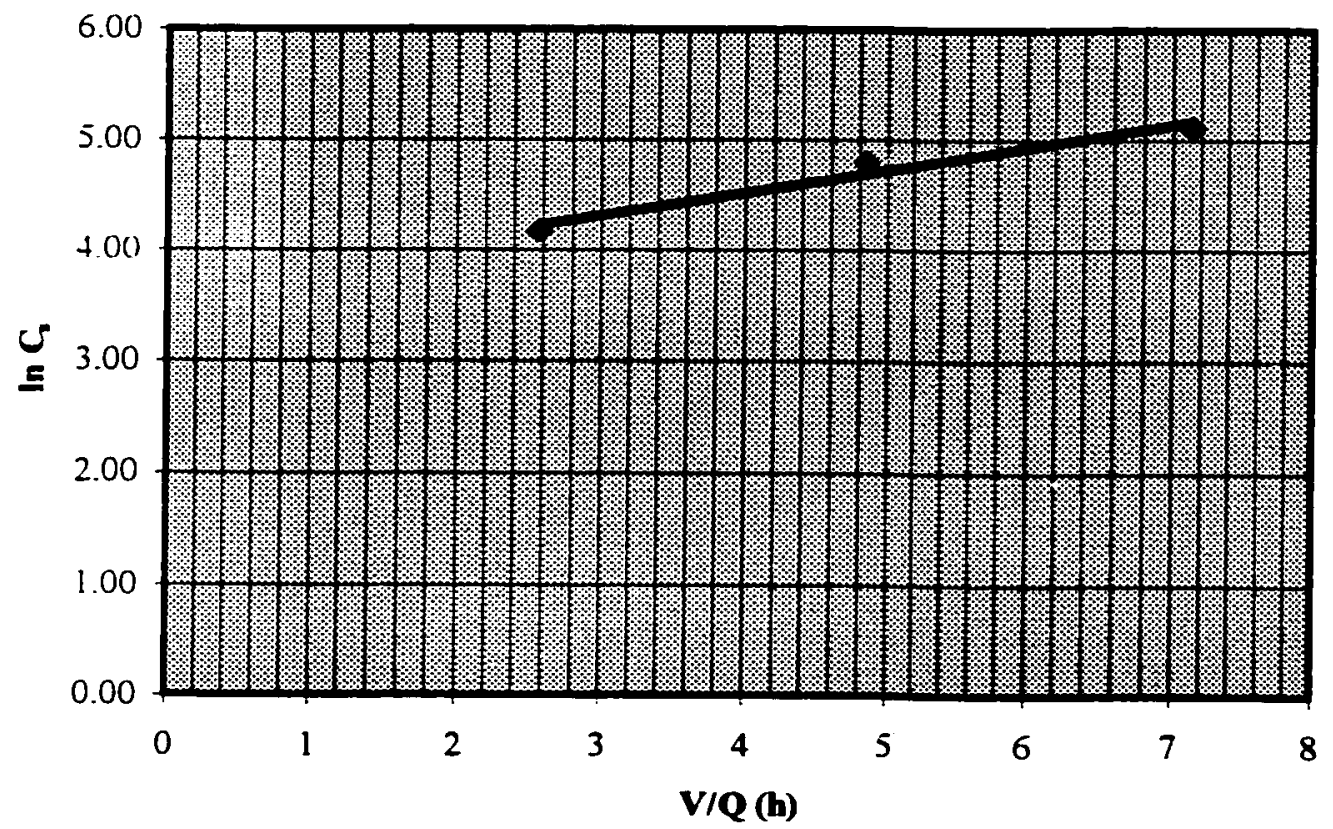

Figure 5.41 Model II: Sulfide Production Rate. Reactor III (non-packed) 


\subsubsection{Kinetic Model II: Sulinde and Biomass Concentrations}

According to Equation 4.11 developed in Chapter 4 for mass balance, the logarithm of the steady state sulfide concentration for the first port, $C_{s}$, was plotted against $X_{s} V_{\text {active }} / Q$, where $X_{s}$ represents the steady state VSS concentration for the first port, as shown in Figures 5.42, 5.43 and 5.44 for Reactor I (packed), Reactor II (non-packed) and Reactor III (non-packed), respectively. The rate constant, $K^{\prime}$, was obtained from the slope of each plot. The active volume was assumed to be up to the first port because above this port the VSS concentration was fairly uniform.

The calculations for sulfide production rate are shown in Table 5.14 and the resulting models are given below

Reactor I: In $C_{0}=-10002 X_{s} \frac{V}{Q}+5.23$ where, $R^{2}=0.873 \quad K^{\prime}=-0.0002 h^{-1}$ and $\mathrm{C}_{\mathrm{o}}=187 \mathrm{mg} / \mathrm{L}$

Reactor Il In C. : fl0006 $X_{s} \frac{V}{Q}+5.26$ where, $R^{2}=0.683 \quad K^{\prime}=-0.0006 h^{-1}$ and $\mathrm{C}_{\mathrm{o}}=192 \mathrm{mg} / \mathrm{L}$

Reactor III In $C_{1}=110035 X_{s} \frac{V}{Q}+4.11$ where, $R^{2}=0.906 \quad K^{\prime}=0.0035 h^{-1}$ and $C_{0}=60.9 \mathrm{mg} /$ 
Table 5.14 Calculations for Model III: Sulfide and Biomass Concentrations

\begin{tabular}{|c|c|c|c|c|c|c|c|c|}
\hline \multicolumn{9}{|c|}{ (1) } \\
\hline \multicolumn{9}{|c|}{$\begin{array}{lll}\text { CONSIDERING VSS AT THE FIRST PORT (WITH CORRESPONDING VOLUME IN THE } \\
\text { FIRST 300 mm) } & & \\
\text { Internal diameter }= & 0.1020 \mathrm{~m} & \text { Porosity of Packing Material in Reactor I = 90\% } \\
\text { Radius = } & 0.051 \mathrm{~m} & \\
\text { Cross sectional area }= & 0.0082 \mathrm{~m}^{2} & \\
\text { Active volume = } & 2.45 \mathrm{~L} & \end{array}$} \\
\hline \multicolumn{9}{|c|}{ Reactor I } \\
\hline & & up to 1 & port & & up to & st port & $\mathrm{Q}^{*} \mathrm{C}_{\mathrm{s}}$ & $\begin{array}{c}\text { Slope from } \\
\text { Plot In } C_{s} \text { vs } \\
X_{s} *(V / Q) \\
\end{array}$ \\
\hline HRT & $\mathbf{Q}$ & $\mathrm{V} / \mathrm{Q}^{*}$ & $X_{s}$ & $\mathrm{X}_{\mathrm{s}}^{*} \mathrm{~V} / \mathrm{Q}$ & $\mathrm{C}_{\mathrm{s}}$ & $\ln C_{3}$ & Mass S /d & $\mathbf{K}^{\prime}$ \\
\hline $\mathrm{h}$ & L/d & $\mathbf{h}$ & $\mathbf{m g} / \mathbf{L}$ & & $\mathrm{mg} / \mathrm{L}$ & & $\mathbf{m g} / \mathbf{d}$ & $\mathrm{L} /\left(\mathbf{m g} \mathbf{g}^{*} \mathbf{h}\right)$ \\
\hline 50 & 5.43 & 9.75 & 81 & 878 & 155 & 5.04 & 440 & -0.0002 \\
\hline 30 & 8.56 & 6.18 & 38 & 261 & 183 & 5.21 & 325 & \\
\hline 20 & 12.6 & 4.21 & 25 & 117 & 177 & 5.18 & 314 & $\mathrm{C}_{\mathrm{o}}$ \\
\hline 10 & 23.1 & 2.30 & 12 & 30.6 & & & 277 & $\mathrm{mg} / \mathrm{L}$ \\
\hline 5 & 48.5 & 1.09 & 6 & 7.27 & & & 291 & 187 \\
\hline \multicolumn{9}{|c|}{ Reactor I } \\
\hline & & \multicolumn{2}{|c|}{ up to lst port } & & \multicolumn{2}{|c|}{ up to lst port } & $\mathrm{Q}^{*} \mathrm{C}_{3}$ & $\begin{array}{l}\text { Slope from } \\
\text { Plot In } C_{s} \text { vs } \\
X_{\mathrm{s}}^{*}(V / Q) \\
\end{array}$ \\
\hline HRT & $\mathbf{Q}$ & $\mathrm{V} / \mathrm{Q}^{*}$ & $\overline{X_{s}}$ & $\mathrm{X}_{\mathrm{s}} * \mathrm{~V} / \mathrm{Q}$ & $\overline{C_{s}}$ & $\ln C_{s}$ & Mass S/d & $\mathbf{K}^{\prime}$ \\
\hline $\mathrm{h}$ & $L / d$ & h & $\mathrm{mg} / \mathrm{L}$ & & $\mathrm{mg} / \mathrm{L}$ & & $\mathrm{mg} / \mathrm{d}$ & $\mathrm{L} /\left(\mathrm{mg}^{*} \mathrm{~h}\right)$ \\
\hline 50 & 5.43 & 10.8 & 65 & 700 & 122 & 4.81 & 351 & -0.0006 \\
\hline 30 & 8.48 & 6.94 & 39 & 271 & 187 & 5.23 & 331 & \\
\hline 20 & 12.7 & 4.64 & 30 & 139 & 160 & 5.08 & 379 & $\mathrm{C}_{0}$ \\
\hline 10 & 23.1 & 2.55 & 17 & 43.4 & & & & $\mathrm{mg} / \mathrm{L}$ \\
\hline 5 & 48.5 & 1.21 & 6 & 7.27 & & & & 192 \\
\hline \multicolumn{9}{|c|}{ Reactor III } \\
\hline & & \multicolumn{2}{|c|}{ up to lst port } & & \multicolumn{2}{|c|}{ up to lst port } & $\overline{Q^{*} C_{s}}$ & $\begin{array}{c}\text { Slope from } \\
\text { Plot } \ln C_{s} \text { vs } \\
X_{s}^{*}(V / Q) \\
\end{array}$ \\
\hline HRT & $\mathbf{Q}$ & $\mathrm{V} / \mathrm{Q}^{*}$ & $X_{s}$ & $\mathrm{X}_{\mathrm{s}} * \mathrm{~V} / \mathrm{Q}$ & $\mathrm{C}_{3}$ & $\ln C_{3}$ & Mass S /d & $\mathbf{K}^{\prime}$ \\
\hline $\mathrm{h}$ & $\mathrm{L} / \mathrm{d}$ & $\mathbf{h}$ & $\mathrm{mg} / \mathrm{L}$ & & $\mathrm{mg} / \mathrm{L}$ & & $\mathrm{mg} / \mathrm{d}$ & $\mathrm{L} /\left(\mathbf{m g} \mathbf{g}^{*} \mathrm{~h}\right)$ \\
\hline 50 & 5.43 & 10.8 & 75 & 813 & & & & 0.0035 \\
\hline 30 & 8.25 & 7.13 & 42 & 301 & 166 & 5.11 & 348 & \\
\hline 20 & 12.1 & 4.85 & 30 & 143 & 120 & 4.79 & 359 & $\mathrm{C}_{\mathrm{o}}$ \\
\hline 10 & 22.9 & 2.57 & 17 & 44.9 & 64 & 4.17 & 399 & $\mathbf{m g} / \mathbf{L}$ \\
\hline 5 & 48.5 & 1.21 & 6 & 7.28 & 4 & 1.39 & 291 & 60.9 \\
\hline \multicolumn{6}{|c|}{ Critical upflow velocity $=Q / A=5.93 \mathrm{~m} / \mathrm{d}$} & $\mathrm{Q}=\mathbf{0}$. & $m^{3} / d$ & $0.0082 \mathrm{~m}^{2}$ \\
\hline
\end{tabular}

*Retention time in active volume 


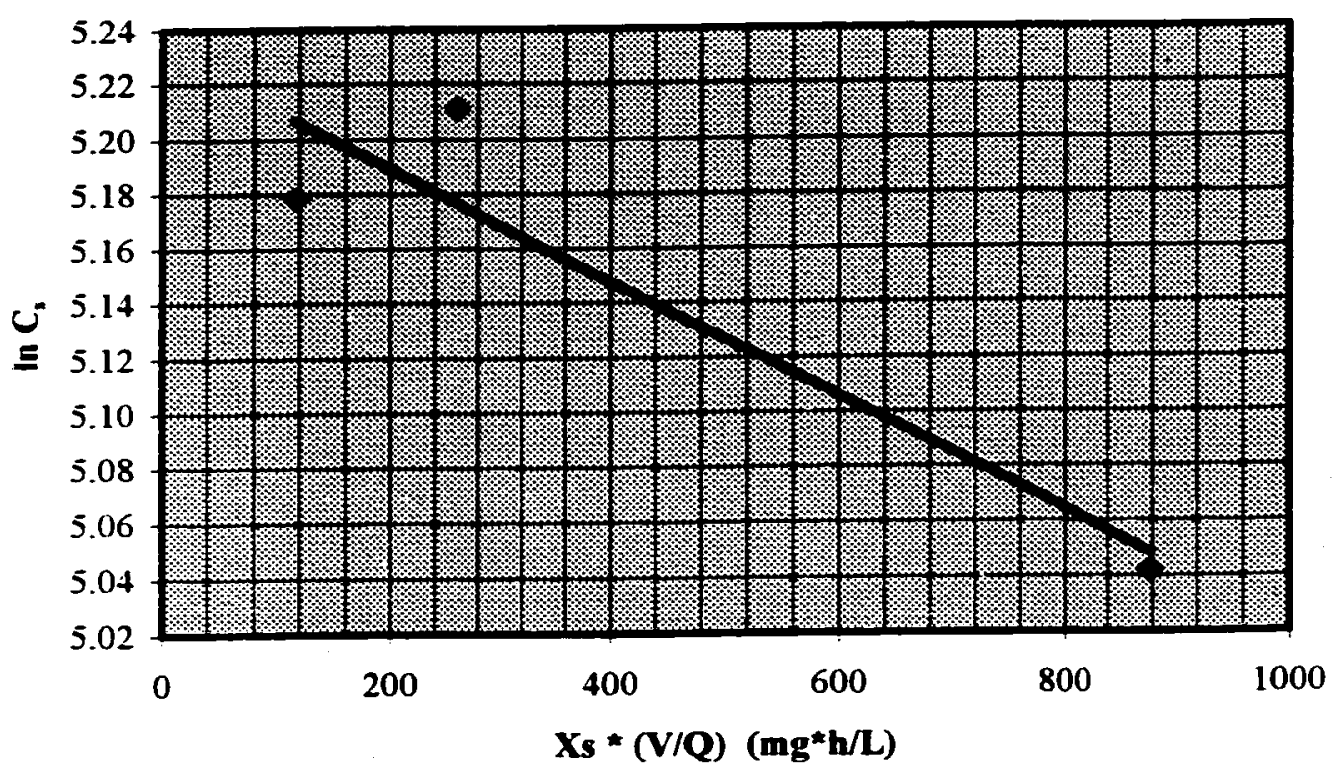

Figure 5.42 Model III: Sulfide and Biomass Concentrations. Reactor I (packed)

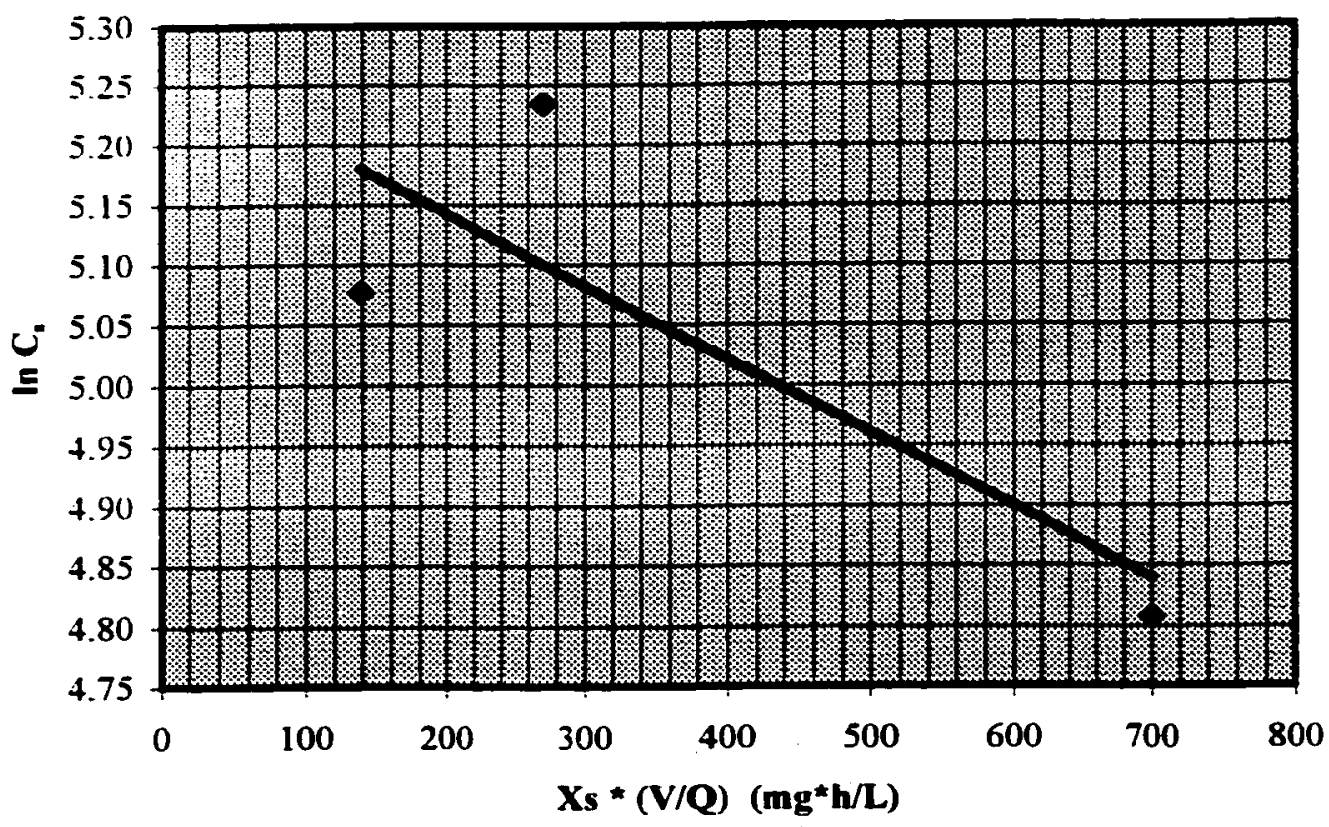

Figure 5.43 Model III: Sulfide and Biomass Concentrations.

Reactor II (non-packed) 


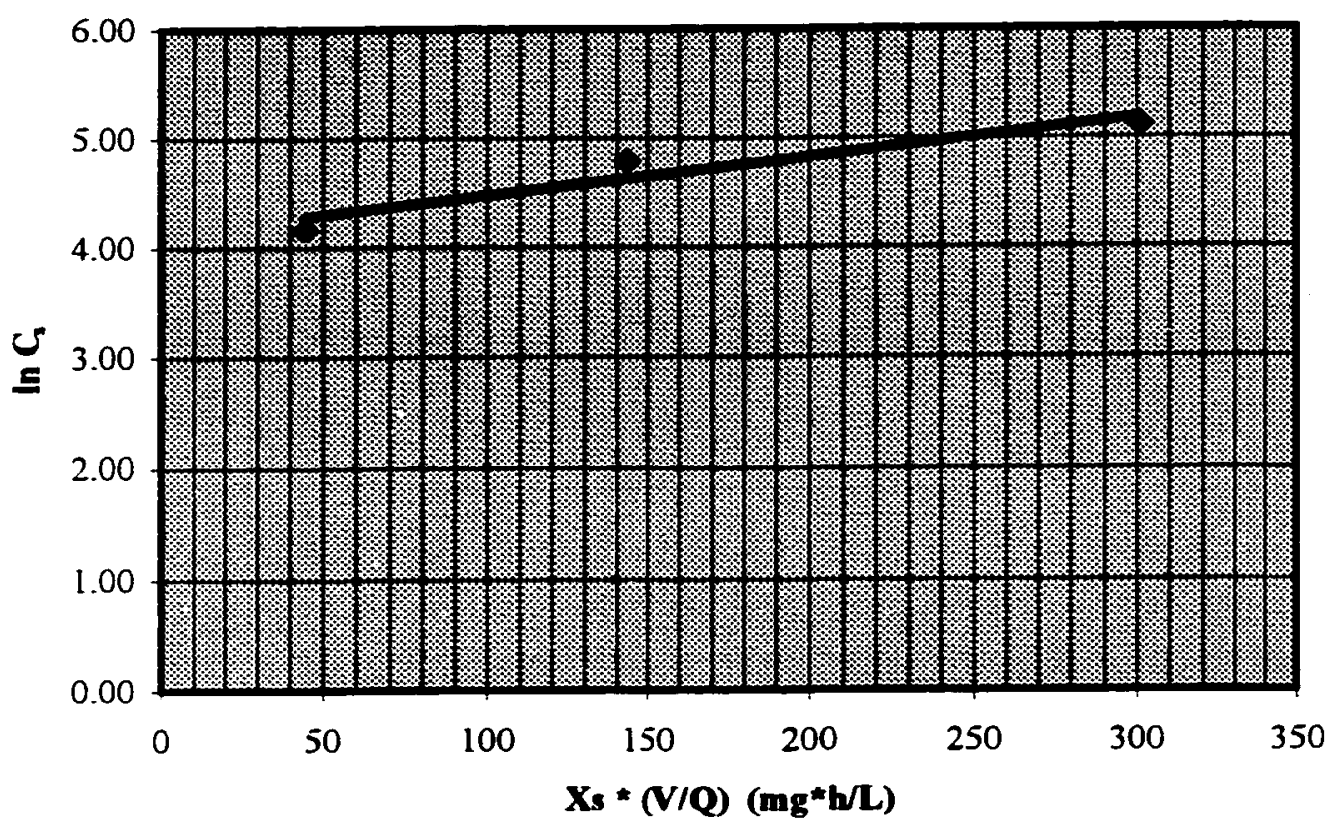

Figure 5.44 Model II: Sulfide and Biomass Concentrations.

Reactor III (non-packed) 


\section{CHAPTER 6. DISCUSSION}

During the present work, three basic operating parameters were studied in order to define the optimum conditions for the operation of an upflow anaerobic reactor, with SRB as the dominant bacteria. These three operating parameters were: feed composition, presence of packing material and hydraulic retention time, which was related to the upflow velocity. The optimization of these parameters was carried out in order to maximize the sulfide production, which was used as an indicator of the reactor performance and the SRB activity.

\subsection{Analytical Techniques}

An important analysis during the experiments was the sulfide analysis, which followed the Standard Method 4500-S $\mathrm{S}^{2-} \mathrm{F}$, as described in Section 3.3.1. All the samples were pretreated to eliminate interferences and to concentrate sulfide. The analysis results represented $90 \%$ of the total sulfide observed in the sample without pretreatment.

All the analyses during the continuous operation of the reactors were carried out once every second day, until the steady state was reached, generally after 5 to 8 times the hydraulic retention time tested. The steady state is defined as keeping the fluctuations in concentrations within the statistical variation for each specific analysis as calculated in Appendix C. The steady state sulfide and VSS concentrations used for analysis of data were the average of the last three values. 


\subsection{Phase I}

Since the bacteria were in the acclimatization period, a less concentrated substrate was used. An increase in sulfide concentration was observed after about 20 days showing an acclimatized SRB culture. After the first 40 consecutive days, the stationary phase was reached, which was confirmed by stable ORP and $\mathrm{pH}$ values. It can be seen that obtaining a healthy SRB culture is a long process, basically due to the type of substrate used and the type of seed used to start the reactors.

In an acetate fed reactor, Omil et al. (1997) detected sulfidogenic acetate degradation after 50 days, while just $10 \%$ of the acetate was degraded by the ASRB after 100 days. The researchers concluded that methods that rely on the development of an SRB population with time would require a long process.

For a healthy SRB activity in the sulfide production and the corresponding reduction of sulfate, factors like pH and ORP had to be kept within the optimum values. Even though sulfide concentrations were always detected, a healthy SRB activity was considered only after a sulfide concentration of $120-130 \mathrm{mg} / \mathrm{L}$ was reached in the $2 \mathrm{~L}$ reactors. Significant fluctuations in the results were noticed until the sulfide concentration gradually reached the steady state. 


\subsection{Phase II}

One of the most important limitation in the batch study of the $10 \mathrm{~L}$ reactors was the channeling within the reactors. Since no mixing device was used, channeling of the feed solution within the sludge bed could have taken place during the experiment. The samples were not representative of the reactors' content because there was no mixing available to provide a uniform sample.

\subsubsection{Substrate Composition}

It was observed that the reactors performed better and higher sulfide concentrations were obtained when the initial substrate composition was changed. Although the Th.O.D.:SO 4 and the Th.O.D.:N:P were the same in all formulations, five main changes were made:

1. Sulfate Source. Magnesium sulfate $\left(\mathrm{MgSO}_{4} * 7 \mathrm{H}_{2} \mathrm{O}\right)$, used in the first batch substrate formulation, was changed to ammonium sulfate $\left(\left(\mathrm{NH}_{4}\right)_{2} \mathrm{SO}_{4}\right)$ and sodium sulfate $\left(\mathrm{Na}_{2} \mathrm{SO}_{4}\right)$, thereby eliminating the high concentrations of magnesium (above $3000 \mathrm{mg} / \mathrm{L}$ ), which may have caused strong inhibition in the anaerobic process (Speece, 1996).

2. Nitrogen Source. Ammonium chloride was replaced by ammonium sulfate, which functioned both as sulfate source and nitrogen source. The optimum nitrogen concentration for SRB growth reported by El Bayoumy (1997) was between 250 
and $500 \mathrm{mg} / \mathrm{L}$. The first batch formulation had nitrogen concentrations above this level, while the new substrate nitrogen content was within the optimum limits.

3. Sodium Concentration. A moderate inhibition was probably caused by the sodium concentration of $3500-5500 \mathrm{mg} / \mathrm{L}$ in the first batch substrate formulation. The sodium concentration was reduced to $1900 \mathrm{mg} / \mathrm{L}$ in the new formulation and was maintained below the moderate inhibitory concentrations (Speece, 1996).

4. Buffers Ratio. A Th.O.D. to P ratio of 100:1 was kept for the new formulation, but the ratio between the potassium di-hydrogen phosphate $\left(\mathrm{KH}_{2} \mathrm{PO}_{4}\right)$ and dipotassium hỵdrogen phosphate $\left(\mathrm{K}_{2} \mathrm{HPO}_{4}\right)$ was changed from $1: 4$ to $1: 2$.

5. Trace Elements Iron, Nickel, Copper, Zinc, Manganese, Boron and Cobalt were added as trace elements in the new formulation since deionized water was used for the preparation of all the solutions.

\subsubsection{Profiles of Sulfide and VSS}

Profiles of sulfide and VSS were studied along the reactors' height during the $4^{\text {th }}$ sequence of Phase II. No significant difference in concentrations along the reactors' height was found during the batch operation of the three $10 \mathrm{~L}$ reactors. However, Reactor I (packed) showed more uniform sulfide and VSS concentrations along its height as compared to the other reactors. It should be noted that the VSS concentrations obtained were not representative because the samples did not include solids settled within the packing material. Additionally, the biomass in Reactor I (packed) had settled more uniformly throughout the reactor and therefore had produced higher sulfide 
concentrations with lower VSS in suspension. Figures 5.14, 5.15 and 5.16 show sulfide and VSS concentrations for Reactor I (packed), Reactor II (non-packed) and Reactor III (non-packed), respectively. Figure 5.17 show the combined results for Reactor II and III. The sulfide and VSS concentrations plotted for each reactor represent the average along the reactor's height for each day of analyses during the $4^{\text {th }}$ sequence. Although Reactor II and Reactor III, both non-packed, were started at different VSS concentrations, they showed similar correlations between sulfide and VSS concentrations.

The observed VSS concentrations corresponded to the VSS in suspension. However, the observed VSS concentrations in suspension did not represent the actual biomass present in the reactors because a portion of the biomass had settled down at the bottom of the reactors. The influence on sulfide production of this settled biomass was neglected for mass balance calculations since it was observed that the settling velocity of the biomass was low enough to allow solids to remain in suspension during 3 to 5 day period of time used in the study.

\subsubsection{Stoichiometry}

Stoichiometrical analyses and kinetic rates were used to determine important microbial reaction characteristics. First, the mass and electron balances of VSS and sulfide were carried out using the results from the batch operation of the three $10 \mathrm{~L}$ anaerobic reactors. 
Dissimilatory sulfate reduction can be represented by the following stoichiometric equations:

1. Energy: oxidation of an organic carbon source. In the present study, lactate was the electron donor.

2. Sulfate reduction: sulfate functioned as the electron acceptor.

3. Synthesis: formation of bacterial cells considered as VSS.

The appropriate equations were developed in Chapter 4 and from the results of the mass and electron balance calculations presented in Chapter 5, Tables 5.2, 5.3 and 5.4, it was possible to obtain the proportions in which the reactions mentioned above were taking place. It was determined that about $70 \%$ of the organic matter (lactate) was bio-oxidized, while $30 \%$ was bio-synthesized in non-packed reactors.

The overall stoichiometric equation was obtained by summing the oxidation-reduction equation with the synthesis equation in the ratios mentioned above:

Multiplying Equation 4.4 by 0.7 gives:

$0.058 \mathrm{C}_{3} \mathrm{H}_{5} \mathrm{O}_{3}^{-}+0.088 \mathrm{SO}_{4}{ }^{2-} \rightarrow 0.117 \mathrm{H}_{2} \mathrm{O}+0.088 \mathrm{~S}^{2-}+0.117 \mathrm{CO}_{2}+0.058 \mathrm{HCO}_{3}^{-}$ 6.1

Multiplying Equation 4.5 by 0.3 gives:

$0.025 \mathrm{C}_{3} \mathrm{H}_{5} \mathrm{O}_{3}{ }^{-}+0.01 \mathrm{CO}_{2}+0.015 \mathrm{NH}_{4}{ }^{+} \rightarrow 0.015 \mathrm{C}_{5} \mathrm{H}_{7} \mathrm{O}_{2} \mathrm{~N}+0.035 \mathrm{H}_{2} \mathrm{O}+0.01 \mathrm{HCO}_{3}{ }^{-}$ 
Summing Equation 6.1 and Equation 6.2 gives:

$0.083 \mathrm{C}_{3} \mathrm{H}_{5} \mathrm{O}_{3}{ }^{-}+0.088 \mathrm{SO}_{4}{ }^{2-}+0.015 \mathrm{NH}_{4}{ }^{+} \rightarrow 0.015 \mathrm{C}_{5} \mathrm{H}_{7} \mathrm{O}_{2} \mathrm{~N}+0.088 \mathrm{~S}^{2-}+0.152 \mathrm{H}_{2} \mathrm{O}+0.107 \mathrm{CO}_{2}+0.06$

Dividing Equation 6.3 by 0.088 gives the overall sulfate reduction equation:

$$
0.943 \mathrm{C}_{3} \mathrm{H}_{5} \mathrm{O}_{3}{ }^{-}+\mathrm{SO}_{4}{ }^{2-}+0.17 \mathrm{NH}_{4}{ }^{+} \rightarrow 0.17 \mathrm{C}_{5} \mathrm{H}_{7} \mathrm{O}_{2} \mathrm{~N}+\mathrm{S}^{2-}+1.727 \mathrm{H}_{2} \mathrm{O}+1.216 \mathrm{CO}_{2}+0.773 \mathrm{H}
$$

Using the following molecular masses in Equation 6.4 gives the ratios in which sulfates, lactate and sulfide were reacting:

MM lactate ion $=89$

$\mathrm{MM} \mathrm{SO}_{4}:-10 n=90$

$\mathrm{MM} \mathrm{S}^{2-}$ ion=i2

MM C, H.O, $\mathrm{N}$ as cells $=113$

Thus,

$$
\begin{aligned}
& \text { Lactate }+ \text { Sulfate } \rightarrow \text { Sulfide }+ \text { Cells } \\
& \left(0.943^{* 89}\right)+96 \rightarrow 32+\left(0.17^{*} 113\right)
\end{aligned}
$$

Dividing by 9.6 ,

$$
8.74 \mathrm{mg} / \mathrm{L}+10 \mathrm{mg} / \mathrm{L} \rightarrow 3.33 \mathrm{mg} / \mathrm{L}+2 \mathrm{mg} / \mathrm{L}
$$

Therefore,

$$
\frac{\text { Sulfide }}{\text { Sulfate }}=\frac{1}{3}
$$




$$
\begin{aligned}
& \frac{\text { Lactate }}{\text { Sulfate }}=0.87 \\
& \frac{\text { Lactate }}{\text { Sulfide }}=2.6
\end{aligned}
$$

The Th.O.D., defined as the amount of oxygen in $\mathrm{mg} / \mathrm{L}$ required to stabilize an equivalent amount of organic matter in $\mathrm{mg} / \mathrm{L}$, was calculated by the following equations:

$$
\begin{array}{cccc}
\text { Lactate }+ & \text { Th.O.D. } & \rightarrow & \text { Carbon Dioxide }+ \text { Water } \\
\mathrm{C}_{3} \mathrm{H}_{5} \mathrm{O}_{3}^{-}+\mathrm{O}_{2} & \rightarrow & 3 \mathrm{CO}_{2}+3 \mathrm{H}_{2} \mathrm{O} \ldots \ldots .6 .8
\end{array}
$$

Where,

$$
\text { Th.O.D. }=\frac{96}{89} * \text { Lactate }=1.08 * \text { Lactate }
$$

Therefore,

$$
\frac{\text { Th.O.D. }}{\mathrm{SO}_{4}}=0.87 * 1.08=0.94
$$

These balanced equations indicate that the energy production reaction dominated over the synthesis reaction If is shown that the experimental lactate to sulfate ratio was equal to 0.87 and the corresponding Th.O.D.:SO 4 was equal to 0.94 , which is below 2 as suggested by Annachhatre and Suktrakoolvait (2001). 


\subsection{Phase III}

All reactors were operated in a continuous flow mode in this phase of the study. The data used for discussion are those obtained after steady state, which generally was reached in 5-8 times the hydraulic retention time.

Under continuous operation, the optimization of OLR, Th.O.D.:SO $\mathrm{S}_{4}$ total nitrogen loading rate, total phosphorus loading rate and Th.O.D.N:P, is essential in order to operate a SRB system efficiently. Therefore, the optimum values of these parameters were kept the same as recommended by El Bayoumy (1997).

Other important operating parameters include the nature of support media for bacterial growth, attached or suspended, the hydraulic retention time and the biomass characteristics. These parameters were varied in this phase to maximize the sulfide production and, therefore, optimize SRB activity in an upflow anaerobic suspended growth reactor. The concentrations of possible inhibitory cations, such as $\mathrm{Mg}$ and $\mathrm{Na}$, and nitrogen concentrations were kept within acceptable limits: $3-42 \mathrm{mg} / \mathrm{L}, 480-4800 \mathrm{mg} / \mathrm{L}$ and $60-630 \mathrm{mg} / \mathrm{L}$, respectively.

\subsubsection{General}

Table 5.10 summarizes the steady state data collected from first port and effluent under different operating conditions of HRT and OLR. 
The sulfide concentrations at the first port and the effluent were similar, within statistical variations, indicating that the active volume of the reactor for biomass growth and sulfide production was within the first $300 \mathrm{~mm}$ of reactor's height. However, when the OLR was increased from 6 to $12 \mathrm{~kg} / \mathrm{d} / \mathrm{m}^{3}$, the sulfide concentration gradient between the first port and the effluent clearly indicates that the active volume had increased to above the first port.

As mentioned previously, VSS concentrations do not strictly represent the concentration of active biomass because a portion of the biomass had settled down at the bottom of the reactors. The VSS concentrations were generally higher at the first port than in the effluent showing a slight gradient along the column height.

When the HRT was reduced by increasing the upflow velocity, the VSS concentrations in the reactors were reduced indicating higher washout of biomass.

\subsubsection{Support Media}

Two reactors were run in parallel under similar conditions, with one packed reactor, I, and the other non-packed, II. The support media or packing material consisted of $16 \mathrm{~mm}$ polypropylene pall rings with a porosity of $90 \%$.

The packed reactor showed comparatively less variations in the sulfide and VSS concentrations during all the experiments at different hydraulic retention times and 
different depths. An interesting finding, as shown in Table 5.10, was that the steady state sulfide and VSS concentrations for the packed and the non-packed reactors, operated under the same conditions, were similar, and the variations in concentrations observed in the two reactors are considered to be statistical variations.

It is noteworthy that the observed VSS concentrations corresponded to the biomass that was in suspension along the reactors' height and that was washed out from the reactor. The actual VSS concentration may have been higher because a portion of the biomass had settled at the bottom within the first $300 \mathrm{~mm}$ of the reactors' height.

The conclusions of several other studies agree with the findings of the present work. Alphenaar et al (1993). Omil et al. (1997) and Dries et al. (1998) observed that SRB had poor attachment properies and the presence of a support media did not improve the performance of the ssistem

Therefore, after considerıng the additional cost of packing material, it is concluded that there is no significant adiantage in using packed bed reactors for SRB growth.

\subsubsection{Hydraulic Retention Time}

The effect of hydraulic retention time on the performance of three upflow anaerobic reactors was studied hy varging the HRT between 5 and $50 \mathrm{~h}$. 
From the results shown in Table 5.10 and Figures 5.28, 5.29 and 5.30, it can be observed that both packed and non-packed reactors presented a similar behavior. Figure 5.31 shows that 20-30 h was the optimum hydraulic retention time range for sulfide production. At lower HRT, the sulfide concentration and the mass of sulfide produced per day decreased due to the higher washout of biomass and the reduced time available for the sulfide production reaction. On the other hand, at higher HRT the sulfide concentration and the mass of sulfide produced per day decreased. It is believed that the biomass was fluidized at $20-30 \mathrm{~h}$ of HRT, whereas it remained as a compact bed at $50 \mathrm{~h}$ of HRT. A fluidized bed provided much higher contact between the substrate and the active bacteria as compared to the compact bed.

The maximum sulfide concentrations observed are given below:

1. Reactor I, packed, achieved the maximum concentration of $195 \mathrm{mg} \mathrm{S} / \mathrm{L}$ at $20-30 \mathrm{~h}$ of retention time.

2. Reactor II, non-packed, achieved the maximum concentration of $186 \mathrm{mg} \mathrm{S} / \mathrm{L}$ at $20-30 \mathrm{~h}$ of retention time.

3. Reactor III, non-packed, achieved the maximum concentration of $180 \mathrm{mg} \mathrm{S} / \mathrm{L}$ at 20-30 $\mathrm{h}$ of retention time.

The average of these three maximum sulfide concentrations is $187 \mathrm{mg} \mathrm{S} / \mathrm{L}$.

The maximum sulfide concentrations were similar in all three reactors and within the statistical variations of the tests. The combined effect of the hydraulic retention time and 
the packing material shows that the maximum sulfide concentration was reached within the same range of retention time for the packed reactor as for the non-packed reactor.

It is also observed that the VSS concentrations in the effluent and first port in all reactors had increased with an increase in HRT because there was more time for bacterial growth and, therefore, higher biomass concentration was present in the reactor. On the other hand, VSS had rapidly decreased due to washout of biomass when the HRT was below $10 \mathrm{~h}$.

The maximum rates of sulfide production are listed below:

1. Reactor I (packed) achieved the maximum rate of $2450 \mathrm{mg} \mathrm{S} / \mathrm{d}$ at $20 \mathrm{~h}$ of retention time.

2. Reactor II (non-packed) achieved the maximum rate of $2310 \mathrm{mg} \mathrm{S} / \mathrm{d}$ at $20 \mathrm{~h}$ of retention time.

3. Reactor 111 (non-packed) achieved the maximum rate of $1930 \mathrm{mg} \mathrm{S} / \mathrm{d}$ at $20 \mathrm{~h}$ of retention time.

The average of these three maximum rates of sulfide production is $2230 \mathrm{mg} \mathrm{S} / \mathrm{d}$.

The maximum rates of sulfide production were similar regardless of the type of reactor, packed or non-packed, as shown in Table 5.11 and Figures 5.32, 5.33 and 5.34. The variations in results between different reactors are considered to be statistical variations. It can be seen that the maximum rate of sulfide production was not dependent on the type 
of SRB growth involved, attached or suspended, and it was achieved at an optimum retention time of $20 \mathrm{~h}$ as shown in Figure 5.35.

It is concluded that the hydraulic retention time is an important parameter in the design and operation of anaerobic reactors. The optimum HRT ranged between 20 and $30 \mathrm{~h}$. Below $10 \mathrm{~h}$ of HRT, the SRB activity, and therefore the concentration of sulfide, became so low that the overall performance of the system was not satisfactory. The loss of SRB activity at HRT below $10 \mathrm{~h}$ was mainly due to the washout of biomass caused by the high upflow velocity.

The hydraulic retention time, HRT, is related to the hydraulic loading rate, HLR and the upflow velocity, $V_{0}$, as shown below:

$$
H R T=\frac{V}{Q}=\frac{A^{*} H}{Q}=\frac{H}{\left(\frac{Q}{A}\right)}=\frac{H}{H L R}=\frac{H}{V_{0}}
$$

Where,

HRT $=$ hydraulic retention time $(d)$

$\mathrm{V}=$ reactor's volume $\left(\mathrm{m}^{3}\right)$

$Q=$ flow rate $\left(\mathrm{m}^{3} / \mathrm{d}\right)$

$A=$ cross sectional area $\left(\mathrm{m}^{2}\right)$

$H=$ reactor's height $(\mathrm{m})$

HLR = hydraulic loading rate $\left(\mathrm{m}^{3} / \mathrm{m}^{2} / \mathrm{d}\right)$

$V_{\mathrm{o}}=$ upflow velocity $(\mathrm{m} / \mathrm{d})$ 
In these reactors, the maximum rate of sulfide production had been reached at $1.5 \mathrm{~m} / \mathrm{d}$ of $\mathrm{V}_{\mathrm{o}}, 20 \mathrm{~h}$ of HRT. This value showed an optimum performance of the system along with a small VSS washout. On the other hand, there was a complete washout at $5 \mathrm{~h}$ of HRT and $5.9 \mathrm{~m} / \mathrm{d}$ of $\mathrm{V}_{\mathrm{o}}$. El Bayoumy (1997) had recommended $11 \mathrm{~h}$ as the optimum HRT for an UAFF reactor.

In a supporting study, Dvorak et al. (1992) found that the hydraulic flow rate significantly affected the performance of the anaerobic system. At shorter residence times, the upflow anaerobic reactors were not as effective not only because there was insufficient time for bacterial activity to remove metals but it also dislodged solids and prevented the precipitates from settling. On the other hand, longer residence times may limit the reactor to small influent loads of metals.

\subsubsection{Effect of Organic Loading Rate}

Table 5.10 and Figure 5.31 show that when the organic loading rate was doubled from 6 $\mathrm{kg} / \mathrm{d} / \mathrm{m}^{3}$ to $12 \mathrm{~kg} / \mathrm{d} / \mathrm{m}^{3}$, at the same hydraulic retention time and upflow velocity, the mass of sulfide produced, as measured in the effluent, had also increased proportionately. Similarly, the mass of VSS produced in the effluent had increased with an increase in OLR. The rate of sulfide production under different organic loading rates at $10 \mathrm{~h} \mathrm{HRT}$ are listed below: 


\section{First Port}

1. Reactor III (non-packed) produced $1470 \mathrm{mg} \mathrm{S} / \mathrm{d}$ at $6 \mathrm{~kg} / \mathrm{d} / \mathrm{m}^{3}$ of organic loading rate.

2. Reactor II (non-packed) produced $1230 \mathrm{mg} \mathrm{S} / \mathrm{d}$ at $12 \mathrm{~kg} / \mathrm{d} / \mathrm{m}^{3}$ of organic loading rate.

\section{Emuent}

1. Reactor III (non-packed) produced $1700 \mathrm{mg} \mathrm{S} / \mathrm{d}$ at $6 \mathrm{~kg} / \mathrm{d} / \mathrm{m}^{3}$ of organic loading rate.

2. Reactor II (non-packed) produced $3820 \mathrm{mg} \mathrm{S} / \mathrm{d}$ at $12 \mathrm{~kg} / \mathrm{d} / \mathrm{m}^{3}$ of organic loading rate.

It was observed that doubling the OLR increased the active volume. At $300 \mathrm{~mm}$, first sampling port, the mass of sulfide produced with $12 \mathrm{~kg} / \mathrm{d} / \mathrm{m}^{3}$ was similar to the one obtained with $6 \mathrm{~kg} / \mathrm{d} / \mathrm{m}^{3}$. However, at the effluent port, $12 \mathrm{~kg} / \mathrm{d} / \mathrm{m}^{3}$ of OLR produced more than twice the sulfide mass as compared to $6 \mathrm{~kg} / \mathrm{d} / \mathrm{m}^{3}$ of OLR. Singh et al. (1996) have reported that at higher OLR, the settling characteristics of the biomass were poorer and it was possible an increase in the solids distribution and, therefore, an increase in active height.

Since the rate of lactate consumption is proportional the concentration of lactate present, when the latter is increased the rate of organic matter consumption increases proportionally. From Equation 5.4, it can be observed that the rate of lactate consumption 
is proportional to the rate of sulfide production and therefore, doubling the OLR would double the rate of sulfide production.

It was confirmed that the sulfide decreased as the HRT was decreased, regardless of the OLR. This was observed within a hydraulic retention time range of 7.5 and $12 \mathrm{~h}$ in upflow anaerobic suspended growth reactors.

\subsection{5 pH and ORP}

Mizuno et al. (1998b) has mentioned that the $\mathrm{pH}$ value is a key factor affecting sulfate reduction. The $\mathrm{pH}$ and ORP in the reactors were checked throughout the experiments. It was observed that the effluent $\mathrm{pH}$ ranged between 6.5 and 7.0 and the ORP values fluctuated between -300 and $-390 \mathrm{mV}$, which are within the optimum limits reported for a healthy SRB environment. The substrate composition with its $\mathrm{pH}(7.0 \pm 0.1)$ and its buffering capacity, helped in maintaining the effluent $\mathrm{pH}$ in the range mentioned.

Sulfate reducers prefer an environment around $\mathrm{pH} 7.0$ and are usually inhibited at $\mathrm{pH}$ values lower than 6.0 or higher than 9.0 (Perry, 1995). Mizuno et al. (1998b) has stated that a low $\mathrm{pH}$ is not recommended because of possible inhibition to SRB growth facilitated by the formation of $\mathrm{H}_{2} \mathrm{~S}$ according to the following equation:

$$
\mathrm{H}_{2} \mathrm{~S} \leftrightarrow \mathrm{H}^{+}+\mathrm{HS}^{-}
$$


Similarly, the ORP values below $-150 \mathrm{mV}$ are an indicator of sulfide production and activity of SRB (Postgate, 1984).

\subsubsection{Kinetics}

In this study, the total sulfide concentration in the reactors was below the toxic and inhibitory concentrations reported in the literature, i.e. $250-600 \mathrm{mg} \mathrm{S} / \mathrm{L}$ (Okabe et al., 1992; Reis et al.. 1992; Okabe et al., 1995). Additionally, the pH was kept between 6.5 and 7.0 , which means that the hydrogen sulfide concentration was less than $50 \%$ of the total sulfide concentration. Thus, the concentration of hydrogen sulfide, a strong inhibitor for SRB growth. was minimized through the $\mathrm{pH}$ control within a narrow range.

The results from the upflow anaerobic reactors, in continuous mode operation, were used to develop the kinetic models.

The biochemical transformations in the reactors are mathematically described by mass balance equations in Chapter 4 . The mass balances were based on a plug flow system by considering a differential volume element. An important design parameter is the rate constant of the process, which was obtained through the plug flow reactor model up to the first port, $300 \mathrm{~mm}$ above the influent. This was done based on the fact that the concentrations above this port were fairly uniform, confirming that significant sulfide production was taking place within the first $300 \mathrm{~mm}$ of the reactor's height. Therefore, the actual hydraulic retention time up to that port was used in calculations. 


\subsubsection{Biomass Production}

The kinetic rate constant for the biomass growth was calculated from the best-fit slope of the $\ln X_{s}$ plotted versus calculated hydraulic retention time, Figures 5.36, 5.37 and 5.38, where $\mathrm{X}_{\mathrm{s}}$ represents the VSS steady state concentration at the first port. According to the calculations in Table 5.12 for Model $I$, the average value of the specific growth rate, $\mu$, was $0.177 \mathrm{~h}^{-1}$.

The values for $\mathrm{Y}$ and $\mathbf{k}$ depended on the hydraulic retention time as shown in Table 5.12. The yield coefficient decreased as the hydraulic retention time decreased, whereas the substrate utilization rate constant increased with a decrease in hydraulic retention time.

\subsubsection{Sulfide Production}

Based on the values for $\mathrm{Y}$ and $\mathrm{k}$ obtained above, the corresponding rates for sulfide production at different hydraulic retention times were calculated from the Equation 5.4 developed previously. The values for $X_{s}$ were calculated using the corresponding model for each reactor as shown in Section 5.3.6.1.

This shows a similarity with McCartney et al. (1990) study. They reported that lactate removal in batch reactors was essentially independent of sulfide concentration.

The sulfide production rates were also calculated using Kinetic Model II developed in Section 5.3.6.2. In this model, it was assumed that the rate of sulfide production was 
directly proportional to the sulfide concentration. The correlations for Model II in Figures $5.39,5.40$ and 5.41 did not show as good fit as correlations for Model I.

The Kinetic Model III developed in Section 5.3.6.3, based on the rate of sulfide production being proportional to the product of biomass and sulfide concentrations, did not show satisfactory sulfide production rate calculations and therefore the calculations were neglected.

Using another approach, the rate of sulfide production per active volume can be calculated using the observed steady state sulfide concentrations at different hydraulic retention times with their corresponding flow rates. These calculations are shown in Table 6.1.

El Bayoumy (1997) had established the following empirical equation for the sulfide production rate in packed reactors:

$$
\frac{\mathrm{dS}}{\mathrm{dt}}=\frac{\mathrm{S}_{\max }}{10^{3} * \mathrm{HRT}}\left[1-\mathrm{e}^{(-0.75 \bullet \mathrm{OLR})}\right]
$$

Where,

$\mathrm{dS} / \mathrm{dt}=$ sulfide production rate $\left[\mathrm{kg} / \mathrm{d} / \mathrm{m}^{3}\right]$

$\mathrm{S}_{\max }=$ maximum sulfide concentration $[\mathrm{mg} / \mathrm{L}$ ]

HRT = hydraulic retention time [d]

OLR = organic loading rate $\left[\mathrm{kg} / \mathrm{d} / \mathrm{m}^{3}\right]$ 
El Bayoumy (1997) had found a maximum sulfide concentration of $140 \mathrm{mg} / \mathrm{L}$ in his experiments, considering the entire reactor volume as the active volume in developing Equation 6.13.

Calculations for sulfide production rate according to Equation 5.4 and 6.13 are shown in Table 6.1.

Table 6.1 Sulfide Production Rate Calculated by Different Methods

\begin{tabular}{|c|c|c|c|c|c|c|}
\hline$\overline{\text { HRT }}$ & $\overline{\text { OLR }}$ & $\begin{array}{c}C_{\mathbf{s}} \\
\text { Observed Steady } \\
\text { State Sulfide } \\
\text { Concentration at } \\
\text { the first port } \\
\end{array}$ & $\overline{\mathbf{Q}}$ & $\frac{Q^{*} C_{s} \text { observed }}{\text { Active volume }}$ & $\begin{array}{c}d C s / d t \\
\text { Equation } \\
5.4\end{array}$ & $\begin{array}{c}\text { dS/dt } \\
\text { Equation } \\
6.13\end{array}$ \\
\hline (h) & $h g / d / m^{3}$ & $\mathbf{m g} / \mathbf{L}$ & $L / d$ & $\mathrm{~kg} / \mathrm{d} / \mathrm{m}^{3}$ & $\mathrm{~kg} / \mathrm{d} / \mathrm{m}^{3}$ & $\mathrm{~kg} / \mathrm{d} / \mathrm{m}^{3}$ \\
\hline \multicolumn{7}{|c|}{ Reactur I } \\
\hline 50 & 6 & 155 & 5.43 & 0.34 & 0.65 & 0.38 \\
\hline 30 & 6 & 183 & 8.56 & 0.64 & 0.77 & 0.70 \\
\hline 20 & 6 & 177 & 12.6 & 0.91 & 0.75 & 1.00 \\
\hline \multicolumn{7}{|c|}{ Reactor II } \\
\hline 50 & 6 & 122 & 5.43 & 0.27 & 0.52 & 0.27 \\
\hline 30 & 6 & 187 & 8.48 & 0.65 & 0.81 & 0.64 \\
\hline 20 & 6 & $\overline{160}$ & 12.7 & 0.83 & 0.68 & 0.82 \\
\hline \multicolumn{7}{|c|}{ Reactor III } \\
\hline 30 & 6 & 166 & 8.25 & 0.56 & 0.73 & 0.55 \\
\hline 20 & 6 & 120 & 12.1 & 0.59 & 0.48 & 0.59 \\
\hline 10 & 6 & 64 & 22.9 & 0.60 & 0.28 & 0.59 \\
\hline
\end{tabular}


Basically four factors can explain the differences found in sulfide production calculated with different methods:

- Type of substrate. Different feed compositions were used in El Bayoumy (1997) studies and the present research work.

- SRB seed culture.

- Reactor's active volume considered in the modeling.

- Variables considered in the different kinetic models.

\subsubsection{Comparison between Batch and Continuous Flow Reactors}

The present study- shows that a better performance and higher sulfide concentrations were reached with the contınuous system as compared to the batch operation.

McCartney and Oleszhiewicz (1993) referred the work of Karhadkar et al. (1987) in which it was concluded that it was difficult to achieve a specific aqueous sulfide concentration in hatch sistems due to the precipitation process and gaseous hydrogen sulfide equilibrium Karhadkar et al. (1987) also noted that the batch reactors performed better with sulfide addition because sulfide was the growth-limiting factor while McCartney and Olesshiewicz (1993) suggested that the oxidation-reduction potential of the media was lowered by the sulfide addition. Okabe et al. (1995) observed SRB growth rates for batch cultures lower than those for continuous cultures. 


\subsubsection{Active Height}

During the continuous operation of the three $10 \mathrm{~L}$ anaerobic reactors, the sulfide concentrations were uniform at different ports along the reactors' height. It is believed that due to the presence of a portion of active sludge in the lower portion of the reactors, which was confirmed by visual observations, major sulfide production occurred within the first $300 \mathrm{~mm}$ of the reactor's height. When the hydraulic retention time was reduced to $10 \mathrm{~h}$, a gradient of sulfide concentrations along the reactor's height was observed, indicating that this hydraulic retention time had started limiting the optimum performance of the system.

Gundry et al. (1990) also concluded that the active removal of nickel as NiS, and regardless of its initial concentration in the influent, occurred in the lower part of an anaerobic filter. Chen et al. (1994) observed in an upflow anaerobic porous media reactor fed with lactate, that most of the lactate was consumed at the front part of the column, and the measurements of SRB biomass on the solid phase, sand, and in the liquid phase, reflected that the maximum concentration of SRB in the solid phase was at the front part of the column, while the maximum in the liquid phase occurred slightly further downstream indicating a SRB detachment phenomenon.

Rivera (1983) studied the heavy metal removal in an upflow anaerobic packed-bed bioreactor, finding that the soluble metal removal took place mainly in the lower regions, within the first $500 \mathrm{~mm}$ of the column. The author observed that at steady-state 
conditions, more than $80 \%$ of the soluble COD was removed within the first $300 \mathrm{~mm}$ of the column with $120 \mathrm{~mm}$ diameter, and concluded that most of the biosolids were located at the bottom of the column.

\subsubsection{Heavy Metals Removal}

El Bayoumy (1997) developed equations to calculate the critical reactor height required to remove certain heavy metals i.e. chromium, copper, nickel, zinc, cadmium and lead. Based on that critical height, which is a function of the initial concentration of the heavy metal, and considering the mass of sulfide required to remove certain mass of heavy metal, the reactor design could be established.

The mass of sulfide required for metal precipitation as metal sulfide can be calculated according to the following equation given by El Bayoumy (1997):

$$
\Delta \mathrm{Sr}=\Delta \mathrm{Mr} *\left[\frac{\mathrm{Ws}}{\mathrm{Wm}}\right]=\left[\left(\mathrm{C}_{\mathrm{i}}-\mathrm{C}_{\mathrm{e}}\right) * \frac{\mathrm{Ws}}{\mathrm{Wm}}\right] * \mathrm{Q}_{\mathrm{i}}^{*} \Delta \mathrm{t}
$$

Where,

$\Delta \mathrm{Sr}=$ mass of sulfide required for heavy metals removal [mg]

$\Delta \mathrm{Mr}=$ mass of heavy metal to remove $[\mathrm{mg}]$

$\mathrm{Ws}=$ molecular mass of sulfide $[\mathrm{mg} / \mathrm{mgmol}]$

$\mathrm{Wm}=$ molecular mass of heavy metal $[\mathrm{mg} / \mathrm{mgmol}]$

$\mathrm{C}_{\mathrm{i}}=$ influent heavy metal concentration [ $\mathrm{mg} / \mathrm{L}$ ]

$\mathrm{C}_{\mathrm{e}}=$ effluent heavy metal concentration $[\mathrm{mg} / \mathrm{L}]$ 
$\mathrm{Q}_{\mathrm{i}}=$ flow rate $[\mathrm{L} / \mathrm{d}]$

$\Delta \mathrm{t}=$ time $[\mathrm{d}]$

Considering the optimum retention time of $20 \mathrm{~h}$ with a corresponding flow of $12.7 \mathrm{~L} / \mathrm{d}$, influent metal concentrations of $75-100 \mathrm{mg} \mathrm{Cr} / \mathrm{L}, 200-350 \mathrm{mg} \mathrm{Cu} / \mathrm{L}, 150-200 \mathrm{mg} \mathrm{Ni} / \mathrm{L}$, 150-200 $\mathrm{mg} \mathrm{Zn/L}, 50-75 \mathrm{mg} \mathrm{Cd} / \mathrm{L}$ and $40-50 \mathrm{mg} \mathrm{Pb} / \mathrm{L}$, which are within the non-toxic levels as recommended by El Bayoumy (1997), would be $>90 \%$ removed in an upflow anaerobic suspended growth reactor with maximum sulfide concentrations of $190 \mathrm{mg} / \mathrm{L}$.

Using the equations developed previously by El Bayoumy (1997) for metal applications, an active height of $300 \mathrm{~mm}$ would allow $100 \%$ removal of the heavy metal applied at an influent concentrations of $48 \mathrm{mg} \mathrm{Cr} / \mathrm{L}, 95 \mathrm{mg} \mathrm{Cu} / \mathrm{L}, 90 \mathrm{mg} \mathrm{Ni} / \mathrm{L}, 88 \mathrm{mg} \mathrm{Zn} / \mathrm{L}, 44 \mathrm{mg}$ $\mathrm{Cd} / \mathrm{L}$ and $29 \mathrm{mg} \mathbf{P b} \mathrm{L}$ 


\section{CHAPTER 7. CONCLUSIONS AND RECOMMENDATIONS}

\subsection{Conclusions}

1. A long process was required to develop a healthy SRB culture, basically due to the type of substrate used and the type of seed used to start the batch anaerobic reactors. A healthy SRB activity was considered only after a sulfide concentration of $120-130 \mathrm{mg} / \mathrm{L}$ was reached in the batch anaerobic reactors.

2. No significant difference in concentrations along the reactors' height was found during the batch operation of three $10 \mathrm{~L}$ reactors regardless of the type of SRB growth involved, attached or suspended. However, a portion of the biomass had settled at the bottom.

3. From the mass and electron balances during the batch study, it was observed that $70 \%$ of the lactate fed was bio-oxidized while the $30 \%$ was bio-synthesized, which indicates that the energy production reaction predominated over the synthesis reaction in non-packed reactors.

4. The experimental lactate to sulfate ratio was equal to 0.87 and the corresponding Th.O.D.: $\mathrm{SO}_{4}$ was equal to 0.94 , which is below 2 as suggested by Annachhatre and Suktrakoolvait (2001). 
5. In the continuous operation of three $10 \mathrm{~L}$ anaerobic reactors, an acclimatized culture of sulfate reducing bacteria, SRB, could reduce the inflow sulfates to sulfide effluent concentrations up to $180-190 \mathrm{mg}$ of $\mathrm{S} / \mathrm{L}$, both in packed and nonpacked reactors. The effect of the hydraulic retention time on the sulfide production, used as an indicator of an upflow anaerobic suspended growth reactor performance, was evident.

6. The SRB had poor attachment properties and the presence of a support media did not show any increase in effluent sulfide concentrations and thus any improvement in the performance of the system. The additional cost of packing material is not justified.

7. The maximum rate of sulfide production, $2230 \mathrm{mg} \mathrm{S} / \mathrm{d}$ on an average, was not dependent on the type of SRB growth involved, attached or suspended, and it was achieved at an optimum HRT of $20 \mathrm{~h}$ with a corresponding upflow velocity of 1.5 $\mathrm{m} / \mathrm{d}$. Below $10 \mathrm{~h}$ of HRT, the SRB activity, and therefore the concentration of sulfide, became so low that the overall performance of the system was not satisfactory. The loss of SRB activity at HRT below $10 \mathrm{~h}$ was mainly due to the washout of biomass caused by the high upflow velocity, above $3 \mathrm{~m} / \mathrm{d}$.

8. It was observed that doubling the OLR increased proportionally the rate of sulfide production. Similarly, the active volume had increased as a result of poorer 
settling characteristics of the biomass and, therefore, an increase in the solids distribution.

9. The substrate utilization rate constant, $\mathbf{k}$, which was obtained through a plug flow reactor model for VSS up to the first port, $300 \mathrm{~mm}$ above the reactor's bottom, was found to be $2.53 \mathrm{~h}^{-1}$ on an average, for the optimum retention time of $20 \mathrm{~h}$. The average specific growth rate, $\mu$, was $0.177 \mathrm{~h}^{-1}$.

\subsection{Recommendations}

1. Experiments should be conducted to determine the actual metal application for the operation of an upflow anaerobic suspended growth reactor under the conditions studied.

2. Further work is required to determine biomass concentrations near the bottom of the reactor and its influence on the performance of the system.

3. Studies are required on the behavior of SRB fed with a specific industrial wastewater, to determine the suitability of this system for those particular carbon and sulfate sources.

4. The scale-up study of the present design should be considered and further work is required to establish the necessary procedures for start-up, adaptation and optimum performance at an industrial scale.

5. Studies are required to determine the effect of temperature in the performance of the system. 


\section{REFERENCES}

APHA, AWWA, \& WEF (1995). Standard Methods for the Examination of Water and Wastewater (19 $9^{\text {th }}$ edition). Washington, DC: American Public Health Association.

Agrawal, L.K., Harada, H., \& Okui H. (1997a). Treatment of Dilute Wastewater in a UASB Reactor at a Moderate Temperature: Microbiological Aspects. Journal of Fermentation and Bioengineering, 83 (2), 185-190.

Agrawal, L.K., Harada, H., \& Okui H. (1997b). Treatment of Dilute Wastewater in a UASB Reactor at a Moderate Temperature: Performance Aspects. Journal of Fermentation and Bioengineering, 83 (2), 179-184.

Alphenaar, P.A., Visser, A., \& Lettinga, G. (1993). The Effect of Liquid Upflow Velocity and Hydraulic Retention Time on Granulation in UASB Reactors Treating Wastewater with a High Sulfate Content. Bioresource Technology, 43, 249-258.

Annachhatre, A.P and Suktrakoolvait S. (2001). Biological Sulfate Reduction Using Molasses as a Carbon Source. Water Environment Research, 73 (1), 118-126.

Bhattacharya, S.K., Uberoi, V., \& Dronamraju, M.M. (1996). Interaction between Acetate Fed Sulfate Reducers and Methanogens. Water Research, 30 (10), 2239-2246. 
Brock, T.D. and Madigan, M.T. (1991). Biology of Microorganisms (6 ${ }^{\text {th }}$ edition). Englewood Cliffs, NI: Prentice-Hall.

Chen, C., Mueller, R.F., \& Griebe, T. (1994). Kinetic Analysis of Microbial Sulfate Reduction by Desulfovibrio Desulfuricans in an Anaerobic Upflow Porous Media Biofilm Reactor. Biotechnology and Bioengineering, 43, 267-274.

Choi, E. \& Rim, J.M. (1991). Competition and Inhibition of Sulfate Reducers and Methane Producers in Anaerobic Treatment. Water. Science and Technology, 23, 12591264.

De Smul, A., \& Verstraete, W. (1999). Retention of Sulfate-Reducing Bacteria in Expanded Granular-Sludge-Blanket Reactors. Water Environment Research, 71 (4), 427 431.

De Vegt, A.L., \& Buisman, C.J.N. (1996). Sulfur Compounds and Heavy Metal Removal Using Bioprocess Technology. TMS Anmual Meeting, Feb 4-9, 995-1004.

De Vegt, A.L., Bayer, H.G., \& Buisman, C.J. (1999). Biological Sulfate Removal and Metal Recovery from Mine Waters. Mining Engineering, 50 (11), 67-70. 
Dries, J., De Smul, A., Goethals, L., Grootaerd, H., \& Verstraete, W. (1998). High Rate Biological Treatment of Sulfate-Rich Wastewater in an acetate-fed EGSB reactor. Biodegradation, 9, 103-111.

Dvorak, D.H., Hedin, R.S., Edenborn, H.M., \& McIntire, P.E. (1992). Treatment of Metal-Contaminated Water Using Bacterial Sulfate Reduction: Results from Pilot-Scale Reactors. Biotechnology and Bioengineering, 40, 609-616.

El Bayoumy, M.A. (1997). Biological Treatment of Organic Wastes and Heavy Metals form Industrial Wastes. Ph.D. Dissertation, Univ. of Windsor, Windsor, Ont., Canada. $390 \mathrm{p}$.

El Bayoumy, M.A., Bewtra, J.K., Ali, H.I., \& Biswas, N. (1997). Biosorption of Lead by Biomass of Sulfate Reducing Bacteria. Canadian Journal of Civil Engineering, 24, 840843.

El Bayoumy, M.A., Bewtra, J.K., Ali, H.I., \& Biswas, N. (1999a). Sulfate Production by Sulfate Reducing Bacteria with Lactate as Feed in an Upflow Anaerobic Fixed Film Reactor. Water, Air and Soil Pollution, $112,67-84$.

El Bayoumy, M.A., Bewtra, J.K., Ali, H.I., \& Biswas, N. (1999b). Removal of Heavy Metals and COD by SRB in UAFF Reactor. Journal of Environmental Engineering, June, 532-539. 
Ganesh, R., Robinson, K., Chu, L., Kucsmas, \& D., Reed, G. (1999). Reductive Precipitation of Uranium by Desulfovibrio Desulfuricans: Evaluation of Co contaminant Effects and Selective Removal. Water Research, 33 (16), 3447-3458.

Genschow, E., Hegemann, W., \& Maschke, C. (1996). Biological Sulfate Removal from Tannery Wastewater in a Two-Stage Anaerobic Treatment. Water Research, 30 (9), 2072-2078.

Gundry, M.J.. Henry. J.G., \& Prasad, D. (1990). Treating Electroplating Wastewater Using an Anaerobic Filter. $f f^{\text {th }}$ Purdue University Industrial Waste Conference Proceceding.'.270-285

Hao, O.J. Chen. J M. Huang, L., \& Buglass, R.L. (1996). Sulfate-Reducing Bacteria. Critical Revit'u s III Eimironmental Science and Technology, 26 (1), 155-187.

Harada, H., Uemura, S., \& Momonoi, K. (1994). Interaction Between Sulfate-Reducing Bacteria and Methane-Producing Bacteria in UASB Reactors Fed with Low Strength Wastes Containing Different Levels of Sulfate. Water Research, 28 (2), 355-367.

Hilton, B.L., \& Oleszkiewicz, J.A. (1988). Sulfide-induced Inhibition of Anaerobic Digestion. Journal of Environmental Engineering, 114, 1277. 
Isa, Z., Grusenmeyer, S., \& Verstraete, W. (1986a). Sulfate Reduction Relative to Methane Production in High-rate Anaerobic Digestion: Microbiological Aspects. Applied Environmental Microbiology, 51, 580.

Isa, Z., Grusenmeyer, S., \& Verstraete, W. (1986b). Sulfate Reduction Relative to Methane Production in High-rate Anaerobic Digestion: Technical Aspects. Applied Environmental Microbiology, 51, 572.

Jeffery, G.H., Bassett, J., Mendham, J., Denney, R.C. (1989). Vogel's: Textbook of Quantitative Chemical Analysis $\left(5^{\text {th }}\right.$ edition). New York, U.S.: Longman Scientific \& Technical.

Karhadkar, P.P., Audic, J-M., Faup, G.M., \& Khanna, P. (1987). Sulfide and Sulfate Inhibition of Methanogenesis. Water Research, 21 (9), 1061-1066.

Lyew, D., Knowles, R. \& Sheppard, J. (1994). The Biological Treatment of Acid Mine Drainage under Continuous Flow Conditions in a Reactor. Transactions of the Institution of Chemical Engineers, Part B, 72 (1), 42-47.

Maillacheruvu, K.Y., \& Parkin, G.F. (1996). Kinetics of Growth, Substrate Utilization and Sulfide Toxicity for Propionate, Acetate, and Hydrogen Utilizers in Anaerobic Systems. Water Environment Research, 68, 1099-1 106. 
McArdle, J.L., Arozarena, M.M., Gallagher, W.E. (1988). Treatment of Hazardous Waste Leachate: Unit Operations and Costs. New Jersey, U.S.: Noyes Data Corporation.

McCartney, D.M., Marstaller, T., Heinrichs, D.M., \& Oleszkiewicz, J.A. (1990). Sulfide Inhibition of Propionate Utilization in Anaerobic Treatment of Lactate and Acetate. $4 f^{\text {th }}$ Purdue University Industrial Waste Conference Proceedings, 265-270.

McCartney, D.M. and Oleszkiewicz, J.A. (1993). Competition between Methanogens and Sulfate Reducers: Effect of COD: Sulfate Ratio and Acclimation. Water Environmemt Research, 65 (5), 655-664.

McCarty, P.L., Beck, L., Amant, P.S. (1969). Biological Denitrification of Wastewaters by Addition of Organic Materials. $24^{\text {th }}$ Purdue University Industrial Waste Conference Proceedings, 1271-1285.

Mizuno, O., Li, Y., \& Noike, T. (1994). Effects of Sulfate Concentration and Sludge Retention Time on the Interaction between Methane Production and Sulfate Reduction for Butyrate. Water, Science and Technology, 30 (8), 45-54.

Mizuno, O., Takagi, H., \& Noike, T. (1998a). Biological Sulfate Removal in an Acidogenic Bioreactor with an Ultrafiltration Membrane System. Water, Science and Technology, 38 (4-5), 513-520. 
Mizuno, O., Li, Y.Y., \& Noike, T. (1998b). The Behavior of Sulfate-Reducing Bacteria in Acidogenic Phase of Anaerobic Digestion. Water Research, 32 (5), 1626-1634.

Omil, F., Lens, P., Visser, A., Hulshoff Pol, L.W., \& Lettinga, G. (1997). Long-Term Competition between Sulfate Reducing and Methanogenic Bacteria in UASB Reactors Treating Volatile Fatty Acids. Biotechnology and Bioengineering, 57 (6), 676-685.

Okabe, S., \& Characklis, W.G. (1991). Effects of Temperature and Phosphorous Concentration on Microbial Sulfate Reduction by Desulfovibrio Desulfuricans. Biotechnolegn and Bucongineering, 39 (10), 1031-1042.

Okabe. S . Nielsen. P H . \& Characklis, W.G. (1992). Factors Affecting Microbial Sulfate Reduction by Desulfwibrio Desulfuricans in Continuous Culture: Limiting Nutrients and Sulfide Concentration Bıotechmology and Bioengineering, 40, 725-734.

Okabe, S., Nielsen. P.H., Jones, W.L., \& Characklis, W.G. (1995). Sulfide Product Inhibition of Desulfovibrio Desulfuricans in Batch and Continuous Cultures. Water Research, 29 (2), 571-578.

Peavy, H.S., Rowe, D.R., Tchobanoglous, G. (1985). Environmental Engineering. Singapore: McGraw-Hill International Editions. 
Perry, K.A. (1995). Sulfate-Reducing Bacteria and Immobilization of Metals. Marine Georesources and Geotechnology, 13, 33-39.

Polprasert, C., \& Haas, C.N. (1995). Effect of Sulfate on Anaerobic Processes Fed with Dual Substrates. Water, Science and Technology, 31 (9), 101-107.

Postgate, J.R. (1984). The Sulfate Reducing Bacteria (2 ${ }^{\text {nd }}$ Ed.). Cambridge, U.K.: Cambridge University Press.

Reis, M.A.M., Almeida, J.S., Lemos, P.C., \& Carrondo, M.J.T. (1992). Effect of Hydrogen Sulfide on Growth of Sulfate Reducing Bacteria. Biotechnology and Bioengineering. 40. 593-600.

Rinzema, A. \& Letunģa. G (1988). The Effect of Sulfide on the Anaerobic Degradation of Propionate I:mrommental Technology Lectures, 9, 83.

Rivera, A.L I Jusi, Heavy Metal Removal in a Packed-Bed Anaerobic Upflow (ANFLOW) Bioreactor . Imurnal of Water Pollution Control Federation, 55 (12), 14501456.

Singh, K.S.. Harada. H. \& Viraraghavan, T. (1996). Low-Strength Wastewater Treatment by a LASB Reactor. Bioresource Technology, 55, 187-194. 
Song, Y., Piak, B., Shin, H., \& La, S. (1998). Influence of Electron Donor and Toxic Materials on the Activity of Sulfate Reducing Bacteria for the Treatment of Electroplating Wastewater. Water, Science and Technology, 38 (4-5), 187-194.

Speece, R.E. (1996). Anaerobic Biotechnology for Industrial Wastewaters. Nashville, U.S.: Archae Press.

U.S. Environmental Protection Agency. (1985). Handbook: Remedial Action at Waste Disposal Sites (Revised). EPA/625/6-85/006.

Visser, A., Gao, Y., \& Lettinga, G. (1993). Effects of Short-Term Temperature Increases on the Mesophilic Anaerobic Breakdown of Sulfate Containing Synthetic Wastewater. Water Research, 27 (4), 541-550.

Wijaya, S. (1993). Optimization of Dissolved Heavy Metals Removal using Sulfate Reducing Bacteria. M.A.Sc. Thesis, University of Windsor, Windsor, Ont., Canada. 162p.

Yamaguchi, T., Harada, H., Hisano, T., Yamazaki, S., \& Tseng, I. (1999). Process Behavior of UASB Reactor Treating a Wastewater Containing High Strength Sulfate. Water Research, 33 (14), $3182-3190$.

Yoda, M., Kitagawa, M., \& Miyaji, Y. (1987). Long term Competition between Sulfate Reducing and Methane Producing Bacteria in Anaerobic Biofilm. Water Research, 21, 1547. 


\section{APPENDIX A}

\section{CALIBRATION CURVES}

The following calibration curves were prepared during this study.

\section{A.l Pump Calibration}

For substrate pumping during the continuous mode operation of the upflow anaerobic reactors, two peristaltic pumps were used. These were calibrated every week in order to control any fluctuations in the flow rate. The calibration was done by measuring the flow rate at different pump controller settings and plotting the flow rate vs the setting. Figures A. 1 and A. 2 show typical calibration curves. 


\section{Controller 1}

(one head for Reactor III)

$\begin{array}{cc}\text { Setting } & \begin{array}{c}\text { Flow } \\ \text { mL/min }\end{array} \\ 0 & 3 \\ 1 & 14 \\ 2 & 30 \\ 3 & 52 \\ 4 & 69 \\ 5 & 86 \\ 6 & 108 \\ 7 & 130 \\ 8 & 150 \\ 9 & 164 \\ 10 & 168\end{array}$

\section{Controller 2}

(two heads for Reactors I and (I)

$\begin{array}{cc}\text { Setting } & \begin{array}{c}\text { Flon } \\ \text { mL/min }\end{array} \\ 0 & 15 \\ 1 & 14 \\ 2 & 31 \\ 3 & 40 \\ 4 & 60 \\ 5 & 87 \\ 6 & 108 \\ 7 & 120 \\ 8 & 144 \\ 9 & 162 \\ 10 & 170\end{array}$

Figure A.1 Pump Calibration Curve. Pump 1.

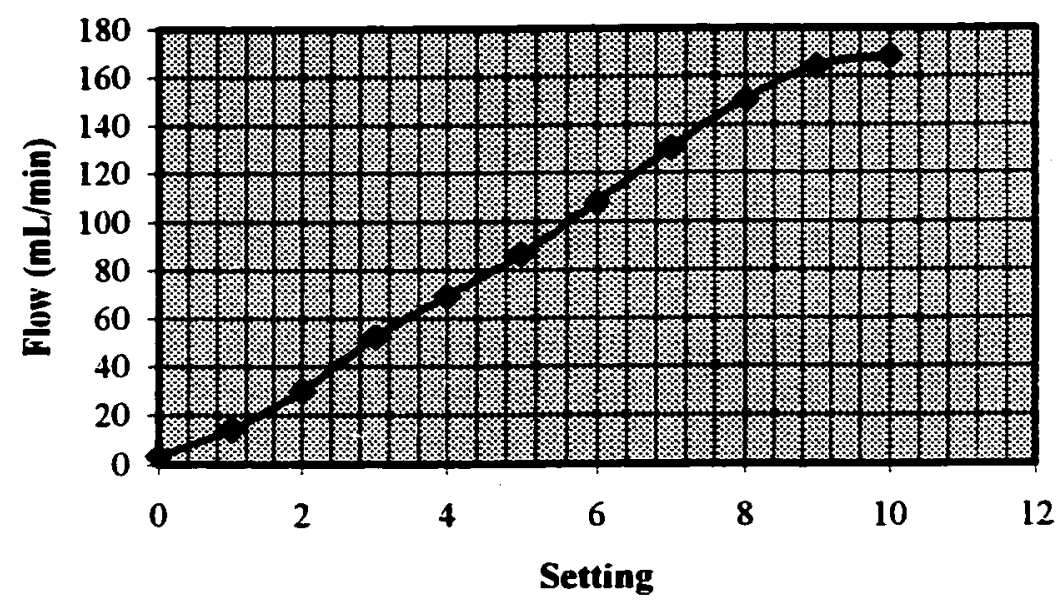

Figure A.2 Pump Calibration Curve. Pump 2.

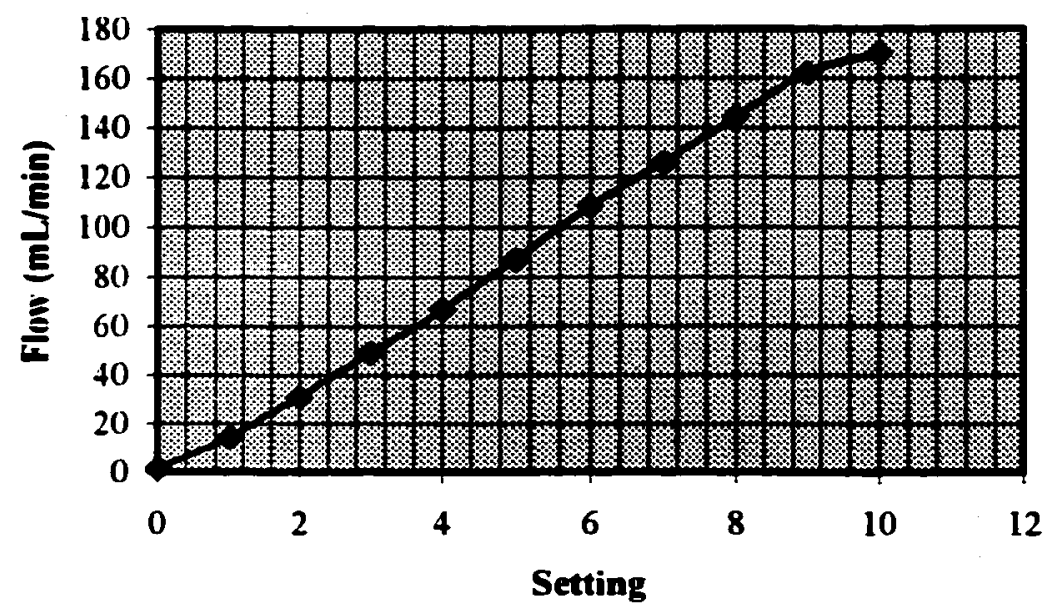




\section{A.2 Sulfate Calibration Curve}

Sulfate was analyzed according to the Standard Turbidimetric Method $4500-\mathrm{SO}_{4}{ }^{2-} \mathrm{E}$ (APHA, 1995). In order to determine the $\mathrm{SO}_{4}{ }^{2-}$ concentration, the NTU turbidity reading was compared with a standard curve prepared previously for different concentrations of standard sulfate solutions. The standard curve was prepared according to the Standard Methods (APHA, 1995) and is shown in Figure A.3. The equation obtained from the linear fitting of the points was used to calculate the sulfate concentration, $x$, based on the NTU, y, reading. The sulfate calibration curve was updated every two weeks or when a new batch of analyses was performed.

Figure A.3 Sulfate Calibration Curve

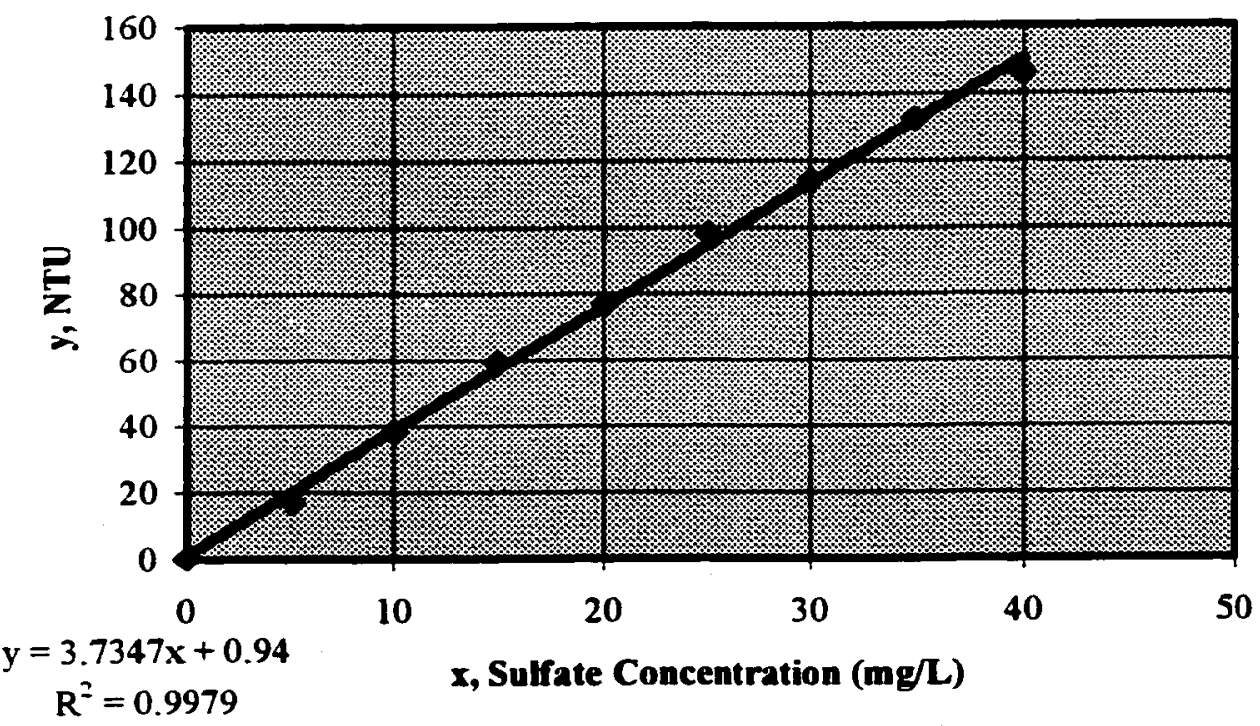




\section{APPENDIX B}

DATA

\section{B.1 Phase I}

Table B.1 Sulfide Production During Phase I (2 L Batch Reactors)

\begin{tabular}{|c|c|c|c|}
\hline Time (days) & \multicolumn{3}{|c|}{ SuIfde Concentration (mg) } \\
\hline & Reactor I & Reactor II & Reactor III \\
\hline 5 & 63 & 41 & 18 \\
\hline 10 & 78 & 79 & 57 \\
\hline 15 & 75 & 66 & 57 \\
\hline 20 & 24 & 35 & 54 \\
\hline 26 & 72 & 50 & 54 \\
\hline 32 & 80 & 76 & 88 \\
\hline 38 & 95 & 98 & 123 \\
\hline 46 & 123 & 130 & 123 \\
\hline 56 & 99 & 114 & 84 \\
\hline 63 & 100 & 115 & 90 \\
\hline
\end{tabular}

Reactor l. Packed. Deionized water for dilution.

Reactor II. Non-packed. Deionized water for dilution.

Reactor III. Non-packed. Tap water for dilution. 
Table B.2 ORP Progression During Phase I (2 L Batch Reactors)

\begin{tabular}{|c|c|c|c|}
\hline Time (days) & & ORP(mV) & \\
\hline & Reactor I & Reactor II & Reactor III \\
\hline 5 & $-366\left(25^{\circ} \mathrm{C}\right)$ & $-345\left(25^{\circ} \mathrm{C}\right)$ & $-351\left(25^{\circ} \mathrm{C}\right)$ \\
\hline 10 & $-304\left(25^{\circ} \mathrm{C}\right)$ & $-314\left(25^{\circ} \mathrm{C}\right)$ & $-295\left(25^{\circ} \mathrm{C}\right)$ \\
\hline 15 & $-335\left(23^{\circ} \mathrm{C}\right)$ & $-323\left(23^{\circ} \mathrm{C}\right)$ & $-308\left(20^{\circ} \mathrm{C}\right)$ \\
\hline 20 & $-370\left(19^{\circ} \mathrm{C}\right)$ & $-371\left(20^{\circ} \mathrm{C}\right)$ & $-359\left(19^{\circ} \mathrm{C}\right)$ \\
\hline 26 & $-367\left(25^{\circ} \mathrm{C}\right)$ & $-375\left(24^{\circ} \mathrm{C}\right)$ & $-371\left(25^{\circ} \mathrm{C}\right)$ \\
\hline 32 & $-372\left(20^{\circ} \mathrm{C}\right)$ & $-375\left(19^{\circ} \mathrm{C}\right)$ & $-372\left(20^{\circ} \mathrm{C}\right)$ \\
\hline 38 & $-381\left(22^{\circ} \mathrm{C}\right)$ & $-381\left(23^{\circ} \mathrm{C}\right)$ & $-381\left(22^{\circ} \mathrm{C}\right)$ \\
\hline 46 & $-382\left(21^{\circ} \mathrm{C}\right)$ & $-383\left(19^{\circ} \mathrm{C}\right)$ & $-383\left(19^{\circ} \mathrm{C}\right)$ \\
\hline 56 & $-379\left(19^{\circ} \mathrm{C}\right)$ & $-381\left(22^{\circ} \mathrm{C}\right)$ & $-379\left(22^{\circ} \mathrm{C}\right)$ \\
\hline 63 & $-380\left(20^{\circ} \mathrm{C}\right)$ & $-380\left(20^{\circ} \mathrm{C}\right)$ & $-380\left(19^{\circ} \mathrm{C}\right)$ \\
\hline
\end{tabular}

Table B.3 pH Progression During Phase I (2 L Batch Reactors)

\begin{tabular}{|c|c|c|c|}
\hline Time (days) & \multicolumn{3}{|c|}{$\mathbf{p H}$} \\
\hline & Reactor I & Reactor I & Reactor III \\
\hline 5 & 7.0 & 7.0 & 7.0 \\
\hline 10 & 7.0 & 7.0 & 6.7 \\
\hline 15 & 6.5 & 7.0 & 6.5 \\
\hline 20 & 7.0 & 7.0 & 7.0 \\
\hline 26 & 7.0 & 7.0 & 6.7 \\
\hline 32 & 6.8 & 7.1 & 6.9 \\
\hline 38 & 7.0 & 7.0 & 7.0 \\
\hline 46 & 7.0 & 7.0 & 7.0 \\
\hline 56 & 6.9 & 7.1 & 6.6 \\
\hline 63 & 6.5 & 7.0 & 6.5 \\
\hline
\end{tabular}




\section{B.2 Phase II}

Table B.4 Sulfide Production During Phase II ( ${ }^{\text {st }}$ and $2^{\text {nd }}$ Sequences)

\begin{tabular}{|c|c|c|c|}
\hline Time (days) & \multicolumn{3}{|c|}{ Süride Concentration (mg/) } \\
\hline & Reactor I & Reactor I & Reactor III \\
\hline 0 & 0 & 0 & 0 \\
\hline 7 & 32 & 12 & 2 \\
\hline 14 & 35 & 21 & 3 \\
\hline 21 & 32 & 5 & 8 \\
\hline 28 & 67 & 47 & 38 \\
\hline 32 & 88 & 70 & 81 \\
\hline 36 & 97 & 67 & 75 \\
\hline 40 & 78 & 66 & 71 \\
\hline 44 & 81 & 47 & 60 \\
\hline 48 & 88 & 50 & 51 \\
\hline 52 & 84 & 72 & 62 \\
\hline 56 & 85 & 80 & 66 \\
\hline
\end{tabular}

Reactor I. Packed.

Reactor II. Non-packed.

Reactor III Packed. Packing material removal on Day 44. 
Table B.5 ORP Progression During Phase II (1 $1^{\text {st }}$ and $2^{\text {nd }}$ Sequences)

\begin{tabular}{|c|c|c|c|}
\hline Time (day) & Rere & ORP (mV) & Reactor II \\
\hline & Reactor I & Reactor II & $-290\left(25^{\circ} \mathrm{C}\right)$ \\
\hline 7 & $-328\left(25^{\circ} \mathrm{C}\right)$ & $-328\left(25^{\circ} \mathrm{C}\right)$ & $-283\left(20^{\circ} \mathrm{C}\right)$ \\
\hline 14 & $-336\left(20^{\circ} \mathrm{C}\right)$ & $-278\left(20^{\circ} \mathrm{C}\right)$ & $-288\left(19^{\circ} \mathrm{C}\right)$ \\
\hline 21 & $-329\left(20^{\circ} \mathrm{C}\right)$ & $-301\left(19^{\circ} \mathrm{C}\right)$ & $-314\left(19^{\circ} \mathrm{C}\right)$ \\
\hline 28 & $-326\left(19^{\circ} \mathrm{C}\right)$ & $-297\left(18^{\circ} \mathrm{C}\right)$ & $-319\left(19^{\circ} \mathrm{C}\right)$ \\
\hline 32 & $-327\left(19^{\circ} \mathrm{C}\right)$ & $-318\left(19^{\circ} \mathrm{C}\right)$ & $-324\left(23^{\circ} \mathrm{C}\right)$ \\
\hline 36 & $-315\left(23^{\circ} \mathrm{C}\right)$ & $-323\left(23^{\circ} \mathrm{C}\right)$ & $-352\left(19^{\circ} \mathrm{C}\right)$ \\
\hline 40 & $-326\left(19^{\circ} \mathrm{C}\right)$ & $-322\left(19^{\circ} \mathrm{C}\right)$ & $-350\left(19^{\circ} \mathrm{C}\right)$ \\
\hline 44 & $-325\left(19^{\circ} \mathrm{C}\right)$ & $-299\left(19^{\circ} \mathrm{C}\right)$ & $-342\left(18^{\circ} \mathrm{C}\right)$ \\
\hline 48 & $-343\left(18^{\circ} \mathrm{C}\right)$ & $-288\left(19^{\circ} \mathrm{C}\right)$ & $-345\left(19^{\circ} \mathrm{C}\right)$ \\
\hline 52 & $-350\left(19^{\circ} \mathrm{C}\right)$ & $-292\left(19^{\circ} \mathrm{C}\right)$ & $-353\left(18^{\circ} \mathrm{C}\right)$ \\
\hline 56 & $-351\left(19^{\circ} \mathrm{C}\right)$ & $-363\left(18^{\circ} \mathrm{C}\right)$ & \\
\hline
\end{tabular}

Table B.6 pH Progression During Phase $I$ (1 $\left(^{\text {st }}\right.$ and $2^{\text {nd }}$ Sequences)

\begin{tabular}{|c|c|c|c|}
\hline Time (days) & Reactor I & Reactor I & Reactor II \\
\hline & 7.1 & 7.1 & 6.5 \\
\hline 0 & 6.8 & 6.7 & 6.7 \\
\hline 7 & 6.9 & 7.0 & 6.8 \\
\hline 14 & 7.0 & 6.5 & 6.8 \\
\hline 21 & 7.0 & 6.7 & 6.8 \\
\hline 28 & 7.0 & 6.8 & 7.0 \\
\hline 32 & 7.0 & 6.7 & 7.0 \\
\hline 36 & 7.0 & 6.5 & 7.0 \\
\hline 40 & 7.0 & 7.0 & 7.0 \\
\hline 44 & 7.0 & 7.0 & 7.0 \\
\hline 48 & 7.0 & 6.0 & 7.0 \\
\hline 52 & 7.0 & 7.0 & 7.0 \\
\hline 56 & & & \\
\hline
\end{tabular}


Table B.7 Sulfide Production During Phase II (3rd and $4^{\text {th }}$ Sequences)

\begin{tabular}{|c|c|c|c|}
\hline \multirow{2}{*}{ Time (days) } & \multicolumn{3}{|c|}{ Sulrde Concentration (mg/) } \\
\hline & Reactor I & Reactor II & Reactor III \\
\hline 60 & 125 & 74 & 113 \\
\hline 64 & 120 & 32 & 45 \\
\hline 69 & 141 & 82 & 73 \\
\hline 72 & 139 & 89 & 69 \\
\hline 76 & 129 & 75 & 65 \\
\hline 88 & 136 & 89 & 83 \\
\hline 92 & 144 & 101 & 110 \\
\hline 96 & 170 & 107 & 119 \\
\hline 108 & 187 & 114 & 142 \\
\hline 114 & 152 & 102 & 105 \\
\hline 117 & 173 & 118 & 79 \\
\hline 122 & 184 & 124 & 133 \\
\hline 125 & 200 & 151 & 148 \\
\hline 128 & 208 & 158 & 154 \\
\hline 149 & 164 & 185 & 169 \\
\hline 154 & 154 & 177 & 138 \\
\hline
\end{tabular}

Reactor I. Packed.

Reactor II Non-packed.

Reactor III Non-packed. 
Table B.8 VSS Production During Phase II (3 $3^{\text {rd }}$ and $4^{\text {th }}$ Sequences)

\begin{tabular}{|c|c|c|c|}
\hline Time (days) & \multicolumn{3}{|c|}{ VSS Concentration (mg) } \\
\hline & Reactor I & Reactor II & Reactor II \\
\hline 60 & 54 & 31 & 81 \\
\hline 64 & 21 & 17 & 85 \\
\hline 69 & 21 & 17 & 84 \\
\hline 92 & 11 & 22 & 55 \\
\hline 96 & 12 & 25 & 50 \\
\hline 108 & 12 & 33 & 56 \\
\hline 114 & 12 & 34 & 64 \\
\hline 117 & 14 & 48 & 81 \\
\hline 122 & 15 & 63 & 92 \\
\hline 125 & 26 & 74 & 99 \\
\hline 128 & 28 & 82 & 108 \\
\hline 149 & 14 & 48 & 94 \\
\hline 154 & 11 & 38 & 62 \\
\hline 160 & 11 & 28 & 64 \\
\hline
\end{tabular}


Table B.9 pH Progression During Phase $\mathrm{I}\left(3^{\text {rd }}\right.$ and $4^{\text {th }}$ Sequences)

\begin{tabular}{|c|c|c|c|}
\hline Time (days) & Reactor I & Reactor I & Reactor II \\
\hline & Rer & 6.4 \\
\hline 60 & 6.4 & 6.2 & 7.0 \\
\hline 64 & 7.0 & 7.0 & 6.2 \\
\hline 76 & 6.5 & 6.3 & 6.1 \\
\hline 88 & 6.1 & 6.2 & 6.0 \\
\hline 92 & 6.2 & 6.2 & 6.3 \\
\hline 96 & 6.4 & 6.4 & 6.2 \\
\hline 108 & 6.1 & 6.4 & 6.0 \\
\hline 114 & 6.1 & 6.3 & 5.9 \\
\hline 117 & 5.7 & 6.2 & 5.9 \\
\hline 122 & 5.5 & 6.0 & 6.0 \\
\hline 125 & 5.8 & 6.0 & 6.0 \\
\hline 128 & 5.9 & 6.0 & 5.0 \\
\hline 149 & 5.0 & 5.1 & 5.1 \\
\hline 154 & 5.3 & 5.3 & 5.0 \\
\hline 160 & 5.0 & 5.0 & \\
\hline
\end{tabular}

Table B.10 Sulfide Production During Phase II (Consecutive)

\begin{tabular}{|c|c|c|c|}
\hline Time (day) & \multicolumn{3}{|c|}{ Sulfide Concentration (mg/M) } \\
\hline & Reactor I & Reactor I & Reactor III \\
\hline 0 & 144 & 101 & 110 \\
\hline 1 & 147 & 95 & 91 \\
\hline 2 & 150 & 99 & 99 \\
\hline 3 & 158 & 101 & 103 \\
\hline 4 & 170 & 107 & 119 \\
\hline
\end{tabular}


Table B.11 VSS Production During Phase II (Consecutive)

\begin{tabular}{|c|c|c|c|}
\hline Time (days) & \multicolumn{3}{|c|}{ VSS Concentration (mg/M) } \\
\hline & Reactor I & Reactor I & Reactor II \\
\hline 0 & 11 & 22 & 55 \\
\hline 1 & 15 & 22 & 51 \\
\hline 2 & 16 & 25 & 48 \\
\hline 3 & 14 & 24 & 48 \\
\hline 4 & 12 & 25 & 50 \\
\hline
\end{tabular}

Table B.12 ORP Progression During Phase II (Consecutive)

\begin{tabular}{|c|c|c|c|}
\hline Time (days) & 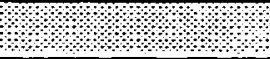 & ORP(mV) & \\
\hline & Reactor I & Reactor II & Reactor III \\
\hline 0 & $-346\left(23^{\circ} \mathrm{C}\right)$ & $-309\left(23^{\circ} \mathrm{C}\right)$ & $-337\left(24^{\circ} \mathrm{C}\right)$ \\
\hline 1 & $-362\left(23^{\circ} \mathrm{C}\right)$ & $-312\left(23^{\circ} \mathrm{C}\right)$ & $-340\left(23^{\circ} \mathrm{C}\right)$ \\
\hline 2 & $-363\left(22^{\circ} \mathrm{C}\right)$ & $-328\left(22^{\circ} \mathrm{C}\right)$ & $-300\left(23^{\circ} \mathrm{C}\right)$ \\
\hline 3 & $-341\left(22^{\circ} \mathrm{C}\right)$ & $-301\left(22^{\circ} \mathrm{C}\right)$ & $-307\left(22^{\circ} \mathrm{C}\right)$ \\
\hline 4 & $-350\left(19^{\circ} \mathrm{C}\right)$ & $-315\left(20^{\circ} \mathrm{C}\right)$ & $-287\left(20^{\circ} \mathrm{C}\right)$ \\
\hline
\end{tabular}

Table B.13 pH Progression During Phase II (Consecutive)

\begin{tabular}{|c|c|c|c|}
\hline Time (days) & W.t. & $\mathrm{PH}$ & -2 \\
\hline & Reactor I & Reactor $\mathbf{U}$ & Reactor III \\
\hline 0 & 6.2 & 6.2 & 6.0 \\
\hline 1 & 6.1 & 6.2 & 6.1 \\
\hline 2 & 6.1 & 6.2 & 6.2 \\
\hline 3 & 6.2 & 6.3 & 6.2 \\
\hline 4 & $\overline{6.4}$ & 6.4 & 6.3 \\
\hline
\end{tabular}


Table B14. VSS and Sulfide Relation for Reactor I (New Substrate Formulation)

\begin{tabular}{|c|c|}
\hline VSS (mg/h) & Suinde $(\mathbf{m g})$ \\
\hline 13 & 154 \\
\hline 16 & 175 \\
\hline 18 & 185 \\
\hline 25 & 202 \\
\hline 29 & 209 \\
\hline
\end{tabular}

Table B15. ISS and Sulfide Relation for Reactor II (New Substrate Formulation)

\begin{tabular}{|c|c|}
\hline VSS (mg/t) & Sulme (mg/W) \\
\hline 35 & 104 \\
\hline 46 & 110 \\
\hline 61 & 123 \\
\hline 75 & 152 \\
\hline 84 & 159 \\
\hline
\end{tabular}

Table B.16 VSS and Sulfide Relation for Reactor III (New Substrate Formulation)

\begin{tabular}{|c|c|}
\hline VSS (mg/L) & Suirde (mg/W) \\
\hline 72 & 105 \\
\hline 84 & 112 \\
\hline 90 & 130 \\
\hline 104 & 150 \\
\hline 112 & 155 \\
\hline
\end{tabular}




\section{B.3 Phase III}

Table B.17 Emuent and First Port Sulfide Concentrations. Set 1

\begin{tabular}{|c|c|c|c|c|c|c|c|}
\hline \multicolumn{4}{|c|}{ 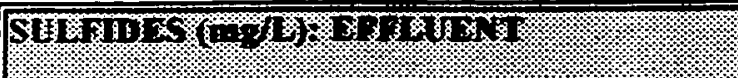 } & \multicolumn{4}{|c|}{ 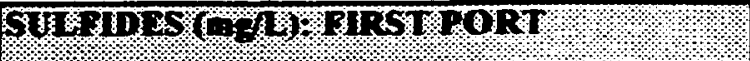 } \\
\hline $\begin{array}{l}\text { Time } \\
\text { (d) }\end{array}$ & $\begin{array}{c}\text { Reactor I } \\
(50 \mathrm{~h})\end{array}$ & $\begin{array}{c}\text { Reactor II } \\
(50 \mathrm{~h})\end{array}$ & $\begin{array}{c}\text { Reactor III } \\
(30 \mathrm{~h})\end{array}$ & $\begin{array}{l}\text { Time } \\
\text { (d) }\end{array}$ & $\begin{array}{c}\text { Reactor I } \\
(50 \mathrm{~h})\end{array}$ & $\begin{array}{c}\text { Reactor II } \\
(50 \mathrm{~h})\end{array}$ & $\begin{array}{c}\text { Reactor III } \\
(30 \mathrm{~h})\end{array}$ \\
\hline 0 & 144 & 102 & 164 & 0 & 137 & 72 & 160 \\
\hline 2 & 106 & 61 & 56 & 2 & 46 & 68 & 56 \\
\hline 4 & 31 & 38 & 15 & 4 & 4 & 46 & 41 \\
\hline 7 & 32 & +7 & 32 & 7 & 50 & 68 & 52 \\
\hline 9 & 54 & 77 & 72 & 9 & 70 & 59 & 55 \\
\hline 11 & 56 & 78 & 154 & 11 & 68 & +9 & 82 \\
\hline 13 & 83 & 92 & 170 & 13 & 114 & 101 & 151 \\
\hline 15 & 102 & 114 & 181 & 15 & 150 & 114 & 167 \\
\hline 17 & 125 & 135 & 174 & 17 & 154 & 104 & 163 \\
\hline 19 & 157 & 132 & 192 & 19 & 165 & 119 & 190 \\
\hline 21 & 155 & $1+1$ & 176 & 21 & 165 & $1+4$ & 190 \\
\hline 23 & $1+2$ & 130 & 186 & 23 & 153 & 121 & 195 \\
\hline 26 & $1+2$ & 128 & 180 & 26 & 152 & 116 & 149 \\
\hline 28 & 142 & 146 & 174 & 28 & 160 & 130 & 155 \\
\hline $\begin{array}{c}\text { average } \\
\text { last } 3 \text { valucis }\end{array}$ & 142 & 1.35 & 180 & $\begin{array}{c}\text { average } \\
\text { lutst i values }\end{array}$ & 155 & 122 & 166 \\
\hline
\end{tabular}

Tahle B.18 Emuent and First Port VSS Concentrations. Set 1

\begin{tabular}{|c|c|c|c|c|c|c|c|}
\hline \multicolumn{4}{|c|}{ WSS(mg/L): EFFLUENT } & \multicolumn{4}{|c|}{ WSOHOH } \\
\hline $\begin{array}{l}\text { Time } \\
\text { (d) }\end{array}$ & $\begin{array}{l}R=1-1111 \\
1511 f_{11}\end{array}$ & $\begin{array}{l}\text { Rsistor II } \\
\text { (50 h) }\end{array}$ & $\begin{array}{c}\text { Reactor III } \\
(30 \mathrm{~h})\end{array}$ & $\begin{array}{l}\text { Time } \\
\text { (d) }\end{array}$ & $\begin{array}{l}\text { Reactor I } \\
(50 \mathrm{~h})\end{array}$ & $\begin{array}{c}\text { Reactor II } \\
(50 \mathrm{~h})\end{array}$ & $\begin{array}{c}\text { Reactor III } \\
(30 \mathrm{~h})\end{array}$ \\
\hline (1) & $1-$ & 45 & 84 & 0 & 7 & 36 & 52 \\
\hline 2 & 16 & $4 x$ & 10 & 2 & 10 & 36 & 25 \\
\hline 4 & st. & 17 & 20 & 4 & 57 & 29 & 29 \\
\hline 7 & 24 & +3 & 52 & 7 & 23 & 54 & 34 \\
\hline 9 & $i x$ & 27 & 53 & 9 & 31 & 29 & 24 \\
\hline 11 & $\because$ & 40 & 22 & 11 & 21 & 19 & 16 \\
\hline 13 & 40 & 1,0 & 27 & 13 & 50 & 68 & 40 \\
\hline 15 & $6 !$ & 53 & 30 & 15 & 57 & 48 & 27 \\
\hline 17 & $d 4$ & +1 & 25 & 17 & 62 & 63 & 26 \\
\hline 19 & 511 & 53 & 19 & 19 & 58 & 89 & 24 \\
\hline 21 & $1: 2$ & +4 & 18 & 21 & 89 & 54 & 18 \\
\hline 23 & 41 & 4y & 15 & 23 & 90 & 63 & 23 \\
\hline 26 & $s_{1}$, & 45 & 19 & 26 & 67 & 50 & 46 \\
\hline 28 & $x / 1$ & 川1 & +1 & 28 & 86 & 81 & 58 \\
\hline $\begin{array}{c}\text { average } \\
\text { last } 3 \text { valuex }\end{array}$ & $1,:$ & 62 & 25 & $\begin{array}{c}\text { average } \\
\text { last } 3 \text { values }\end{array}$ & 81 & 65 & +2 \\
\hline
\end{tabular}


Table B.19 Emuent and First Port pH Values. Set 1

\begin{tabular}{|c|c|c|c|c|c|c|c|}
\hline \multicolumn{4}{|c|}{ 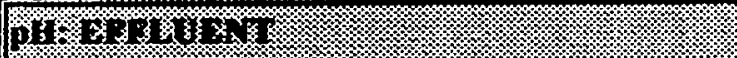 } & \multicolumn{4}{|c|}{ 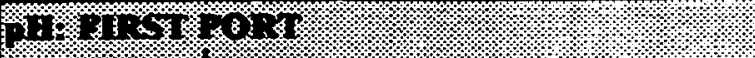 } \\
\hline $\begin{array}{l}\text { Time } \\
\text { (d) }\end{array}$ & $\begin{array}{c}\text { Reactor I } \\
(50 \mathrm{~h})\end{array}$ & $\begin{array}{l}\text { Reactor II } \\
(50 \mathrm{~h})\end{array}$ & $\begin{array}{c}\text { Reactor III } \\
(30 \mathrm{~h})\end{array}$ & $\begin{array}{l}\text { Time } \\
\text { (d) }\end{array}$ & $\begin{array}{c}\text { Reactor I } \\
(50 \mathrm{~h})\end{array}$ & $\begin{array}{c}\text { Reactor II } \\
(50 \mathrm{~h})\end{array}$ & $\begin{array}{l}\text { Reactor III } \\
(30 \mathrm{~h})\end{array}$ \\
\hline 0 & 6.3 & 6.4 & 5.7 & 0 & 6.3 & 6.2 & 6.2 \\
\hline 2 & 6.1 & 6.7 & 6.7 & 2 & 6.4 & 6.5 & 6.4 \\
\hline 4 & 6.2 & 6.8 & 6.3 & 4 & 5.7 & 5.8 & 6.3 \\
\hline 7 & 6.0 & 6.2 & 6.1 & 7 & 5.7 & 5.5 & 6.3 \\
\hline 9 & 6.1 & 6.5 & 6.3 & 9 & 6.0 & 6.4 & 6.4 \\
\hline 11 & 6.2 & 6.3 & 6.5 & 11 & 6.0 & 6.3 & 6.5 \\
\hline 13 & 6.0 & 6.1 & 6.4 & 13 & 5.8 & 6.1 & 6.4 \\
\hline 15 & 5.9 & 6.1 & 6.2 & 15 & 5.8 & 5.9 & 6.4 \\
\hline 17 & 5.9 & 6.0 & 6.4 & 17 & 5.7 & 6.0 & 6.4 \\
\hline 19 & 6.1 & 6.2 & 6.5 & 19 & 5.7 & 5.9 & 6.3 \\
\hline 21 & 5.9 & 6.0 & 6.5 & 21 & 5.6 & 5.6 & 6.2 \\
\hline 23 & 5.8 & 5.9 & 6.2 & 23 & 5.6 & 5.7 & 6.1 \\
\hline 26 & 5.9 & 6.1 & 6.1 & 26 & 5.6 & 6.0 & 5.9 \\
\hline 28 & 5.6 & 5.7 & 6.0 & 28 & 5.3 & 5.3 & 5.4 \\
\hline \begin{tabular}{|c|} 
average \\
Last 3 values
\end{tabular} & 5.8 & 5.9 & 6.1 & $\begin{array}{c}\text { average } \\
\text { last } 3 \text { values }\end{array}$ & 5.5 & 5.7 & 5.8 \\
\hline
\end{tabular}


Table B.20 Emuent ORP Values. Set 1

\begin{tabular}{|c|c|c|c|c|c|c|}
\hline \multicolumn{4}{|c|}{ 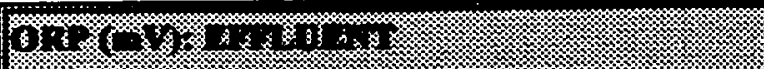 } & \multicolumn{3}{|c|}{ 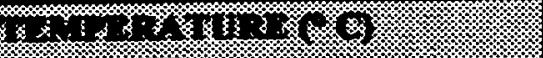 } \\
\hline $\begin{array}{l}\text { Time } \\
\text { (d) }\end{array}$ & $\begin{array}{c}\text { Reactor I } \\
(50 \mathrm{~h})\end{array}$ & $\begin{array}{c}\text { Reactor II } \\
(50 \mathrm{~h})\end{array}$ & $\begin{array}{c}\text { Reactor III } \\
(30 \mathrm{~h})\end{array}$ & $\begin{array}{c}\text { Reactor I } \\
(50 \mathrm{~h})\end{array}$ & $\begin{array}{c}\text { Reactor II } \\
(50 \mathrm{~h})\end{array}$ & $\begin{array}{c}\text { Reactor III } \\
(30 \mathrm{~h})\end{array}$ \\
\hline 0 & -322 & -314 & -345 & 19 & 19 & 19 \\
\hline 2 & -307 & -303 & -286 & 21 & 21 & 21 \\
\hline 4 & -230 & -278 & -230 & 22 & 22 & 22 \\
\hline 7 & -230 & -281 & -243 & 20 & 20 & 20 \\
\hline 9 & -250 & -289 & -266 & 20 & 20 & 20 \\
\hline 11 & -261 & -291 & -331 & 19 & 19 & 18 \\
\hline 13 & -271 & -289 & -347 & 20 & 20 & 20 \\
\hline 15 & -296 & -307 & -356 & 21 & 21 & 21 \\
\hline 17 & -303 & -311 & -365 & 19 & 19 & 19 \\
\hline 19 & -306 & -312 & -363 & 19 & 19 & 19 \\
\hline 21 & -308 & -315 & -366 & 19 & 19 & 19 \\
\hline 23 & -314 & -318 & -363 & 20 & 20 & 20 \\
\hline 26 & -303 & -314 & -342 & 18 & 18 & 19 \\
\hline 28 & -302 & -336 & -379 & 19 & 19 & 20 \\
\hline $\begin{array}{c}\text { average } \\
\text { last } 3 \text { values }\end{array}$ & -306 & -323 & -361 & 19 & 19 & 19 \\
\hline
\end{tabular}

Table B.21 First Port ORP Values. Set 1

\begin{tabular}{|c|c|c|c|c|c|c|}
\hline \multicolumn{4}{|c|}{ कAr } & \multicolumn{3}{|c|}{ 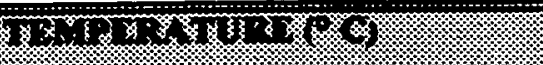 } \\
\hline $\begin{array}{l}\text { Time } \\
\text { (d) }\end{array}$ & $\begin{array}{c}\text { Reactor I } \\
(50 \mathrm{~h})\end{array}$ & $\begin{array}{c}\text { Reactor II } \\
(50 \mathrm{~h})\end{array}$ & $\begin{array}{c}\text { Reactor III } \\
(30 \mathrm{~h})\end{array}$ & $\begin{array}{c}\text { Reactor I } \\
(50 \mathrm{~h})\end{array}$ & $\begin{array}{c}\text { Reactor II } \\
(50 \mathrm{~h})\end{array}$ & $\begin{array}{l}\text { Reactor III } \\
(30 \mathrm{~h})\end{array}$ \\
\hline 0 & -324 & -316 & -348 & 19 & 19 & 19 \\
\hline 2 & -275 & -310 & -294 & 21 & 21 & 21 \\
\hline 4 & -232 & -285 & .223 & 22 & 22 & 22 \\
\hline 7 & -253 & -289 & -231 & 20 & 20 & 20 \\
\hline 9 & -266 & -288 & -282 & 20 & 20 & 20 \\
\hline 11 & -280 & -292 & -303 & 19 & 19 & 18 \\
\hline 13 & -281 & -309 & -331 & 20 & 20 & 20 \\
\hline 15 & -309 & -317 & -344 & 21 & 21 & 21 \\
\hline 17 & -314 & -317 & -349 & 20 & 20 & 20 \\
\hline 19 & -318 & -317 & -351 & 19 & 19 & 19 \\
\hline 21 & -320 & -323 & -354 & 20 & 20 & 20 \\
\hline 23 & -319 & -320 & -351 & 20 & 20 & 20 \\
\hline 26 & -307 & -317 & -348 & 18 & 19 & 19 \\
\hline 28 & -309 & -340 & -370 & 19 & 19 & 20 \\
\hline $\begin{array}{c}\text { average } \\
\text { last } 3 \text { values }\end{array}$ & -312 & -325 & -356 & 19 & 19 & 20 \\
\hline
\end{tabular}


Table B.22 Analyses along Reactors' Height During Steady State. Set 1

\begin{tabular}{|c|c|c|c|}
\hline \multicolumn{4}{|c|}{ 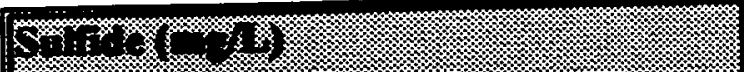 } \\
\hline $\begin{array}{c}\text { Sampling } \\
\text { Port }\end{array}$ & $\begin{array}{c}\text { Reactor I } \\
(50 \mathrm{~h})\end{array}$ & $\begin{array}{c}\text { Reactor II } \\
(50 \mathrm{~h})\end{array}$ & $\begin{array}{c}\text { Reactor III } \\
(30 \mathrm{~h})\end{array}$ \\
\hline effluent & 142 & 166 & 164 \\
\hline 3rd port & 160 & 207 & 187 \\
\hline 2nd port & 156 & 190 & 201 \\
\hline 1st port & 160 & 198 & 155 \\
\hline \multicolumn{4}{|c|}{ Hor. } \\
\hline \begin{tabular}{|c|} 
Sampling \\
Port
\end{tabular} & $\begin{array}{c}\text { Reactor I } \\
(50 \mathrm{~h})\end{array}$ & $\begin{array}{c}\text { Reactor II } \\
(50 \mathrm{~h})\end{array}$ & $\begin{array}{c}\text { Reactor III } \\
(30 \mathrm{~h})\end{array}$ \\
\hline effluent & 80 & 91 & 41 \\
\hline 3rd port & 83 & 61 & 46 \\
\hline 2nd port & 57 & 64 & 51 \\
\hline Ist port & 86 & 81 & 58 \\
\hline \multicolumn{4}{|l|}{$\mathrm{pH}$} \\
\hline $\begin{array}{c}\text { Sampling } \\
\text { Port }\end{array}$ & $\begin{array}{c}\text { Reactor I } \\
(50 \mathrm{~h}) \\
\end{array}$ & $\begin{array}{c}\text { Reactor II } \\
(50 \mathrm{~h})\end{array}$ & $\begin{array}{c}\text { Reactor III } \\
(30 \mathrm{~h})\end{array}$ \\
\hline cmuent & 5.6 & 5.7 & 6.0 \\
\hline ird por & 5.4 & 5.5 & 5.6 \\
\hline Ind pon & 5.3 & 5.5 & 5.3 \\
\hline Ist por & 5.3 & 5.3 & 5.4 \\
\hline \multicolumn{4}{|c|}{$\begin{array}{l}\operatorname{ORP}(\mathrm{g}) \\
\mathrm{T}(\mathrm{O})\end{array}$} \\
\hline $\begin{array}{c}\text { Simpling } \\
\text { Pon }\end{array}$ & $\begin{array}{c}\text { Reactor I } \\
(50 \mathrm{~h})\end{array}$ & $\begin{array}{c}\text { Reactor II } \\
(50 \mathrm{~h})\end{array}$ & $\begin{array}{c}\text { Reactor III } \\
(30 \mathrm{~h})\end{array}$ \\
\hline \multirow[t]{2}{*}{ emluent } & -302 & -336 & -379 \\
\hline & 19 & 19 & 20 \\
\hline \multirow[t]{2}{*}{ ind pon } & -311 & -338 & -375 \\
\hline & 19 & 19 & 20 \\
\hline \multirow[t]{2}{*}{ ind port } & -308 & -337 & -377 \\
\hline & 19 & 20 & 20 \\
\hline \multirow[t]{2}{*}{151 por } & -309 & -340 & -370 \\
\hline & 19 & 19 & 20 \\
\hline
\end{tabular}


Table B.23 Emuent and First Port Sulfide Concentrations. Set 2

\begin{tabular}{|c|c|c|c|c|c|c|c|}
\hline \multicolumn{4}{|c|}{ 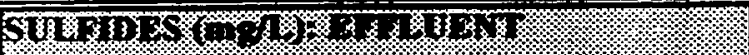 } & \multicolumn{4}{|c|}{ 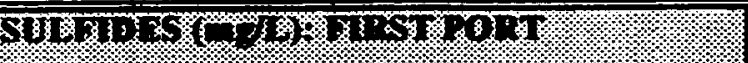 } \\
\hline $\begin{array}{l}\text { Time } \\
\text { (d) }\end{array}$ & $\begin{array}{c}\text { Reactor I } \\
(30 \mathrm{~h})\end{array}$ & $\begin{array}{c}\text { Reactor II } \\
(30 \mathrm{~h})\end{array}$ & $\begin{array}{c}\text { Reactor III } \\
(20 \mathrm{~h})\end{array}$ & $\begin{array}{l}\text { Time } \\
\text { (d) }\end{array}$ & $\begin{array}{c}\text { Reactor I } \\
(30 \mathrm{~h})\end{array}$ & $\begin{array}{c}\text { Reactor II } \\
(30 \mathrm{~h})\end{array}$ & $\begin{array}{c}\text { Reactor III } \\
(20 \mathrm{~h})\end{array}$ \\
\hline 0 & 163 & 173 & 137 & 0 & 148 & 161 & 159 \\
\hline 2 & 66 & 158 & 147 & 2 & 51 & 161 & 153 \\
\hline 4 & 103 & 170 & 146 & 4 & 105 & 177 & 137 \\
\hline 6 & 127 & 160 & 158 & 6 & 143 & 172 & 126 \\
\hline 8 & 155 & 190 & 140 & 8 & 144 & 181 & $9 y$ \\
\hline 10 & 178 & 190 & 167 & 10 & 156 & 185 & 118 \\
\hline 13 & 187 & 195 & 155 & 13 & 179 & 171 & 121 \\
\hline 15 & 186 & 193 & 166 & 15 & 181 & 187 & 110 \\
\hline 17 & 189 & 180 & 150 & 17 & 183 & 188 & 120 \\
\hline 20 & 190 & 185 & 160 & 20 & 186 & 187 & 130 \\
\hline $\begin{array}{c}\text { average } \\
\text { last } 3 \text { values }\end{array}$ & 188 & 186 & 159 & $\begin{array}{c}\text { average } \\
\text { last } 3 \text { values }\end{array}$ & 183 & 187 & 120 \\
\hline
\end{tabular}

Table B.24 Emuent and First Port VSS Concentrations. Set 2

\begin{tabular}{|c|c|c|c|c|c|c|c|}
\hline \multicolumn{4}{|c|}{ 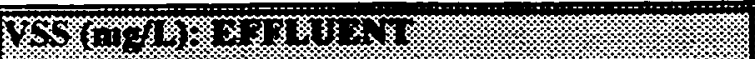 } & \multicolumn{4}{|c|}{ 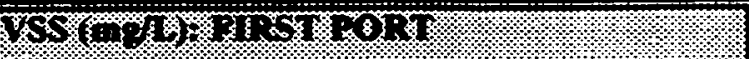 } \\
\hline $\begin{array}{l}\text { Time } \\
\text { (d) }\end{array}$ & $\begin{array}{l}\text { Reactor I } \\
(30 \mathrm{~h})\end{array}$ & $\begin{array}{l}\text { Reactor II } \\
(30 \mathrm{~h})\end{array}$ & $\begin{array}{c}\text { Reactor III } \\
(20 \mathrm{~h})\end{array}$ & $\begin{array}{l}\text { Time } \\
\text { (d) }\end{array}$ & $\begin{array}{c}\text { Reactor I } \\
(30 \mathrm{~h})\end{array}$ & $\begin{array}{c}\text { Reactor II } \\
(30 \mathrm{~h})\end{array}$ & $\begin{array}{c}\text { Reactor III } \\
(20 \mathrm{~h})\end{array}$ \\
\hline 0 & 73 & 83 & 38 & 0 & 106 & 94 & 38 \\
\hline 2 & 36 & 51 & 85 & 2 & 37 & 29 & 24 \\
\hline 4 & 46 & 52 & 14 & 4 & 47 & 16 & 28 \\
\hline$\overline{6}$ & 43 & 28 & 16 & 6 & 33 & 34 & 34 \\
\hline 8 & 16 & 4 & 14 & 8 & 22 & 11 & 19 \\
\hline 10 & 30 & 7 & 14 & 10 & 29 & 15 & 27 \\
\hline 13 & 41 & 11 & 17 & 13 & 33 & 25 & 33 \\
\hline 15 & 34 & 11 & 13 & 15 & 34 & 35 & 20 \\
\hline 17 & 29 & 12 & 22 & 17 & 48 & 40 & 33 \\
\hline 20 & 38 & 17 & 20 & 20 & 31 & 42 & 36 \\
\hline $\begin{array}{c}\text { average } \\
\text { last } 3 \text { values }\end{array}$ & 34 & 13 & 18 & $\begin{array}{c}\text { average } \\
\text { last } 3 \text { values }\end{array}$ & 38 & 39 & 30 \\
\hline
\end{tabular}


Table B.25 Emuent and First Port pH Values. Set 2

\begin{tabular}{|c|c|c|c|c|c|c|c|}
\hline \multicolumn{4}{|c|}{ 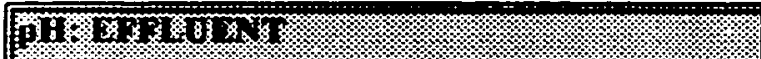 } & \multicolumn{4}{|c|}{ 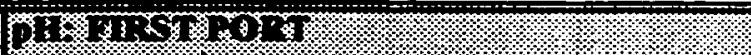 } \\
\hline $\begin{array}{l}\text { Time } \\
\text { (d) }\end{array}$ & $\begin{array}{c}\text { Reactor I } \\
(30 \mathrm{~h})\end{array}$ & $\begin{array}{c}\text { Reactor II } \\
(30 \mathrm{~h})\end{array}$ & $\begin{array}{l}\text { Reactor III } \\
(20 \mathrm{~h})\end{array}$ & $\begin{array}{l}\text { Time } \\
\text { (d) }\end{array}$ & $\begin{array}{c}\text { Reactor I } \\
(30 \mathrm{~h})\end{array}$ & $\begin{array}{c}\text { Reactor II } \\
(30 \mathrm{~h})\end{array}$ & $\begin{array}{c}\text { Reactor III } \\
(20 \mathrm{~h})\end{array}$ \\
\hline 0 & 5.6 & 4.9 & 5.9 & 0 & 5.4 & 4.6 & 5.0 \\
\hline 2 & 6.3 & 6.7 & 6.9 & 2 & 6.2 & 6.6 & 6.8 \\
\hline+ & 6.2 & 6.6 & 6.8 & 4 & 5.8 & 6.4 & 6.4 \\
\hline 6 & 5.9 & 6.5 & 6.7 & 6 & 5.7 & 6.3 & 6.3 \\
\hline 8 & 5.9 & 6.5 & 6.2 & 8 & 5.7 & 6.4 & 6.1 \\
\hline 10 & 6.1 & 6.7 & 6.6 & 10 & 6.0 & 6.5 & 6.5 \\
\hline 13 & 6.2 & 6.7 & 6.7 & 13 & 6.0 & 6.6 & 6.6 \\
\hline 15 & 6.3 & 6.8 & 6.6 & 15 & 6.1 & 6.6 & 6.6 \\
\hline 17 & 6.2 & 6.9 & 6.6 & 17 & 6.1 & 6.4 & 6.5 \\
\hline 20 & 6.3 & 6.7 & 6.7 & 20 & 6.2 & 6.6 & 6.5 \\
\hline $\begin{array}{c}\text { atverage } \\
\text { last } 3 \text { values }\end{array}$ & 6.3 & 6.8 & 6.6 & $\begin{array}{c}\text { average } \\
\text { last } 3 \text { values }\end{array}$ & 6.1 & 6.5 & 6.5 \\
\hline
\end{tabular}


Table B.26 Emuent ORP Values. Set 2

\begin{tabular}{|c|c|c|c|c|c|c|}
\hline \multicolumn{4}{|c|}{ 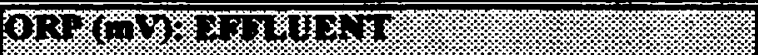 } & \multicolumn{3}{|c|}{ 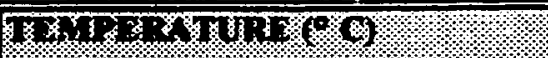 } \\
\hline $\begin{array}{l}\text { Time } \\
\text { (d) }\end{array}$ & $\begin{array}{c}\text { Reactor I } \\
(30 \mathrm{~h})\end{array}$ & $\begin{array}{l}\text { Reactor II } \\
(30 \mathrm{~h})\end{array}$ & $\begin{array}{c}\text { Reactor III } \\
(20 \mathrm{~h})\end{array}$ & $\begin{array}{c}\text { Reactor I } \\
(30 \mathrm{~h})\end{array}$ & $\begin{array}{c}\text { Reactor II } \\
(30 \mathrm{~h})\end{array}$ & $\begin{array}{c}\text { Reactor III } \\
(20 \mathrm{~h})\end{array}$ \\
\hline 0 & -332 & -371 & \begin{tabular}{|l|}
-378 \\
\end{tabular} & 19 & 19 & 19 \\
\hline 2 & -305 & -363 & -369 & 21 & 21 & $2 \mathrm{I}$ \\
\hline 4 & -327 & -386 & -374 & 21 & 21 & 21 \\
\hline 6 & -322 & -381 & -363 & 19 & 19 & 19 \\
\hline 8 & -316 & -378 & -352 & 20 & 20 & 20 \\
\hline 10 & -328 & -381 & -363 & 19 & 19 & 19 \\
\hline 13 & -338 & -386 & -368 & 18 & 18 & 18 \\
\hline 15 & -341 & -387 & -369 & 18 & 18 & 18 \\
\hline 17 & -343 & -388 & -372 & 22 & 22 & 22 \\
\hline 20 & -354 & -391 & -377 & 19 & 19 & 18 \\
\hline $\begin{array}{c}\text { average } \\
\text { last } 3 \text { values }\end{array}$ & -346 & -388 & -373 & 20 & 20 & 19 \\
\hline
\end{tabular}

Table B.27 First Port ORP Values. Set 2

\begin{tabular}{|c|c|c|c|c|c|c|}
\hline \multicolumn{4}{|c|}{ BRP (IVVY FIRST POHY } & \multicolumn{3}{|c|}{ 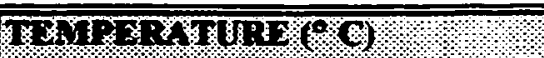 } \\
\hline $\begin{array}{c}\text { Time } \\
\text { (d) }\end{array}$ & $\begin{array}{c}\text { Reactor I } \\
(30 \mathrm{~h})\end{array}$ & $\begin{array}{c}\text { Reactor II } \\
(30 \mathrm{~h})\end{array}$ & $\begin{array}{c}\text { Reactor III } \\
(20 \mathrm{~h})\end{array}$ & $\begin{array}{c}\text { Reactor I } \\
(30 \mathrm{~h})\end{array}$ & $\begin{array}{c}\text { Reactor II } \\
(30 \mathrm{~h})\end{array}$ & $\begin{array}{c}\text { Reactor III } \\
(20 \mathrm{~h})\end{array}$ \\
\hline 0 & -327 & -371 & -376 & 19 & 19 & 19 \\
\hline 2 & -306 & -360 & -367 & 20 & 20 & 20 \\
\hline 4 & -326 & -370 & -386 & 22 & 22 & 21 \\
\hline 6 & -328 & -371 & -332 & 19 & 19 & 19 \\
\hline 8 & -329 & -374 & -341 & 20 & 20 & 20 \\
\hline 10 & -331 & -374 & -343 & 19 & 19 & 19 \\
\hline 13 & $-3+1$ & -380 & -345 & 19 & 19 & 19 \\
\hline 15 & -337 & -377 & -329 & 19 & 19 & 19 \\
\hline 17 & -350 & -381 & -353 & 21 & 21 & 21 \\
\hline 20 & -355 & -383 & -351 & 18 & 19 & 18 \\
\hline $\begin{array}{c}\text { average } \\
\text { last } 3 \text { values }\end{array}$ & -347 & -380 & -345 & 20 & 19 & 19 \\
\hline
\end{tabular}


Table B.28 Analyses along Reactors' Height

During Steady State. Set 2

\begin{tabular}{|c|c|c|c|}
\hline \multicolumn{4}{|c|}{$1110,1,3,1)$} \\
\hline $\begin{array}{c}\text { Sampling } \\
\text { Port }\end{array}$ & $\begin{array}{c}\text { Reactor I } \\
(30 \mathrm{~h})\end{array}$ & $\begin{array}{c}\text { Reactor II } \\
(30 \mathrm{~h})\end{array}$ & $\begin{array}{c}\text { Reactor III } \\
(20 \mathrm{~h})\end{array}$ \\
\hline effiuent & 222 & 185 & 177 \\
\hline 3rd port & 198 & 197 & 168 \\
\hline 2nd port & 183 & 183 & 149 \\
\hline Ist port & 197 & 187 & 141 \\
\hline \multicolumn{4}{|c|}{$14-1,1,1,1 \%$} \\
\hline \begin{tabular}{|c} 
Sampling \\
Porn
\end{tabular} & $\begin{array}{c}\text { Reactor I } \\
(30 \mathrm{~h})\end{array}$ & $\begin{array}{c}\text { Reactor II } \\
(30 \mathrm{~h})\end{array}$ & $\begin{array}{c}\text { Reactor III } \\
(20 \mathrm{~h})\end{array}$ \\
\hline effluent & 38 & 17 & 21 \\
\hline 3rd port & 40 & 23 & $\overline{22}$ \\
\hline 2nd port & 36 & 20 & 33 \\
\hline Ist port & 31 & 22 & 36 \\
\hline \multicolumn{4}{|l|}{13} \\
\hline \begin{tabular}{|c|} 
Sampling \\
Por
\end{tabular} & $\begin{array}{c}\text { Reactor I } \\
(30 \mathrm{~h})\end{array}$ & $\begin{array}{c}\text { Reactor II } \\
(30 \mathrm{~h})\end{array}$ & $\begin{array}{c}\text { Reactor III } \\
(20 \mathrm{~h}) \\
\end{array}$ \\
\hline effluent & 6.3 & 6.7 & 6.7 \\
\hline 3rd port & 6.3 & 6.8 & 6.6 \\
\hline 2nd port & 6.3 & 6.7 & 6.7 \\
\hline 1st port & 6.2 & 6.6 & 6.5 \\
\hline \multicolumn{4}{|c|}{ MIS $14 \%$} \\
\hline \begin{tabular}{|c|}
$\begin{array}{c}\text { Sampling } \\
\text { Port }\end{array}$ \\
\end{tabular} & $\begin{array}{c}\text { Reactor I } \\
(30 \mathrm{~h})\end{array}$ & $\begin{array}{c}\text { Reactor II } \\
(30 \mathrm{~h})\end{array}$ & $\begin{array}{c}\text { Reactor III } \\
(20 \mathrm{~h})\end{array}$ \\
\hline \multirow[t]{2}{*}{ effluent } & -354 & -391 & -377 \\
\hline & 19 & 19 & 18 \\
\hline \multirow[t]{2}{*}{ 3rd port } & -349 & -385 & -366 \\
\hline & 19 & 20 & 20 \\
\hline \multirow[t]{2}{*}{ 2nd port } & -353 & -383 & -361 \\
\hline & 20 & 20 & 19 \\
\hline \multirow[t]{2}{*}{ 1stpon } & -355 & -383 & -351 \\
\hline & 18 & 19 & 18 \\
\hline
\end{tabular}


Table B.29 Emuent and First Port Sulfide Concentrations. Set 3

\begin{tabular}{|c|c|c|c|c|c|c|c|}
\hline \multicolumn{4}{|c|}{ 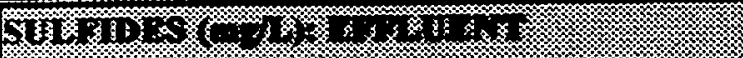 } & \multicolumn{4}{|c|}{ 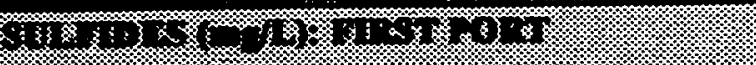 } \\
\hline $\begin{array}{c}\text { Time } \\
\text { (d) }\end{array}$ & $\begin{array}{c}\text { Reactor I } \\
(20 \mathrm{~h}) \\
\end{array}$ & $\begin{array}{c}\text { Reactor II } \\
(20 \mathrm{~h})\end{array}$ & $\begin{array}{c}\text { Reactor III } \\
(10 \mathrm{~h})\end{array}$ & $\begin{array}{l}\text { Time } \\
\text { (d) }\end{array}$ & $\begin{array}{c}\text { Reactor I } \\
(20 \mathrm{~h}) \\
\end{array}$ & $\begin{array}{c}\text { Reactor II } \\
(20 \mathrm{~h})\end{array}$ & $\begin{array}{c}\text { Reactor III } \\
(10 \mathrm{~h})\end{array}$ \\
\hline 0 & 196 & 187 & 116 & $\mathbf{0}$ & 181 & 180 & 125 \\
\hline 2 & 183 & 183 & 108 & 2 & 181 & 149 & 53 \\
\hline 4 & 193 & 172 & 82 & 4 & 177 & 160 & 73 \\
\hline 6 & 192 & 175 & 82 & 6 & 187 & 141 & 66 \\
\hline 9 & 191 & 182 & 75 & 9 & 161 & 150 & 47 \\
\hline 11 & 197 & 185 & 75 & 11 & 181 & 160 & 67 \\
\hline 13 & 197 & 177 & 73 & 13 & 190 & 171 & 79 \\
\hline \begin{tabular}{|c|} 
average \\
last 3 values
\end{tabular} & 195 & 182 & 74 & $\begin{array}{c}\text { average } \\
\text { last } 3 \text { values }\end{array}$ & 177 & 160 & 64 \\
\hline
\end{tabular}

Table B.30 Emuent and First Port VSS Concentrations. Set 3

\begin{tabular}{|c|c|c|c|c|c|c|c|}
\hline $\begin{array}{c}\text { US } \\
\text { Time } \\
(\mathrm{d})\end{array}$ & $\begin{array}{c}\text { Reactor I } \\
(20 \mathrm{~h})\end{array}$ & $\begin{array}{c}\text { Reactor II } \\
(20 \mathrm{~h})\end{array}$ & $\begin{array}{c}\text { Reactor III } \\
(10 \mathrm{~h})\end{array}$ & $\begin{array}{c}\text { Time } \\
(\mathrm{d})\end{array}$ & $\begin{array}{c}\text { Reactor I } \\
(20 \mathrm{~h})\end{array}$ & $\begin{array}{c}\text { Reactor II } \\
(20 \mathrm{~h})\end{array}$ & $\begin{array}{c}\text { Reactor III } \\
(10 \mathrm{~h})\end{array}$ \\
\hline 0 & 43 & 46 & 38 & 0 & 154 & 26 & 41 \\
\hline 2 & 38 & 20 & 20 & 2 & 38 & 34 & 10 \\
\hline 4 & 24 & 13 & 23 & 4 & 21 & 16 & 41 \\
\hline 6 & 23 & 16 & 18 & 6 & 15 & 30 & 24 \\
\hline 9 & 16 & 10 & 16 & 9 & 26 & 18 & 11 \\
\hline 11 & 16 & 10 & 19 & 11 & 24 & 36 & 21 \\
\hline 13 & 17 & 12 & 20 & 13 & 25 & 35 & 20 \\
\hline average & 16 & 11 & 18 & $\begin{array}{c}\text { average } \\
\text { last 3 values }\end{array}$ & 25 & 30 & 17 \\
\hline last 3 values & 16 & & & & & \\
\hline
\end{tabular}

Table B.31 Emuent and First Port pH Values. Set 3

\begin{tabular}{|c|c|c|c|c|c|c|c|}
\hline \begin{tabular}{c} 
TII If \\
\hline $\begin{array}{c}\text { Time } \\
(\mathrm{d})\end{array}$
\end{tabular} & $\begin{array}{c}\text { Reactor I } \\
(20 \mathrm{~h})\end{array}$ & $\begin{array}{c}\text { Reactor II } \\
(20 \mathrm{~h})\end{array}$ & $\begin{array}{c}\text { Reactor III } \\
(10 \mathrm{~h})\end{array}$ & $\begin{array}{c}\text { Time } \\
(\mathrm{d})\end{array}$ & $\begin{array}{c}\text { Reactor I } \\
(20 \mathrm{~h})\end{array}$ & $\begin{array}{c}\text { Reactor II } \\
(20 \mathrm{~h})\end{array}$ & $\begin{array}{c}\text { Reactor III } \\
(10 \mathrm{~h})\end{array}$ \\
\hline 0 & 6.4 & 6.7 & 6.7 & 0 & 6.2 & 6.6 & 6.5 \\
\hline 2 & 6.3 & 6.8 & 6.9 & 2 & 6.3 & 6.7 & 6.8 \\
\hline 4 & 6.7 & 6.9 & 6.9 & 4 & 6.7 & 6.9 & 6.7 \\
\hline 6 & 6.7 & 6.8 & 6.8 & 6 & 6.7 & 6.8 & 6.7 \\
\hline 9 & 6.8 & 6.9 & 6.9 & 9 & 6.7 & 6.8 & 6.8 \\
\hline 11 & 6.8 & 6.7 & 6.8 & 11 & 6.7 & 6.7 & 6.9 \\
\hline 13 & 6.8 & 6.7 & 6.8 & 13 & 6.7 & 6.8 & 6.9 \\
\hline $\begin{array}{c}\text { average } \\
\text { last 3 values }\end{array}$ & 6.8 & 6.8 & 6.8 & $\begin{array}{c}\text { average } \\
\text { last 3 values }\end{array}$ & 6.7 & 6.8 & 6.9 \\
\hline
\end{tabular}


Table B.32 Emuent ORP Values. Set 3

\begin{tabular}{|c|c|c|c|c|c|c|}
\hline \hline Reactor I & $\begin{array}{c}\text { Reactor II } \\
(20 \mathrm{~h})\end{array}$ & $\begin{array}{c}\text { Reactor III } \\
(10 \mathrm{~h})\end{array}$ & $\begin{array}{c}\text { Reactor I } \\
(20 \mathrm{~h})\end{array}$ & $\begin{array}{c}\text { Reactor II } \\
(20 \mathrm{~h})\end{array}$ & $\begin{array}{c}\text { Reactor III } \\
(10 \mathrm{~h})\end{array}$ \\
\hline $\begin{array}{c}\text { Time } \\
(20 \mathrm{~h})\end{array}$ & -355 & -393 & -377 & 20 & 20 & 20 \\
\hline 0 & -343 & -381 & -360 & 22 & 20 & 20 \\
\hline 2 & -359 & -381 & -350 & 19 & 19 & 19 \\
\hline 4 & -379 & -383 & -364 & 20 & 20 & 20 \\
\hline 6 & -378 & -382 & -360 & 20 & 20 & 20 \\
\hline 9 & -376 & -381 & -353 & 19 & 19 & 19 \\
\hline 11 & -378 & -382 & -354 & 20 & 19 & 18 \\
\hline 13 & -377 & -382 & -356 & 20 & 19 & 19 \\
\hline $\begin{array}{c}\text { average } \\
\text { last 3 values }\end{array}$ & -377 & & & & \\
\hline
\end{tabular}

Table B.33 First Port ORP Values. Set 3

\begin{tabular}{|c|c|c|c|c|c|c|}
\hline \multicolumn{4}{|c|}{ 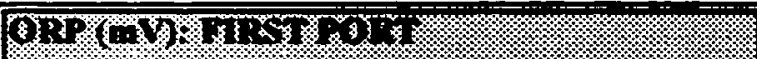 } & \multicolumn{3}{|c|}{ 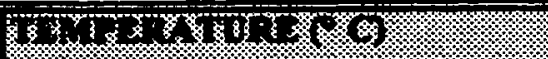 } \\
\hline $\begin{array}{l}\text { Time } \\
\text { (d) }\end{array}$ & $\begin{array}{c}\text { Reactor I } \\
(20 \mathrm{~h})\end{array}$ & $\begin{array}{c}\text { Reactor II } \\
(20 \mathrm{~h})\end{array}$ & $\begin{array}{c}\text { Reactor III } \\
(10 \mathrm{~h})\end{array}$ & $\begin{array}{c}\text { Reactor I } \\
(20 \mathrm{~h})\end{array}$ & $\begin{array}{c}\text { Reactor II } \\
(20 \mathrm{~h})\end{array}$ & $\begin{array}{c}\text { Reactor III } \\
(10 \mathrm{~h})\end{array}$ \\
\hline 0 & -355 & -389 & -374 & 20 & 20 & 20 \\
\hline 2 & -353 & -371 & -339 & 20 & 20 & 20 \\
\hline 4 & -357 & -365 & -347 & 19 & 19 & 19 \\
\hline 6 & -369 & -368 & -331 & 20 & 20 & 20 \\
\hline 9 & -378 & -356 & -332 & 20 & 20 & 20 \\
\hline 11 & -375 & -370 & -332 & 19 & 19 & 20 \\
\hline 13 & -376 & -359 & -330 & 20 & 19 & 20 \\
\hline $\begin{array}{c}\text { average } \\
\text { last } 3 \text { values }\end{array}$ & -376 & -362 & -331 & 20 & 19 & 20 \\
\hline
\end{tabular}


Table B.34 Analyses along Reactors' Height During Steady State. Set 3

\begin{tabular}{|c|c|c|c|}
\hline \multicolumn{4}{|c|}{ Wn: $1: 1,1)$} \\
\hline $\begin{array}{c}\text { Sampling } \\
\text { Port }\end{array}$ & $\begin{array}{c}\text { Reactor I } \\
(20 \mathrm{~h})\end{array}$ & $\begin{array}{c}\text { Reactor II } \\
(20 \mathrm{~h})\end{array}$ & $\begin{array}{c}\text { Reactor III } \\
(10 \mathrm{~h})\end{array}$ \\
\hline effluent & 197 & 177 & 73 \\
\hline 3rd port & 197 & 171 & 74 \\
\hline 2nd pont & 181 & 166 & 71 \\
\hline Ist port & 190 & 171 & 79 \\
\hline \multicolumn{4}{|c|}{ WSO $1 \% 1 \%$} \\
\hline \begin{tabular}{|c|} 
Sampling \\
Port
\end{tabular} & $\begin{array}{c}\text { Reactor I } \\
(20 \mathrm{~h})\end{array}$ & $\begin{array}{c}\text { Reactor II } \\
(20 \mathrm{~h})\end{array}$ & $\begin{array}{c}\text { Reactor III } \\
(10 \mathrm{~h})\end{array}$ \\
\hline effluent & 16 & 10 & 19 \\
\hline 3rd port & 15 & 12 & 15 \\
\hline 2nd port & 17 & 12 & 18 \\
\hline IsI pon & 24 & 36 & 21 \\
\hline \multicolumn{4}{|l|}{ pH } \\
\hline $\begin{array}{c}\text { Sampling } \\
\text { Port }\end{array}$ & $\begin{array}{c}\text { Reactor I } \\
(20 \mathrm{~h})\end{array}$ & $\begin{array}{c}\text { Reactor II } \\
(20 \mathrm{~h})\end{array}$ & $\begin{array}{c}\text { Reactor III } \\
(10 \mathrm{~h})\end{array}$ \\
\hline efluent & 6.7 & 6.7 & 6.8 \\
\hline ird pon & 6.8 & 6.6 & 6.8 \\
\hline 2nd port & 6.7 & 6.7 & 6.7 \\
\hline Ist port & 6.7 & 6.7 & 6.8 \\
\hline \multicolumn{4}{|c|}{$\begin{array}{l}\text { GRP }(m) \\
(\%)\end{array}$} \\
\hline $\begin{array}{c}\text { Sampling } \\
\text { Por }\end{array}$ & $\begin{array}{c}\text { Reacior I } \\
(20 \mathrm{~h})\end{array}$ & $\begin{array}{l}\text { Reactor II } \\
(20 \mathrm{~h})\end{array}$ & $\begin{array}{l}\text { Reactor III } \\
(10 \mathrm{~h})\end{array}$ \\
\hline \multirow[t]{2}{*}{ effluent } & -.367 & -375 & -360 \\
\hline & 20 & 20 & 19 \\
\hline \multirow[t]{2}{*}{ 3rd port } & -369 & -377 & -335 \\
\hline & 20 & 20 & 19 \\
\hline \multirow[t]{2}{*}{ 2nd por } & -370 & -360 & -332 \\
\hline & 20 & 20 & 20 \\
\hline \multirow[t]{2}{*}{ 1st port } & -372 & -367 & -337 \\
\hline & 20 & 20 & 20 \\
\hline
\end{tabular}


Table B.35 Emuent and First Port Sulfide Concentrations. Set 4

\begin{tabular}{|c|c|c|c|c|c|}
\hline \multicolumn{3}{|c|}{ 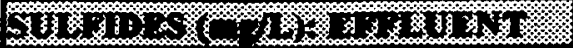 } & \multicolumn{3}{|c|}{ 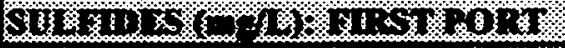 } \\
\hline $\begin{array}{l}\text { Time } \\
\text { (d) }\end{array}$ & $\begin{array}{c}\text { Reactor II } \\
(10 \mathrm{~h})\end{array}$ & $\begin{array}{c}\text { Reactor III } \\
(5 \mathrm{~h})\end{array}$ & $\begin{array}{l}\text { Time } \\
\text { (d) }\end{array}$ & $\begin{array}{c}\text { Reactor II } \\
(10 \mathrm{~h})\end{array}$ & $\begin{array}{c}\text { Reactor III } \\
(5 \mathrm{~h})\end{array}$ \\
\hline & $12 \mathrm{~kg} / \mathrm{d} / \mathrm{m}^{3}$ & $6 \mathrm{~kg} / \mathrm{d} / \mathrm{m}^{3}$ & & $12 \mathrm{~kg} / \mathrm{d} / \mathrm{m}^{3}$ & $6 \mathrm{~kg} / \mathrm{d} / \mathrm{m}^{3}$ \\
\hline 0 & 159 & 58 & 0 & 82 & 52 \\
\hline 2 & 53 & 26 & 2 & 12 & 4 \\
\hline 4 & 160 & & 4 & 64 & \\
\hline 6 & 170 & & 6 & 58 & \\
\hline 8 & 165 & & 8 & 56 & \\
\hline 10 & 162 & & 10 & 47 & \\
\hline $\begin{array}{c}\text { average } \\
\text { last } 3 \text { values }\end{array}$ & 165 & & $\begin{array}{c}\text { average } \\
\text { last } 3 \text { values }\end{array}$ & 53 & \\
\hline
\end{tabular}

Table B.36 Emuent and First Port VSS Concentrations. Set 4

\begin{tabular}{|c|c|c|c|c|c|}
\hline \multicolumn{3}{|c|}{ 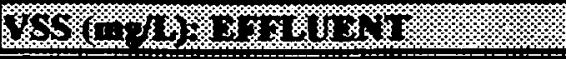 } & \multicolumn{3}{|c|}{ 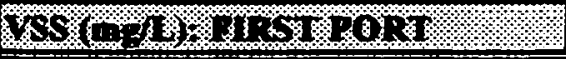 } \\
\hline $\begin{array}{l}\text { Time } \\
\text { (d) }\end{array}$ & $\begin{array}{c}\text { Reactor II } \\
(10 \mathrm{~h})\end{array}$ & $\begin{array}{c}\text { Reactor III } \\
(5 \mathrm{~h})\end{array}$ & $\begin{array}{l}\text { Time } \\
\text { (d) }\end{array}$ & $\begin{array}{c}\text { Reactor II } \\
(10 \mathrm{~h})\end{array}$ & $\begin{array}{c}\text { Reactor III } \\
(5 \mathrm{~h})\end{array}$ \\
\hline & $12 \mathrm{~kg} / \mathrm{d} / \mathrm{m}^{3}$ & $6 \mathrm{~kg} / \mathrm{d} / \mathrm{m}^{3}$ & & $12 \mathrm{~kg} / \mathrm{d} / \mathrm{m}^{3}$ & $6 \mathrm{~kg} / \mathrm{d} / \mathrm{m}^{3}$ \\
\hline 0 & 22 & 21 & 0 & 34 & 20 \\
\hline 2 & 19 & 3 & 2 & 24 & 6 \\
\hline 4 & 30 & & 4 & 30 & \\
\hline 6 & 29 & & 6 & 45 & \\
\hline 8 & 30 & & 8 & 65 & \\
\hline 10 & 29 & & 10 & 51 & \\
\hline $\begin{array}{c}\text { average } \\
\text { last } 3 \text { values }\end{array}$ & 29 & & $\begin{array}{c}\text { average } \\
\text { last } 3 \text { values }\end{array}$ & 54 & \\
\hline
\end{tabular}

Table B.37 Emuent and First Port pH Values. Set 4

\begin{tabular}{|c|c|c|c|c|c|}
\hline \multicolumn{3}{|c|}{ 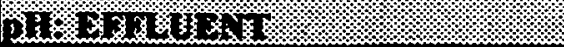 } & \multicolumn{3}{|c|}{ 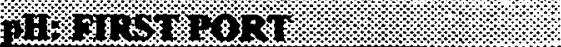 } \\
\hline $\begin{array}{l}\text { Time } \\
\text { (d) }\end{array}$ & $\begin{array}{c}\text { Reactor II } \\
(10 \mathrm{~h})\end{array}$ & $\begin{array}{c}\text { Reactor III } \\
(5 \mathrm{~h})\end{array}$ & $\begin{array}{l}\text { Time } \\
\text { (d) }\end{array}$ & $\begin{array}{c}\text { Reactor II } \\
(10 \mathrm{~h})\end{array}$ & $\begin{array}{l}\text { Reactor III } \\
(5 \mathrm{~h})\end{array}$ \\
\hline & $12 \mathrm{~kg} / \mathrm{d} / \mathrm{m}^{3}$ & $6 \mathrm{~kg} / \mathrm{d}^{3} \mathrm{~m}^{3}$ & & $12 \mathrm{~kg} / \mathrm{d} / \mathrm{m}^{3}$ & $6 \mathrm{~kg} / \mathrm{d} / \mathrm{m}^{3}$ \\
\hline 0 & 6.5 & 6.5 & 0 & 6.3 & 6.2 \\
\hline 2 & 7.1 & 7.2 & 2 & 7.0 & 7.4 \\
\hline 4 & 7.0 & & 4 & 6.9 & \\
\hline$\overline{6}$ & 7.1 & & 6 & 7.1 & \\
\hline 8 & 7.0 & & 8 & 6.9 & \\
\hline 10 & 6.9 & & 10 & 6.8 & \\
\hline $\begin{array}{c}\text { average } \\
\text { last } 3 \text { values }\end{array}$ & 7.0 & & $\begin{array}{c}\text { average } \\
\text { last } 3 \text { values }\end{array}$ & 6.9 & \\
\hline
\end{tabular}


Table B.38 Emuent ORP Values. Set 4

\begin{tabular}{|c|c|c|c|c|}
\hline $\begin{array}{c}\text { Time } \\
\text { (d) }\end{array}$ & $\begin{array}{c}\text { Reactor II } \\
(10 \mathrm{~h})\end{array}$ & $\begin{array}{c}\text { Reactor III } \\
(5 \mathrm{~h})\end{array}$ & $\begin{array}{c}\text { Reactor II } \\
(10 \mathrm{~h})\end{array}$ & $\begin{array}{c}\text { Reactor III } \\
(5 \mathrm{~h})\end{array}$ \\
\hline 0 & $12 \mathrm{~kg} / \mathrm{d}^{3}$ & $6 \mathrm{~kg} / \mathrm{d}^{3}$ & $12 \mathrm{~kg} / \mathrm{d}^{3}$ & $6 \mathrm{~kg} / \mathrm{d}^{3}$ \\
\hline & -382 & -342 & 19 & 20 \\
\hline 2 & -341 & -348 & 20 & 20 \\
\hline 4 & -367 & & 20 & \\
\hline 6 & -362 & & 19 & \\
\hline 8 & -367 & & 20 & \\
\hline I0 & -363 & & 20 & \\
\hline average & & & & \\
\hline last 3 values & -364 & & & \\
\hline
\end{tabular}

Table B.39 First Port ORP Values. Set 4

\begin{tabular}{|c|c|c|c|c|}
\hline \multicolumn{3}{|c|}{ 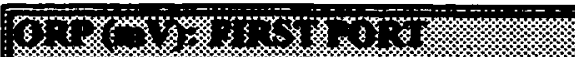 } & \multicolumn{2}{|c|}{ 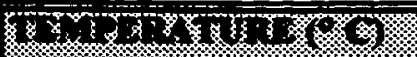 } \\
\hline $\begin{array}{l}\text { Time } \\
\text { (d) }\end{array}$ & $\begin{array}{c}\text { Reactor II } \\
(10 \mathrm{~h})\end{array}$ & $\begin{array}{c}\text { Reactor III } \\
\text { (5 h) }\end{array}$ & $\begin{array}{c}\text { Reactor II } \\
(10 \mathrm{~h})\end{array}$ & $\begin{array}{c}\text { Reactor III } \\
\text { (5 h) }\end{array}$ \\
\hline & $12 \mathrm{~kg} / \mathrm{d} / \mathrm{m}^{3}$ & $6 \mathrm{~kg} / \mathrm{d} / \mathrm{m}^{3}$ & $12 \mathrm{~kg} / \mathrm{d} / \mathrm{m}^{3}$ & $6 \mathrm{~kg} / \mathrm{d} / \mathrm{m}^{3}$ \\
\hline 0 & -381 & -349 & 20 & 19 \\
\hline 2 & -290 & 83 & 20 & 19 \\
\hline 4 & -341 & & 21 & \\
\hline 6 & -326 & & 20 & \\
\hline 8 & -341 & & 21 & \\
\hline 10 & -303 & & 20 & \\
\hline $\begin{array}{c}\text { average } \\
\text { last } 3 \text { values }\end{array}$ & -323 & & 20 & \\
\hline
\end{tabular}


Table B.40 Analyses along Reactors' Height

During Steady State. Set 4

\begin{tabular}{|c|c|c|c|}
\hline \multicolumn{4}{|c|}{$1: 1,1=$} \\
\hline $\begin{array}{l}\text { Sampling } \\
\text { Port }\end{array}$ & Reactor I & $\begin{array}{l}\text { Reactor II } \\
(10 \mathrm{~h})\end{array}$ & Reactor III \\
\hline effluent & NR & 162 & NR \\
\hline 3rd port & NR & 146 & NR \\
\hline 2nd port & NR & 127 & NR \\
\hline Ist port & NR & 47 & NR \\
\hline \multicolumn{4}{|c|}{ 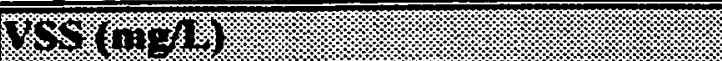 } \\
\hline $\begin{array}{l}\text { Sampling } \\
\text { Port }\end{array}$ & Reactor I & $\begin{array}{c}\text { Reactor II } \\
(10 \mathrm{~h})\end{array}$ & Reactor III \\
\hline effluent & NR & 29 & NR \\
\hline 3rd port & NR & 35 & NR \\
\hline 2nd port & NR & 41 & NR \\
\hline Ist port & NR & 51 & NR \\
\hline \multicolumn{4}{|l|}{113} \\
\hline $\begin{array}{l}\text { Sampling } \\
\text { Port }\end{array}$ & Reactor I & $\begin{array}{l}\text { Reactor II } \\
(10 \mathrm{~h})\end{array}$ & Reactor III \\
\hline effluent & NR & 6.9 & NR \\
\hline 3 rd port & NR & 6.8 & NR \\
\hline 2nd port & NR & 6.8 & NR \\
\hline 1st port & NR & 6.8 & NR \\
\hline \multicolumn{4}{|c|}{ 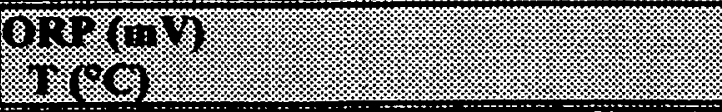 } \\
\hline $\begin{array}{c}\text { Sampling } \\
\text { Port }\end{array}$ & Reactor I & $\begin{array}{c}\text { Reactor II } \\
(\mathrm{I} 0 \mathrm{~h})\end{array}$ & Reactor III \\
\hline \multirow[t]{2}{*}{ effluent } & NR & -363 & NR \\
\hline & & 20 & \\
\hline \multirow[t]{2}{*}{3 rd port } & NR & -356 & NR \\
\hline & & 21 & \\
\hline \multirow[t]{2}{*}{ 2nd port } & NR & -345 & NR \\
\hline & & 21 & \\
\hline 1st port & NR & -303 & NR \\
\hline & & 20 & \\
\hline
\end{tabular}

*NR= Not Recorded 
Table B.41 Emuent and First Port Sulfide Concentrations.

Set 5

\begin{tabular}{|c|c|c|c|c|c|}
\hline \multicolumn{3}{|c|}{ 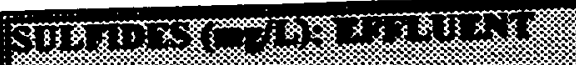 } & \multicolumn{3}{|c|}{ 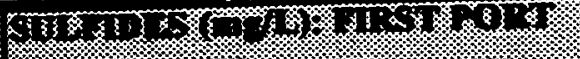 } \\
\hline $\begin{array}{c}\text { Time } \\
\text { (d) }\end{array}$ & $\begin{array}{c}\text { Reactor II } \\
(12 \mathrm{~h})\end{array}$ & $\begin{array}{c}\text { Reactor II } \\
(7.5 \mathrm{~h})\end{array}$ & $\begin{array}{l}\text { Time } \\
\text { (d) }\end{array}$ & $\begin{array}{c}\text { Reactor II } \\
(12 \mathrm{~h})\end{array}$ & $\begin{array}{c}\text { Reactor II } \\
(7.5 \mathrm{~h}) \\
\end{array}$ \\
\hline & $12 \mathrm{~kg} / \mathrm{d} / \mathrm{m}^{3}$ & $12 \mathrm{~kg} / \mathrm{d} / \mathrm{m}^{3}$ & & $12 \mathrm{~kg} / \mathrm{d} / \mathrm{m}^{3}$ & $12 \mathrm{~kg} / \mathrm{d} / \mathrm{m}^{3}$ \\
\hline 0 & 163 & 187 & 0 & 87 & 140 \\
\hline 2 & 197 & 125 & 2 & 131 & 42 \\
\hline 4 & 189 & 138 & 4 & 104 & 50 \\
\hline 7 & 194 & 152 & 7 & 127 & 76 \\
\hline $\begin{array}{c}\text { average } \\
\text { last } 3 \text { values }\end{array}$ & 193 & 138 & $\begin{array}{c}\text { average } \\
\text { last } 3 \text { values }\end{array}$ & 121 & 56 \\
\hline
\end{tabular}

\section{Table B.42 Emuent and First Port VSS Concentrations. \\ Set 5}

\begin{tabular}{|c|c|c|c|c|c|}
\hline \multicolumn{3}{|c|}{ 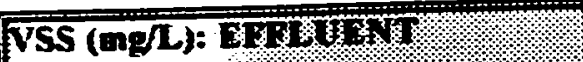 } & \multicolumn{3}{|c|}{ 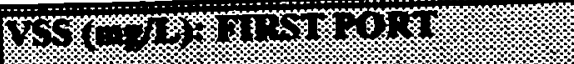 } \\
\hline $\begin{array}{l}\text { Time } \\
\text { (d) }\end{array}$ & $\begin{array}{c}\text { Reactor II } \\
(12 \mathrm{~h})\end{array}$ & $\begin{array}{c}\text { Reactor II } \\
(7.5 \mathrm{~h})\end{array}$ & $\begin{array}{l}\text { Time } \\
\text { (d) }\end{array}$ & $\begin{array}{c}\text { Reactor II } \\
(12 \mathrm{~h})\end{array}$ & $\begin{array}{c}\text { Reactor II } \\
(7.5 \mathrm{~h})\end{array}$ \\
\hline & $12 \mathrm{~kg} / \mathrm{d} / \mathrm{m}^{3}$ & $12 \mathrm{~kg} / \mathrm{d} / \mathrm{m}^{3}$ & & $12 \mathrm{~kg} / \mathrm{d} / \mathrm{m}^{3}$ & $12 \mathrm{~kg} / \mathrm{d} / \mathrm{m}^{3}$ \\
\hline 11 & 28 & 20 & 0 & 50 & 33 \\
\hline$:$ & 19 & 26 & 2 & 37 & 20 \\
\hline 1 & 30 & 18 & 4 & 47 & 16 \\
\hline$=$ & 29 & 14 & 7 & 52 & 14 \\
\hline 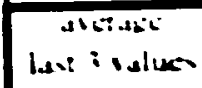 & 26 & 19 & $\begin{array}{c}\text { average } \\
\text { last } 3 \text { values }\end{array}$ & 45 & 17 \\
\hline
\end{tabular}

Table B.43 Emuent and First Port pH Values.

Set 5

\begin{tabular}{|c|c|c|c|c|c|}
\hline \multicolumn{3}{|c|}{ Pi: ERLUENT } & \multicolumn{3}{|c|}{ 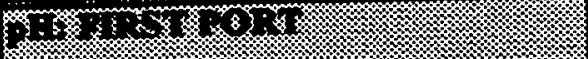 } \\
\hline $\begin{array}{l}\text { Tink } \\
\text { Idi }\end{array}$ & $\begin{array}{c}\text { Reactor II } \\
(12 \mathrm{~h})\end{array}$ & $\begin{array}{c}\text { Reactor II } \\
(7.5 \mathrm{~h}) \\
\end{array}$ & $\begin{array}{l}\text { Time } \\
\text { (d) }\end{array}$ & $\begin{array}{c}\text { Reactor II } \\
(12 \mathrm{~h})\end{array}$ & $\begin{array}{c}\text { Reactor II } \\
(7.5 \mathrm{~h}) \\
\end{array}$ \\
\hline & $12 \mathrm{kgd} \mathrm{d}^{3}$ & $12 \mathrm{~kg} d \mathrm{~m}^{3}$ & & $12 \mathrm{~kg} / \mathrm{d} / \mathrm{m}^{3}$ & $12 \mathrm{~kg} / \mathrm{d} / \mathrm{m}^{3}$ \\
\hline 11 & 6.9 & 7.0 & 0 & 6.8 & 6.9 \\
\hline$?$ & 6.7 & 7.0 & 2 & 6.9 & 7.0 \\
\hline 1 & 6.8 & 7.1 & 4 & 6.8 & 7.1 \\
\hline$=$ & 6.9 & 7.1 & 7 & 6.8 & 7.0 \\
\hline $\begin{array}{c}\text { Alctatot } \\
\text { last I values }\end{array}$ & 6.8 & 7.1 & $\begin{array}{c}\text { average } \\
\text { last } 3 \text { values }\end{array}$ & 6.8 & 7.0 \\
\hline
\end{tabular}


Table B.44 Emuent ORP Values. Set 5

\begin{tabular}{|c|c|c|c|c|}
\hline & (3) \\
\hline $\begin{array}{c}\text { Time } \\
\text { (d) }\end{array}$ & $\begin{array}{c}\text { Reactor II } \\
(12 \mathrm{~h})\end{array}$ & $\begin{array}{c}\text { Reactor II } \\
(7.5 \mathrm{~h})\end{array}$ & $\begin{array}{c}\text { Reactor II } \\
(12 \mathrm{~h})\end{array}$ & $\begin{array}{c}\text { Reactor II } \\
(7.5 \mathrm{~h})\end{array}$ \\
\hline 0 & $12 \mathrm{~kg} / \mathrm{dm}^{3}$ & $12 \mathrm{~kg} / \mathrm{d}^{3}$ & $12 \mathrm{~kg} / \mathrm{d}^{3}$ & $12 \mathrm{~kg} / \mathrm{d}^{3}$ \\
\hline 2 & -363 & -369 & 20 & 20 \\
\hline 4 & -373 & -361 & 20 & 20 \\
\hline 7 & -373 & -364 & 22 & 20 \\
\hline $\begin{array}{c}\text { average } \\
\text { last 3 values }\end{array}$ & -370 & -363 & 20 & 19 \\
\hline
\end{tabular}

Table B.45 First Port ORP Values. Set 5

\begin{tabular}{|c|c|c|c|c|}
\hline $\begin{array}{c}\text { Time } \\
\text { (d) }\end{array}$ & $\begin{array}{c}\text { Reactor II } \\
(12 \mathrm{~h})\end{array}$ & $\begin{array}{c}\text { Reactor II } \\
(7.5 \mathrm{~h})\end{array}$ & $\begin{array}{c}\text { Reactor II } \\
(12 \mathrm{~h})\end{array}$ & $\begin{array}{c}\text { Reactor II } \\
(7.5 \mathrm{~h})\end{array}$ \\
\hline & $12 \mathrm{~kg} / \mathrm{dm}^{3}$ & $12 \mathrm{~kg} / \mathrm{dm}^{3}$ & $12 \mathrm{~kg} / \mathrm{d} / \mathrm{m}^{3}$ & $12 \mathrm{~kg} / \mathrm{d}^{3}$ \\
\hline 0 & -303 & -356 & 20 & 20 \\
\hline 2 & -355 & -320 & 21 & 21 \\
\hline 4 & -345 & -326 & 22 & 21 \\
\hline 7 & -329 & -335 & 20 & 20 \\
\hline $\begin{array}{c}\text { average } \\
\text { last 3 values }\end{array}$ & -343 & -327 & 21 & 20 \\
\hline
\end{tabular}


Table B.46 Analyses along Reactors' Height During Steady State. Set 5

\begin{tabular}{|c|c|c|c|}
\hline \multicolumn{4}{|c|}{ 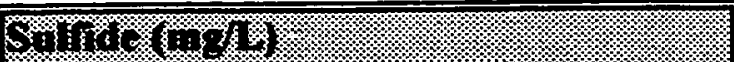 } \\
\hline $\begin{array}{c}\text { Sampling } \\
\text { Port }\end{array}$ & Reactor I & $\begin{array}{c}\text { Reactor II } \\
(12 \mathrm{~h})\end{array}$ & $\begin{array}{c}\text { Reactor II } \\
(7.5 \mathrm{~h})\end{array}$ \\
\hline effluent & $\overline{\mathrm{NR}}$ & 194 & 152 \\
\hline 3rd port & NR & 179 & 94 \\
\hline 2nd port & NR & 149 & 98 \\
\hline 1st port & NR & 69 & 76 \\
\hline \multicolumn{4}{|c|}{ Hor. } \\
\hline $\begin{array}{c}\text { Sampling } \\
\text { Port }\end{array}$ & Reactor I & $\begin{array}{l}\text { Reactor II } \\
(12 \mathrm{~h})\end{array}$ & $\begin{array}{c}\text { Reactor II } \\
(7.5 \mathrm{~h})\end{array}$ \\
\hline effluent & NR & 29 & 14 \\
\hline 3rd port & NR & 52 & 24 \\
\hline 2nd port & NR & 50 & 24 \\
\hline Ist port & NR & 52 & 14 \\
\hline \multicolumn{4}{|l|}{ 1915. } \\
\hline $\begin{array}{c}\text { Sampling } \\
\text { Port }\end{array}$ & Reactor I & $\begin{array}{c}\text { Reactor II } \\
(12 \mathrm{~h})\end{array}$ & $\begin{array}{c}\text { Reactor II } \\
(7.5 \mathrm{~h})\end{array}$ \\
\hline effluent & $\overline{N R}$ & 6.9 & 7.1 \\
\hline $3 \mathrm{rd}$ port & NR & 6.9 & 7.0 \\
\hline 2nd port & NR & 6.8 & 7.0 \\
\hline lst port & NR & 6.8 & 7.0 \\
\hline \multicolumn{4}{|c|}{ (6) II) } \\
\hline $\begin{array}{c}\text { Sampling } \\
\text { Port }\end{array}$ & Reactor I & $\begin{array}{l}\text { Reactor II } \\
(12 \mathrm{~h})\end{array}$ & $\begin{array}{c}\text { Reactor II } \\
(7.5 \mathrm{~h})\end{array}$ \\
\hline \multirow[t]{2}{*}{ effluent } & NR & -365 & -363 \\
\hline & & 20 & 19 \\
\hline \multirow[t]{2}{*}{$3 \mathrm{rd}$ port } & $\mathrm{NR}$ & -357 & -357 \\
\hline & & 21 & 20 \\
\hline \multirow[t]{2}{*}{ 2nd port } & $\overline{\mathrm{NR}}$ & -345 & -350 \\
\hline & & 20 & 20 \\
\hline \multirow[t]{2}{*}{ 1st port } & NR & -329 & -335 \\
\hline & & 20 & 20 \\
\hline
\end{tabular}

*NR= Not Recorded 
APPENDIX C

STATISTICS

The following statistical calculations were carried out during this study.

Under steady state conditions in the reactor, six different samples were withdrawn from the same port within a period of 15 minutes to determine the confidence in analyses.

\section{C.1 Sulfide Determination}

\begin{tabular}{|c|c|}
\hline Measurement & mg SH \\
\hline 1 & 215 \\
\hline 2 & 207 \\
\hline 3 & 196 \\
\hline 4 & 210 \\
\hline 5 & 200 \\
\hline 6 & 224 \\
\hline$n=6$ & $\bar{x}=209$ \\
\hline
\end{tabular}

$\bar{x}=\frac{\sum x}{n}$

$s=\left[\frac{\sum(x-x)^{2}}{(n-1)}\right.$

where, 
$s=$ standard deviation

$x=$ result of each measurement

$\mathrm{n}=$ number of measurements

$\overline{\mathrm{x}}=$ mean value

It is sufficiently accurate to state that $95 \%$ of the values are within $\pm \frac{t^{*} s}{\sqrt{n}}$ where $t=2.8$ for $n=6$. The use of $t$ compensates for the tendency of a small number of values to underestimate uncertainty (APHA, 1995).

It was determined that the standard deviation value was $\pm 9.98 \mathrm{mg} / \mathrm{L}$ and the $95 \%$ confidence interval was $\pm 11 \mathrm{mg} / \mathrm{L}$ of the mean value. Thus, if the difference in results falls within $\pm 5 \%$ of the mean value, the variation is considered to be statistical.

\section{C.2 VSS Determination}

\begin{tabular}{|c|c|}
\hline Mersurement & ing VSSA \\
\hline 1 & 48 \\
\hline 2 & 49 \\
\hline 3 & 53 \\
\hline 4 & 45 \\
\hline 5 & 50 \\
\hline 6 & 45 \\
\hline$n=6$ & $\bar{x}=48$ \\
\hline
\end{tabular}




$$
\begin{aligned}
& \bar{x}=\frac{\sum x}{n} \\
& s=\left[\frac{\sum(x-\bar{x})^{2}}{(n-1)}\right]^{1 / 2}
\end{aligned}
$$

where,

$\mathrm{s}=$ standard deviation

$\mathrm{x}=$ result of each measurement

$\mathrm{n}=$ number of measurements

$\overline{\mathrm{x}}=$ mean value

It is sufficiently accurate to state that $95 \%$ of the values are within $\pm \frac{t^{*} s}{\sqrt{n}}$ where $t=2.8$ for $n=6$. The use of $t$ compensates for the tendency of a small number of values to underestimate uncertainty (APHA, 1995).

It was determined that the standard deviation value was $\pm 3.1 \mathrm{mg} / \mathrm{L}$ and the $95 \%$ confidence interval was $\pm 3.5 \mathrm{mg} / \mathrm{L}$ of the mean value. Thus, if the difference in results falls within $\pm 7 \%$ of the mean value, the variation is considered to be statistical. 


\section{VITA AUCTORIS}

NAME

PLACE OF BIRTH

YEAR OF BIRTH

EDUCATION
Beatriz Carolina Polo-Christy

Mexico City, Mexico.

1972

Universidad Iberoamericana, Mexico City, Mexico

1990-1995 B.A.Sc. (Chemical Engineering) 